2014

\title{
Caddo Ceramic Vessels from Sites in the Upper Neches River Basin of East Texas, Anderson and Cherokee Counties, Texas
}

Timothy K. Perttula

Heritage Research Center, Stephen F. Austin State University

P. Shawn Marceaux

Bo Nelson

Mark Walters

Follow this and additional works at: https://scholarworks.sfasu.edu/ita

Part of the American Material Culture Commons, Archaeological Anthropology Commons, Environmental Studies Commons, Other American Studies Commons, Other Arts and Humanities Commons, Other History of Art, Architecture, and Archaeology Commons, and the United States History Commons

Tell us how this article helped you.

This Article is brought to you for free and open access by the Center for Regional Heritage Research at SFA ScholarWorks. It has been accepted for inclusion in Index of Texas Archaeology: Open Access Gray Literature from the Lone Star State by an authorized editor of SFA ScholarWorks. For more information, please contact cdsscholarworks@sfasu.edu. 


\section{Caddo Ceramic Vessels from Sites in the Upper Neches River Basin of East}

Texas, Anderson and Cherokee Counties, Texas

\section{Creative Commons License}

\section{(c) (1) \&}

This work is licensed under a Creative Commons Attribution-NonCommercial 4.0 International License 


\section{Caddo Ceramic Vessels from Sites in the Upper Neches River Basin of East Texas, Anderson and Cherokee Counties, Texas}

Timothy K. Perttula, P. Shawn Marceaux, Bo Nelson, and Mark Walters

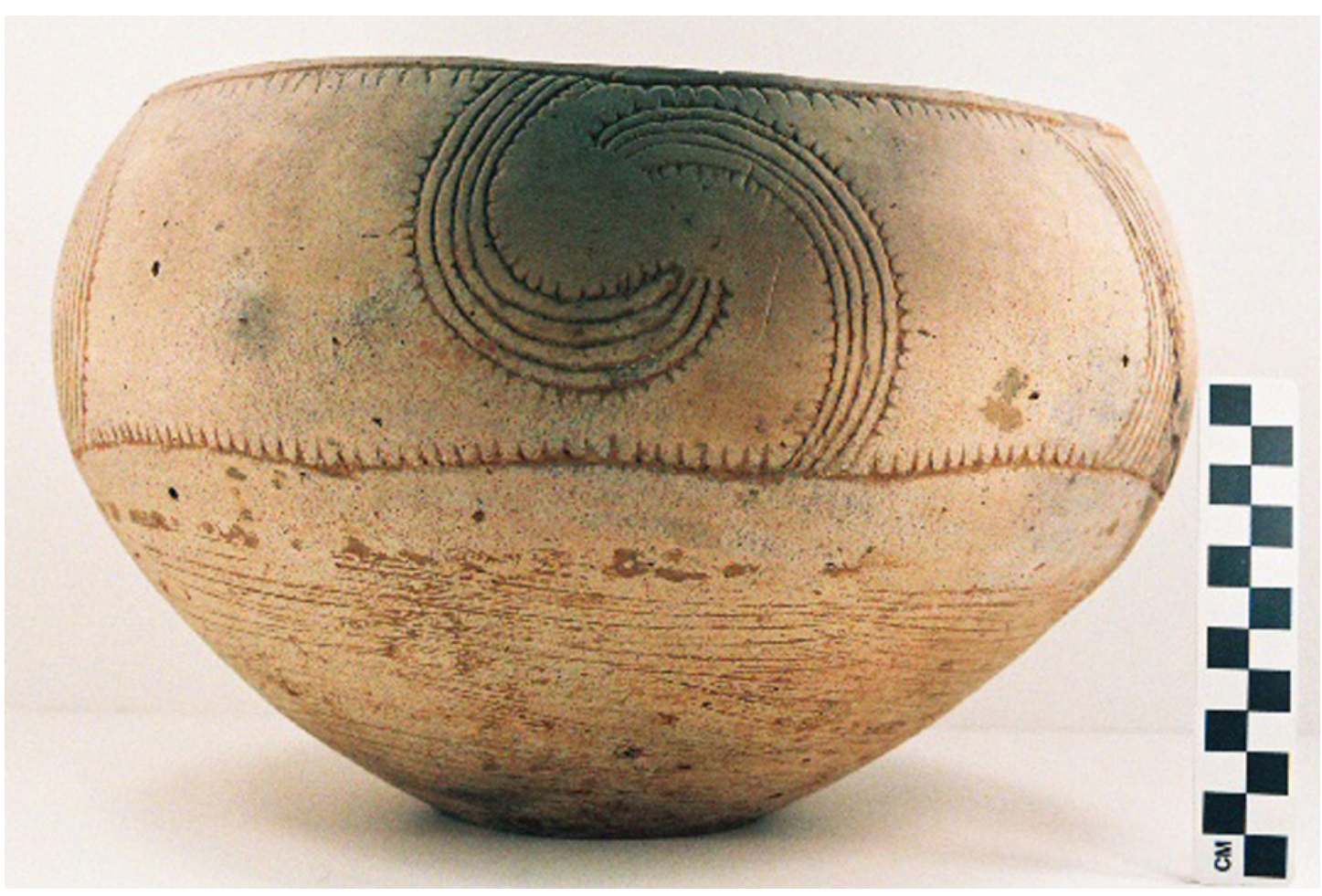

Special Publication No. 37

Friends of Northeast Texas Archaeology 
Distribution, Bo Nelson, 344 CR 4154

Pittsburg, Texas 75686

RBoNelson@aol.com

\begin{abstract}
Cover art:
Cover art: Patton Engraved, var. Patton carinated bowl from the Richard Patton site
\end{abstract}

Copyright (C) 2014, Friends of Northeast Texas Archaeology

(Austin and Pittsburg) 


\section{Table of Contents}

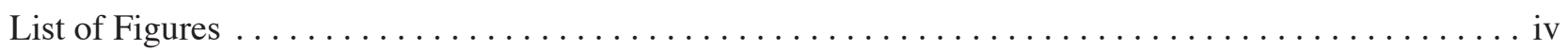

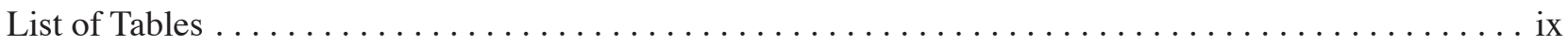

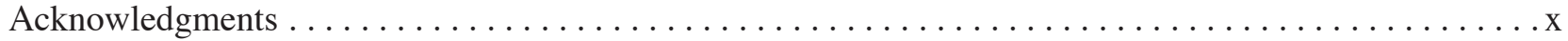

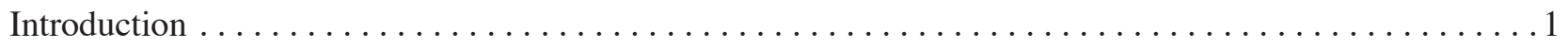

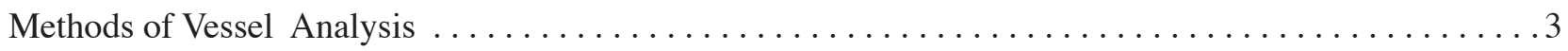

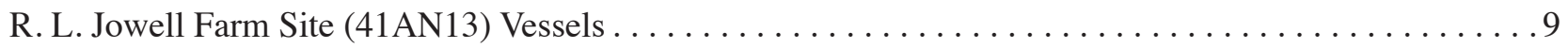

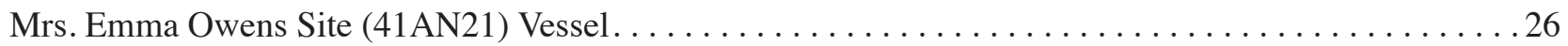

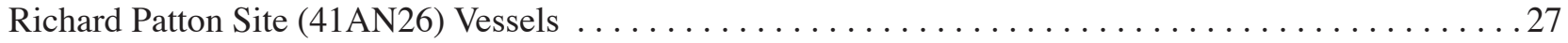

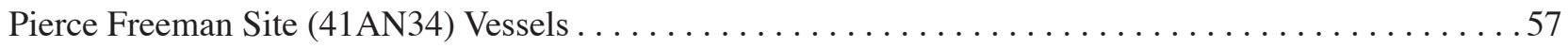

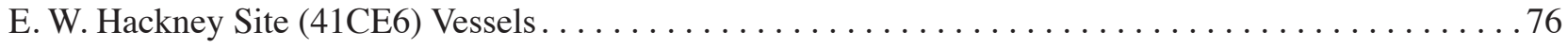

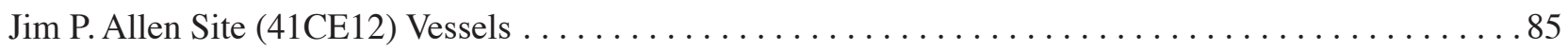

R. F. Wallace Site $(41 C E 20)$ Vessel . . . . . . . . . . . . . . . . . . . . . . . . . . . . . . . . . 140

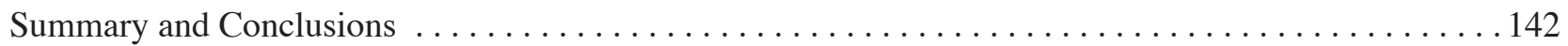

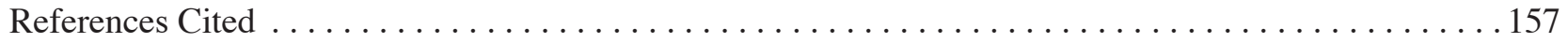




\section{List of Figures}

1. Historic Caddo sites in the southern part of East Texas, including sites discussed in this report.

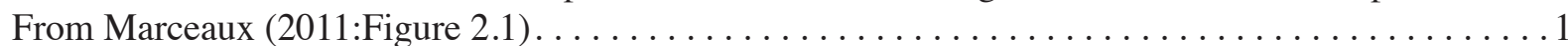

2. Locations of Historic Caddo sites along the upper Neches River basin. From Marceaux

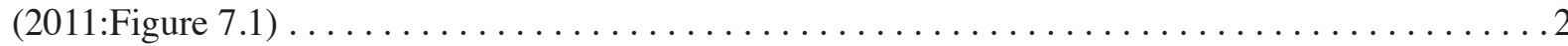

3. Varieties of Poynor Engraved: a-b', var. Blackburn; c-d, var. Cook; e, var. Hood; f-g', var. Lang; h-i, var. Freeman. After Perttula et al. (2011:Figure 6-64) . . . . . . . . . . . . . . . . .5

4. Regional varieties A-T of Poynor Engraved in the Upper Neches River basin. After

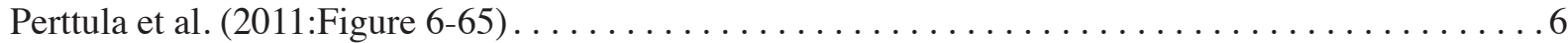

5. Varieties of Patton Engraved and Hume Engraved: a, Patton Engraved, var. Allen; b, Patton Engraved, var. Patton; c, Patton Engraved, var. Freeman; d, Patton Engraved, var. Fair; e, Hume Engraved, var. Hume; f, Hume Engraved, var. Allen; g, Hume

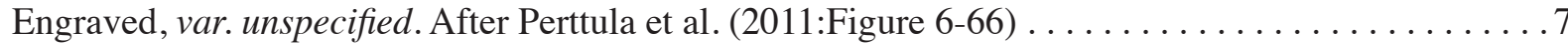

6. Distribution of varieties of Hood Engraved vessels in the Upper Neches River basin.

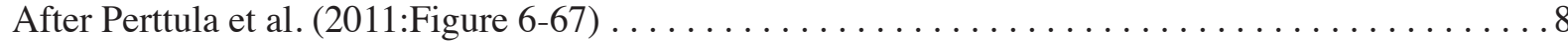

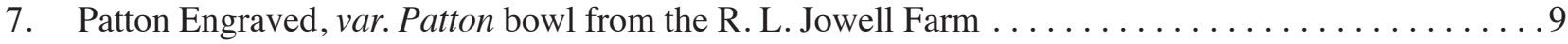

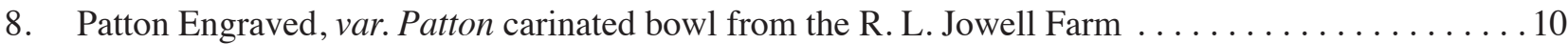

9. Patton Engraved, var. Patton carinated bowl from the R. L. Jowell Farm . . . . . . . . . . . . . 11

10. Cut-down carinated bowl with a brushed body from the R. L. Jowell site $\ldots \ldots \ldots \ldots \ldots \ldots \ldots$

11. Patton Engraved, var. Patton carinated bowl from the R. L. Jowell site . . . . . . . . . . . 13

12. Patton Engraved, var. Freeman carinated bowl from the R. L. Jowell site . . . . . . . . . . . 14

13. Patton Engraved, var. Patton carinated bowl from the R. L. Jowell farm site $\ldots \ldots \ldots \ldots \ldots$

14. cf. Patton Engraved, var. Freeman globular bowl from the R. L. Jowell site . . . . . . . . . . . 16

15. cf. Patton Engraved, var. Freeman globular bowl from the R. L. Jowell site . . . . . . . . . . 17

16. Unidentified engraved carinated bowl from the R. L. Jowell site $\ldots \ldots \ldots \ldots \ldots \ldots \ldots \ldots \ldots$

17. Cut-down Patton Engraved, var. Freeman carinated bowl from the R. L. Jowell site ........... 19

18. Poynor Engraved, var. Cook carinated bowl from the R. L. Jowell Farm site . . . . . . . . . . . . 20

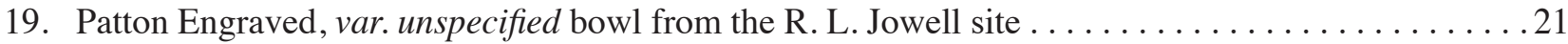

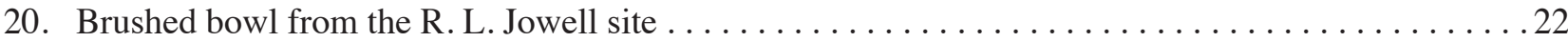

21. Probable Bullard Brushed jar body section from the R. L. Jowell site $\ldots \ldots \ldots \ldots \ldots \ldots \ldots \ldots$

22. Bullard Brushed jar from the R. L. Jowell Farm site . . . . . . . . . . . . . . . . . . . . . . . . 24

23. cf. Poynor Engraved, var. Freeman bowl from the Mrs. Emma Owens site . . . . . . . . . . 25

24. Patton Engraved, var. Patton carinated bowl from the Richard Patton site . . . . . . . . . 26

25. Patton Engraved, var. Patton carinated bowl from the Richard Patton site . . . . . . . . . ...27 
26. cf. Patton Engraved, var. Patton carinated bowl from the Richard Patton site . . . . . . . .. 28

27. Patton Engraved, var. Patton carinated bowl from the Richard Patton site . . . . . . . . . . . . . 29

28. Patton Engraved, var. unspecified carinated bowl from the Richard Patton site . . . . . . . . . . 30

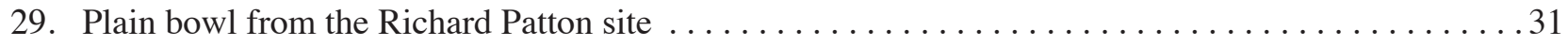

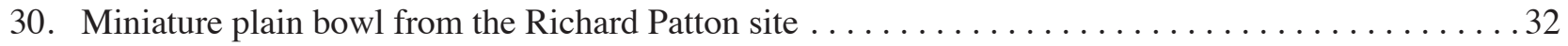

31. Patton Engraved, var. unspecified square bowl from the Richard Patton site $\ldots \ldots \ldots \ldots \ldots$

32. Patton Engraved, var. Freeman globular bowl from the Richard Patton site . . . . . . . . . 34

33. cf. Poynor Engraved, var. unspecified bottle from the Richard Patton site . . . . . . . . . . 35

34. Patton Engraved, var. Freeman globular bowl from the Richard Patton site $\ldots \ldots \ldots \ldots \ldots$

35. Poynor Engraved, var. Freeman globular bowl from the Richard Patton site . . . . . . . . . . . 37

36. Patton Engraved, var. Freeman globular bowl from the Richard Patton site . . . . . . . ... 38

37. Patton Engraved, var. Freeman globular bowl from the Richard Patton site . . . . . . . . . . . 39

38. Patton Engraved, var. Fair globular bowl from the Richard Patton site $\ldots \ldots \ldots \ldots \ldots \ldots \ldots 40$

39. cf. Patton Engraved, var. Freeman globular bowl from the Richard Patton site . . .......... 41

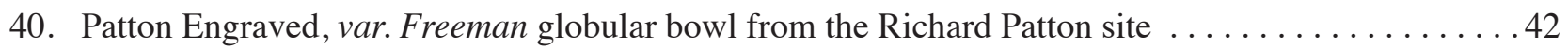

41. Patton Engraved, var. Freeman globular bowl from the Richard Patton site . . . . . . . . .. 43

42. Patton Engraved, var. Freeman globular bowl from the Richard Patton site . . . . . . . . . ...44

43. Patton Engraved, var. Allen globular bowl from the Richard Patton site . . . . . . . . . ...45

44. Patton Engraved, var. Allen globular bowl from the Richard Patton site $\ldots \ldots \ldots \ldots \ldots \ldots \ldots$

45. Patton Engraved, var. Allen globular bowl from the Richard Patton site $\ldots \ldots \ldots \ldots \ldots \ldots \ldots 4$

46. cf. Patton Engraved, var. Allen globular bowl from the Richard Patton site . . . . . . . . . . 48

47. cf. Patton Engraved, var. Fair globular bowl from the Richard Patton site . . . . . . . . . . . . . 49

48. Patton Incised bowl from the Richard Patton site: a, view of lug handles; b, side view . . . . . . . 50

49. Patton Engraved, var. Freeman globular bowl from the Richard Patton site . . . . . . . . ...51

50. Patton Engraved, var. Allen globular bowl from the Richard Patton site . . . . . . . . . ...52

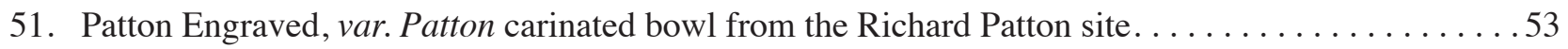

52. Poynor Engraved, var. Freeman globular bowl from the Richard Patton site . . . . . . . . . . . 54

53. Hume Engraved, var. Hume bottle from the Pierce Freeman site $\ldots \ldots \ldots \ldots \ldots \ldots \ldots \ldots \ldots$

54. Bullard Brushed jar from the Pierce Freeman site $\ldots \ldots \ldots \ldots \ldots \ldots \ldots \ldots \ldots \ldots \ldots \ldots \ldots \ldots \ldots \ldots \ldots \ldots \ldots$

55. Poynor Engraved, var. $N$ carinated bowl from the Pierce Freeman site $\ldots \ldots \ldots \ldots \ldots \ldots \ldots 57$

56. Poynor Engraved, var. Hood globular bowl from the Pierce Freeman site . . . . . . . . . . . . 58

57. Poynor Engraved, var. Hood carinated bowl from the Pierce Freeman site . . . . . . . . . . . . 59

58. Poynor Engraved, var. unspecified globular bowl from the Pierce Freeman site . . . . . . . . . 60 
59. Poynor Engraved, var. Freeman globular bowl from the Pierce Freeman site . . . . . . . . . 61

60. Plain miniature globular bowl from the Pierce Freeman site $\ldots \ldots \ldots \ldots \ldots \ldots \ldots \ldots \ldots \ldots \ldots \ldots \ldots \ldots \ldots$

61. Poynor Engraved, var. Freeman globular bowl from the Pierce Freeman site . . . . . . . . . . 63

62. Poynor Engraved, var. Freeman globular bowl from the Pierce Freeman site . . . . . . . . . . . . 64

63. Hood Engraved, var. Allen effigy bowl: a, side view; b, view looking towards the quadruped . . . . 665

64. Poynor Engraved, var. Cook carinated bowl from the Pierce Freeman site $\ldots \ldots \ldots \ldots \ldots$

65. Poynor Engraved, var. Hood globular bowl from the Pierce Freeman site . . . . . . . . . . 67

66. Poynor Engraved, var. Freeman globular bowl from the Pierce Freeman site . . . . . . . . . . 68

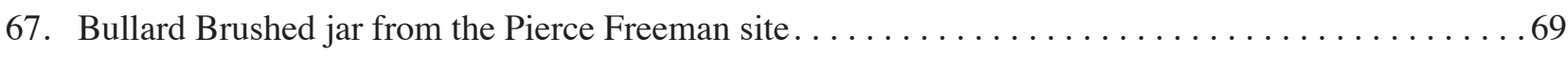

68. Poynor Engraved, var. Freeman globular bowl from the Pierce Freeman site . . . . . . . . . . . 70

69. Patton Engraved, var. Patton carinated bowl from the Pierce Freeman site $\ldots \ldots \ldots \ldots \ldots \ldots 71$

70. cf. Poynor Engraved, var. Freeman globular bowl from the Pierce Freeman site . . . . . . . . . . 72

71. Poynor Engraved, var. Freeman globular bowl from the Pierce Freeman site . . . . . . . . . 73

72. Patton Engraved, var. Fair globular bowl from the E. W. Hackney site . . . . . . . . . . . 74

73. Patton Engraved, var. Patton carinated bowl from the E. W. Hackney site . . . . . . . . . . 75

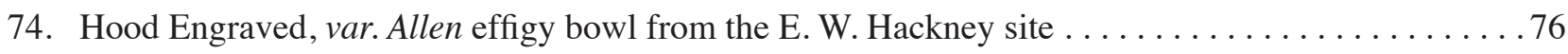

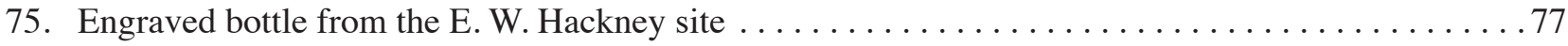

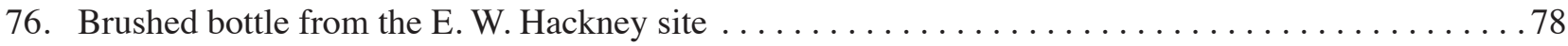

77. cf. Poynor Engraved, var. Freeman globular bowl from the E. W. Hackney site . . . . . . . . . . . 79

78. Hodges Engraved bottle from the E. W. Hackney site $\ldots \ldots \ldots \ldots \ldots \ldots \ldots \ldots \ldots \ldots \ldots \ldots \ldots \ldots \ldots \ldots \ldots$

79. Patton Engraved, var. Freeman or var. Fair vessel from the E. W. Hackney site . . . . . . . . . 81

80. Bullard Brushed jar section from the Jim P. Allen site $\ldots \ldots \ldots \ldots \ldots \ldots \ldots \ldots \ldots \ldots \ldots \ldots \ldots \ldots \ldots$

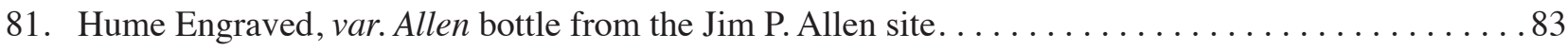

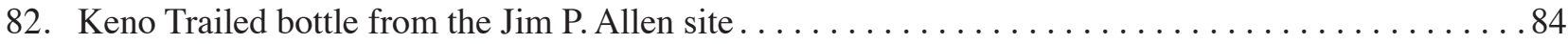

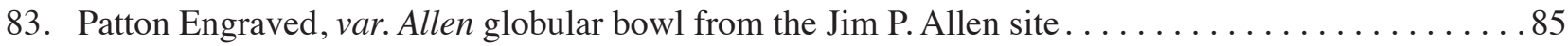

84. Poynor Engraved, var. Blackburn carinated bowl from the Jim P. Allen site $\ldots \ldots \ldots \ldots \ldots$

85. cf. Poynor Engraved, var. Freeman globular bowl from the Jim P. Allen site . . . . . . . . . . 87

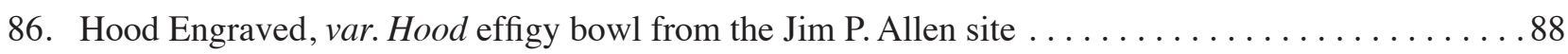

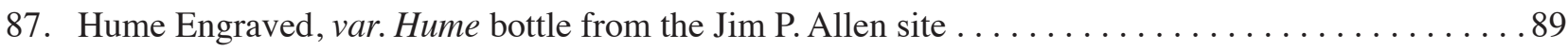

88. Hume Engraved, var. unspecified bottle from the Jim P. Allen site . . . . . . . . . . . . . . 90

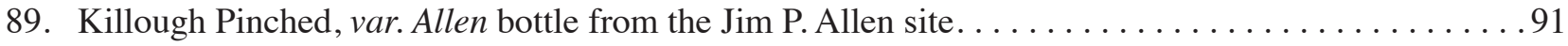

90. Poynor Engraved, var. Freeman globular bowl from the Jim P. Allen site . . . . . . . . . . . . 92

91. Poynor Engraved, var. Freeman conjoined globular bowls from the Jim P. Allen site . . . . . . . .93 
92. Patton Engraved, var. Allen globular bowl from the Jim P. Allen site . . . . . . . . . . . . 94

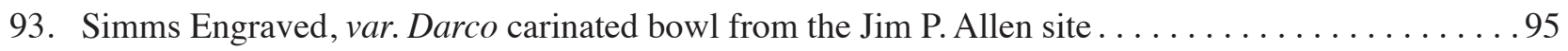

94. Unidentified engraved globular bowl, possibly Poynor Engraved, var. B, from the

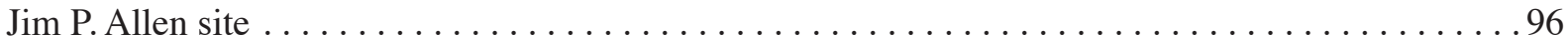

95. cf. Avery Engraved deep bowl from the Jim P. Allen site $\ldots \ldots \ldots \ldots \ldots \ldots \ldots \ldots \ldots \ldots \ldots$

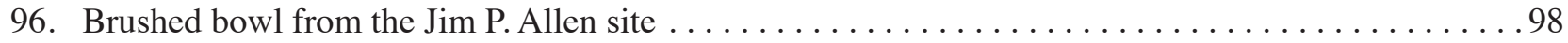

97. Patton Engraved, var. unspecified carinated bowl from the Jim P. Allen site . . . . . . . . . . . 99

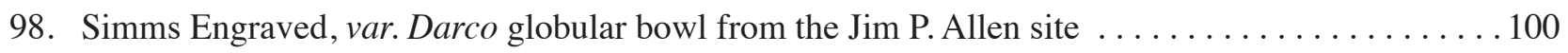

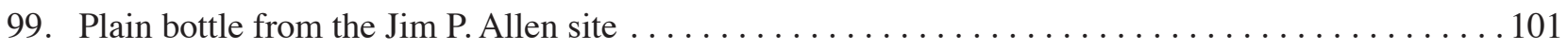

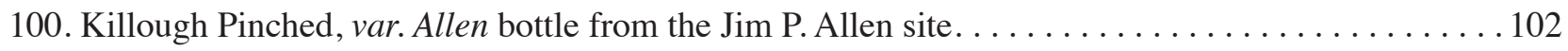

101. Brushed vessel body section to a carinated bowl or large bowl of an unidentified ceramic type . . . 103

102. cf. Hume Engraved, var. unspecified bottle from the Jim P. Allen site . . . . . . . . . . . . . 104

103. Simms Engraved, var. Darco carinated bowl from the Jim P. Allen site . . . . . . . . . . . 105

104. cf. Patton Engraved, var. Fair globular bowl from the Jim P. Allen site . . . . . . . . . . . . . 106

105. Patton Engraved, var. Allen globular bowl from the Jim P. Allen site . . . . . . . . . . . . . 107

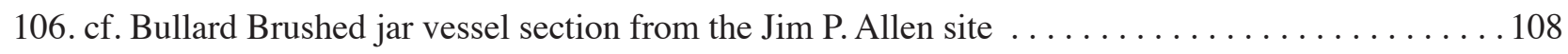

107. Hume Engraved, var. unspecified bottle section from the Jim P. Allen site . . . . . . . . . . . . 109

108. cf. Patton Engraved, var. Freeman globular bowl from the Jim P. Allen site . . . . . . . . . 110

109. Hume Engraved, var. unspecified bottle from the Jim P. Allen site . . . . . . . . . . . . 111

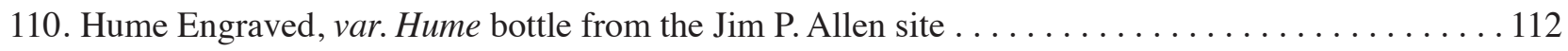

111. Hood Engraved, var. Allen effigy bowl from the Jim P. Allen site: a, side view;

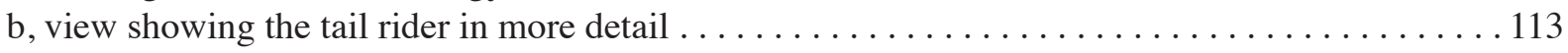

112. cf. Poynor Engraved, var. Freeman globular bowl from the Jim P. Allen site . . . . . . . . . 114

113. Patton Engraved, var. Allen globular bowl from the Jim P. Allen site . . . . . . . . . . . . 115

114. Poynor Engraved, var. Blackburn carinated bowl from the Jim P. Allen site . . . . . . . . . 116

115. Bullard Brushed jar section from the Jim P. Allen site $\ldots \ldots \ldots \ldots \ldots \ldots \ldots \ldots \ldots \ldots \ldots \ldots$

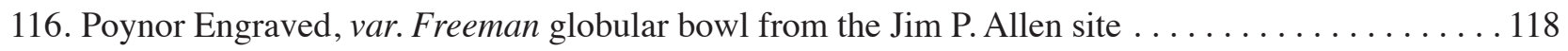

117. Hood Engraved, var. Allen effigy bowl from the Jim P. Allen site . . . . . . . . . . . . . 119

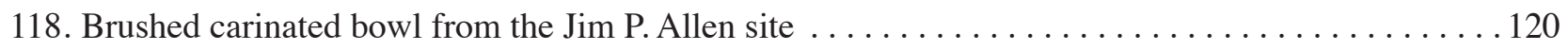

119. Poynor Engraved, var. Freeman globular bowl from the Jim P. Allen site . . . . . . . . . . 121

120. Poynor Engraved, var. Freeman globular bowl from the Jim P. Allen site . . . . . . . . . . 122

121. Hood Engraved, var. Allen effigy bowl from the Jim P. Allen site . . . . . . . . . . . . 123

122. Simms Engraved carinated bowl from the Jim P. Allen site . . . . . . . . . . . . . . . 124

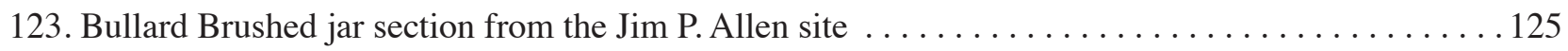




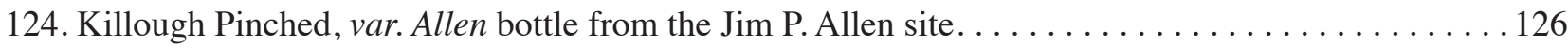

125. Hume Engraved, var. unspecified bottle from the Jim P. Allen site . . . . . . . . . . . . 127

126. Patton Engraved, var. Patton carinated bowl from the Jim P. Allen site . . . . . . . . . . . 128

127. Patton Engraved, var. Freeman globular bowl from the Jim P. Allen site . . . . . . . . . . . . 129

128. Poynor Engraved, var. Freeman globular bowl from the Jim P. Allen site . . . . . . . . . . 130

129. Patton Engraved, var. unspecified globular bowl from the Jim P. Allen site . . . . . . . . . . 131

130. Patton Engraved, var. unspecified globular bowl from the Jim P. Allen site . . . . . . . . . . 132

131. Poynor Engraved, var. Hood globular bowl from the Jim P. Allen site . . . . . . . . . . . . 133

132. Hume Engraved, var. unspecified bottle from the Jim P. Allen site . . . . . . . . . . . 134

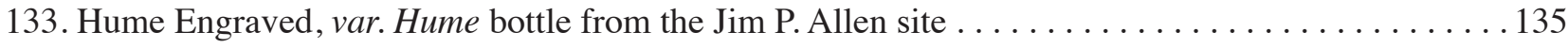

134. Patton Engraved, var. unspecified globular bowl from the Jim P. Allen site . . . . . . . . . . . 136

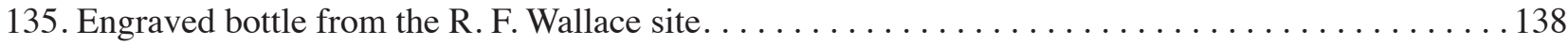

136. Late and Historic Caddo ceramic traditions in East Texas, south and west of the Sabine River. Upper Neches Frankston and Allen phases shown in brown, and bone-tempered brushed tradition shown in green (from Perttula et al. 2011:Figure 6-71) . . . . . 140

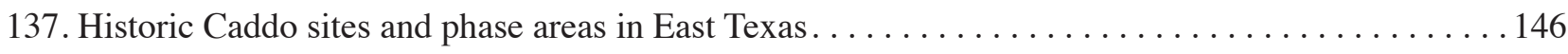




\section{List of Tables}

1. Vessel forms represented in these upper Neches River basin assemblages . . . . . . . . . . . . 141

2. Vessel size (in liters) in these upper Neches River basin assemblages . . . . . . . . . . . . 142

3. Ceramic types and varieties in these upper Neches River basin assemblages. . . . . . . . . . . . 143

4. Use of pigments on fine ware vessels in these upper Neches River basin assemblages . . . . . . . . 145

5. Temper and paste in the vessels in these upper Neches River basin assemblages. . . . . . . . . . 148

6. Firing conditions of the vessels in these upper Neches River basin assemblages . . . . . . . . . . . 149

7. Pinkware vessels in these upper Neches River basin assemblages . . . . . . . . . . . . 150

8. Pinkware vessels from other Caddo sites in the upper Neches River basin $\ldots \ldots \ldots \ldots \ldots \ldots 1$ 


\section{Acknowledgments}

We would like to first thank the Caddo Nation of Oklahoma, especially Robert Cast, Tribal Historic Preservation Officer, for permission to document these vessels in the Texas Archeological Research Laboratory (TARL) collections. We also thank personnel at TARL for facilitating the documentation and study of the vessels, notably Laura Nightengale, then Head of Collections, and Dr. Darrell G. Creel, then Director at TARL. 


\section{Introduction}

This report concerns the analysis and documentation of 129 ancestral Caddo ceramic vessels from seven burial/cemetery sites in the upper Neches River basin in East Texas: R. L. Jowell (41AN13, n=13 vessels), Mrs. Emma Owens (41AN21, n=1 vessel), Richard Patton (41AN26, n=29 vessels), Pierce Freeman (41AN34, n=19 vessels), E. W. Hackney (41CE6, n=8 vessels), Jim P. Allen (41CE12, n=55 vessels), and R. F. Wallace (41CE20, $n=1$ vessel). These sites are part of a cluster of Late Caddo and Historic Caddo period sites in northeastern Anderson County and northwestern Cherokee County (Figures 1 and 2).

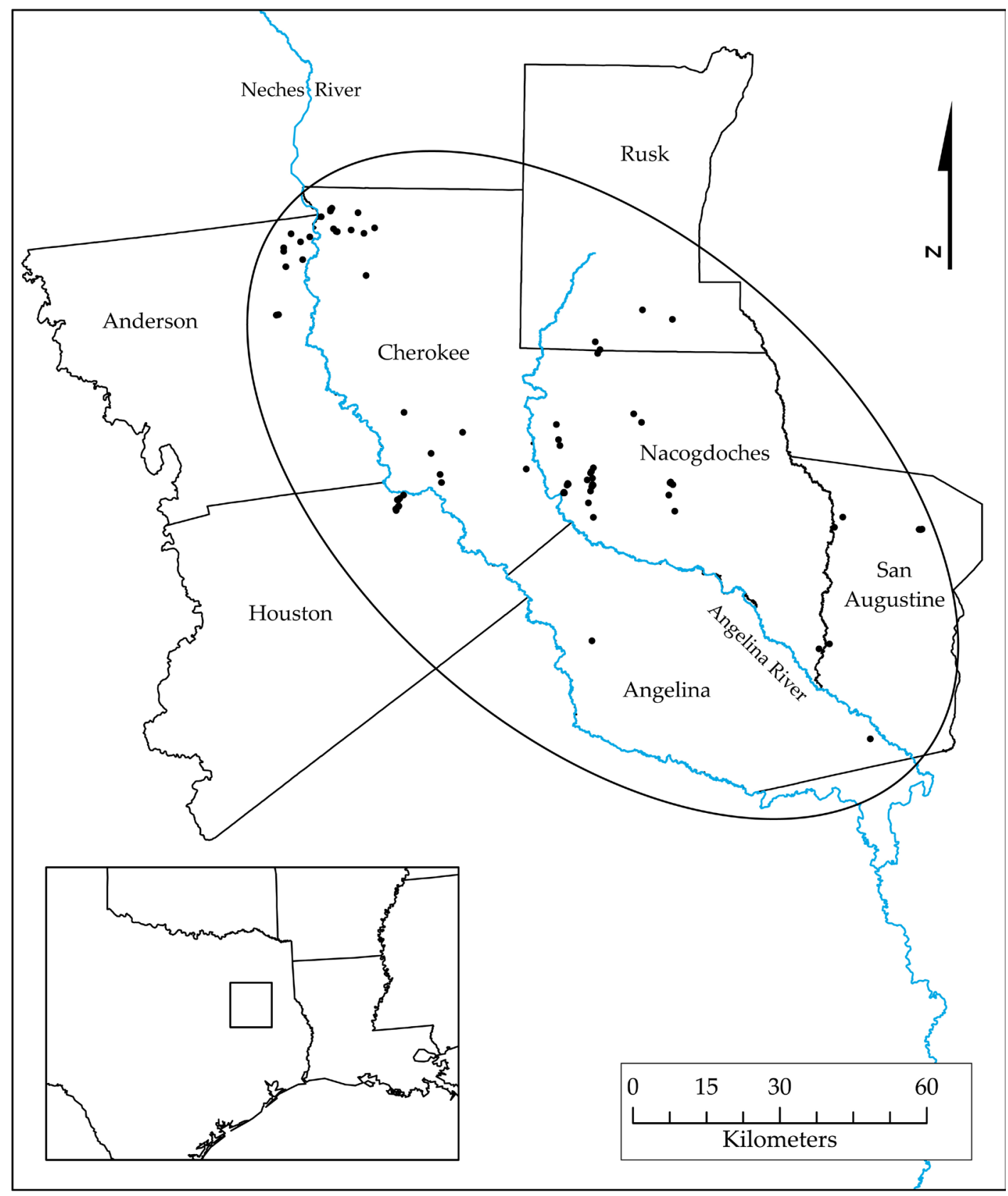

Figure 1. Historic Caddo sites in the southern part of East Texas, including sites discussed in this report. From Marceaux (2011:Figure 2.1). 


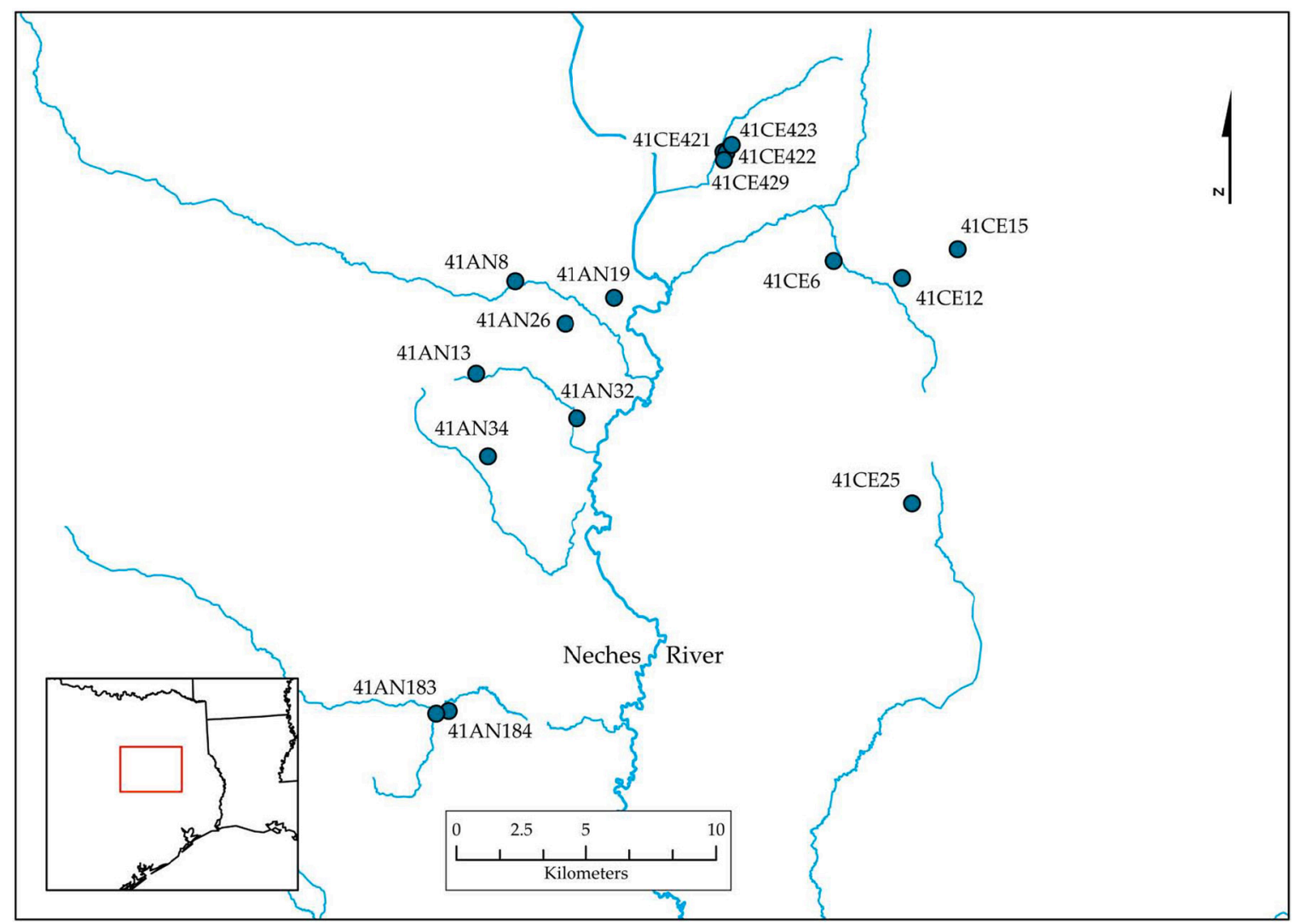

Figure 2. Locations of Historic Caddo sites along the upper Neches River basin. From Marceaux (2011:Figure 7.1).

These vessels are in the collections at the Texas Archeological Research Laboratory at The University of Texas at Austin. They were analyzed and documented in 2008 as part of the study of the material culture of the Hasinai Caddo groups of East Texas for Marceaux's 2011 Ph.D. dissertation at The University of Texas. Although images of the vessels were provided in Marceaux (2011:531-609), and the overall findings of the analysis were discussed in broad terms, the primary data gathered in the vessel analysis is provided here for the first time. The concluding section of the report provides a summary of the characteristics of the fine ware and utility ware vessels from burial contexts at the seven sites - which are thought to pertain primarily to Historic Caddo Allen phase burial features at the different sites; several of the sites have associated European trade goods - along with a consideration of the overall nature of post $17^{\text {th }}$ century Caddo ceramic vessel technology and style among upper Neches Caddo communities. 


\section{Methods of Vessel Analysis}

As with other ancestral Caddo ceramic vessel documentation studies recently completed of East Texas ceramic assemblages (cf. Perttula et al. 2011:219-223; Perttula et al. 2013), the following consistent set of attributes were employed in this ceramic vessel study:

Non-plastics: Deliberate and indeterminate materials in the paste (Rice 1987:411), including a variety of tempers (grog or crushed sherds, bone, hematite/ferruginous sandstone, shell, quartz sands, etc.) and "particulate matter of some size." The grog, bone, and hematite/ferruginous sandstone non-plastics appear to have been deliberately added to the paste as tempers. The bone used for temper had been burned and calcined, then crushed, before it was added to the paste.

Vessel Form: Vessel form categories include open containers (bowls of several sizes, including effigy bowls, carinated bowls, and compound bowls) and restricted containers, including jars and bottles, as well as plates. As restricted containers, jars allow access by hand, but bottles do not (Brown 1996:335). Other form attributes that were recorded include the rim profile (outflaring or everted, vertical or standing, and inverted), lip profile (rolled to the exterior, rounded, flat, or thinned), and base shape (flat or rounded).

Core Colors: Observations on ceramic cross-section colors permit consideration of oxidation patterns (Teltser 1993:Figure 2A-H), and thus the conditions under which the vessel was fired and then cooled after firing. Comments are included for these attributes on the presence and location of fire-clouding, sooting or smudging from cooking use (Skibo 1992), and the preservation of any charred organic remains.

Wall Thickness: Thickness was recorded in millimeters, using a vernier caliper, at the lip, along the rim, at several points along the body, and at the base when possible (only for the vessels that were not complete).

Interior and Exterior Surface Treatment: The primary methods of finishing the surface of the vessels includes either smoothing, burnishing, and polishing (Rice 1987:138). Brushing, while a popular method of roughening the surface (particularly the body) of large and small Middle (ca. A.D. 1200-1450) and Late Caddo (ca. A.D. 1450-1680) period cooking jars in several parts of the Caddo area, is here considered a decorative treatment rather than solely a functional surface treatment (cf. Rice 1987:138), although not all Caddo ceramic analysts treat brushing as a decorative treatment (cf. Gadus et al. 2006:31). Smoothing creates "a finer and more regular surface... [and] has a matte rather than a lustrous finish" (Rice 1987:138). Burnishing, on the other hand, creates an irregular lustrous finish marked by parallel facets left by the burnishing tool (perhaps a pebble or bone). A polished surface treatment is marked by a uniform and highly lustrous surface finish, done when the vessel is dry, but without "the pronounced parallel facets produced by burnishing leather-hard clay" (Rice 1987:138).

The application of a hematite-rich clay slip (Ferring and Perttula 1987), either red or black after firing in an oxidizing or reducing (i.e., low-oxygen) environment, is another form of surface treatment noted in many East Texas assemblage. On these vessels, the clay slip is more frequently applied on the vessel exterior, or on both surfaces, than on the interior surface, and then was either burnished or polished after it was leatherhard or dry. None of these Upper Neches River basin vessels have a slipped decoration, however.

Height and Orifice Diameter: These attributes, measured in centimeters, were recorded with a ruler.

Diameter at Bottom of Rim and Base Diameter: Also recorded in millimeters using a ruler, these attributes permit characterization of the overall contour and shape of the vessel. 
Volume: With measurements of height and orifice diameter obtained from the vessels, as well as other measurements of size (i.e., base diameter and maximum body width), volumes were estimated by comparison with known vessel volumes of specific forms (i.e., carinated bowl, jar, bottle, compound bowl, and bowl) in other recently documented Caddo vessel assemblages.

Base Diameter and Shape: these attributes were either measured in centimeters or by shape attributes: circular or square, and flat or round.

Decoration: Decorative techniques present in these Upper Neches River basin vessel collection from sites in East Texas include engraving, incising, trailing, punctating, pinching, brushing, and appliquéing, and on certain vessels, combinations of decorative techniques (i.e., brushed-punctated) created the decorative elements and motifs. Engraving was done with a sharp tool when the vessel was either leather-hard, or after it was fired, as were the tick marks often seen on vessels in this collection, while the other decorative techniques were executed with tools (trailing, incising, and punctation), by adding strips of clay to the wet body (appliqué), using frayed sticks or grass stems (brushing) dragged across the body surface, or fingernails (certain forms of punctations and pinching), when the vessel was wet or still plastic. Excising is considered a form of engraved decoration, where the clay is deliberately and closely marked/scraped and carved away with a sharp tool, usually to create triangular elements, tick marks, or excised punctations.

Use of Pigments: Another form of vessel decoration is the use of red (hematite or ochre) or white (kaolin clay) clay pigments that have been smeared or rubbed into the engraved lines of certain vessels.

Type: The kinds of ceramic types and defined varieties in the collections from East Texas sites follow Suhm and Jelks (1962), Kleinschmidt (1982), Perttula (2008), and Perttula et al. (2011). Of particular concern are recently defined varieties of Poynor Engraved (Figures 3-4), Patton Engraved (Figure 5), Hume Engraved (Figure 5), and Hood Engraved (Perttula et al. 2011:271). Hood Engraved is a distinctive effigy bowl form found in Late Caddo and Historic Caddo cemeteries in the upper Neches River basin (Figure 6). 


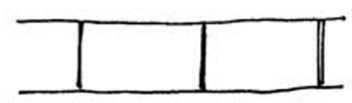

a
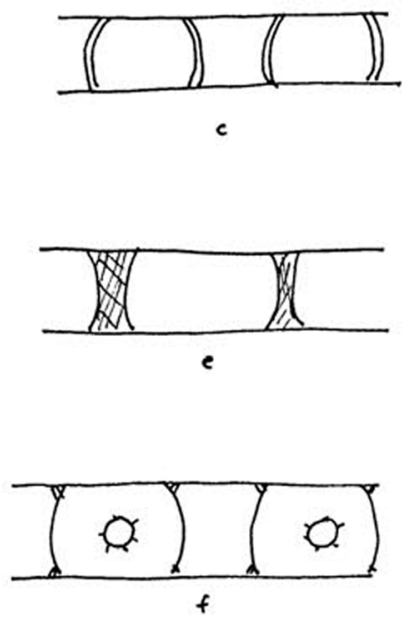

$f$

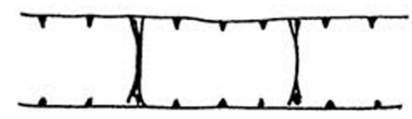

h
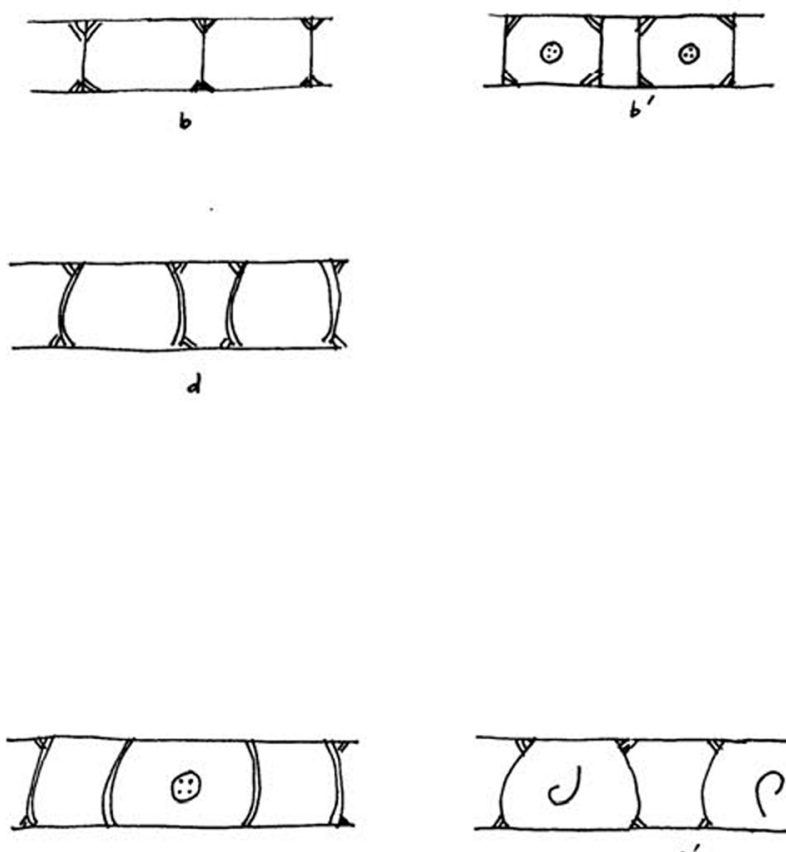

g
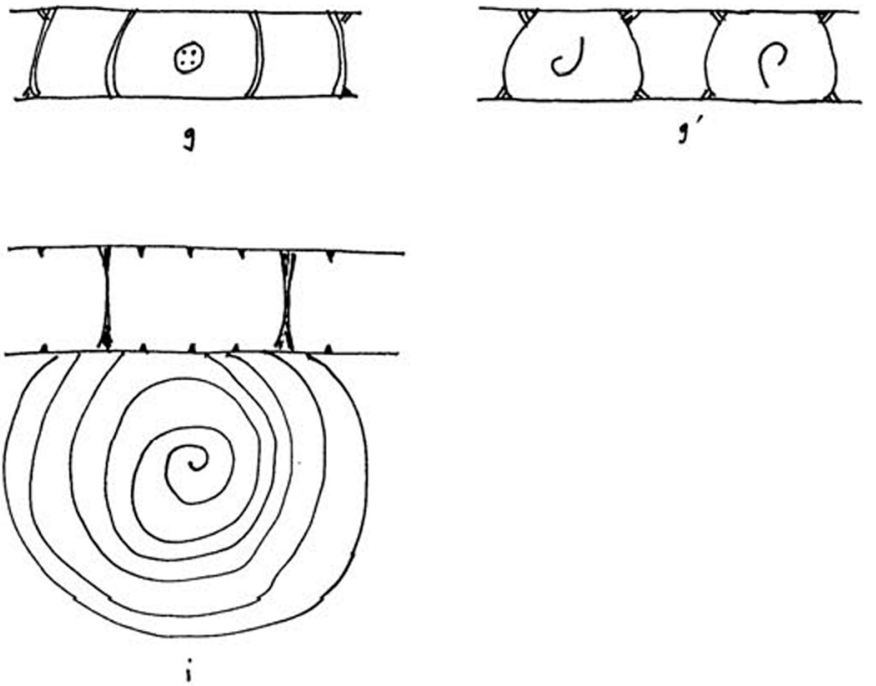

Figure 3. Varieties of Poynor Engraved: a-b', var. Blackburn; c-d, var. Cook; e, var. Hood; f-g', var. Lang; h-i, var. Freeman. After Perttula et al. (2011:Figure 6-64). 


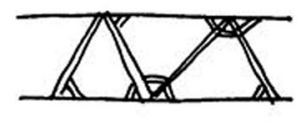

Var. A, Nerted triangle

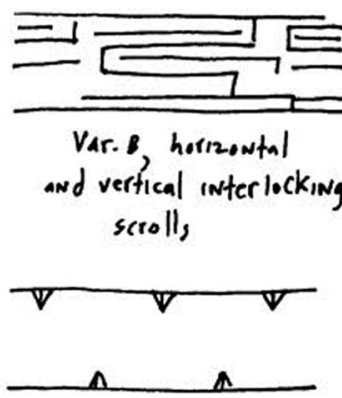

Var. C, continuovs

hatched triangles

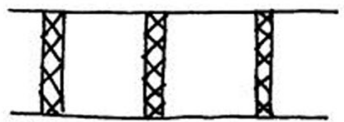

Var. D, vertical

cross-hatched panel,

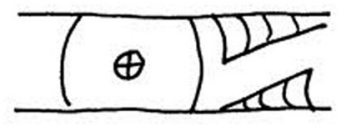

Var. E, scroll and circle

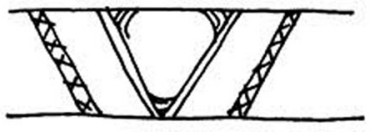

var. F, Nested ovals and

diagowal cross-hatched ladders

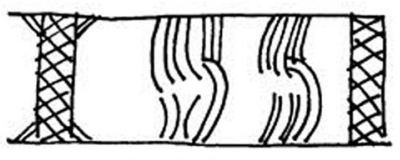

var. $G$, hooked arm scroll and cross-hatched panels

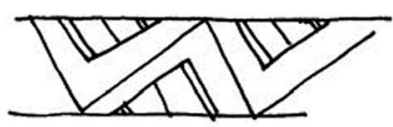

Var. I, curtinuovs

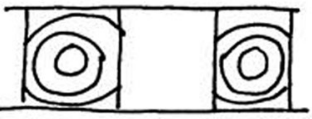

var. $J$, rectangular panel and nested circle

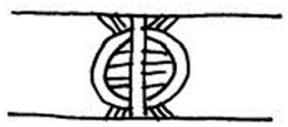

var. $K$ semi-circle and nested circles

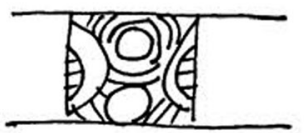

Var. L, rectangular panel and negative cirele

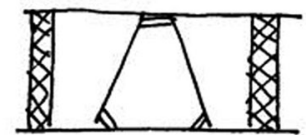

var. $M$, triangle and cross-hatched panel

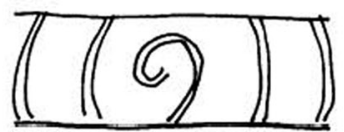

var, $N$ hooked arm and oval

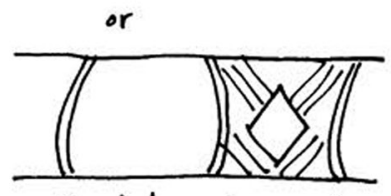

oval and diamowd, Var. $N^{\prime}$

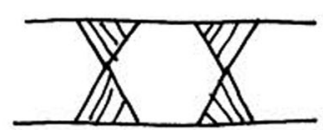

Var. 0, stacked

hatched triangles
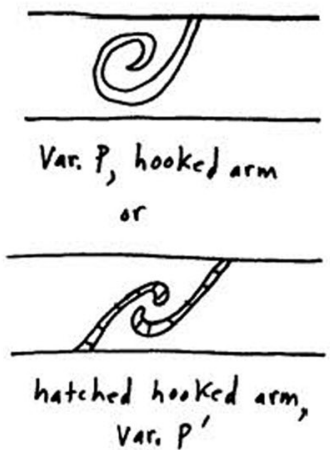

var. $P$

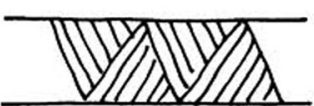

Var. $Q$, hatched Nested triangles

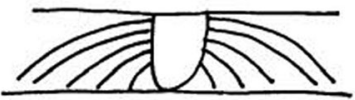

Var. $R$, concentric semi-circle

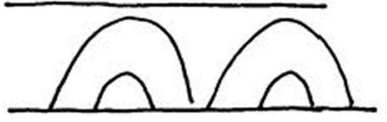

Var. S, concentric oval

or
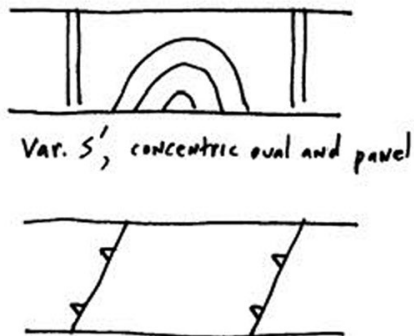

Var. $T$, diagewal with

small pendant triangle

Figure 4. Regional varieties A-T of Poynor Engraved in the Upper Neches River basin. After Perttula et al. (2011:Figure 6-65). 

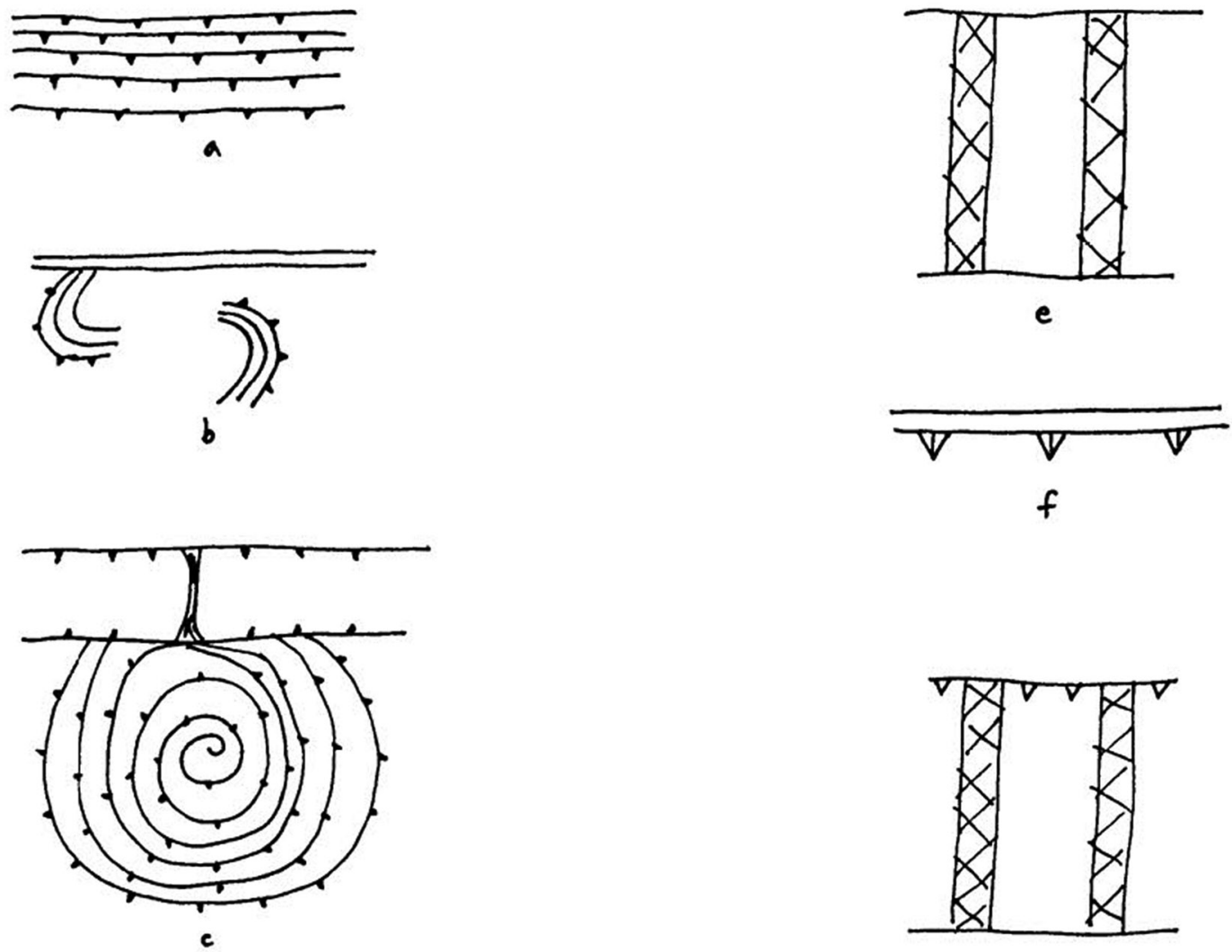

9
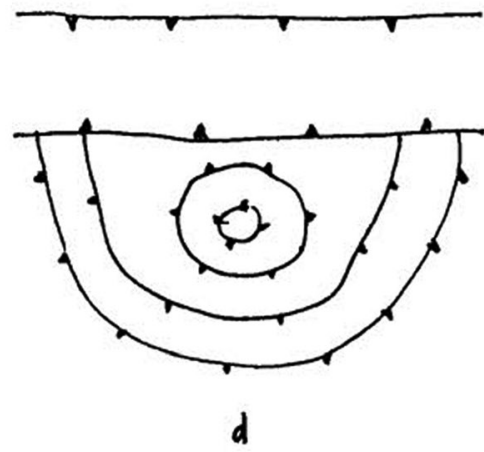

Figure 5. Varieties of Patton Engraved and Hume Engraved: a, Patton Engraved, var. Allen; b, Patton Engraved, var. Patton; c, Patton Engraved, var. Freeman; d, Patton Engraved, var. Fair; e, Hume Engraved, var. Hume; f, Hume Engraved, var. Allen; g, Hume Engraved, var. unspecified. After Perttula et al. (2011:Figure 6-66). 


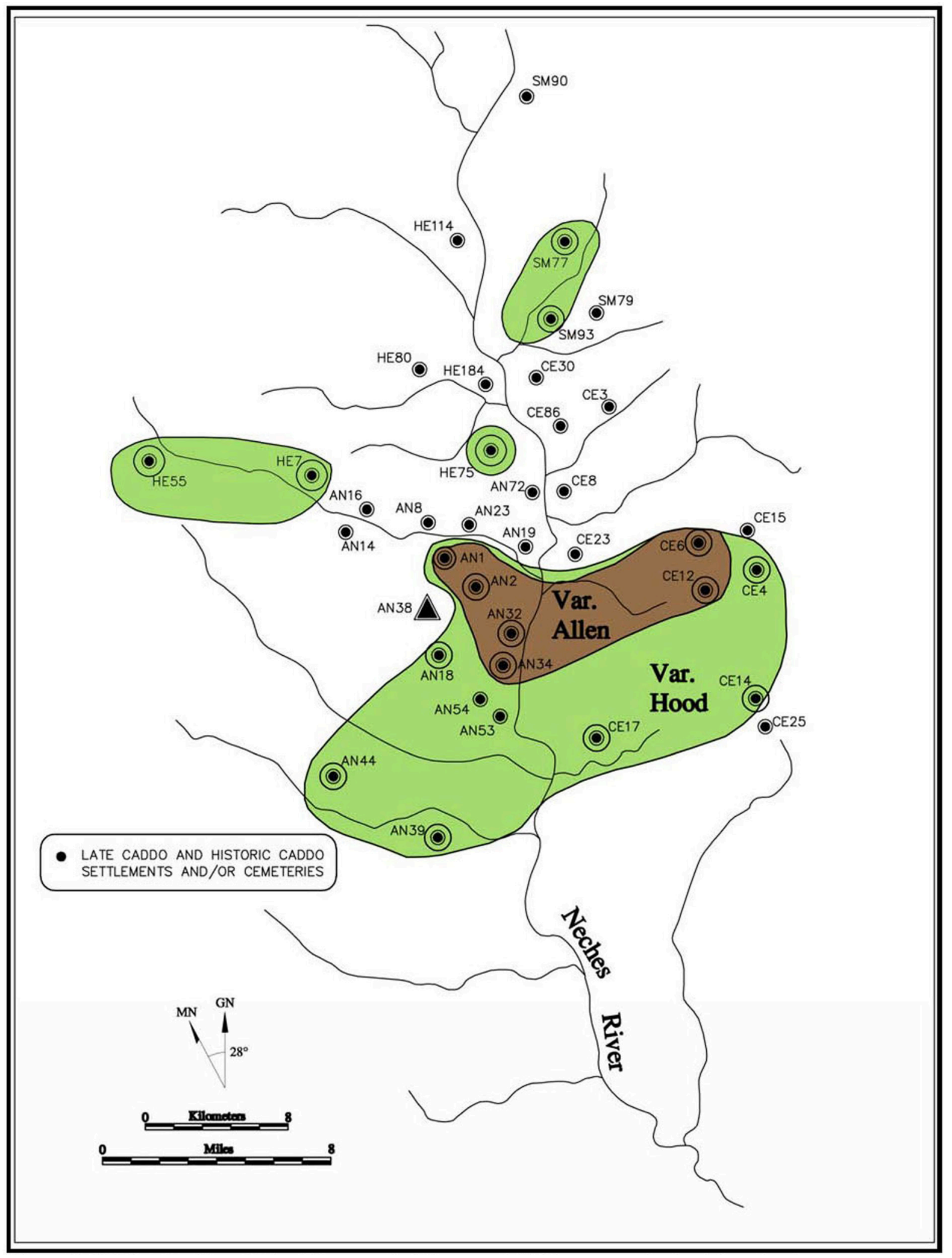

Figure 6. Distribution of varieties of Hood Engraved vessels in the Upper Neches River basin. After Perttula et al. (2011:Figure 6-67). 


\section{R. L. Jowell Farm Site (41AN13) Vessels}

The R. L. Jowell Farm site is located on Kickapoo Creek, an eastward-flowing tributary of the Neches River, a few km south of Frankston, Texas. The vessels in the collection were dug up by the landowner, and the University of Texas purchased the vessels and other artifacts in 1933 (Cole 1975:110; Marceaux 2011:415). European trade goods, including 10 glass beads and a metal knife, were among the funerary objects in the burials, along with Jowell knives and several arrow points. The metal knife was found inside Vessel 41AN13-1, and the glass beads may have been inside Vessel 41AN13-9 (Cole 1975:111).

SITE NAME OR SITE NUMBER: R. L. Jowell Farm

VESSEL NO.: 41AN13-X1

NON-PLASTICS AND PASTE: grog

VESSEL FORM: Bowl

RIM AND LIP FORM: Inverted rim and rounded lip

CORE COLOR: A (fired and cooled in an oxidizing environment)

INTERIOR SURFACE COLOR: light brownishgray; fire clouds on the base

EXTERIOR SURFACE COLOR: very pale brown; fire clouds on the rim and body

WALL THICKNESS (RIM, BODY, AND BASE IN MM): rim, $5.1 \mathrm{~mm}$; body, $6.0 \mathrm{~mm}$

INTERIOR SURFACE TREATMENT: smoothed on the body

EXTERIOR SURFACE TREATMENT: smoothed on the body

HEIGHT (IN CM): 20.0

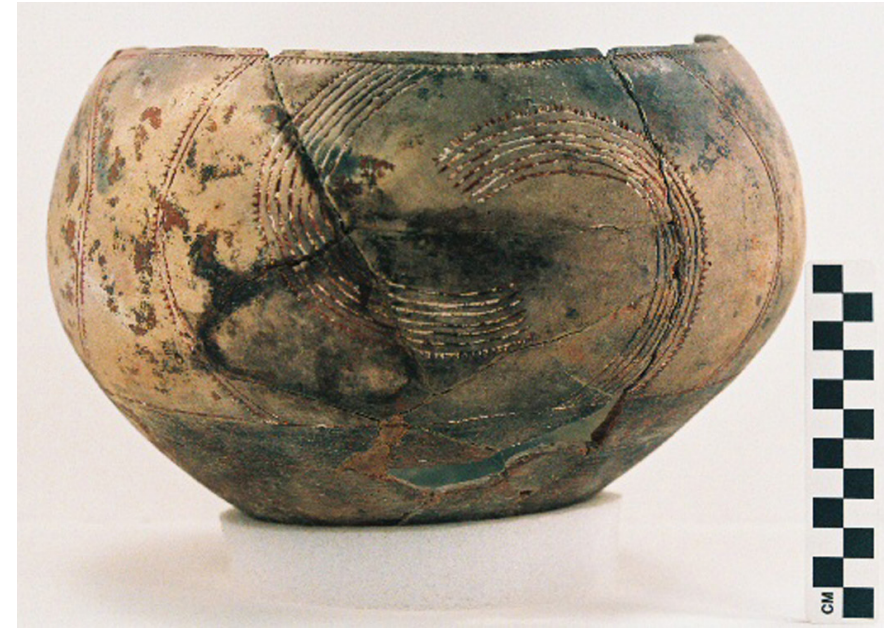

Figure 7. Patton Engraved, var. Patton bowl from the R. L. Jowell Farm.

ORIFICE DIAMETER (IN CM): 23.0

DIAMETER AT BOTTOM OF RIM OR NECK (IN CM): $29.5 \mathrm{~cm}$ at the widest part of the body

BASE DIAMETER (IN CM) AND SHAPE OF BASE: 7.0; flat and circular

ESTIMATED VOLUME (IN LITERS): 3.7

DECORATION (INCLUDING MOTIF AND ELEMENTS WHEN APPARENT): The rim panel is defined by single upper and lower horizontal engraved lines; the upper line has downward-pointing tick marks. On 
the panel are four sets of closely-spaced upper and lower vertical to curvilinear engraved lines, the outer line of which has outward-pointing tick marks. These sets of vertical to curvilinear engraved lines are divided by open engraved brackets with inward-pointing tick marks on both sides of the bracket (Figure 7). The vessel body has horizontal and diagonal brushing marks.

PIGMENT USE AND LOCATION ON VESSEL: white pigment in engraved lines

TYPE AND VARIETY [IF KNOWN]: Patton Engraved, var. Patton

SITE NAME OR SITE NUMBER: R. L. Jowell Farm

VESSEL NO.: 41AN13-1

NON-PLASTICS AND PASTE: grog

VESSEL FORM: Carinated bowl

RIM AND LIP FORM: Inverted rim and rounded lip

CORE COLOR: F (fired in a reducing environment and cooled in the open air)

INTERIOR SURFACE COLOR: very pale brown; fire clouding

EXTERIOR SURFACE COLOR: light brown; fire clouding

WALL THICKNESS (RIM, BODY, AND BASE IN MM): rim, $6.5 \mathrm{~mm}$; body, $7.7 \mathrm{~mm}$

INTERIOR SURFACE TREATMENT:

smoothed on the rim and body

EXTERIOR SURFACE TREATMENT: smoothed on the rim and body

HEIGHT (IN CM): 19.0

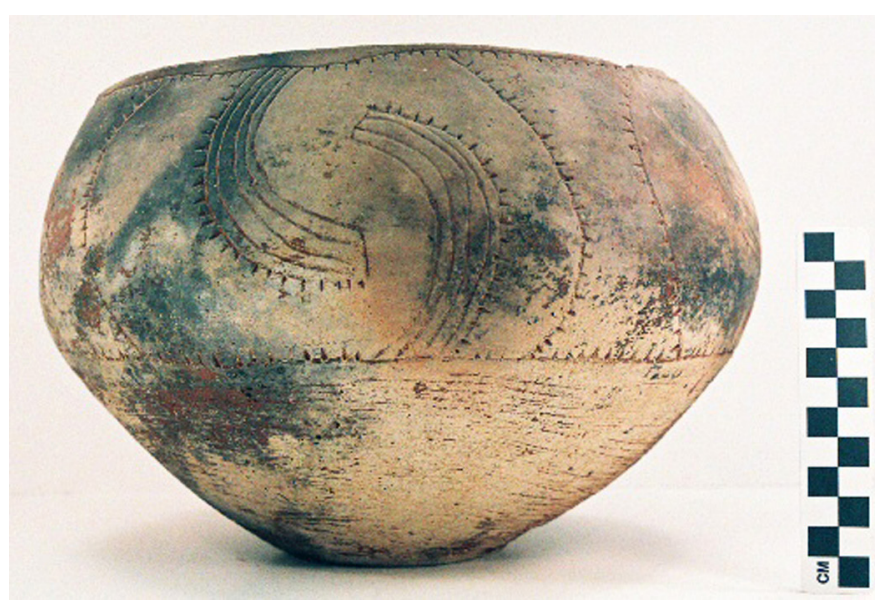

Figure 8. Patton Engraved, var. Patton carinated bowl from the R. L. Jowell Farm.

ORIFICE DIAMETER (IN CM): ca. 25.0

DIAMETER AT BOTTOM OF RIM OR NECK (IN CM): 27.0

BASE DIAMETER (IN CM) AND SHAPE OF BASE: 8.5

ESTIMATED VOLUME (IN LITERS): 4.4

DECORATION (INCLUDING MOTIF AND ELEMENTS WHEN APPARENT): The rim panel has single upper and lower horizontal engraved lines with tick marks, and the panel is divided into four parts by open brackets with inward-pointing tick marks on both sides of the brackets (Figure 8). Each of the four parts 
have upper and lower sets of five or six enclosed curvilinear hooked arm elements, and the outer line of the set has outward-pointing tick marks. The vessel body is covered with horizontal brushed marks.

PIGMENT USE AND LOCATION ON VESSEL: none

TYPE AND VARIETY [IF KNOWN]: Patton Engraved, var. Patton

SITE NAME OR SITE NUMBER: R. L. Jowell Farm

VESSEL NO.: 41AN13-2

NON-PLASTICS AND PASTE: grog

VESSEL FORM: Carinated bowl

RIM AND LIP FORM: Inverted rim and rounded lip

CORE COLOR: H (fired in a reducing environment and cooled in the open air)

INTERIOR SURFACE COLOR: reddish-brown

EXTERIOR SURFACE COLOR: very dark gray

WALL THICKNESS (RIM, BODY, AND BASE

IN MM): rim, $6.4 \mathrm{~mm}$; body, $5.1 \mathrm{~mm}$

INTERIOR SURFACE TREATMENT: smoothed on the rim

EXTERIOR SURFACE TREATMENT: burnished on the rim

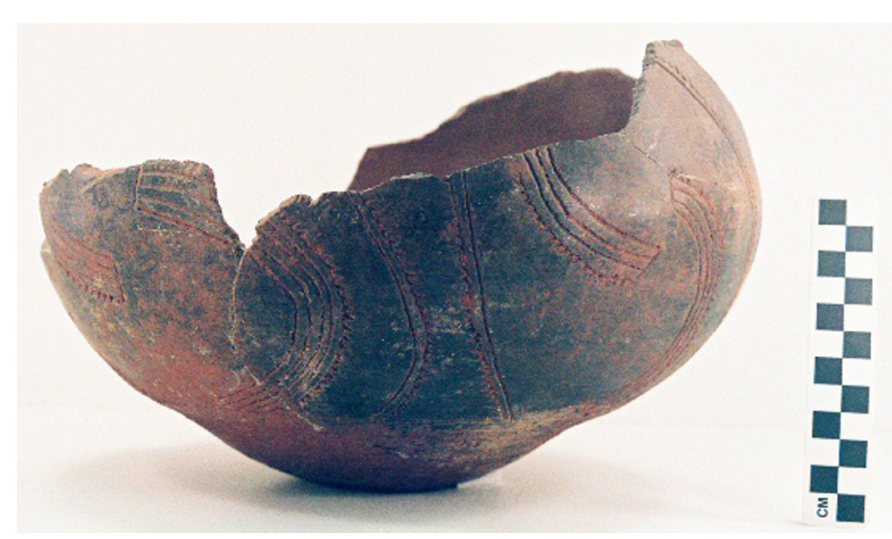

Figure 9. Patton Engraved, var. Patton carinated bowl from the R. L. Jowell Farm.

HEIGHT (IN CM): 17.7

ORIFICE DIAMETER (IN CM): 27.3

DIAMETER AT BOTTOM OF RIM OR NECK (IN CM): 28.0

BASE DIAMETER (IN CM) AND SHAPE OF BASE: 6.7; circular-flat

ESTIMATED VOLUME (IN LITERS): 4.3

DECORATION (INCLUDING MOTIF AND ELEMENTS WHEN APPARENT): The rim panel has single upper and lower horizontal engraved lines with upper linear tick marks and lower excised tick marks, and the panel is divided into four parts by sets of two curvilinear engraved lines with outward-pointing tick marks on the outer curvilinear line (Figure 9). Each of the four parts have upper and lower sets of five enclosed curvilinear hooked arm elements, and the outer line of the set has outward-pointing tick marks. The vessel body is covered with horizontal brushed marks. 
PIGMENT USE AND LOCATION ON VESSEL: red pigment in engraved lines

TYPE AND VARIETY [IF KNOWN]: Patton Engraved, var. Patton

SITE NAME OR SITE NUMBER: R. L. Jowell Farm

VESSEL NO.: 41AN13-3

NON-PLASTICS AND PASTE: grog and hematite

VESSEL FORM: cut-down Carinated Bowl. This cut-down vessel may have been used by Caddo potters as a ready-made mold for ceramic vessel manufacture. Such Caddo vessel sections have been recently labeled as kahwis, or earthen bowl (Chase Earles, July 7, 2014 personal communication).

RIM AND LIP FORM: N/A

CORE COLOR: A (fired and cooled in an oxidizing environment)

INTERIOR SURFACE COLOR: very pale brown

EXTERIOR SURFACE COLOR: very pale brown; fire clouds on the base

WALL THICKNESS (RIM, BODY, AND BASE IN MM): rim, $8.0 \mathrm{~mm}$

INTERIOR SURFACE TREATMENT: none

EXTERIOR SURFACE TREATMENT: none

HEIGHT (IN CM): 10.2

ORIFICE DIAMETER (IN CM): 28.0

DIAMETER AT BOTTOM OF RIM OR NECK

(IN CM): 27.9

BASE DIAMETER (IN CM) AND SHAPE OF

BASE: 7.4; circular-flat

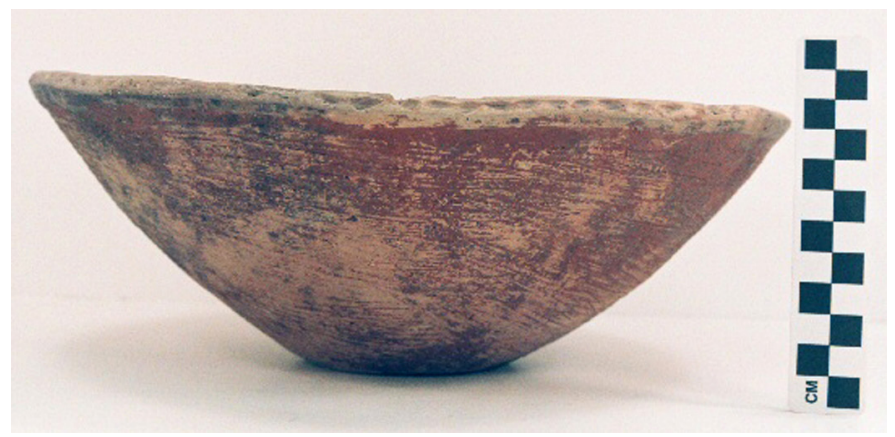

Figure 10. Cut-down carinated bowl with a brushed body from the R. L. Jowell site.

\section{ESTIMATED VOLUME (IN LITERS): 1.7}

DECORATION (INCLUDING MOTIF AND ELEMENTS WHEN APPARENT): The lip of the cut-down rim has large rectangular excised areas, and there are horizontal and overlapping brushing marks on the vessel body (Figure 10).

PIGMENT USE AND LOCATION ON VESSEL: none

TYPE AND VARIETY [IF KNOWN]: Unidentified fine ware 
SITE NAME OR SITE NUMBER: R. L. Jowell Farm

VESSEL NO.: 41AN13-4

NON-PLASTICS AND PASTE: grog

VESSEL FORM: Carinated Bowl

RIM AND LIP FORM: Inverted rim and rounded lip

CORE COLOR: A (fired and cooled in an oxidizing environment)

INTERIOR SURFACE COLOR: pink; fire clouds on the body and base

EXTERIOR SURFACE COLOR: pink; black film or resin on the rim

WALL THICKNESS (RIM, BODY, AND BASE

IN MM): rim, $6.9 \mathrm{~mm}$; body, $9.1 \mathrm{~mm}$

INTERIOR SURFACE TREATMENT: smoothed on the rim and body

EXTERIOR SURFACE TREATMENT: smoothed on the rim and body

HEIGHT (IN CM): 20.6

ORIFICE DIAMETER (IN CM): 25.9

DIAMETER AT BOTTOM OF RIM OR NECK (IN CM): 26.2

BASE DIAMETER (IN CM) AND SHAPE OF BASE: 7.0; circular-flat

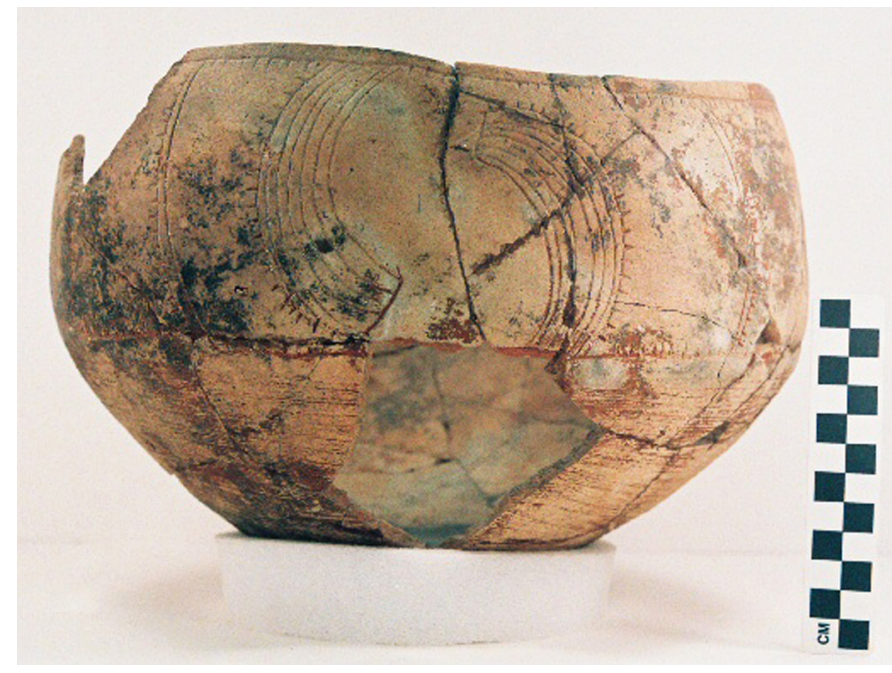

Figure 11. Patton Engraved, var. Patton carinated bowl from the R. L. Jowell site.

\section{ESTIMATED VOLUME (IN LITERS): 4.8}

DECORATION (INCLUDING MOTIF AND ELEMENTS WHEN APPARENT): The rim panel has single upper and lower horizontal engraved lines with linear tick marks, and the panel is divided into four parts by sets of two curvilinear engraved lines with outward-pointing linear tick marks on the outer curvilinear line (Figure 11). Each of the four parts have upper and lower sets of six enclosed curvilinear hooked arm elements, and the outer line of the set has outward-pointing linear tick marks. The vessel body is covered with horizontal and overlapping brushed marks.

PIGMENT USE AND LOCATION ON VESSEL: white pigment in engraved lines

TYPE AND VARIETY [IF KNOWN]: Patton Engraved, var. Patton 
SITE NAME OR SITE NUMBER: R. L. Jowell Farm

VESSEL NO.: 41AN13-5

NON-PLASTICS AND PASTE: grog

VESSEL FORM: Globular Bowl

RIM AND LIP FORM: direct rim and the lip is missing

CORE COLOR: A (fired and cooled in an oxidizing environment)

INTERIOR SURFACE COLOR: pale brown

EXTERIOR SURFACE COLOR: pinkish-gray

WALL THICKNESS (RIM, BODY, AND BASE IN MM): rim, 4.9 mm; body, $7.1 \mathrm{~mm}$

INTERIOR SURFACE TREATMENT: smoothed on the rim and body

EXTERIOR SURFACE TREATMENT: smoothed on the rim and body

HEIGHT (IN CM): N/A

ORIFICE DIAMETER (IN CM): N/A

DIAMETER AT BOTTOM OF RIM OR NECK (IN CM): 11.1

BASE DIAMETER (IN CM) AND SHAPE OF BASE: 6.0; circular-flat

ESTIMATED VOLUME (IN LITERS): N/A

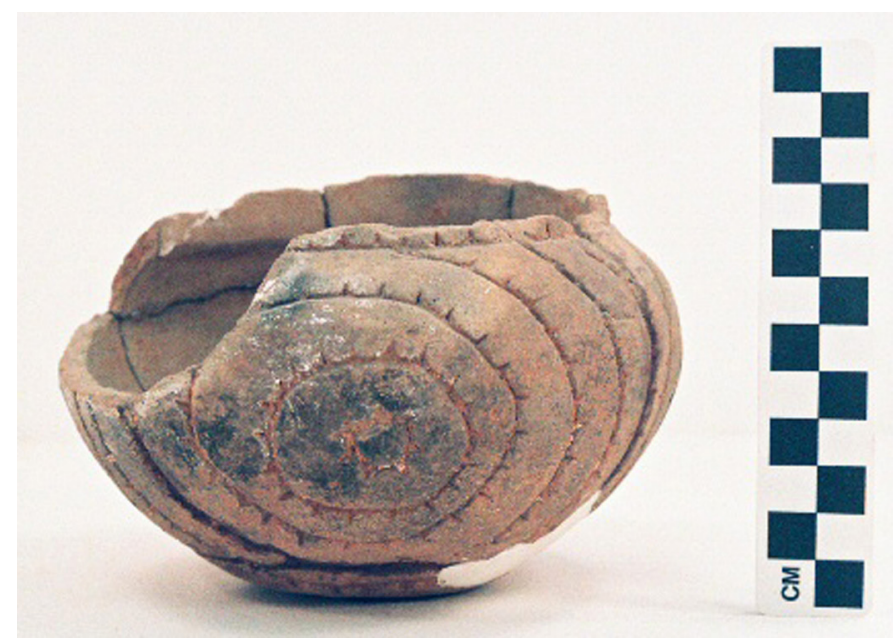

Figure 12. Patton Engraved, var. Freeman carinated bowl from the R. L. Jowell site.

DECORATION (INCLUDING MOTIF AND ELEMENTS WHEN APPARENT): The lower half of the rim is marked by a single horizontal engraved line with upward-pointing tick marks. The rim is divided into panels by sets of vertical engraved lines. The vessel body has three sets of concentric circle motifs, and each concentric circle has outward-pointing tick marks (Figure 12).

PIGMENT USE AND LOCATION ON VESSEL: white pigment in engraved lines

TYPE AND VARIETY [IF KNOWN]: Patton Engraved, var. Freeman 
SITE NAME OR SITE NUMBER: R. L. Jowell Farm

VESSEL NO.: 41AN13-6

NON-PLASTICS AND PASTE: grog and hematite; fine sandy paste

VESSEL FORM: Carinated bowl

RIM AND LIP FORM: Inverted rim and a rounded lip

CORE COLOR: A (fired and cooled in an oxidizing environment)

INTERIOR SURFACE COLOR: pale brown

EXTERIOR SURFACE COLOR: light yellowish-brown

WALL THICKNESS (RIM, BODY, AND BASE

IN MM): rim, $4.8 \mathrm{~mm}$; body, $5.3 \mathrm{~mm}$

INTERIOR SURFACE TREATMENT: smoothed on the rim and body

EXTERIOR SURFACE TREATMENT: smoothed on the rim and body

HEIGHT (IN CM): 17.5

ORIFICE DIAMETER (IN CM): 23.4

DIAMETER AT BOTTOM OF RIM OR NECK (IN CM): 24.5

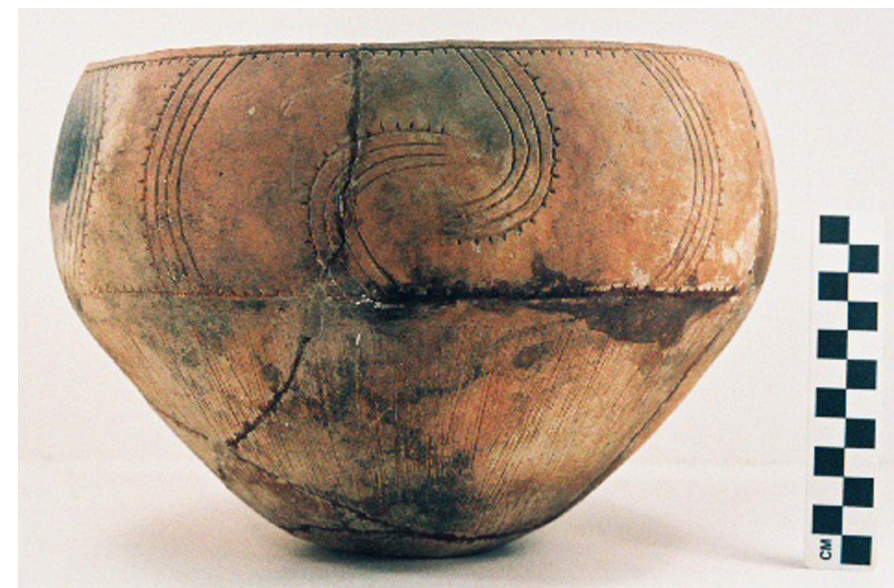

Figure 13. Patton Engraved, var. Patton carinated bowl from the R. L. Jowell farm site.

BASE DIAMETER (IN CM) AND SHAPE OF BASE: 6.2; circular and flat

\section{ESTIMATED VOLUME (IN LITERS): 3.7}

DECORATION (INCLUDING MOTIF AND ELEMENTS WHEN APPARENT): The rim panel has single upper and lower horizontal engraved lines with tick marks, and the panel is divided into four parts by open brackets with inward-pointing tick marks on both sides of the brackets (Figure 13). Each of the four parts have upper and lower sets of four closely-spaced curvilinear hooked arm elements, and the outer line of the set has outward-pointing tick marks. The vessel body is covered with vertical horizontal brushed marks.

PIGMENT USE AND LOCATION ON VESSEL: white pigment in engraved lines

TYPE AND VARIETY [IF KNOWN]: Patton Engraved, var. Patton 
SITE NAME OR SITE NUMBER: R. L. Jowell Farm

VESSEL NO.: 41AN13-8

NON-PLASTICS AND PASTE: grog and hematite

VESSEL FORM: Globular bowl

RIM AND LIP FORM: N/A

CORE COLOR: A (fired and cooled in an oxidizing environment)

INTERIOR SURFACE COLOR: pink; fire clouds on the base

EXTERIOR SURFACE COLOR: light brown; fire clouds on the body and base

WALL THICKNESS (RIM, BODY, AND BASE IN MM): rim, 4.8 mm

INTERIOR SURFACE TREATMENT: smoothed on the body

EXTERIOR SURFACE TREATMENT:

smoothed on the body

HEIGHT (IN CM): 12.5+ [from the base to the bottom of the rim]

ORIFICE DIAMETER (IN CM): 17.6

DIAMETER AT BOTTOM OF RIM OR NECK

(IN CM): $20.8 \mathrm{~cm}$ at the widest point on the body

BASE DIAMETER (IN CM) AND SHAPE OF

BASE: 5.5

ESTIMATED VOLUME (IN LITERS): N/A

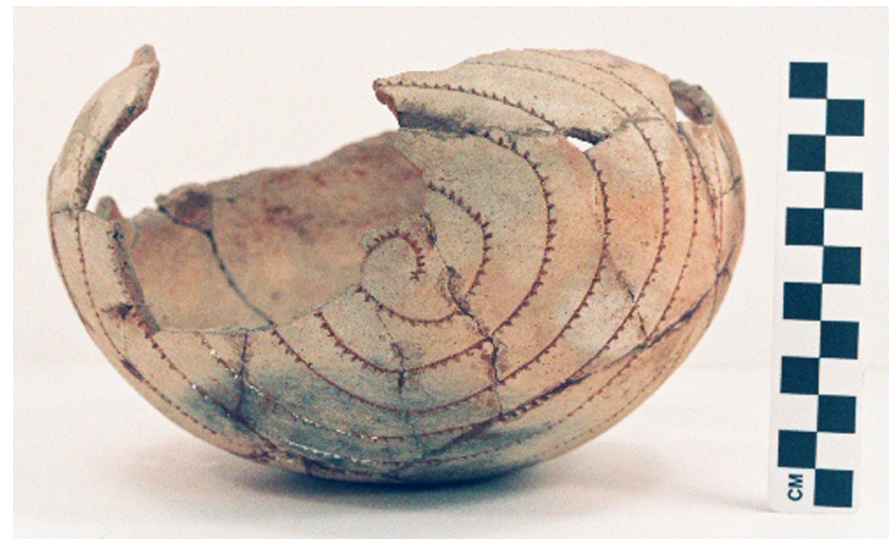

Figure 14. cf. Patton Engraved, var. Freeman globular bowl from the R. L. Jowell site.

DECORATION (INCLUDING MOTIF AND ELEMENTS WHEN APPARENT): The small remnant of the rim includes a horizontal engraved line at the carination; the line has upward-pointing excised tick marks. The vessel body has engraved spirals with outward-facing excised tick marks on each spiraling line (Figure 14).

PIGMENT USE AND LOCATION ON VESSEL: white pigment in engraved lines

TYPE AND VARIETY [IF KNOWN]: cf. Patton Engraved, var. Freeman 
SITE NAME OR SITE NUMBER: R. L. Jowell

VESSEL NO.: 41AN13-9

NON-PLASTICS AND PASTE: grog and hematite

VESSEL FORM: Globular bowl

RIM AND LIP FORM: Direct rim and rounded lip

CORE COLOR: A (fired and cooled in an oxidizing environment)

INTERIOR SURFACE COLOR: very pale brown; fire clouds on the base

EXTERIOR SURFACE COLOR: pink; fire clouds on the body and base

WALL THICKNESS (RIM, BODY, AND BASE

IN MM): rim, $4.8 \mathrm{~mm}$

INTERIOR SURFACE TREATMENT: smoothed on the rim

EXTERIOR SURFACE TREATMENT: smoothed on the rim and body

HEIGHT (IN CM): 7.2

ORIFICE DIAMETER (IN CM): 10.2

DIAMETER AT BOTTOM OF RIM OR NECK (IN CM): 9.7

BASE DIAMETER (IN CM) AND SHAPE OF BASE: 5.0

ESTIMATED VOLUME (IN LITERS): 0.3

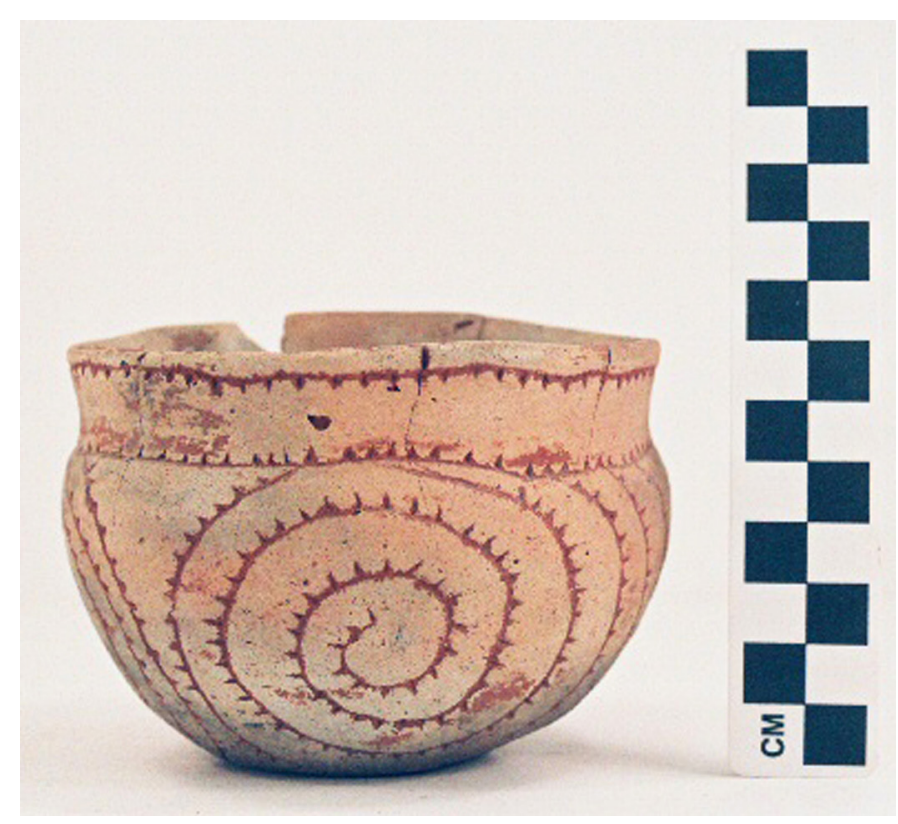

Figure 15. cf. Patton Engraved, var. Freeman globular bowl from the R. L. Jowell site.

DECORATION (INCLUDING MOTIF AND ELEMENTS WHEN APPARENT): The rim has upper and lower horizontal engraved lines with triangular tick marks. The vessel body has two spirals and hooked arm motifs with outward-pointing tick marks on the engraved lines as well as a single concentric circle motif with outward-pointing tick marks along each concentric circle (Figure 15).

PIGMENT USE AND LOCATION ON VESSEL: red pigment in engraved lines TYPE AND VARIETY [IF KNOWN]: cf. Patton Engraved, var. Freeman 
SITE NAME OR SITE NUMBER: R. L. Jowell Farm

VESSEL NO.: 41AN13-10

NON-PLASTICS AND PASTE: grog

VESSEL FORM: Carinated bowl

RIM AND LIP FORM: Direct rim and a rounded lip

CORE COLOR: F (fired in a reducing environment and cooled in the open air)

INTERIOR SURFACE COLOR: yellowish-brown; fire clouds

EXTERIOR SURFACE COLOR: strong brown; fire clouds on the base

WALL THICKNESS (RIM, BODY, AND BASE IN MM): rim, $5.5 \mathrm{~mm}$

INTERIOR SURFACE TREATMENT: smoothed

on the rim and body

EXTERIOR SURFACE TREATMENT:

smoothed on the rim and body

HEIGHT (IN CM): 5.0

ORIFICE DIAMETER (IN CM): 15.0

DIAMETER AT BOTTOM OF RIM OR NECK

(IN CM): 14.0

BASE DIAMETER (IN CM) AND SHAPE OF

BASE: 9.0; circular and flat

ESTIMATED VOLUME (IN LITERS): 0.45

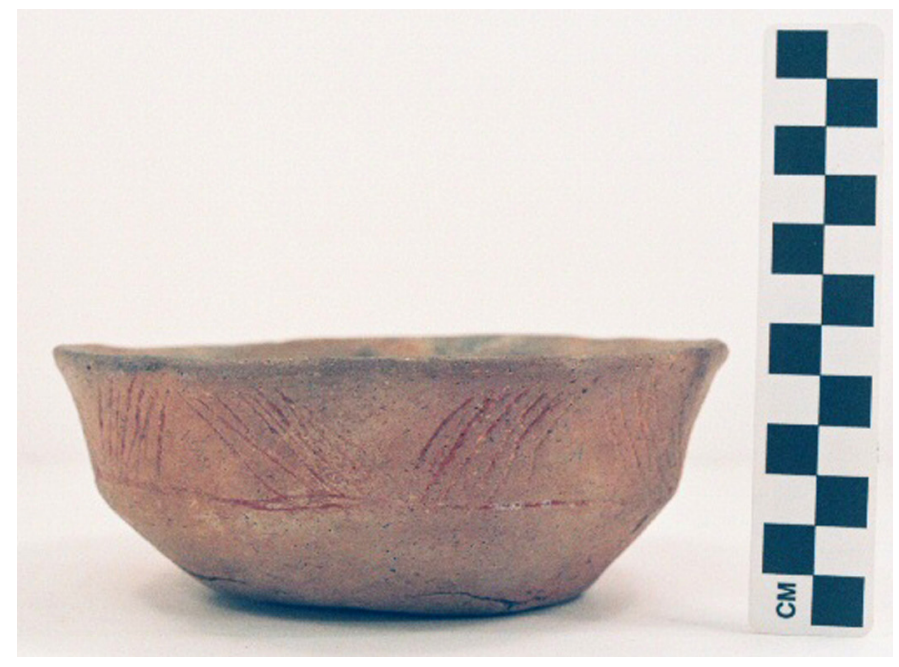

Figure 16. Unidentified engraved carinated bowl from the R. L. Jowell site.

DECORATION (INCLUDING MOTIF AND ELEMENTS WHEN APPARENT): The rim panel has a series of diagonal opposed engraved lines forming seven upper open triangles and six lower open triangles (Figure 16). A single horizontal engraved line is present belong the triangle elements at the vessel carination.

PIGMENT USE AND LOCATION ON VESSEL: red pigment in engraved lines

TYPE AND VARIETY [IF KNOWN]: Unidentified fine ware, resembling Sanders Engraved, a Middle Caddo period ceramic type. 
SITE NAME OR SITE NUMBER: R. L. Jowell Farm

VESSEL NO.: 41AN13-11

NON-PLASTICS AND PASTE: grog-hematite; fine sandy paste

VESSEL FORM: cut-down Carinated Bowl. This may also be a kahwis, or a ceramic vessel used as a mold for vessel manufacture.

RIM AND LIP FORM: N/A

CORE COLOR: F (fired in a reducing environment and cooled in the open air)

INTERIOR SURFACE COLOR: light brown; fire clouding

EXTERIOR SURFACE COLOR: very pale brown; fire clouding

WALL THICKNESS (RIM, BODY, AND BASE

IN MM): $\operatorname{rim}, 4.7 \mathrm{~mm}$

INTERIOR SURFACE TREATMENT: smoothed on the body

EXTERIOR SURFACE TREATMENT: smoothed on the body

HEIGHT (IN CM): 6.3+

ORIFICE DIAMETER (IN CM): 13.5

DIAMETER AT BOTTOM OF RIM OR NECK (IN CM): 14.0

BASE DIAMETER (IN CM) AND SHAPE OF BASE: 5.0; circular-flat
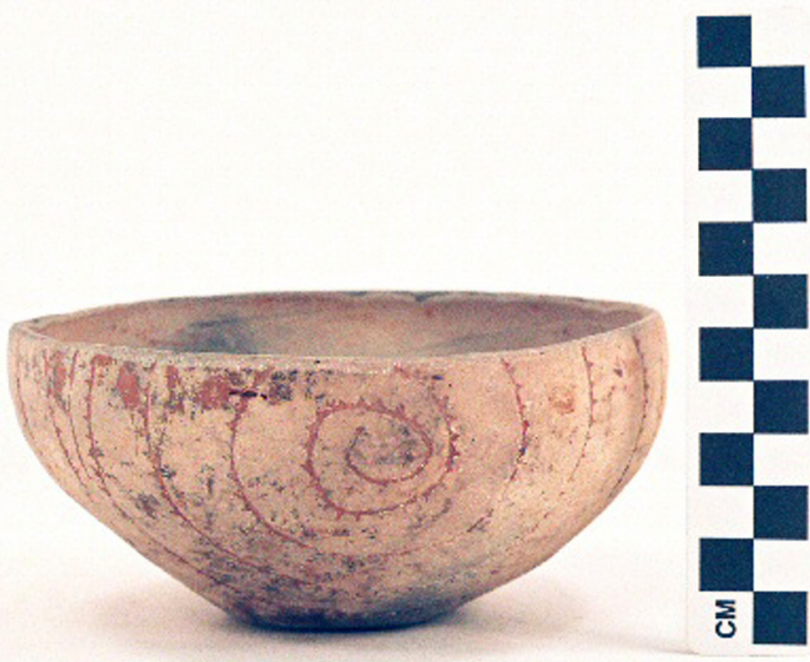

Figure 17. Cut-down Patton Engraved, var. Freeman carinated bowl from the R. L. Jowell site.

ESTIMATED VOLUME (IN LITERS): 0.5

DECORATION (INCLUDING MOTIF AND ELEMENTS WHEN APPARENT): The vessel has three sets of engraved spirals that end in a hooked arm element (Figure 17). Each line of the spirals has outwardpointing tick marks.

PIGMENT USE AND LOCATION ON VESSEL: white pigment in engraved lines TYPE AND VARIETY [IF KNOWN]: Patton Engraved, var. Freeman 
SITE NAME OR SITE NUMBER: R. L. Jowell Farm

VESSEL NO.: 41AN13-12

NON-PLASTICS AND PASTE: grog, bone, and hematite; fine sandy paste

VESSEL FORM: Carinated bowl

RIM AND LIP FORM: Direct rim and rounded lip

CORE COLOR: F (fired in a reducing environment and cooled in the open air)

INTERIOR SURFACE COLOR: brown

EXTERIOR SURFACE COLOR: brown

WALL THICKNESS (RIM, BODY, AND BASE

IN MM): rim, $6.6 \mathrm{~mm}$

INTERIOR SURFACE TREATMENT: smoothed on the rim and body

EXTERIOR SURFACE TREATMENT: smoothed on the rim and body

HEIGHT (IN CM): 5.5

ORIFICE DIAMETER (IN CM): 9.0

DIAMETER AT BOTTOM OF RIM OR NECK (IN CM): 9.3

BASE DIAMETER (IN CM) AND SHAPE OF

BASE: 5.5; circular and flat

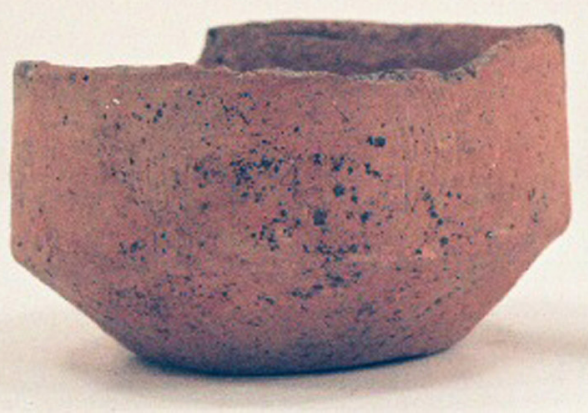

Figure 18. Poynor Engraved, var. Cook carinated bowl from the R. L. Jowell Farm site.

ESTIMATED VOLUME (IN LITERS): 0.3

DECORATION (INCLUDING MOTIF AND ELEMENTS WHEN APPARENT): The rim panel is defined by a single horizontal engraved line immediately above the vessel carination. On the panel are five negative ovals defined by a series of eight vertical to arcing engraved lines (Figure 18).

PIGMENT USE AND LOCATION ON VESSEL: none

TYPE AND VARIETY [IF KNOWN]: Poynor Engraved, var. Cook 
SITE NAME OR SITE NUMBER: R. L. Jowell Farm

VESSEL NO.: 41AN13-13

NON-PLASTICS AND PASTE: grog and hematite

VESSEL FORM: Small Bowl

RIM AND LIP FORM: Direct rim and a rounded lip

CORE COLOR: A (fired and cooled in an oxidizing environment)

INTERIOR SURFACE COLOR: light brown

EXTERIOR SURFACE COLOR: reddish-yellow;

fire clouds on the body and base

WALL THICKNESS (RIM, BODY, AND BASE

IN MM): rim, $5.9 \mathrm{~mm}$

INTERIOR SURFACE TREATMENT: none

EXTERIOR SURFACE TREATMENT: none

HEIGHT (IN CM): 4.1

ORIFICE DIAMETER (IN CM): 7.3

DIAMETER AT BOTTOM OF RIM OR NECK (IN CM): N/A

BASE DIAMETER (IN CM) AND SHAPE OF BASE: 5.2; circular and flat

\section{ESTIMATED VOLUME (IN LITERS): 0.12}
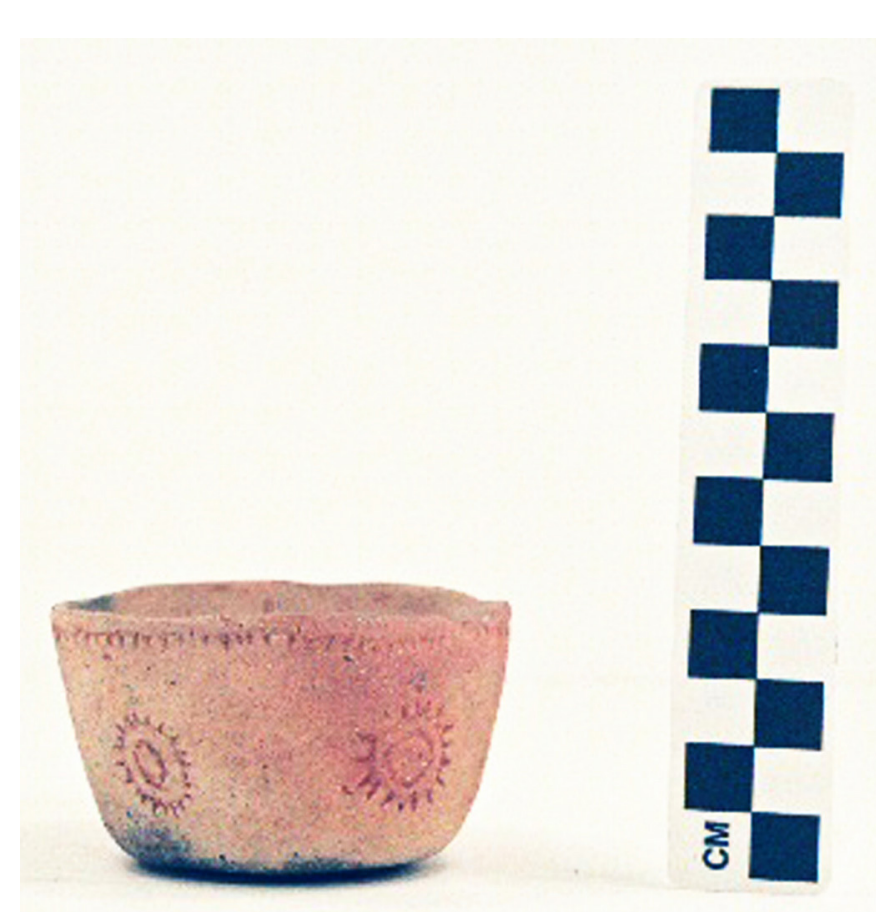

Figure 19. Patton Engraved, var. unspecified bowl from the R. L. Jowell site.

DECORATION (INCLUDING MOTIF AND ELEMENTS WHEN APPARENT): There is a single horizontal engraved line below the vessel lip; it has downward-pointing excised tick marks. On the vessel body is a circular engraved element (with two circular lines) with outward-pointing tick marks on the outer circle (Figure 19). This element is repeated five times around the vessel.

PIGMENT USE AND LOCATION ON VESSEL: red pigment in engraved lines

TYPE AND VARIETY [IF KNOWN]: Patton Engraved, var. unspecified 
SITE NAME OR SITE NUMBER: R. L. Jowell Farm

VESSEL NO.: 41AN13-14

NON-PLASTICS AND PASTE: grog

VESSEL FORM: Bowl with two opposed lug handles

RIM AND LIP FORM: Direct rim and rounded lip

CORE COLOR: A (fired and cooled in an oxidizing environment)

INTERIOR SURFACE COLOR: pale brown

EXTERIOR SURFACE COLOR: light brown;

fire clouds on the base

WALL THICKNESS (RIM, BODY, AND BASE

IN MM): rim, $5.4 \mathrm{~mm}$

INTERIOR SURFACE TREATMENT: smoothed on the rim and body

EXTERIOR SURFACE TREATMENT: none

HEIGHT (IN CM): 4.0

ORIFICE DIAMETER (IN CM): 8.5

DIAMETER AT BOTTOM OF RIM OR NECK (IN CM): N/A

BASE DIAMETER (IN CM) AND SHAPE OF

BASE: 2.0; circular and flat

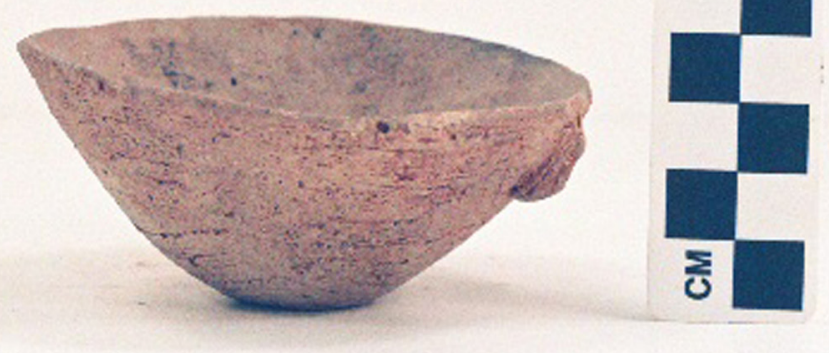

Figure 20. Brushed bowl from the R. L. Jowell site.

ESTIMATED VOLUME (IN LITERS): 0.14

DECORATION (INCLUDING MOTIF AND ELEMENTS WHEN APPARENT): The bowl has horizontal and opposed brushing marks over the entire vessel rim and body (Figure 20).

PIGMENT USE AND LOCATION ON VESSEL: none

TYPE AND VARIETY [IF KNOWN]: Unidentified utility ware 
SITE NAME OR SITE NUMBER: R. L. Jowell Farm

VESSEL NO.: 41AN13-15

NON-PLASTICS AND PASTE: grog and hematite

VESSEL FORM: Jar

RIM AND LIP FORM: N/A

CORE COLOR: $\mathrm{G}$ (fired in a reducing environment and cooled in the open air)

INTERIOR SURFACE COLOR: light gray; fire clouding

EXTERIOR SURFACE COLOR: light brownishgray; fire clouding

WALL THICKNESS (RIM, BODY, AND BASE IN MM): body, $6.2 \mathrm{~mm}$

INTERIOR SURFACE TREATMENT: smoothed on the body

EXTERIOR SURFACE TREATMENT: none

HEIGHT (IN CM): 8.0 (height of body section)

ORIFICE DIAMETER (IN CM): 10.5

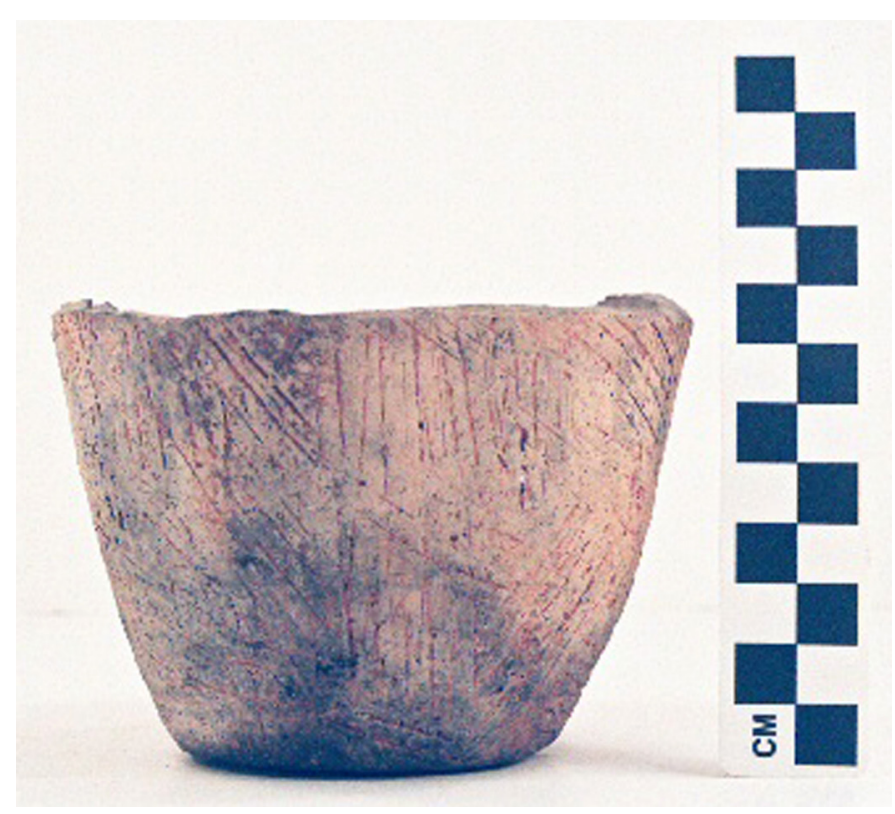

Figure 21. Probable Bullard Brushed jar body section from the R. L. Jowell site.

DIAMETER AT BOTTOM OF RIM OR NECK (IN CM): N/A

BASE DIAMETER (IN CM) AND SHAPE OF BASE: 6.5; circular and flat

ESTIMATED VOLUME (IN LITERS): N/A

DECORATION (INCLUDING MOTIF AND ELEMENTS WHEN APPARENT): Vertical, opposed, and overlapping brushed marks cover the entire vessel body (Figure 21).

PIGMENT USE AND LOCATION ON VESSEL: none

TYPE AND VARIETY [IF KNOWN]: probably Bullard Brushed 
SITE NAME OR SITE NUMBER: R. L. Jowell Farm

VESSEL NO.: 41AN13-16

NON-PLASTICS AND PASTE: grog

VESSEL FORM: Jar with two opposed lug handles below the vessel lip

RIM AND LIP FORM: Direct rim, and a rounded and exterior folded lip

CORE COLOR: B (fired and cooled in a reducing environment)

INTERIOR SURFACE COLOR: dark grayishbrown

EXTERIOR SURFACE COLOR: very dark grayish-brown

WALL THICKNESS (RIM, BODY, AND BASE IN MM): rim, $5.7 \mathrm{~mm}$

INTERIOR SURFACE TREATMENT: smoothed on the rim and body

EXTERIOR SURFACE TREATMENT: none

HEIGHT (IN CM): 8.0

ORIFICE DIAMETER (IN CM): 7.2

DIAMETER AT BOTTOM OF RIM OR NECK (IN CM): 7.2

BASE DIAMETER (IN CM) AND SHAPE OF BASE: 6.2 ; circular and flat

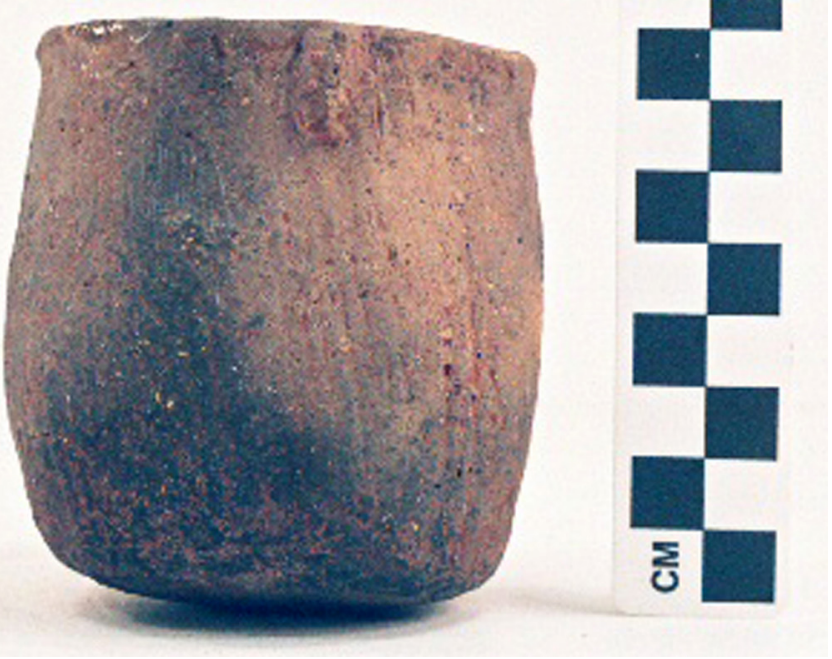

Figure 22. Bullard Brushed jar from the R. L. Jowell Farm site.

ESTIMATED VOLUME (IN LITERS): 0.35

DECORATION (INCLUDING MOTIF AND ELEMENTS WHEN APPARENT): The rim and body of the vessel primarily has vertical brushing marks (Figure 22), but there is one area on the body where the brushing is overlapping.

PIGMENT USE AND LOCATION ON VESSEL: none

TYPE AND VARIETY [IF KNOWN]: Bullard Brushed 


\section{Mrs. Emma Owens Site (41AN21) Vessel}

The Mrs. Emma Owens site is on an unnamed tributary of Caddo Creek. UT archeologists excavated here in 1931, exposing one burial, midden deposits, and a pit feature (Cole 1975:120). The one vessel from the site had been placed by the left shoulder of a Caddo adult man, along with a clay pipe and a metal knife blade (Cole 1975:125).

\section{SITE NAME OR SITE NUMBER:}

VESSEL NO.: G-1/41AN21-9

NON-PLASTICS AND PASTE: grog-hematite and a fine sandy paste

VESSEL FORM: Bowl

RIM AND LIP FORM: Everted rim and a rounded lip

CORE COLOR: A (fired and cooled in an oxidizing environment)

INTERIOR SURFACE COLOR: light yellowishbrown; fire clouds on the base

EXTERIOR SURFACE COLOR: light yellowishbrown

WALL THICKNESS (RIM, BODY, AND BASE IN MM): rim, $3.8 \mathrm{~mm}$

INTERIOR SURFACE TREATMENT: smoothed on the rim and body

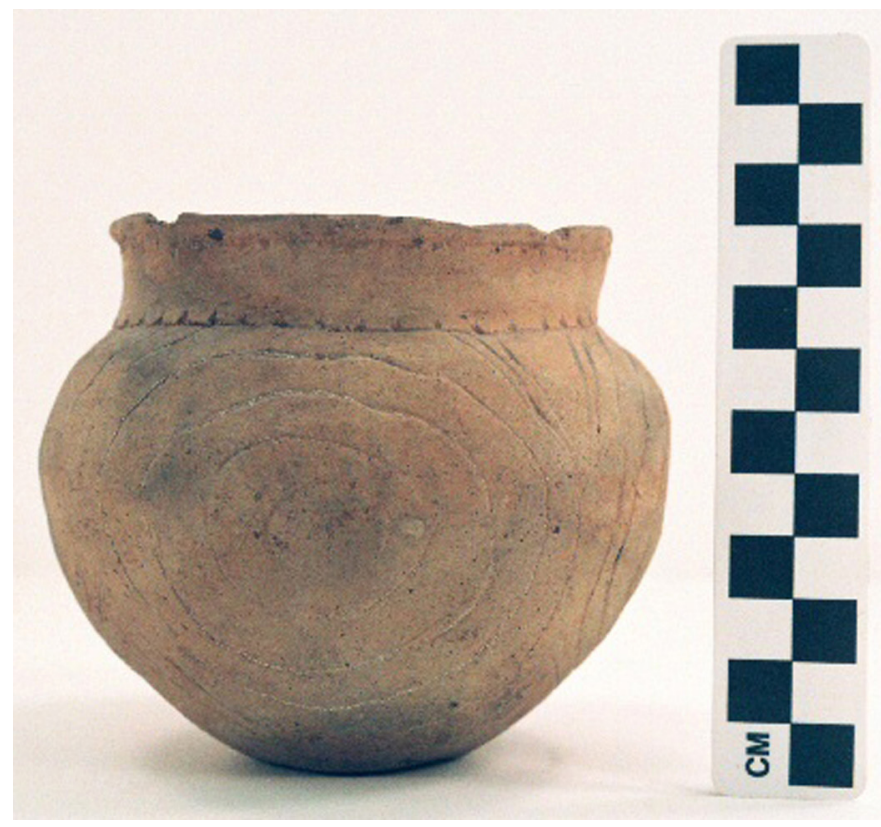

Figure 23. cf. Poynor Engraved, var. Freeman bowl from the Mrs. Emma Owens site.

EXTERIOR SURFACE TREATMENT: smoothed on the rim

HEIGHT (IN CM): 7.5

ORIFICE DIAMETER (IN CM): 9.0

DIAMETER AT BOTTOM OF RIM OR NECK (IN CM): 8.7

BASE DIAMETER (IN CM) AND SHAPE OF BASE: 4.5

ESTIMATED VOLUME (IN LITERS): 0.3

DECORATION (INCLUDING MOTIF AND ELEMENTS WHEN APPARENT): The rim has two horizontal engraved lines that encircle the vessel, and these lines have upwards- and downwards-pointing excised tick marks. The vessel body has an engraved concentric circle motif repeated four times around the vessel (Figure 23).

PIGMENT USE AND LOCATION ON VESSEL: none

TYPE AND VARIETY [IF KNOWN]: cf. Poynor Engraved, var. Freeman 


\section{Richard Patton Site (41AN26) Vessels}

The Richard Patton site has ancestral Caddo habitation deposits as well as a small cemetery. The landowner, Mr. Patton, located and excavated 12 burials there, in two north-south rows (Perttula et al. 2011:Figure 11-6), and recovered 29 ceramic vessels (Cole 1975:129). These vessels were purchased in 1933 by The University of Texas (UT) (Marceaux 2011:418). Two blue glass beads were found in one burial re-investigated by UT in 1933 (Cole 1975:Table 8).

SITE NAME OR SITE NUMBER: Richard Patton

VESSEL NO.: 41AN26-1

NON-PLASTICS AND PASTE: fine grog; sandy paste

VESSEL FORM: Carinated Bowl

RIM AND LIP FORM: Inverted rim and flat lip

CORE COLOR: A (fired and cooled in an oxidizing environment)

INTERIOR SURFACE COLOR: light gray EXTERIOR SURFACE COLOR: light gray

WALL THICKNESS (RIM, BODY, AND BASE IN MM): rim, $6.4 \mathrm{~mm}$

INTERIOR SURFACE TREATMENT: smoothed on the rim

EXTERIOR SURFACE TREATMENT: poorly smoothed on the rim

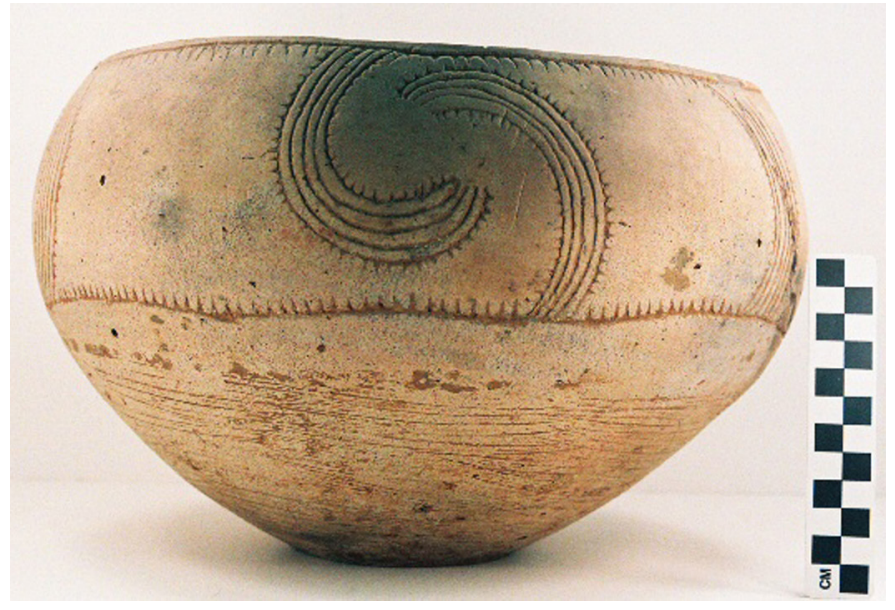

Figure 24. Patton Engraved, var. Patton carinated bowl from the Richard Patton site.

HEIGHT (IN CM): 19.5

ORIFICE DIAMETER (IN CM): 27.2

DIAMETER AT BOTTOM OF RIM OR NECK (IN CM): 29.0

BASE DIAMETER (IN CM) AND SHAPE OF BASE: 9.3; circular and flat ESTIMATED VOLUME (IN LITERS): 4.8

DECORATION (INCLUDING MOTIF AND ELEMENTS WHEN APPARENT): The rim panel is defined by single upper and lower horizontal engraved lines with either downward- or upwards-pointing linear tick 
marks. The panel itself has three sets of upper and lower hooked arm elements that are each comprised of five closely-spaced arcing lines; the inner and outer lines of each set of engraved lines have outwardpointing excised tick marks (Figure 24). The hooked arm elements are divided by near vertical arcing sets of six engraved lines; the inner and outer lines have outward-pointing excised tick marks. The lower part of the vessel body has horizontal brushing marks.

PIGMENT USE AND LOCATION ON VESSEL: none

TYPE AND VARIETY [IF KNOWN]: Patton Engraved, var. Patton

SITE NAME OR SITE NUMBER: Richard Patton

VESSEL NO.: 41AN26-3

NON-PLASTICS AND PASTE: grog and hematite; fine sandy paste

VESSEL FORM: Carinated Bowl

RIM AND LIP FORM: Inverted rim and rounded lip

CORE COLOR: A (fired and cooled in an oxidizing environment)

INTERIOR SURFACE COLOR: very pale brown

EXTERIOR SURFACE COLOR: very pale brown

WALL THICKNESS (RIM, BODY, AND BASE IN MM): rim, $6.5 \mathrm{~mm}$

INTERIOR SURFACE TREATMENT: smoothed on the rim and base

EXTERIOR SURFACE TREATMENT: smoothed on the rim

HEIGHT (IN CM): 15.4

ORIFICE DIAMETER (IN CM): 19.6

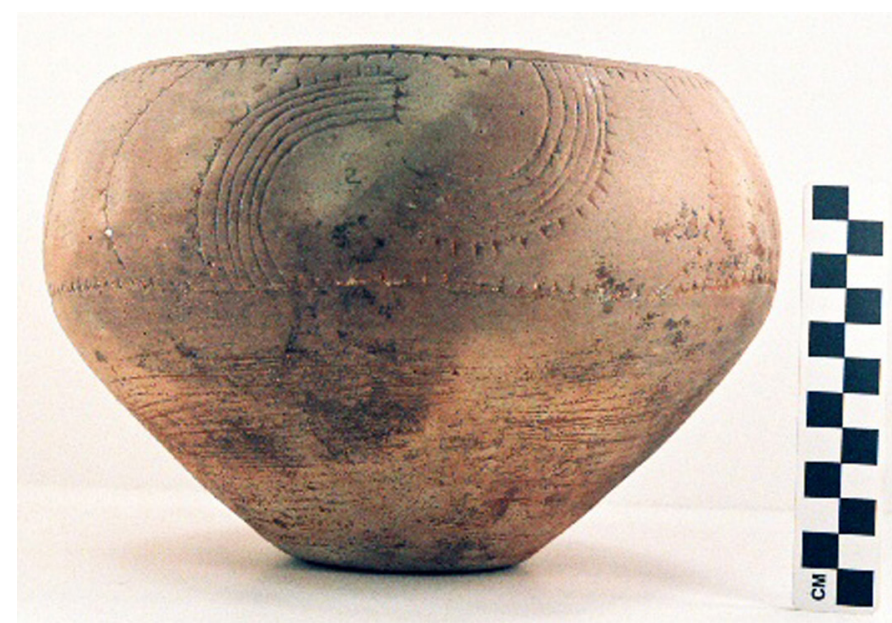

Figure 25. Patton Engraved, var. Patton carinated bowl from the Richard Patton site.

DIAMETER AT BOTTOM OF RIM OR NECK (IN CM): 22.4

BASE DIAMETER (IN CM) AND SHAPE OF BASE: 8.4; circular and flat ESTIMATED VOLUME (IN LITERS): 2.7

DECORATION (INCLUDING MOTIF AND ELEMENTS WHEN APPARENT): The rim panel is defined by single upper and lower horizontal engraved lines with upwards- or downwards-pointing linear tick marks. The rim panel itself has three sets of hooked arm elements comprised of six curvilinear arcing lines 
(Figure 25). The outer lines of each set of hooked arm elements have outward-pointing excised tick marks, and there are also excised tick marks at the vertical end of the hooked arms. The hooked arm elements are divided by open engraved bracket elements with inward-pointing excised tick marks on each side of the bracket (Figure 25). The vessel body has horizontal brushing marks.

PIGMENT USE AND LOCATION ON VESSEL: white pigment in the engraved lines

TYPE AND VARIETY [IF KNOWN]: Patton Engraved, var. Patton

SITE NAME OR SITE NUMBER: Richard Patton

VESSEL NO.: 41AN26-4

NON-PLASTICS AND PASTE: grog and hematite

VESSEL FORM: Carinated bowl

RIM AND LIP FORM: Inverted rim and a rounded lip

CORE COLOR: A (fired and cooled in an oxidizing environment)

INTERIOR SURFACE COLOR: very pale brown; fire clouds on the base

EXTERIOR SURFACE COLOR: very pale brown

WALL THICKNESS (RIM, BODY, AND BASE IN MM): rim, $5.7 \mathrm{~mm}$

INTERIOR SURFACE TREATMENT: smoothed on the rim

EXTERIOR SURFACE TREATMENT: smoothed on the rim; black film/smudging in patches across the vessel body

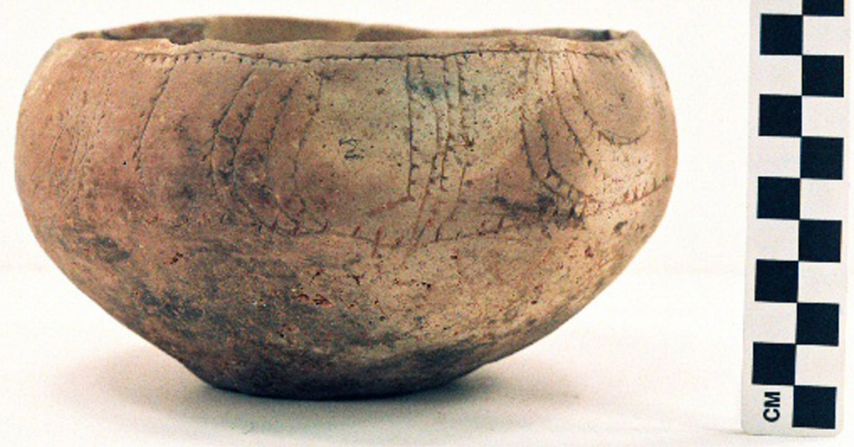

Figure 26. cf. Patton Engraved, var. Patton carinated bowl from the Richard Patton site.

HEIGHT (IN CM): 10.5

ORIFICE DIAMETER (IN CM): 16.0

DIAMETER AT BOTTOM OF RIM OR NECK (IN CM): $19.0 \mathrm{~cm}$

BASE DIAMETER (IN CM) AND SHAPE OF BASE: 8.0; circular and flat

ESTIMATED VOLUME (IN LITERS): 1.0

DECORATION (INCLUDING MOTIF AND ELEMENTS WHEN APPARENT): The rim panel is defined by single upper and lower horizontal engraved lines with either downwards- or upwards-pointing excised 
tick marks. The panel has six sets of closely-spaced curvilinear engraved lines that are each divided by five closely-spaced near-vertical engraved lines; four of these lines have outwards-pointing excised tick marks (Figure 26). The curvilinear engraved motif has five lines, each with outwards-pointing excised tick marks.

PIGMENT USE AND LOCATION ON VESSEL: none

TYPE AND VARIETY [IF KNOWN]: cf. Patton Engraved, var. Patton

SITE NAME OR SITE NUMBER: Richard Patton

VESSEL NO.: 41AN26-5

NON-PLASTICS AND PASTE: grog and hematite

VESSEL FORM: Carinated Bowl

RIM AND LIP FORM: Inverted rim and rounded lip

CORE COLOR: A (fired and cooled in an oxidizing environment)

INTERIOR SURFACE COLOR: yellowishbrown; fire clouds on the base

EXTERIOR SURFACE COLOR: brown; fire clouds on the rim

WALL THICKNESS (RIM, BODY, AND BASE

IN MM): rim, $6.2 \mathrm{~mm}$

INTERIOR SURFACE TREATMENT:

smoothed on the rim and body

EXTERIOR SURFACE TREATMENT: smoothed on the rim and body

HEIGHT (IN CM): 14.5

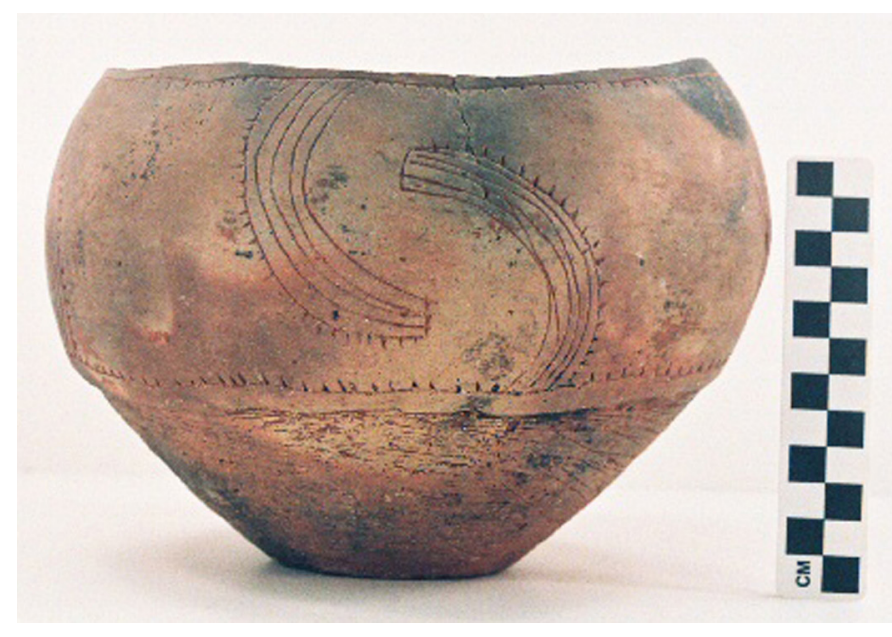

Figure 27. Patton Engraved, var. Patton carinated bowl from the Richard Patton site.

ORIFICE DIAMETER (IN CM): 18.0

DIAMETER AT BOTTOM OF RIM OR NECK (IN CM): $21.5 \mathrm{~cm}$ at the widest point on the body

BASE DIAMETER (IN CM) AND SHAPE OF BASE: 7.0; circular and flat

ESTIMATED VOLUME (IN LITERS): 2.3

DECORATION (INCLUDING MOTIF AND ELEMENTS WHEN APPARENT): The rim panel is defined by single upper and lower horizontal engraved lines with either downwards- or upwards-pointing excised tick marks. The panel has four sets of upper and lower enclosed hooked arm elements (Figure 27). The 
hooked arm elements each have five curvilinear lines, and the outer line has outwards-pointing excised tick marks. The vessel body has diagonal brushing marks.

PIGMENT USE AND LOCATION ON VESSEL: none

TYPE AND VARIETY [IF KNOWN]: Patton Engraved, var. Patton

SITE NAME OR SITE NUMBER: Richard Patton

VESSEL NO.: 41AN26-6

NON-PLASTICS AND PASTE: grog

VESSEL FORM: Carinated bowl

RIM AND LIP FORM: Inverted rim and rounded lip

CORE COLOR: A (fired and cooled in an

oxidizing environment)

INTERIOR SURFACE COLOR: light yellowishbrown

EXTERIOR SURFACE COLOR: light yellowishbrown; fire clouds on the body and base

WALL THICKNESS (RIM, BODY, AND BASE

IN MM): rim, $7.5 \mathrm{~mm}$

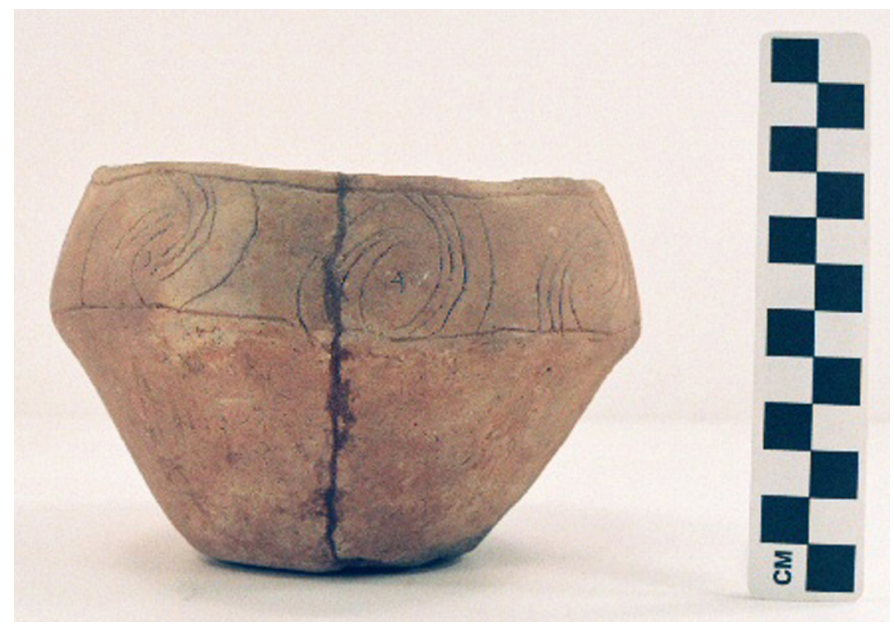

Figure 28. Patton Engraved, var. unspecified carinated bowl from the Richard Patton site.

INTERIOR SURFACE TREATMENT: smoothed on the rim

EXTERIOR SURFACE TREATMENT: smoothed on the rim

HEIGHT (IN CM): 9.5

ORIFICE DIAMETER (IN CM): 12.0

DIAMETER AT BOTTOM OF RIM OR NECK (IN CM): 14.0

BASE DIAMETER (IN CM) AND SHAPE OF BASE: 6.5; circular and flat

ESTIMATED VOLUME (IN LITERS): 0.7

DECORATION (INCLUDING MOTIF AND ELEMENTS WHEN APPARENT): The rim panel is defined by single upper and lower horizontal engraved lines. On the panel are seven sets of upper and lower curvilinear hooked arm elements (Figure 28). None of the hooked arm elements or the horizontal engraved lines at the top and bottom of the panel have tick marks.

PIGMENT USE AND LOCATION ON VESSEL: none

TYPE AND VARIETY [IF KNOWN]: Patton Engraved, var. unspecified 
SITE NAME OR SITE NUMBER: Richard Patton

VESSEL NO.: 41AN26-9

NON-PLASTICS AND PASTE: grog and hematite

VESSEL FORM: Bowl

RIM AND LIP FORM: Direct rim and rounded lip

CORE COLOR: A (fired and cooled in an oxidizing environment)

INTERIOR SURFACE COLOR: very pale brown; fire clouds on the base

EXTERIOR SURFACE COLOR: very pale brown; fire clouds on the base

WALL THICKNESS (RIM, BODY, AND BASE

IN MM): rim, $5.3 \mathrm{~mm}$

INTERIOR SURFACE TREATMENT: none

EXTERIOR SURFACE TREATMENT:

smoothed on the base

HEIGHT (IN CM): 4.0

ORIFICE DIAMETER (IN CM): 9.0

DIAMETER AT BOTTOM OF RIM OR NECK (IN CM): N/A

BASE DIAMETER (IN CM) AND SHAPE OF

BASE: 4.5; circular and flat

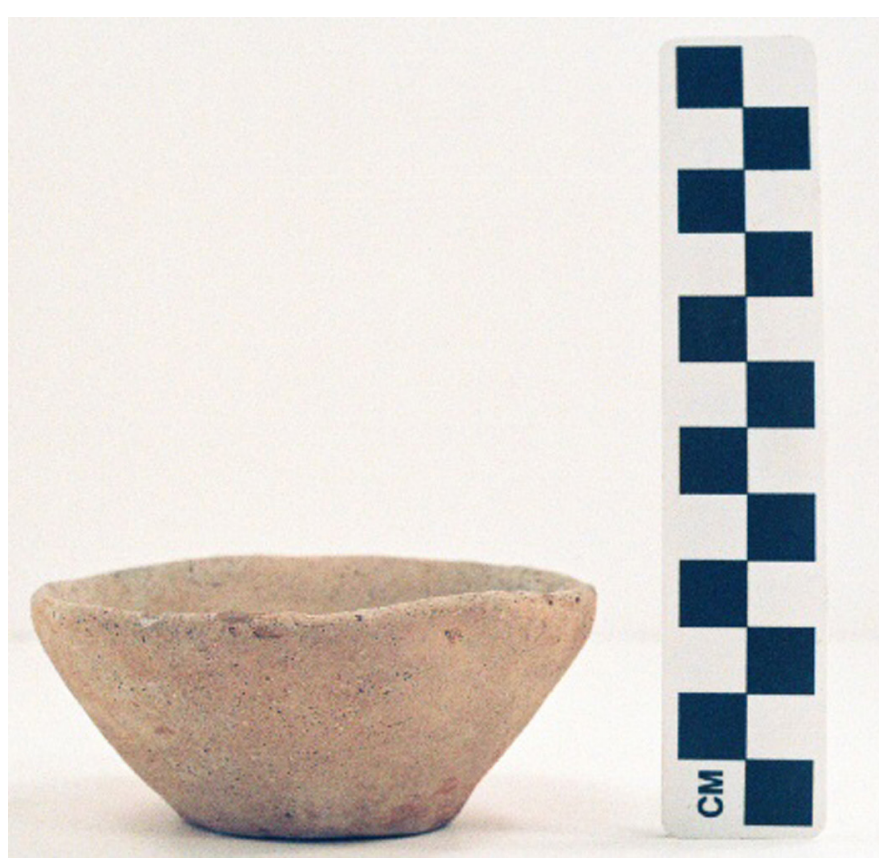

Figure 29. Plain bowl from the Richard Patton site.

ESTIMATED VOLUME (IN LITERS): 0.14

DECORATION (INCLUDING MOTIF AND ELEMENTS WHEN APPARENT): Plain (Figure 29).

PIGMENT USE AND LOCATION ON VESSEL: none

TYPE AND VARIETY [IF KNOWN]: Unidentified plain ware 
SITE NAME OR SITE NUMBER: Richard Patton

VESSEL NO.: 41AN26-10

NON-PLASTICS AND PASTE: grog and hematite

VESSEL FORM: Miniature bowl

RIM AND LIP FORM: Direct rim and rounded lip

CORE COLOR: A (fired and cooled in an oxidizing environment)

INTERIOR SURFACE COLOR: light gray

EXTERIOR SURFACE COLOR: very pale brown

WALL THICKNESS (RIM, BODY, AND BASE IN

MM): rim, $8.3 \mathrm{~mm}$

INTERIOR SURFACE TREATMENT: none

EXTERIOR SURFACE TREATMENT: none

HEIGHT (IN CM): 4.3

ORIFICE DIAMETER (IN CM): 7.5

DIAMETER AT BOTTOM OF RIM OR NECK

(IN CM): N/A

BASE DIAMETER (IN CM) AND SHAPE OF

BASE: 4.0; circular and flat
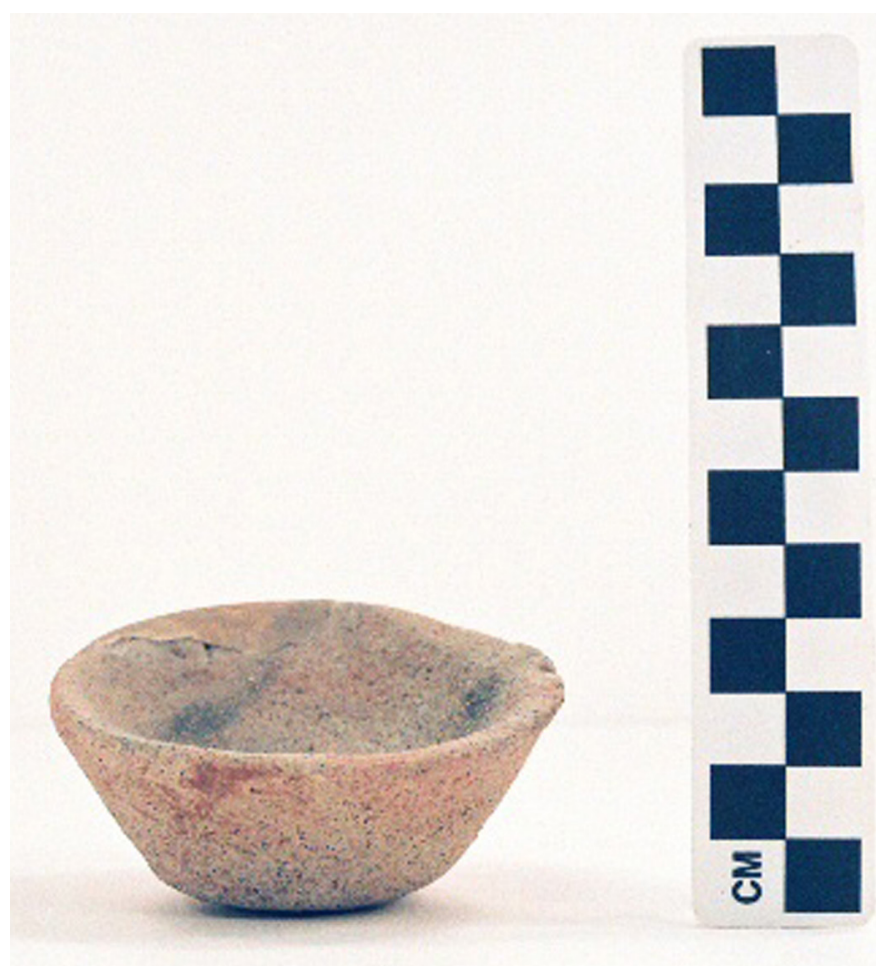

ESTIMATED VOLUME (IN LITERS): 0.13

DECORATION (INCLUDING MOTIF AND

Figure 30. Miniature plain bowl from the Richard Patton site.

ELEMENTS WHEN APPARENT): Plain (Figure $30)$.

PIGMENT USE AND LOCATION ON VESSEL: none

TYPE AND VARIETY [IF KNOWN]: Unidentified plain ware 
SITE NAME OR SITE NUMBER: Richard Patton

VESSEL NO.: 41AN26-11

NON-PLASTICS AND PASTE: grog and hematite

VESSEL FORM: Square bowl with two perforated lug handles (Figure 31)

RIM AND LIP FORM: Direct rim and rounded lip

CORE COLOR: F (fired in a reducing environment and cooled in the open air)

INTERIOR SURFACE COLOR: yellowish-brown

EXTERIOR SURFACE COLOR: brown; fire clouds on the body and base

WALL THICKNESS (RIM, BODY, AND BASE IN MM): rim, $5.3 \mathrm{~mm}$

INTERIOR SURFACE TREATMENT: smoothed on the body

EXTERIOR SURFACE TREATMENT: smoothed on the body

HEIGHT (IN CM): 8.5

ORIFICE DIAMETER (IN CM): 9.3

DIAMETER AT BOTTOM OF RIM OR NECK (IN CM): N/A

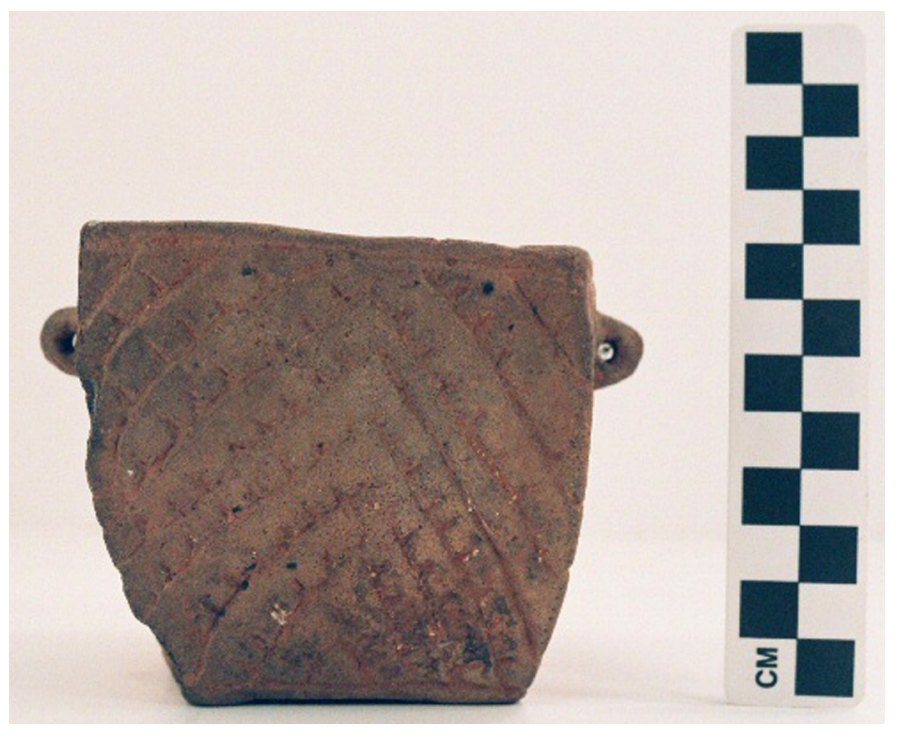

Figure 31. Patton Engraved, var. unspecified square bowl from the Richard Patton site.

BASE DIAMETER (IN CM) AND SHAPE OF BASE: 6.5; square and flat

ESTIMATED VOLUME (IN LITERS): 0.3

DECORATION (INCLUDING MOTIF AND ELEMENTS WHEN APPARENT): There are single horizontal engraved lines under the lip and just above the base of the vessel. Only on two sides of the vessel do the lines under the lip have downward-pointing excised tick marks (Figure 31). The vessel body has a series of six diagonal opposed engraved lines; on two sides the lines have excised tick marks that are upwards-pointing, while on the other two sides the tick marks point downwards. At the base of the design on each side is an engraved triangle (Figure 31). On two sides, the triangles have outward-pointing tick marks (and a smaller inner and open triangle), while the other two sides have a basal triangle element with inward-pointing tick marks.

PIGMENT USE AND LOCATION ON VESSEL: white pigment in the engraved lines

TYPE AND VARIETY [IF KNOWN]: Patton Engraved, var. unspecified (see Suhm and Jelks 1962:Plate 59c). 
SITE NAME OR SITE NUMBER: Richard Patton

VESSEL NO.: 41AN26-13

NON-PLASTICS AND PASTE: grog and hematite

VESSEL FORM: Globular bowl

RIM AND LIP FORM: Direct rim and rounded lip

CORE COLOR: $\mathrm{G}$ (fired in a reducing environment and cooled in the open air)

INTERIOR SURFACE COLOR: light yellowish-brown

EXTERIOR SURFACE COLOR: brown

WALL THICKNESS (RIM, BODY, AND BASE IN MM): body, $5.0 \mathrm{~mm}$

INTERIOR SURFACE TREATMENT: smoothed on the rim and body

EXTERIOR SURFACE TREATMENT: smoothed on the rim and body

HEIGHT (IN CM): 15.2

ORIFICE DIAMETER (IN CM): 18.0

DIAMETER AT BOTTOM OF RIM OR NECK

(IN CM): $23.5 \mathrm{~cm}$ at the widest part of the vessel body

BASE DIAMETER (IN CM) AND SHAPE OF

BASE: 8.5; circular and flat

ESTIMATED VOLUME (IN LITERS): 2.5

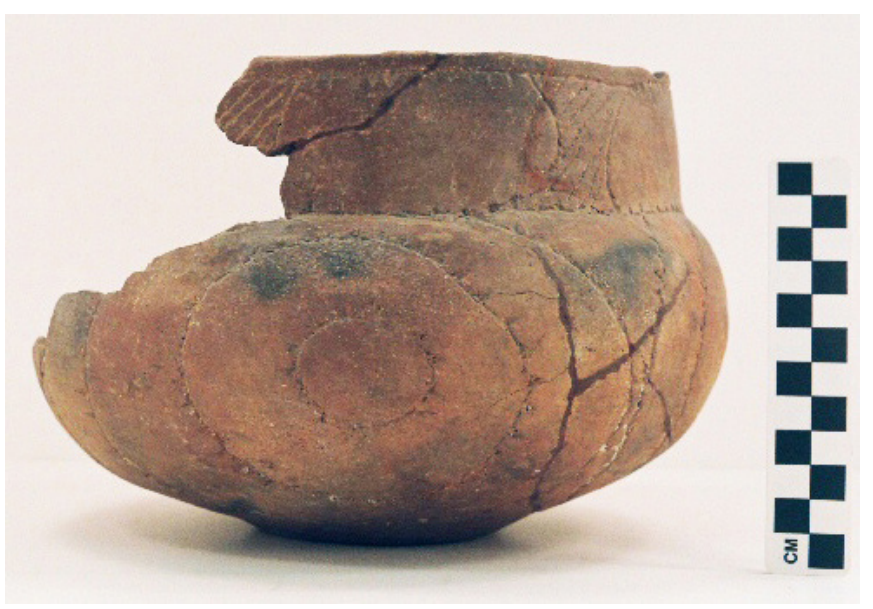

Figure 32. Patton Engraved, var. Freeman globular bowl from the Richard Patton site.

DECORATION (INCLUDING MOTIF AND ELEMENTS WHEN APPARENT): The rim panel is defined by upper and lower single horizontal lines with either downward- or upward-pointing excised tick marks (Figurer 32). The panel is divided by an unknown number of diagonal hatched brackets. The vessel body has three sets of engraved concentric circles (four concentric circles per set) with outward-pointing excised tick marks. There is also a single engraved line that extends around the base, but it does not have any tick marks.

PIGMENT USE AND LOCATION ON VESSEL: white pigment in engraved lines TYPE AND VARIETY [IF KNOWN]: Patton Engraved, var. Freeman 
SITE NAME OR SITE NUMBER: Richard Patton

VESSEL NO.: 41AN26-15

NON-PLASTICS AND PASTE: grog

VESSEL FORM: Bottle with a collared neck

RIM AND LIP FORM: N/A

CORE COLOR: $\mathrm{F}$ (fired in a reducing environment and cooled in the open air)

INTERIOR SURFACE COLOR: light yellowish-brown

EXTERIOR SURFACE COLOR: light yellowish-brown

WALL THICKNESS (RIM, BODY, AND BASE

IN MM): body, $8.0 \mathrm{~mm}$

INTERIOR SURFACE TREATMENT: none

EXTERIOR SURFACE TREATMENT:

smoothed on the body

HEIGHT (IN CM): body height is $17.5 \mathrm{~cm}$

ORIFICE DIAMETER (IN CM): N/A

DIAMETER AT BOTTOM OF RIM OR NECK

(IN CM): $20.0 \mathrm{~cm}$ at the widest point on the body

BASE DIAMETER (IN CM) AND SHAPE OF

BASE: 10.0; circular and flat

ESTIMATED VOLUME (IN LITERS): $>0.7$

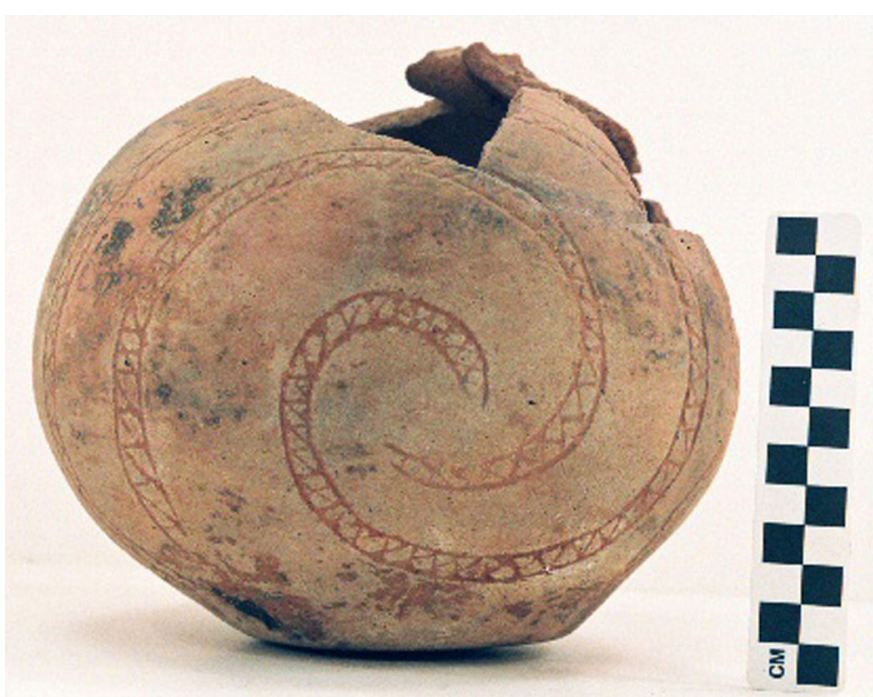

Figure 33. cf. Poynor Engraved, var. unspecified bottle from the Richard Patton site.

DECORATION (INCLUDING MOTIF AND ELEMENTS WHEN APPARENT): The vessel body has one set of cross-hatched hooked arm zones and another set of cross-hatched engraved spirals (Figure 33). These elements are divided by two intersecting diagonal cross-hatched zones.

PIGMENT USE AND LOCATION ON VESSEL: none

TYPE AND VARIETY [IF KNOWN]: cf. Poynor Engraved, var. unspecified 
SITE NAME OR SITE NUMBER: Richard Patton

VESSEL NO.: 41AN26-16

NON-PLASTICS AND PASTE: grog and hematite

VESSEL FORM: Globular Bowl

RIM AND LIP FORM: Direct rim and rounded lip

CORE COLOR: A (fired and cooled in an oxidizing environment)

INTERIOR SURFACE COLOR: light yellowish-brown

EXTERIOR SURFACE COLOR: light yellowishbrown; black film/smudging on the rim and body

WALL THICKNESS (RIM, BODY, AND BASE IN MM): rim, $5.4 \mathrm{~mm}$

INTERIOR SURFACE TREATMENT: smoothed on the rim and body

EXTERIOR SURFACE TREATMENT: smoothed on the rim and body

HEIGHT (IN CM): 11.7

ORIFICE DIAMETER (IN CM): 13.8

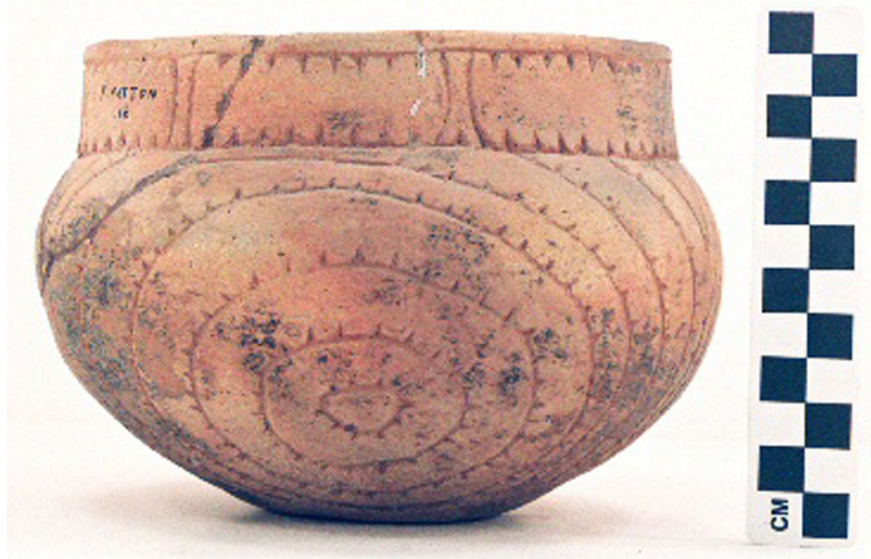

Figure 34. Patton Engraved, var. Freeman globular bowl from the Richard Patton site.

DIAMETER AT BOTTOM OF RIM OR NECK (IN CM): 14.2

BASE DIAMETER (IN CM) AND SHAPE OF BASE: 6.5; circular and flat

ESTIMATED VOLUME (IN LITERS): 1.0

DECORATION (INCLUDING MOTIF AND ELEMENTS WHEN APPARENT): The rim panel is defined by single upper and lower horizontal engraved lines that have either downward- or upward-pointing excised tick marks. The rim panel is divided by six open brackets (Figure 34). The vessel body has three sets of six engraved concentric circles, and each concentric circle has outward-pointing excised tick marks. There are open triangle elements between the upper end of each set of concentric circles.

PIGMENT USE AND LOCATION ON VESSEL: none

TYPE AND VARIETY [IF KNOWN]: Patton Engraved, var. Freeman 
SITE NAME OR SITE NUMBER: Richard Patton

VESSEL NO.: 41AN26-17

NON-PLASTICS AND PASTE: grog

VESSEL FORM: Globular bowl

RIM AND LIP FORM: Direct rim and rounded lip

CORE COLOR: $\mathrm{G}$ (fired in a reducing environment and cooled in the open air)

INTERIOR SURFACE COLOR: grayish-brown

EXTERIOR SURFACE COLOR: brown; fire clouds

WALL THICKNESS (RIM, BODY, AND BASE IN MM): $\operatorname{rim}, 5.9 \mathrm{~mm}$

INTERIOR SURFACE TREATMENT: smoothed on the rim and body

EXTERIOR SURFACE TREATMENT: burnished on the rim and smoothed on the body

HEIGHT (IN CM): 13.6

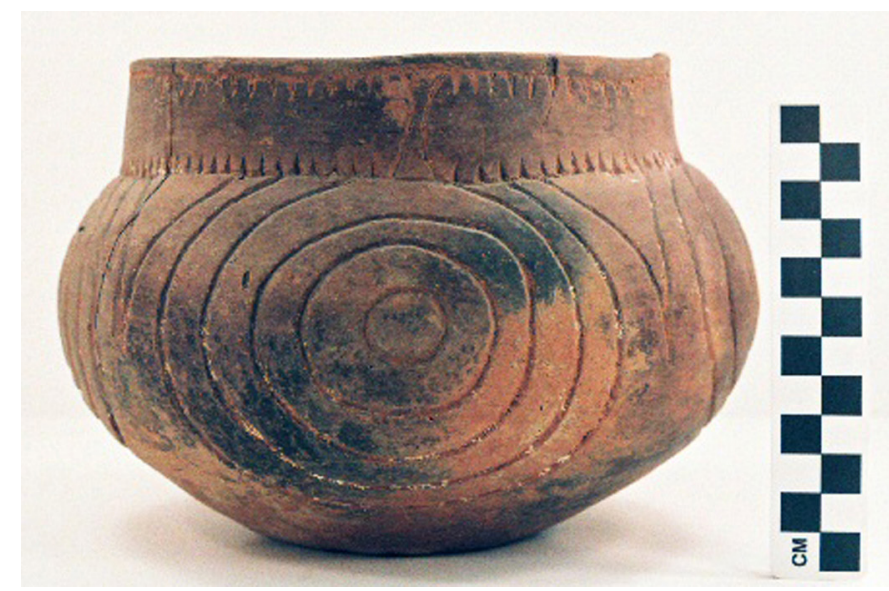

Figure 35. Poynor Engraved, var. Freeman globular bowl from the Richard Patton site.

ORIFICE DIAMETER (IN CM): 15.4

DIAMETER AT BOTTOM OF RIM OR NECK (IN CM): 15.6

BASE DIAMETER (IN CM) AND SHAPE OF BASE: 7.8; circular and flat

ESTIMATED VOLUME (IN LITERS): 1.8

DECORATION (INCLUDING MOTIF AND ELEMENTS WHEN APPARENT): The rim panel is defined by single upper and low horizontal engraved lines with upwards- and downwards-pointing excised tick marks. The rim panel is divided by four open brackets (Figure 35). The vessel body has four sets of engraved concentric circles. The concentric circles are divided at their upper end by large open pendant triangles with their apexes pointing towards the vessel base.

PIGMENT USE AND LOCATION ON VESSEL: white pigment in the engraved lines TYPE AND VARIETY [IF KNOWN]: Poynor Engraved, var. Freeman 
SITE NAME OR SITE NUMBER: Richard Patton

VESSEL NO.: 41AN26-18

NON-PLASTICS AND PASTE: grog

VESSEL FORM: Globular Bowl

RIM AND LIP FORM: Direct rim and a rounded lip

CORE COLOR: A (fired and cooled in an oxidizing environment)

INTERIOR SURFACE COLOR: very pale brown; fire clouds on the rim

EXTERIOR SURFACE COLOR: grayish-brown; black film/smudging

WALL THICKNESS (RIM, BODY, AND BASE IN MM): rim, $6.1 \mathrm{~mm}$

INTERIOR SURFACE TREATMENT: burnished on the rim and smoothed on the body

EXTERIOR SURFACE TREATMENT: burnished on the rim and smoothed on the body

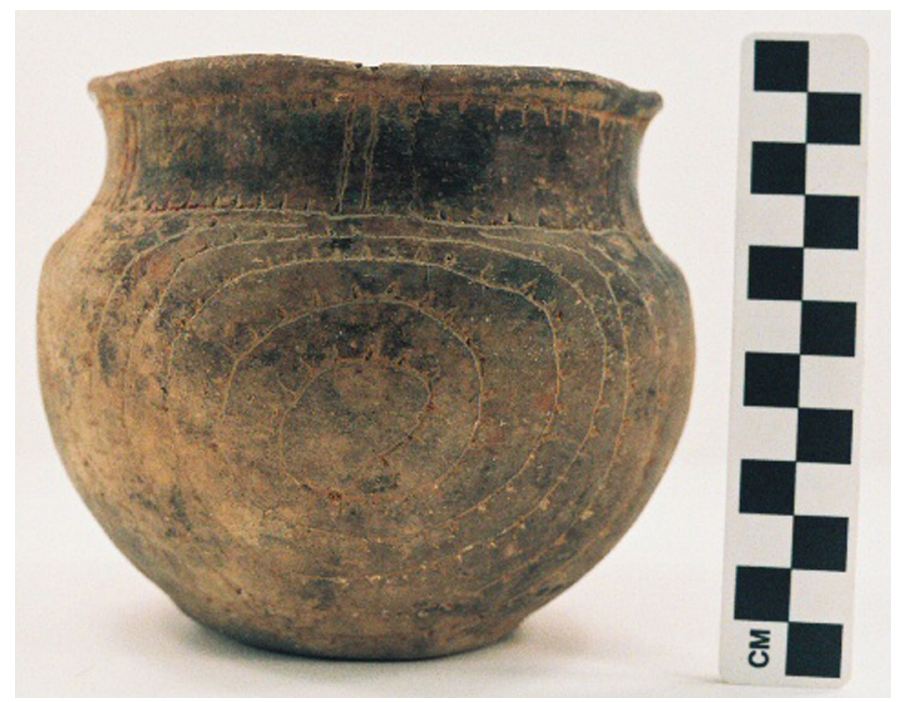

HEIGHT (IN CM): 11.8

ORIFICE DIAMETER (IN CM): 11.8

Figure 36. Patton Engraved, var. Freeman globular bowl from the Richard Patton site.

DIAMETER AT BOTTOM OF RIM OR NECK (IN CM): 10.8

BASE DIAMETER (IN CM) AND SHAPE OF BASE: 6.8; circular and flat

ESTIMATED VOLUME (IN LITERS): 0.8

DECORATION (INCLUDING MOTIF AND ELEMENTS WHEN APPARENT): The rim panel is defined by single upper and lower horizontal engraved lines with tick marks. The rim is divided into six sections by six sets of two closely-spaced vertical engraved lines (Figure 36). The vessel body has three sets of engraved concentric spirals that have outward-pointing tick marks on each spiral line. The concentric spirals are divided at their upper ends by three large open pendant triangles, one of which has tick marks on its outer lines as well as a single inner vertical engraved line (Figure 36).

PIGMENT USE AND LOCATION ON VESSEL: red pigment on engraved lines on the rim, and white pigment on engraved lines on the vessel body

TYPE AND VARIETY [IF KNOWN]: Patton Engraved, var. Freeman 
SITE NAME OR SITE NUMBER: Richard Patton

VESSEL NO.: 41AN26-19

NON-PLASTICS AND PASTE: grog

VESSEL FORM: Globular Bowl

RIM AND LIP FORM: Direct rim and rounded lip

CORE COLOR: $\mathrm{F}$ (fired in a reducing environment and cooled in the open air)

INTERIOR SURFACE COLOR: light yellowish-brown

EXTERIOR SURFACE COLOR: light brownishgray; fire clouds on the body

WALL THICKNESS (RIM, BODY, AND BASE

IN MM): rim, $4.4 \mathrm{~mm}$

INTERIOR SURFACE TREATMENT: smoothed on the rim and body

EXTERIOR SURFACE TREATMENT:

smoothed on the rim and body

HEIGHT (IN CM): 9.8

ORIFICE DIAMETER (IN CM): 12.8

DIAMETER AT BOTTOM OF RIM OR NECK (IN CM): 12.5

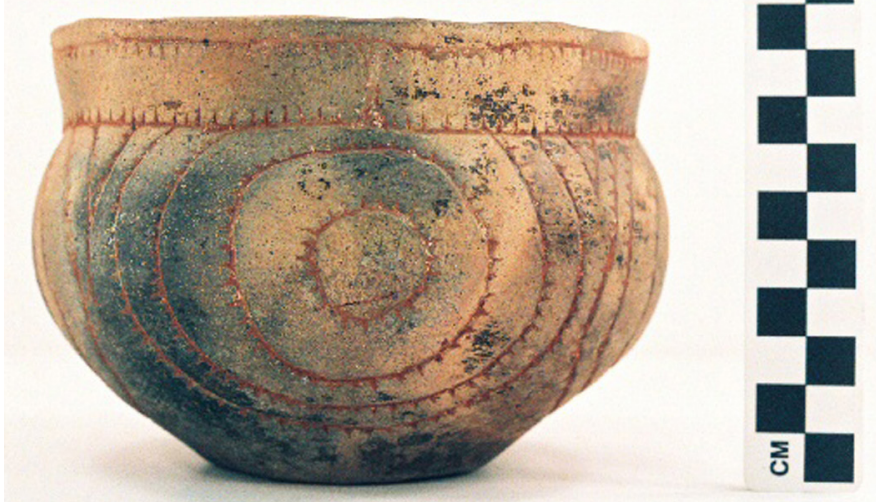

Figure 37. Patton Engraved, var. Freeman globular bowl from the Richard Patton site.

BASE DIAMETER (IN CM) AND SHAPE OF BASE: 6.2; circular and flat

ESTIMATED VOLUME (IN LITERS): 0.8

DECORATION (INCLUDING MOTIF AND ELEMENTS WHEN APPARENT): The rim panel is defined by single upper and lower horizontal engraved lines with excised tick marks that point either downwards or upwards. The panel is divided by two excised brackets and two vertical lines (Figure 37). The vessel body has four sets of concentric circles with outward-pointing tick marks. The concentric circles are divided at their upper ends by four large pendant triangles with inward-pointing tick marks on two sides of the triangles.

PIGMENT USE AND LOCATION ON VESSEL: red pigment in engraved lines

TYPE AND VARIETY [IF KNOWN]: Patton Engraved, var. Freeman 
SITE NAME OR SITE NUMBER: Richard Patton

VESSEL NO.: 41AN26-20

NON-PLASTICS AND PASTE: grog and hematite

VESSEL FORM: Globular Bowl

RIM AND LIP FORM: Direct rim and rounded lip

CORE COLOR: F (fired in a reducing environment and cooled in the open air)

INTERIOR SURFACE COLOR: light yellowish-brown

EXTERIOR SURFACE COLOR: reddish-yellow

WALL THICKNESS (RIM, BODY, AND BASE

IN MM): rim, $5.1 \mathrm{~mm}$

INTERIOR SURFACE TREATMENT: smoothed on the rim and body

EXTERIOR SURFACE TREATMENT:

smoothed on the rim and body

HEIGHT (IN CM): 10.2

ORIFICE DIAMETER (IN CM): 10.8

DIAMETER AT BOTTOM OF RIM OR NECK (IN CM): 10.2

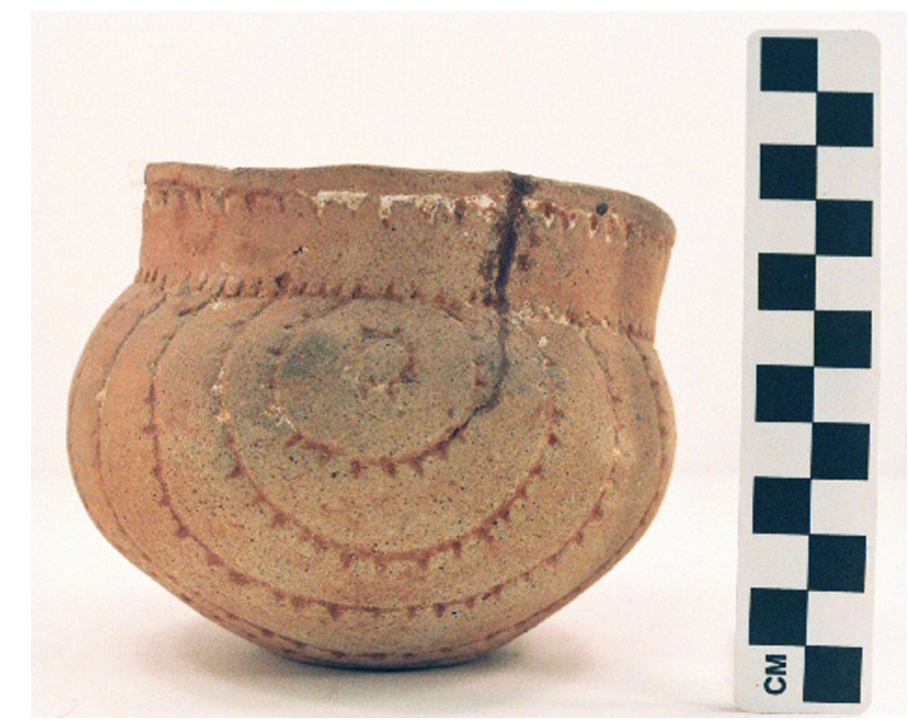

BASE DIAMETER (IN CM) AND SHAPE OF

BASE: 4.5; circular and flat

Figure 38. Patton Engraved, var. Fair globular bowl from the Richard Patton site.

ESTIMATED VOLUME (IN LITERS): 0.7

DECORATION (INCLUDING MOTIF AND ELEMENTS WHEN APPARENT): The rim has single upper and lower horizontal engraved lines with downward- or upward-pointing excised tick marks. The vessel body has two sets of engraved concentric semi-circles and circles, each line with outward-pointing tick marks (Figure 38).

PIGMENT USE AND LOCATION ON VESSEL: white pigment in the engraved lines TYPE AND VARIETY [IF KNOWN]: Patton Engraved, var. Fair 
SITE NAME OR SITE NUMBER: Richard Patton

VESSEL NO.: 41AN26-21

NON-PLASTICS AND PASTE: grog

VESSEL FORM: Globular Bowl

RIM AND LIP FORM: Direct rim and rounded lip

CORE COLOR: A (fired and cooled in an oxidizing environment)

INTERIOR SURFACE COLOR: reddish-yellow

EXTERIOR SURFACE COLOR: reddish-yellow; fire clouds

WALL THICKNESS (RIM, BODY, AND BASE

IN MM): $\operatorname{rim}, 6.3 \mathrm{~mm}$

INTERIOR SURFACE TREATMENT: smoothed on the rim and body

EXTERIOR SURFACE TREATMENT:

smoothed on the rim and body

HEIGHT (IN CM): 14.0

ORIFICE DIAMETER (IN CM): 15.2

DIAMETER AT BOTTOM OF RIM OR NECK (IN CM): 15.4

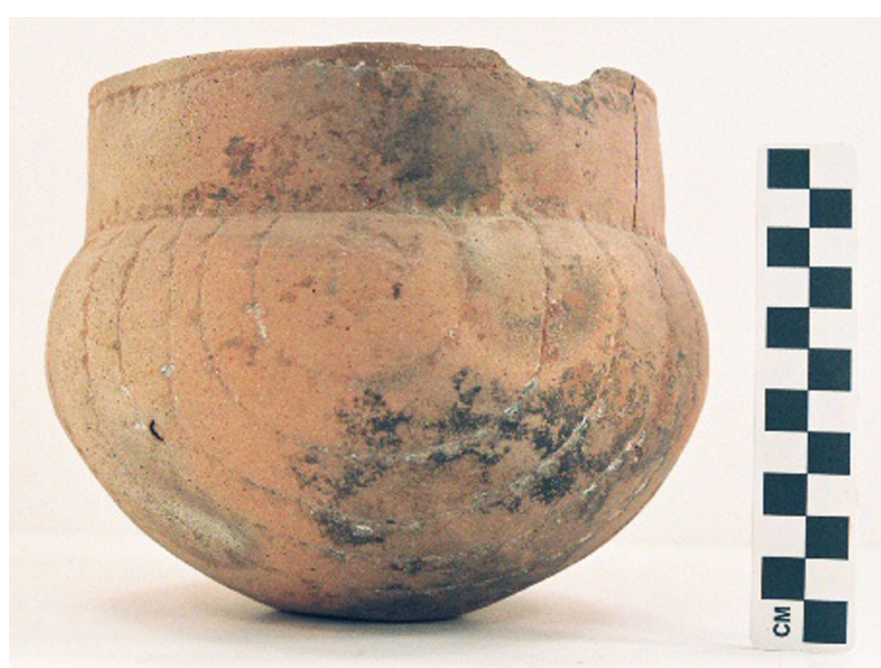

Figure 39. cf. Patton Engraved, var. Freeman globular bowl from the Richard Patton site.

BASE DIAMETER (IN CM) AND SHAPE OF BASE: 5.0; circular and flat

ESTIMATED VOLUME (IN LITERS): 1.7

DECORATION (INCLUDING MOTIF AND ELEMENTS WHEN APPARENT): The rim is divided into rectangular panels by two hatched engraved brackets. The vessel body has two sets of engraved concentric semi-circles and circles with outward-pointing triangular tick marks (Figure 39).

PIGMENT USE AND LOCATION ON VESSEL: white pigment in engraved lines

TYPE AND VARIETY [IF KNOWN]: cf. Patton Engraved, var. Freeman 
SITE NAME OR SITE NUMBER: Richard Patton

VESSEL NO.: 41AN26-22

NON-PLASTICS AND PASTE: grog and hematite

VESSEL FORM: Globular Bowl

RIM AND LIP FORM: Direct rim and rounded lip

CORE COLOR: A (fired and cooled in an oxidizing environment)

INTERIOR SURFACE COLOR: light grayishbrown; fire clouds on the rim

EXTERIOR SURFACE COLOR: light grayishbrown; fire clouds

WALL THICKNESS (RIM, BODY, AND BASE IN MM): rim, $5.5 \mathrm{~mm}$

INTERIOR SURFACE TREATMENT: smoothed on the rim and body

EXTERIOR SURFACE TREATMENT: smoothed on the rim and body

HEIGHT (IN CM): 10.2

ORIFICE DIAMETER (IN CM): 11.5

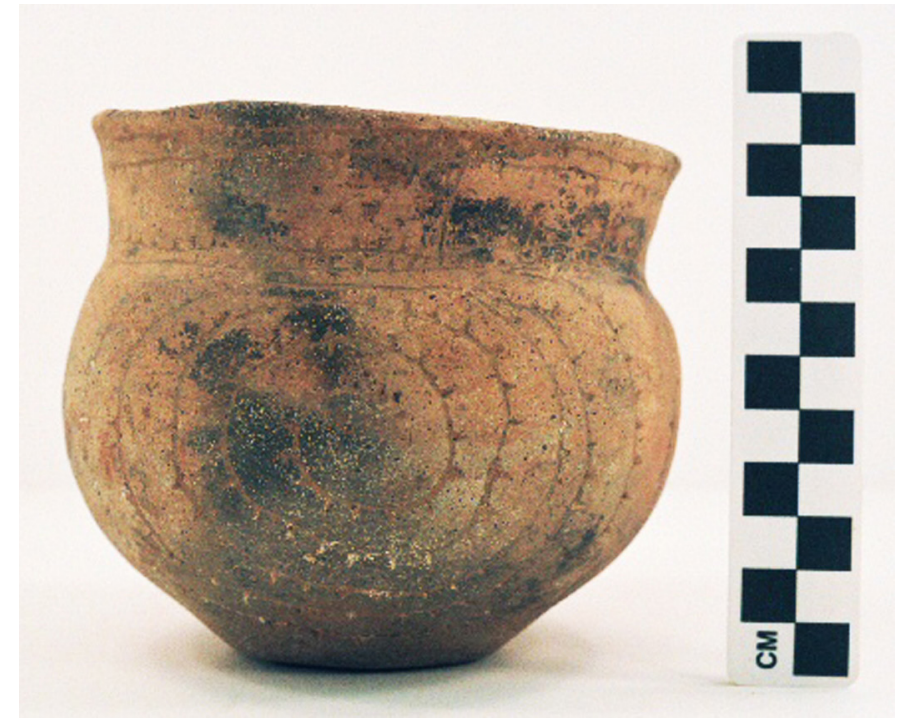

Figure 40. Patton Engraved, var. Freeman globular bowl from the Richard Patton site.

DIAMETER AT BOTTOM OF RIM OR NECK (IN CM): 10.5

BASE DIAMETER (IN CM) AND SHAPE OF BASE: 5.5; circular and flat

ESTIMATED VOLUME (IN LITERS): 0.9

DECORATION (INCLUDING MOTIF AND ELEMENTS WHEN APPARENT): The rim panel is defined by two closely-spaced sets of upper and lower horizontal engraved lines; each of the lines has either downward- or upward-pointing triangular excised tick marks (Figure 40). The rim panel is divided by two vertical engraved lines. The vessel body has two sets of concentric engraved spirals, and each concentric spiral has outward-pointing excised tick marks.

PIGMENT USE AND LOCATION ON VESSEL: white pigment in engraved lines TYPE AND VARIETY [IF KNOWN]: Patton Engraved, var. Freeman 
SITE NAME OR SITE NUMBER: Richard Patton

VESSEL NO.: 41AN26-24

NON-PLASTICS AND PASTE: grog and hematite

VESSEL FORM: Globular Bowl

RIM AND LIP FORM: Direct rim and rounded lip

CORE COLOR: F (fired in a reducing environment and cooled in the open air)

INTERIOR SURFACE COLOR: pale brown

EXTERIOR SURFACE COLOR: light brown; fire clouds

WALL THICKNESS (RIM, BODY, AND BASE

IN MM): rim, $5.5 \mathrm{~mm}$

INTERIOR SURFACE TREATMENT: burnished on the rim and smoothed on the body

EXTERIOR SURFACE TREATMENT:

smoothed on the rim and body

HEIGHT (IN CM): 10.0

ORIFICE DIAMETER (IN CM): 10.2

DIAMETER AT BOTTOM OF RIM OR NECK (IN CM): 10.3

BASE DIAMETER (IN CM) AND SHAPE OF

BASE: 5.5; circular and flat

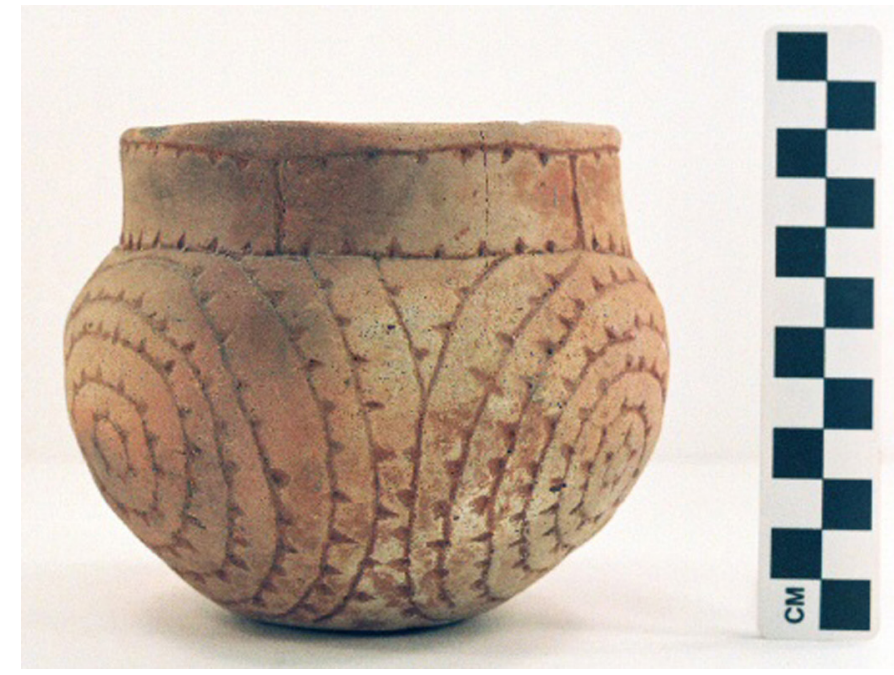

Figure 41. Patton Engraved, var. Freeman globular bowl from the Richard Patton site.

\section{ESTIMATED VOLUME (IN LITERS): 0.8}

DECORATION (INCLUDING MOTIF AND ELEMENTS WHEN APPARENT): The rim panel is defined by single upper and lower horizontal engraved lines with either downward- or upward-pointing excised tick marks. The panel is divided by six sets of vertical engraved lines (Figure 41). The vessel body has three sets of concentric circles and semi-circles, with each line having an outward-facing tick mark. The sets of concentric circles and semi-circles are divided at their upper end by three large open pendant triangles as well as a single curvilinear line that extends towards the vessel base from its beginning at the apex of the pendant triangle elements (Figure 41). There are inward-pointing tick marks on two sides of the triangles, and the curvilinear line has outward-pointing excised tick marks.

PIGMENT USE AND LOCATION ON VESSEL: white pigment in the engraved lines

TYPE AND VARIETY [IF KNOWN]: Patton Engraved, var. Freeman 
SITE NAME OR SITE NUMBER: Richard Patton

VESSEL NO.: 41AN26-26

NON-PLASTICS AND PASTE: grog

VESSEL FORM: Globular Bowl

RIM AND LIP FORM: Direct rim and rounded lip

CORE COLOR: A (fired and cooled in an oxidizing environment)

INTERIOR SURFACE COLOR: very pale brown; fire clouds on the base

EXTERIOR SURFACE COLOR: very pale brown; fire clouds on the rim, body, and base

WALL THICKNESS (RIM, BODY, AND BASE

IN MM): rim, $7.1 \mathrm{~mm}$

INTERIOR SURFACE TREATMENT: smoothed on the rim and body

EXTERIOR SURFACE TREATMENT:

smoothed on the rim and body

HEIGHT (IN CM): 11.2

ORIFICE DIAMETER (IN CM): 12.2

DIAMETER AT BOTTOM OF RIM OR NECK (IN CM): 11.5

BASE DIAMETER (IN CM) AND SHAPE OF

BASE: 5.6; circular and flat

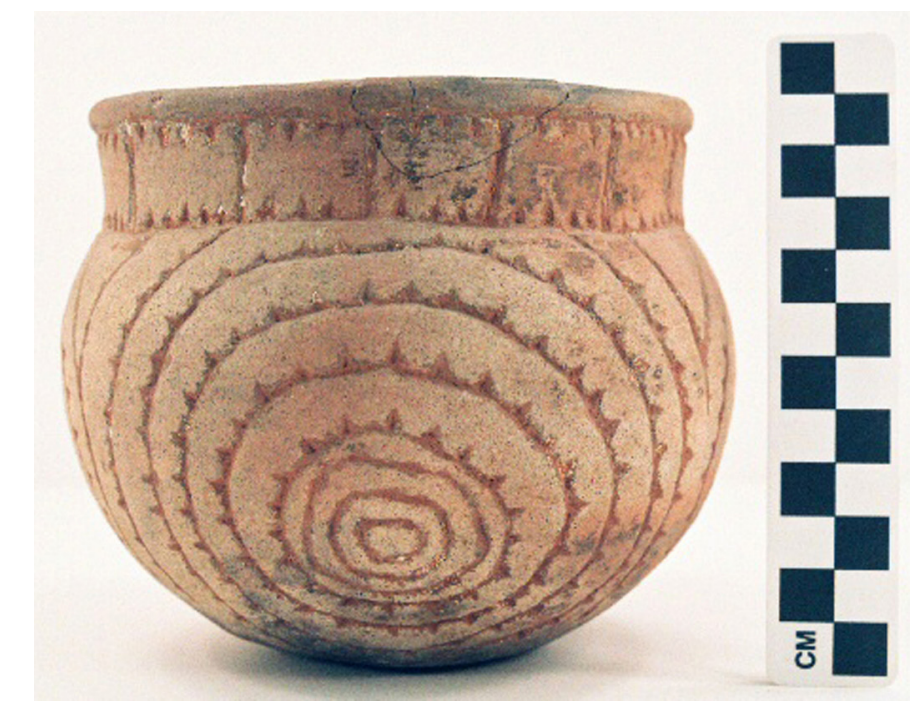

Figure 42. Patton Engraved, var. Freeman globular bowl from the Richard Patton site.

ESTIMATED VOLUME (IN LITERS): 1.1

DECORATION (INCLUDING MOTIF AND ELEMENTS WHEN APPARENT): the rim panel is defined by single upper and lower horizontal engraved lines with upwards- or downwards-pointing excised tick marks. The panel is divided into 14 rectangular areas by 14 equally-spaced vertical engraved lines (Figure 42). The vessel body has three sets of concentric circles; all but the inner three circles have outwardspointing tick marks. The sets of concentric circles are divided by large open pendant triangles by their upper ends, as well as a single curvilinear line that extends from the apex of the triangles.

PIGMENT USE AND LOCATION ON VESSEL: white pigment in engraved lines

TYPE AND VARIETY [IF KNOWN]: Patton Engraved, var. Freeman 
SITE NAME OR SITE NUMBER: Richard Patton

VESSEL NO.: 41AN26-28

NON-PLASTICS AND PASTE: grog

VESSEL FORM: Globular Bowl

RIM AND LIP FORM: Direct rim and rounded lip

CORE COLOR: B (fired and cooled in a reducing environment)

INTERIOR SURFACE COLOR: grayish-brown

EXTERIOR SURFACE COLOR: grayish-brown

WALL THICKNESS (RIM, BODY, AND BASE

IN MM): rim, $4.8 \mathrm{~mm}$

INTERIOR SURFACE TREATMENT: burnished on the rim and smoothed on the body

EXTERIOR SURFACE TREATMENT:

burnished on the body

HEIGHT (IN CM): 10.0

ORIFICE DIAMETER (IN CM): 12.5

DIAMETER AT BOTTOM OF RIM OR NECK (IN CM): 12.2

BASE DIAMETER (IN CM) AND SHAPE OF

BASE: 4.8; circular and flat

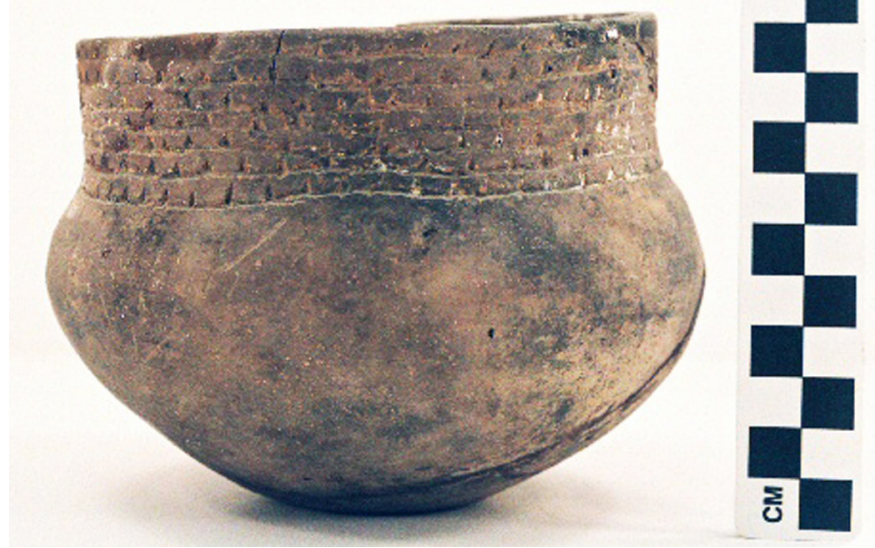

Figure 43. Patton Engraved, var. Allen globular bowl from the Richard Patton site.

ESTIMATED VOLUME (IN LITERS): 0.8

DECORATION (INCLUDING MOTIF AND ELEMENTS WHEN APPARENT): The rim has seven horizontal engraved lines, each with upwards-pointing excised tick marks (Figure 43).

PIGMENT USE AND LOCATION ON VESSEL: white pigment in engraved lines

TYPE AND VARIETY [IF KNOWN]: Patton Engraved, var. Allen 
SITE NAME OR SITE NUMBER: Richard Patton

VESSEL NO.: 41AN26-29

NON-PLASTICS AND PASTE: grog

VESSEL FORM: Globular Bowl

RIM AND LIP FORM: Direct rim and rounded lip

CORE COLOR: A (fired and cooled in an oxidizing environment)

INTERIOR SURFACE COLOR: light yellowish-brown

EXTERIOR SURFACE COLOR: light yellowish-brown

WALL THICKNESS (RIM, BODY, AND BASE

IN MM): rim, $3.6 \mathrm{~mm}$

INTERIOR SURFACE TREATMENT: smoothed on the rim and body

EXTERIOR SURFACE TREATMENT:

smoothed on the rim and body

HEIGHT (IN CM): 11.0

ORIFICE DIAMETER (IN CM): 10.6

DIAMETER AT BOTTOM OF RIM OR NECK (IN CM): 10.0

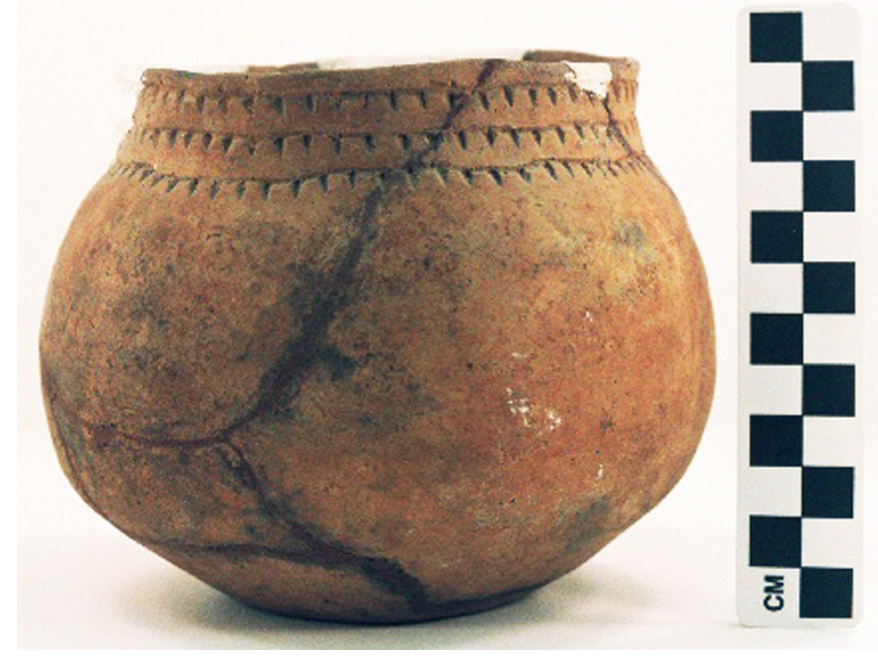

BASE DIAMETER (IN CM) AND SHAPE OF

BASE: 6.3 ; circular and flat

Figure 44. Patton Engraved, var. Allen globular bowl from the Richard Patton site.

ESTIMATED VOLUME (IN LITERS): 0.9

DECORATION (INCLUDING MOTIF AND ELEMENTS WHEN APPARENT): The rim panel has three horizontal engraved lines with downward-pointing excised tick marks (Figure 44).

PIGMENT USE AND LOCATION ON VESSEL: none

TYPE AND VARIETY [IF KNOWN]: Patton Engraved, var. Allen 
SITE NAME OR SITE NUMBER: Richard Patton

VESSEL NO.: 41AN26-30

NON-PLASTICS AND PASTE: grog

VESSEL FORM: Globular bowl

RIM AND LIP FORM: Direct rim and rounded lip

CORE COLOR: $\mathrm{F}$ (fired in a reducing environment and cooled in the open air)

INTERIOR SURFACE COLOR: light yellowish-brown

EXTERIOR SURFACE COLOR: pale brown;

black film/smudging on vessel body; fire clouds on the rim

WALL THICKNESS (RIM, BODY, AND BASE

IN MM): rim, $4.9 \mathrm{~mm}$

INTERIOR SURFACE TREATMENT: smoothed on the rim

EXTERIOR SURFACE TREATMENT:

burnished on the rim and body

HEIGHT (IN CM): 9.7

ORIFICE DIAMETER (IN CM): 12.5

DIAMETER AT BOTTOM OF RIM OR NECK (IN CM): 11.5

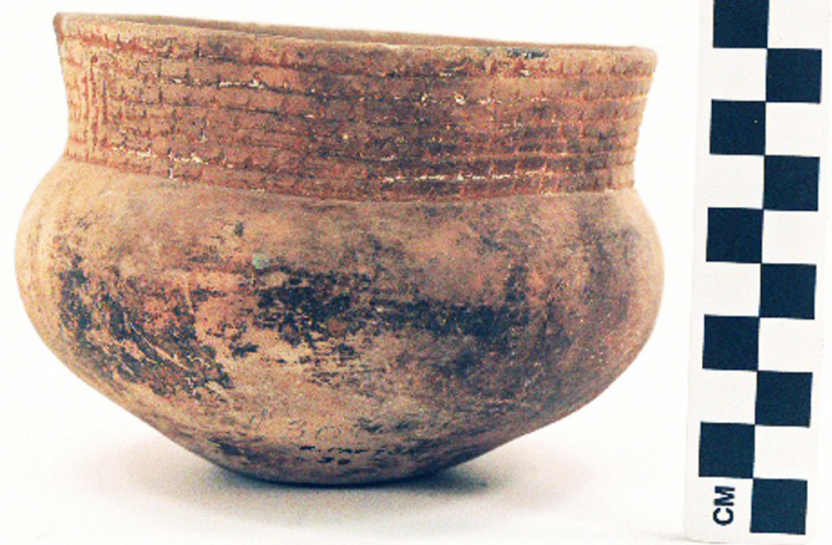

Figure 45. Patton Engraved, var. Allen globular bowl from the Richard Patton site.

BASE DIAMETER (IN CM) AND SHAPE OF BASE: 4.5; circular and flat

ESTIMATED VOLUME (IN LITERS): 0.9

DECORATION (INCLUDING MOTIF AND ELEMENTS WHEN APPARENT): The rim panel has seven horizontal engraved lines with upward-pointing excised tick marks (Figure 45). In two places, the horizontal lines end abruptly at two short vertical engraved lines that have outward-pointing tick marks; the horizontal lines begin again on the other side of the vertical engraved element.

PIGMENT USE AND LOCATION ON VESSEL: white pigment in engraved lines

TYPE AND VARIETY [IF KNOWN]: Patton Engraved, var. Allen 
SITE NAME OR SITE NUMBER: Richard Patton

VESSEL NO.: 41AN26-31

NON-PLASTICS AND PASTE: grog and hematite; fine sandy paste

VESSEL FORM: Globular Bowl

RIM AND LIP FORM: Direct rim and rounded lip

CORE COLOR: $\mathrm{G}$ (fired in a reducing environment and cooled in the open air)

INTERIOR SURFACE COLOR: brown

EXTERIOR SURFACE COLOR: reddish-yellow

WALL THICKNESS (RIM, BODY, AND BASE

IN MM): rim, $5.5 \mathrm{~mm}$

INTERIOR SURFACE TREATMENT: smoothed on the rim

EXTERIOR SURFACE TREATMENT: smoothed on the rim

HEIGHT (IN CM): 10.2

ORIFICE DIAMETER (IN CM): 11.2

DIAMETER AT BOTTOM OF RIM OR NECK (IN CM): 10.6

BASE DIAMETER (IN CM) AND SHAPE OF

BASE: 5.8; circular and flat

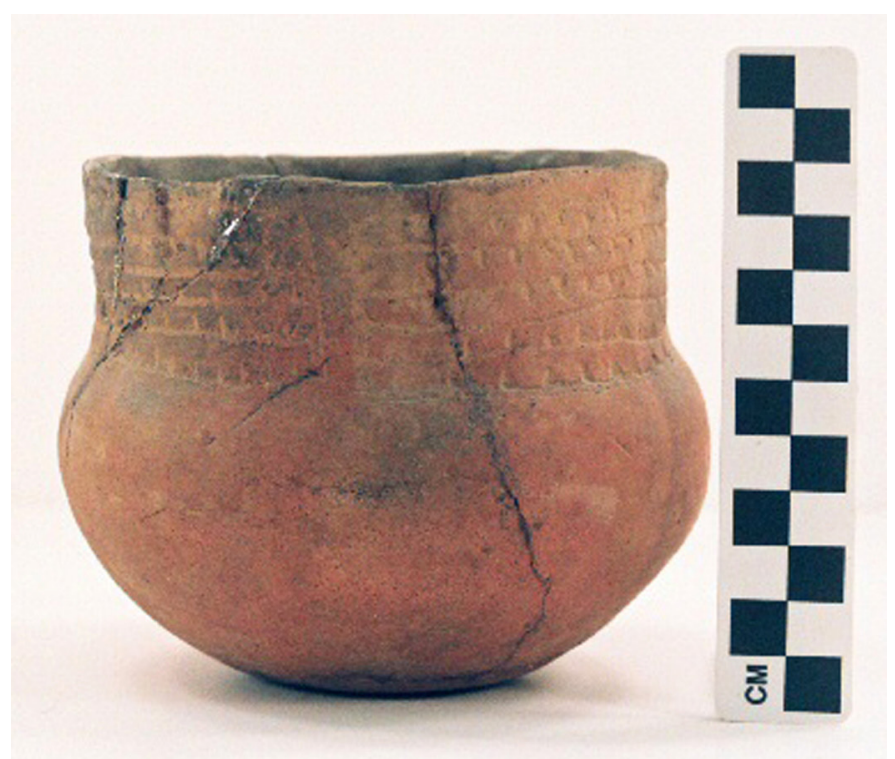

Figure 46. cf. Patton Engraved, var. Allen globular bowl from the Richard Patton site.

ESTIMATED VOLUME (IN LITERS): 0.8

DECORATION (INCLUDING MOTIF AND ELEMENTS WHEN APPARENT): The rim is divided into three rectangular panels with sets of six horizontal engraved lines (Figure 46). The horizontal lines have either upwards- or downwards-pointing excised tick marks, and one line on one of the panels has no tick marks.

PIGMENT USE AND LOCATION ON VESSEL: none

TYPE AND VARIETY [IF KNOWN]: cf. Patton Engraved, var. Allen 
SITE NAME OR SITE NUMBER: Richard Patton

VESSEL NO.: 41AN26-79

NON-PLASTICS AND PASTE: grog

VESSEL FORM: Globular Bowl

RIM AND LIP FORM: Direct rim and a rounded lip

CORE COLOR: G (fired in a reducing environment and cooled in the open air)

INTERIOR SURFACE COLOR: dark grayish-brown

EXTERIOR SURFACE COLOR: light yellowish-brown

WALL THICKNESS (RIM, BODY, AND BASE

IN MM): rim, $5.8 \mathrm{~mm}$

INTERIOR SURFACE TREATMENT: smoothed on the rim and body

EXTERIOR SURFACE TREATMENT: burnished on the rim; patches of smoothing on the body

HEIGHT (IN CM): 11.6

ORIFICE DIAMETER (IN CM): 10.0

DIAMETER AT BOTTOM OF RIM OR NECK (IN CM): 9.4

BASE DIAMETER (IN CM) AND SHAPE OF

BASE: 4.0; circular and flat

ESTIMATED VOLUME (IN LITERS): 0.9

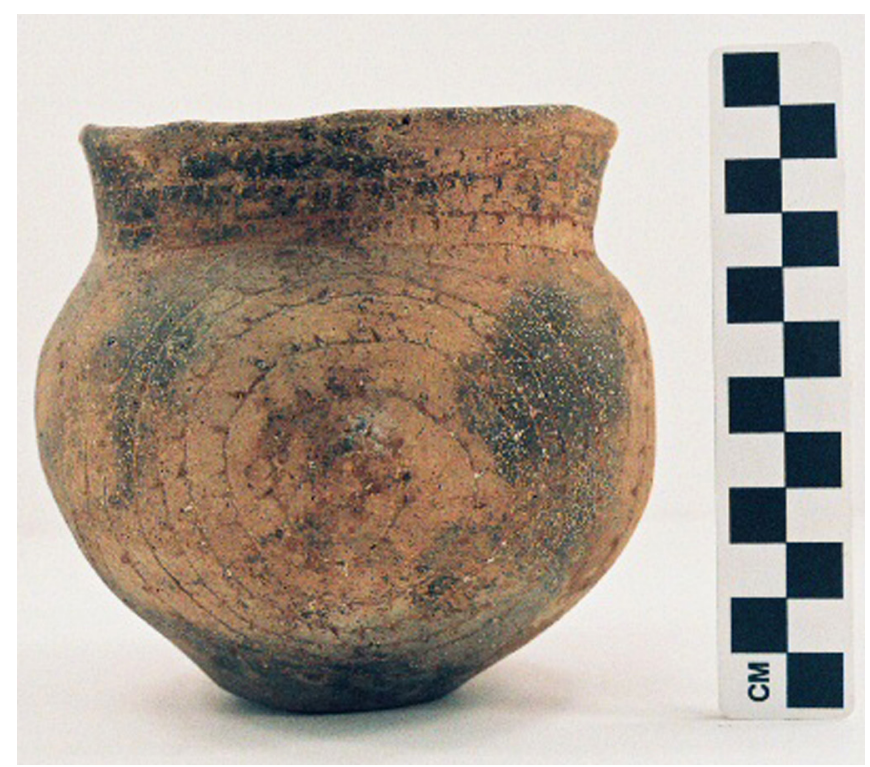

Figure 47. cf. Patton Engraved, var. Fair globular bowl from the Richard Patton site.

DECORATION (INCLUDING MOTIF AND ELEMENTS WHEN APPARENT): The rim panel has four horizontal engraved lines with downward-pointing excised tick marks; the bottom row of tick marks extends onto the vessel body (Figure 47). The vessel body has four sets of engraved concentric spirals with each line of the spirals having outward-pointing tick marks.

PIGMENT USE AND LOCATION ON VESSEL: white pigment in engraved lines TYPE AND VARIETY [IF KNOWN]: cf. Patton Engraved, var. Fair 
SITE NAME OR SITE NUMBER: Richard Patton

VESSEL NO.: 41AN26-83

NON-PLASTICS AND PASTE: grog and hematite

VESSEL FORM: Bowl with two opposed lug handles; the handles have drilled holes through the lugs (Figure 48a)

RIM AND LIP FORM: Direct rim and rounded lip

CORE COLOR: A (fired and cooled in an oxidizing environment)

INTERIOR SURFACE COLOR: pink

EXTERIOR SURFACE COLOR: brown

WALL THICKNESS (RIM, BODY, AND BASE IN $\mathrm{MM})$ : rim, $6.0 \mathrm{~mm}$

INTERIOR SURFACE TREATMENT: smoothed on the rim

EXTERIOR SURFACE TREATMENT: smoothed on the rim and body

HEIGHT (IN CM): 6.3

ORIFICE DIAMETER (IN CM): 9.0

DIAMETER AT BOTTOM OF RIM OR NECK (IN CM): N/A

BASE DIAMETER (IN CM) AND SHAPE OF BASE: 4.8; circular and flat

ESTIMATED VOLUME (IN LITERS): 0.2

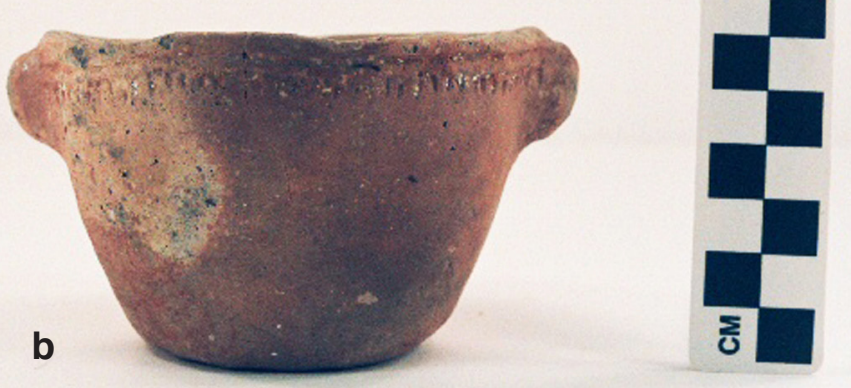

Figure 48. Patton Incised bowl from the Richard Patton site: a, view of lug handles; $b$, side view.

DECORATION (INCLUDING MOTIF AND ELEMENTS WHEN APPARENT): The rim has two horizontal incised lines. The lowermost line has linear tick marks (Figure 48b).

PIGMENT USE AND LOCATION ON VESSEL: white pigment in incised lines TYPE AND VARIETY [IF KNOWN]: Patton Incised 
SITE NAME OR SITE NUMBER: Richard Patton

VESSEL NO.: 41AN26-91

NON-PLASTICS AND PASTE: grog and hematite

VESSEL FORM: Globular Bowl

RIM AND LIP FORM: Direct rim and rounded lip

CORE COLOR: A (fired and cooled in an oxidizing environment)

INTERIOR SURFACE COLOR: light yellowish-brown

EXTERIOR SURFACE COLOR: light yellowish-brown; black film/smudging on the rim and body

WALL THICKNESS (RIM, BODY, AND BASE

IN MM): rim, $6.4 \mathrm{~mm}$

INTERIOR SURFACE TREATMENT: smoothed on the rim and body

EXTERIOR SURFACE TREATMENT:

smoothed on the rim; burnished patches on the body

HEIGHT (IN CM): 16.5

ORIFICE DIAMETER (IN CM): 16.5

DIAMETER AT BOTTOM OF RIM OR NECK (IN CM): 15.2

BASE DIAMETER (IN CM) AND SHAPE OF BASE: 7.0; circular and flat

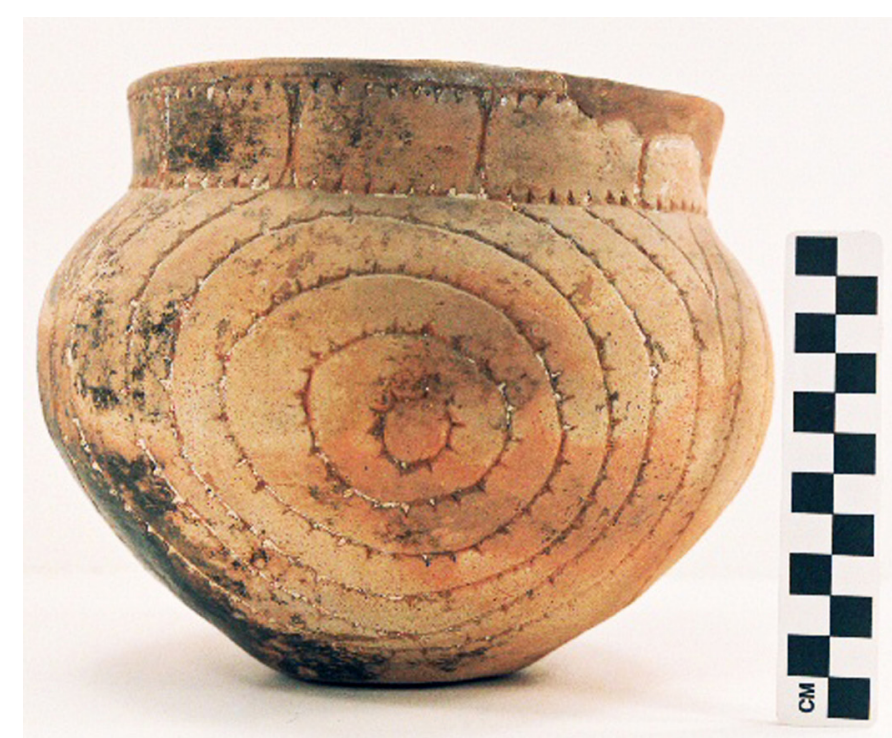

Figure 49. Patton Engraved, var. Freeman globular bowl from the Richard Patton site.

ESTIMATED VOLUME (IN LITERS): 2.2

DECORATION (INCLUDING MOTIF AND ELEMENTS WHEN APPARENT): The rim panel is defined by single upper and lower horizontal engraved lines with either upwards- or downwards-pointing excised tick marks. The panel is also divided into 10 sections by sets of excised vertical lines (Figure 49). The vessel body has three repeating sets of concentric circles and semi-circles with outward-pointing excised tick marks. These sets of concentric circles and semi-circles are divided at their upper end by large open pendant triangles with a short spur line from the apex of each triangle (Figure 49).

PIGMENT USE AND LOCATION ON VESSEL: white pigment in engraved lines 
SITE NAME OR SITE NUMBER: Richard Patton

VESSEL NO.: 41AN26-92

NON-PLASTICS AND PASTE: grog-hematite; fine sandy paste

VESSEL FORM: Globular Bowl

RIM AND LIP FORM: Direct rim and rounded lip

CORE COLOR: A (fired and cooled in an oxidizing environment)

INTERIOR SURFACE COLOR: reddish-yellow

EXTERIOR SURFACE COLOR: reddish-yellow

WALL THICKNESS (RIM, BODY, AND BASE

IN MM): rim, $4.6 \mathrm{~mm}$

INTERIOR SURFACE TREATMENT: smoothed on the rim

EXTERIOR SURFACE TREATMENT: smoothed on the rim and body; black film/smudging on the rim and body

HEIGHT (IN CM): 10.5

ORIFICE DIAMETER (IN CM): 12.2

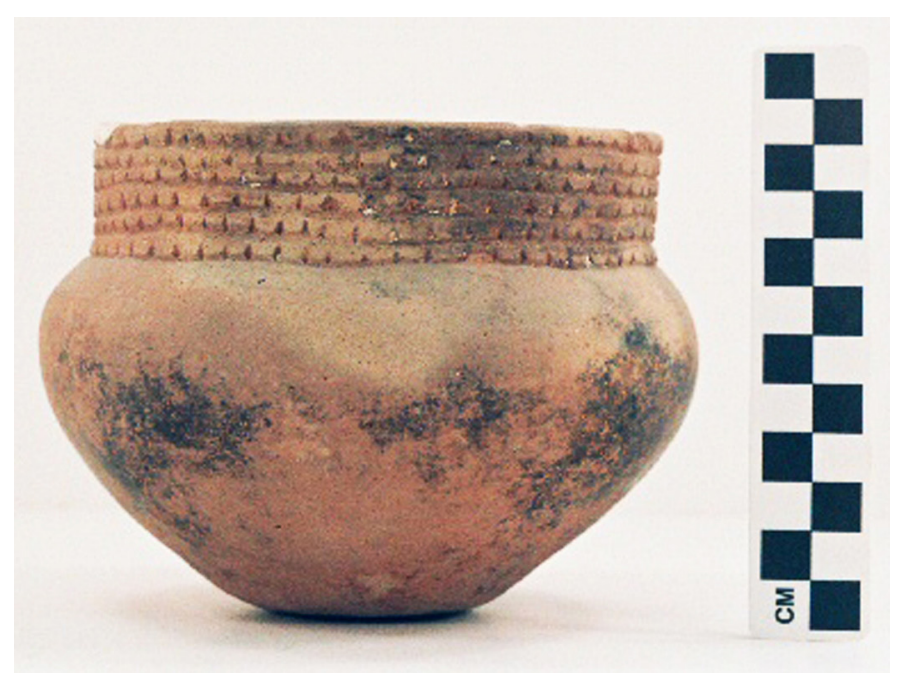

Figure 50. Patton Engraved, var. Allen globular bowl from the Richard Patton site.

DIAMETER AT BOTTOM OF RIM OR NECK (IN CM): 12.1

BASE DIAMETER (IN CM) AND SHAPE OF BASE: 4.9; circular and flat

ESTIMATED VOLUME (IN LITERS): 1.0

DECORATION (INCLUDING MOTIF AND ELEMENTS WHEN APPARENT): The rim panel has six horizontal engraved lines with upward-pointing excised tick marks on each engraved line (Figure 50).

PIGMENT USE AND LOCATION ON VESSEL: white pigment in engraved lines

TYPE AND VARIETY [IF KNOWN]: Patton Engraved, var. Allen 
SITE NAME OR SITE NUMBER: Richard Patton

VESSEL NO.: 41AN26-120

NON-PLASTICS AND PASTE: grog

VESSEL FORM: Carinated Bowl

RIM AND LIP FORM: Inverted rim and rounded lip

CORE COLOR: A (fired and cooled in an oxidizing environment)

INTERIOR SURFACE COLOR: brown

EXTERIOR SURFACE COLOR: light yellowish-brown; black film/smudging on the rim and body; fire clouds on the base

WALL THICKNESS (RIM, BODY, AND BASE

IN MM): $\operatorname{rim}, 6.5 \mathrm{~mm}$

INTERIOR SURFACE TREATMENT: smoothed on the rim and upper body

EXTERIOR SURFACE TREATMENT:

burnished on the rim

HEIGHT (IN CM): 17.6

ORIFICE DIAMETER (IN CM): 23.7

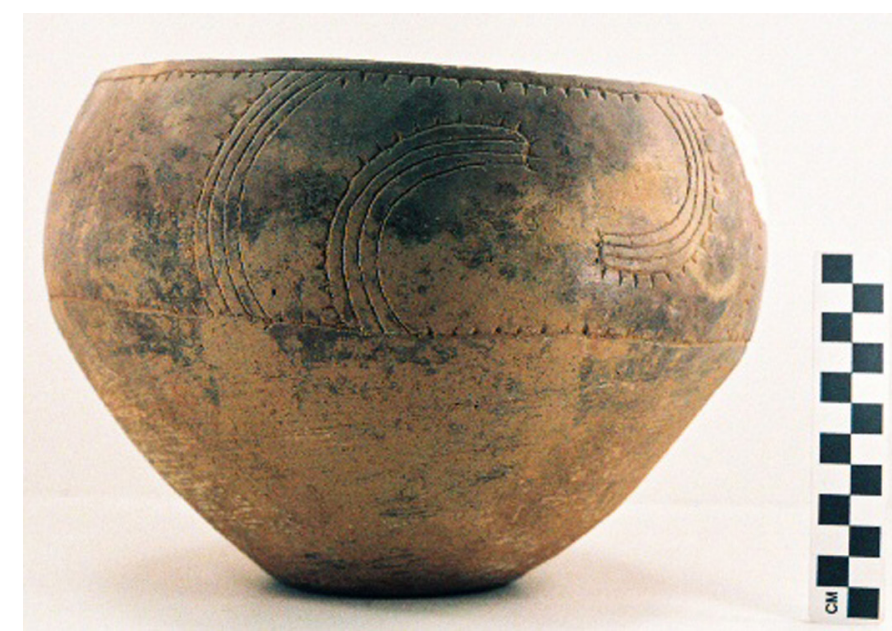

Figure 51. Patton Engraved, var. Patton carinated bowl from the Richard Patton site.

DIAMETER AT BOTTOM OF RIM OR NECK (IN CM): 23.9

BASE DIAMETER (IN CM) AND SHAPE OF BASE: 9.5; circular and flat ESTIMATED VOLUME (IN LITERS): 3.7

DECORATION (INCLUDING MOTIF AND ELEMENTS WHEN APPARENT): The rim panel is defined by single upper and lower horizontal engraved lines with either downward- or upward-pointing excised tick marks. On the panel are three sets of hooked arm elements, each with four curvilinear engraved lines; the outermost line has outward-pointing tick marks (Figure 51). The hooked arm elements are divided by three sets of four closely-spaced near vertical and arcing engraved lines; the outermost line has outward-pointing tick marks. The vessel body has horizontal and overlapping brushing marks.

PIGMENT USE AND LOCATION ON VESSEL: none

TYPE AND VARIETY [IF KNOWN]: Patton Engraved, var. Patton 
SITE NAME OR SITE NUMBER: Richard Patton

VESSEL NO.: 41AN26-121

NON-PLASTICS AND PASTE: grog

VESSEL FORM: Globular Bowl

RIM AND LIP FORM: Direct rim and rounded lip

CORE COLOR: A (fired and cooled in an oxidizing environment)

INTERIOR SURFACE COLOR: very pale brown

EXTERIOR SURFACE COLOR: very pale brown; black film/smudging on the vessel body

WALL THICKNESS (RIM, BODY, AND BASE IN MM): rim, 5.4 mm

INTERIOR SURFACE TREATMENT: smoothed on the rim and upper body

EXTERIOR SURFACE TREATMENT: smoothed on the rim and body

HEIGHT (IN CM): 10.4

ORIFICE DIAMETER (IN CM): 12.2

DIAMETER AT BOTTOM OF RIM OR NECK (IN CM): 12.2

BASE DIAMETER (IN CM) AND SHAPE OF

BASE: 6.0; circular and flat

ESTIMATED VOLUME (IN LITERS): 1.0

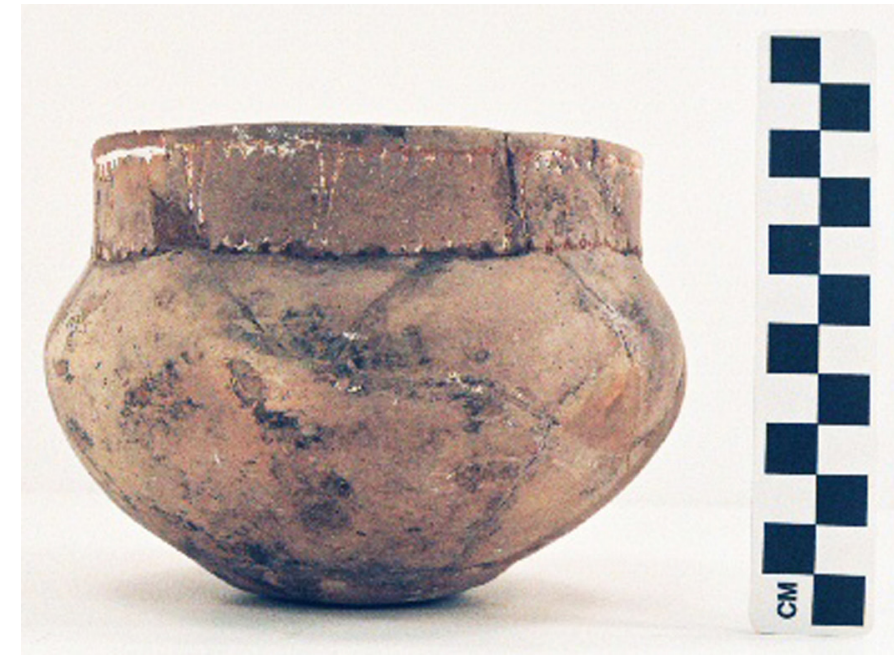

Figure 52. Poynor Engraved, var. Freeman globular bowl from the Richard Patton site.

DECORATION (INCLUDING MOTIF AND ELEMENTS WHEN APPARENT): The rim panel is defined by single upper and lower horizontal engraved lines with either upward- or downward-pointing excised tick marks. The panel is divided into 11 sections by excised brackets (Figure 52).

PIGMENT USE AND LOCATION ON VESSEL: white pigment in engraved lines

TYPE AND VARIETY [IF KNOWN]: Poynor Engraved, var. Freeman 


\section{Pierce Freeman Site (41AN34) Vessels}

The Pierce Freeman site is a small Caddo cemetery excavated by UT in 1931; the landowner had first found the site in 1914 (Cole 1975:89). Twenty ceramic vessels were among the funerary objects from the four excavated burials; there were no European trade goods recovered from the site (Marceaux 2011:424).

SITE NAME OR SITE NUMBER: Pierce Freeman

VESSEL NO.: 41AN34-1

NON-PLASTICS AND PASTE: hematite

VESSEL FORM: Bottle with a long, narrow, cylindrical body

RIM AND LIP FORM: N/A

CORE COLOR: $\mathrm{G}$ (fired in a reducing environment and cooled in the open air)

INTERIOR SURFACE COLOR: dark grayish-brown

EXTERIOR SURFACE COLOR: yellow

WALL THICKNESS (RIM, BODY, AND BASE IN

MM): neck, $8.7 \mathrm{~mm}$

INTERIOR SURFACE TREATMENT: none

EXTERIOR SURFACE TREATMENT: none

HEIGHT (IN CM): 20.7+

ORIFICE DIAMETER (IN CM): 5.8

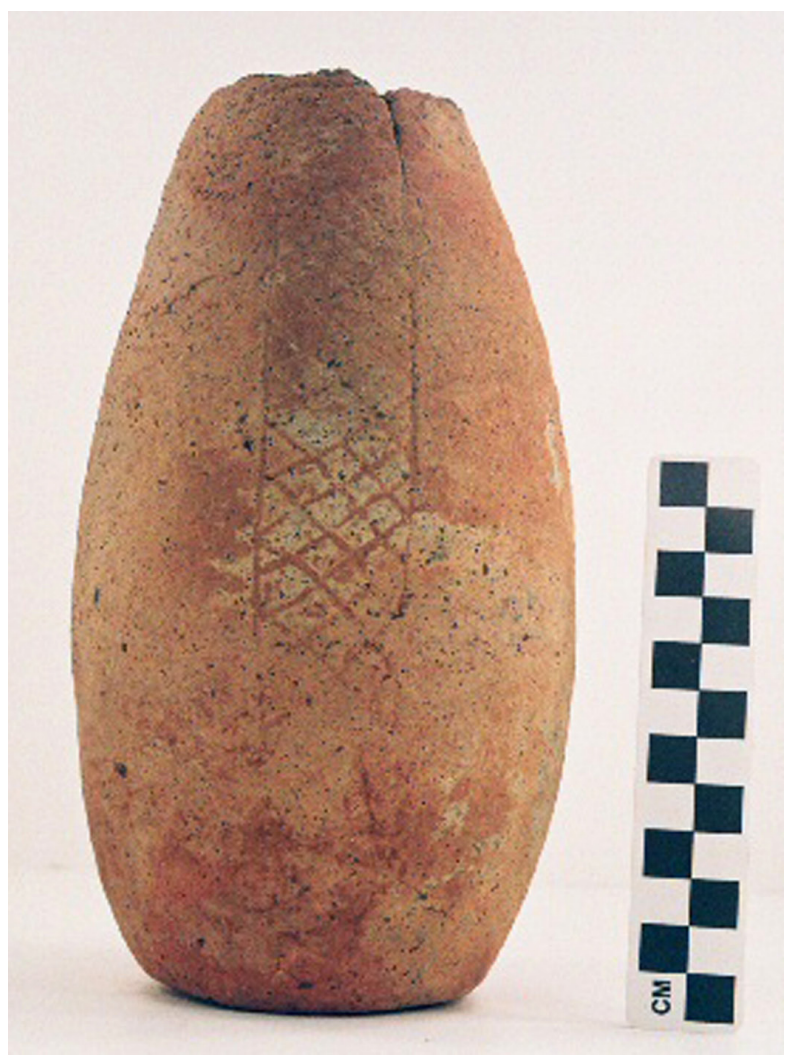

Figure 53. Hume Engraved, var. Hume bottle from the Pierce Freeman site.

DIAMETER AT BOTTOM OF RIM OR NECK (IN CM): N/A; $10.4 \mathrm{~cm}$ wide at its widest point

BASE DIAMETER (IN CM) AND SHAPE OF BASE: 7.3; circular and flat

ESTIMATED VOLUME (IN LITERS): >0.6

DECORATION (INCLUDING MOTIF AND ELEMENTS WHEN APPARENT): The vessel body has vertical panels repeated four times that are filled with cross-hatched engraved lines (Figure 53); the panels begin at a single horizontal engraved line below the bottle neck. The panels extend more than halfway down the vessel body

PIGMENT USE AND LOCATION ON VESSEL: none

TYPE AND VARIETY [IF KNOWN]: Hume Engraved, var. Hume 
SITE NAME OR SITE NUMBER: Pierce Freeman

VESSEL NO.: 41AN34-4; Burial D-1

NON-PLASTICS AND PASTE: grog and hematite

VESSEL FORM: Jar with two opposed lug handles

RIM AND LIP FORM: Direct rim and rounded lip

CORE COLOR: $\mathrm{G}$ (fired in a reducing environment and cooled in the open air)

INTERIOR SURFACE COLOR: dark grayish-brown

EXTERIOR SURFACE COLOR: strong brown to light pink

WALL THICKNESS (RIM, BODY, AND BASE IN $\mathrm{MM})$ : $\mathrm{rim}, 5.9 \mathrm{~mm}$

INTERIOR SURFACE TREATMENT: smoothed on the rim

EXTERIOR SURFACE TREATMENT: none

HEIGHT (IN CM): 13.1

ORIFICE DIAMETER (IN CM): 10.8

DIAMETER AT BOTTOM OF RIM OR NECK (IN CM): 10.8

BASE DIAMETER (IN CM) AND SHAPE OF

BASE: 5.2; circular and flat

ESTIMATED VOLUME (IN LITERS): 0.9

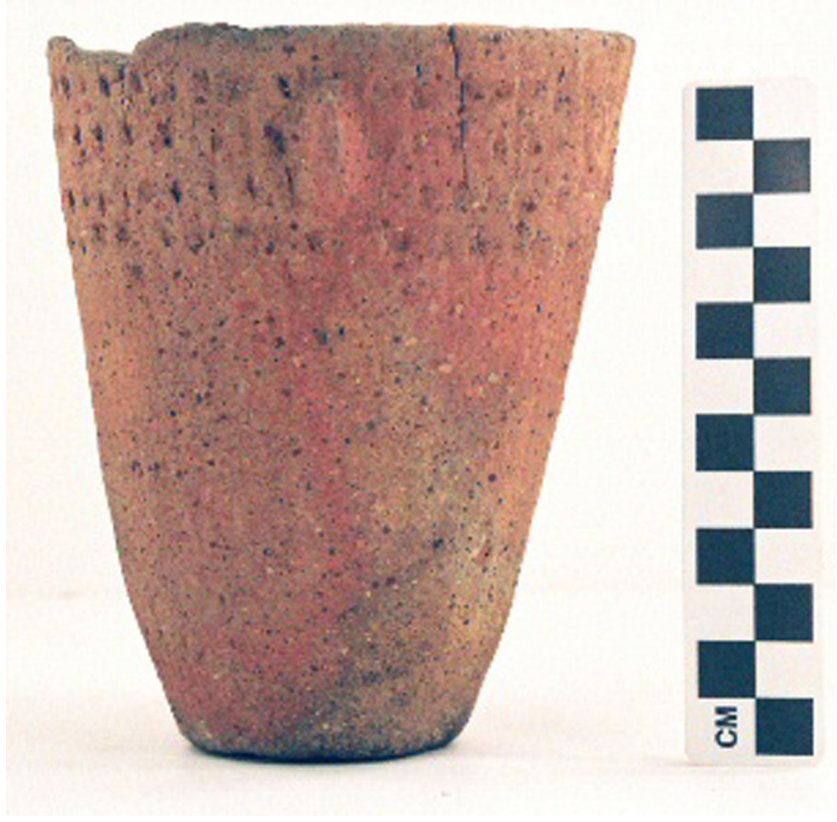

Figure 54. Bullard Brushed jar from the Pierce Freeman site.

DECORATION (INCLUDING MOTIF AND ELEMENTS WHEN APPARENT): The vessel rim and body have vertical brushing marks. There are also four rows of tool punctations on the rim, pushed through the brushing (Figure 54).

PIGMENT USE AND LOCATION ON VESSEL: none

TYPE AND VARIETY [IF KNOWN]: Bullard Brushed 
SITE NAME OR SITE NUMBER: Pierce Freeman

VESSEL NO.: 41AN34-5; Burial D-1

NON-PLASTICS AND PASTE: grog and hematite; fine sandy paste

VESSEL FORM: Carinated Bowl

RIM AND LIP FORM: Inverted rim and rounded lip

CORE COLOR: A (fired and cooled in an oxidizing environment)

INTERIOR SURFACE COLOR: very pale brown; fire clouds on the lower body and base

EXTERIOR SURFACE COLOR: very pale brown

WALL THICKNESS (RIM, BODY, AND

BASE IN MM): rim, $7.0 \mathrm{~mm}$

INTERIOR SURFACE TREATMENT:

smoothed on the rim

EXTERIOR SURFACE TREATMENT:

smoothed on the rim

HEIGHT (IN CM): 17.8

ORIFICE DIAMETER (IN CM): 27.2

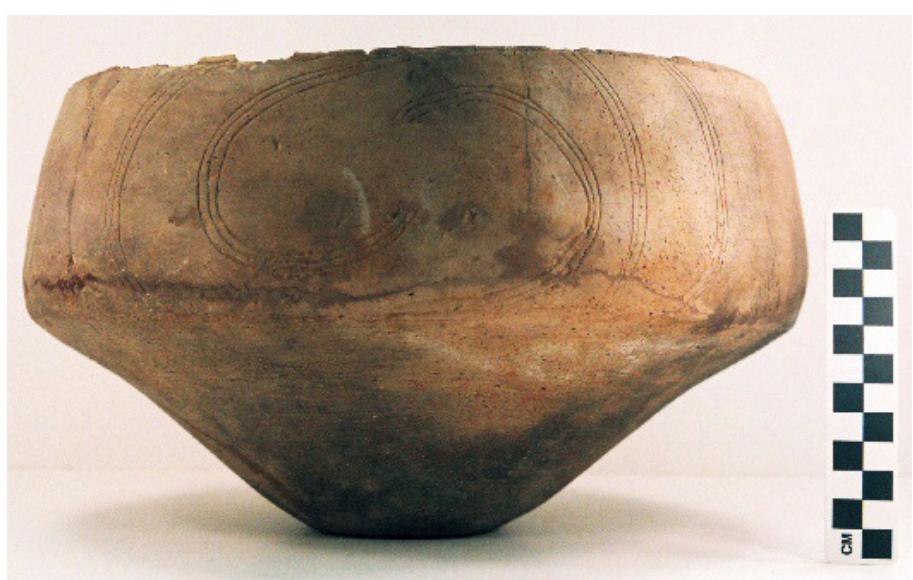

Figure 55. Poynor Engraved, var. $N$ carinated bowl from the Pierce Freeman site.

DIAMETER AT BOTTOM OF RIM OR NECK (IN CM): 32.8

BASE DIAMETER (IN CM) AND SHAPE OF BASE: 7.2; circular and flat

ESTIMATED VOLUME (IN LITERS): 4.4

DECORATION (INCLUDING MOTIF AND ELEMENTS WHEN APPARENT): The rim is divided into four rectangular panels by brackets with upper and lower cross-hatched engraved triangles (Figure 55). Within the panels are curvilinear hooked arm elements comprised of upper and lower sets of three engraved lines, as well as opposed sets of three closely-spaced curvilinear engraved lines. The vessel body has overlapping brushing marks on it.

PIGMENT USE AND LOCATION ON VESSEL: none

TYPE AND VARIETY [IF KNOWN]: Poynor Engraved, var. N (see Figure 4) 
SITE NAME OR SITE NUMBER: Pierce Freeman

VESSEL NO.: 41AN34-6; Burial D-1

NON-PLASTICS AND PASTE: grog

VESSEL FORM: Globular Bowl

RIM AND LIP FORM: Everted rim and rounded lip

CORE COLOR: A (fired and cooled in an oxidizing environment)

INTERIOR SURFACE COLOR: brownishyellow; fire clouds on the base

EXTERIOR SURFACE COLOR: brownishyellow; fire clouds on the rim, body, and base

WALL THICKNESS (RIM, BODY, AND BASE IN MM): rim, $7.0 \mathrm{~mm}$

INTERIOR SURFACE TREATMENT: none

EXTERIOR SURFACE TREATMENT: smoothed on the rim and body

HEIGHT (IN CM): 12.8

ORIFICE DIAMETER (IN CM): 14.4

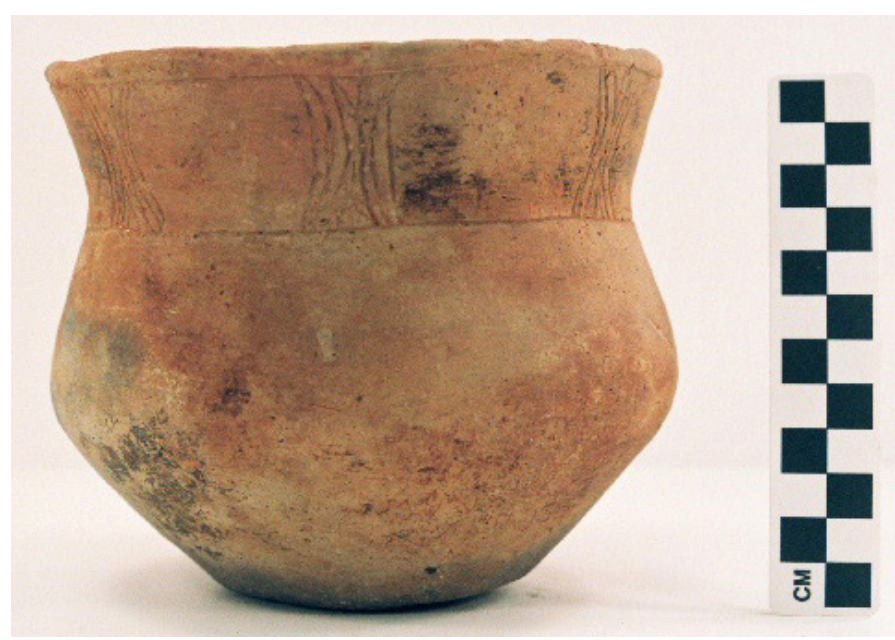

Figure 56. Poynor Engraved, var. Hood globular bowl from the Pierce Freeman site.

DIAMETER AT BOTTOM OF RIM OR NECK (IN CM): 12.1

BASE DIAMETER (IN CM) AND SHAPE OF BASE: 7.7; circular and flat

ESTIMATED VOLUME (IN LITERS): 1.5

DECORATION (INCLUDING MOTIF AND ELEMENTS WHEN APPARENT): The rim panel is defined by single upper and lower horizontal engraved lines. The panel itself is divided into seven negative ovals by brackets filled with opposed near-vertical arcing engraved lines (Figure 56).

PIGMENT USE AND LOCATION ON VESSEL: none

TYPE AND VARIETY [IF KNOWN]: Poynor Engraved, var. Hood 
SITE NAME OR SITE NUMBER: Pierce Freeman

VESSEL NO.: 41AN34-7; Burial D-1

NON-PLASTICS AND PASTE: grog and hematite

VESSEL FORM: Carinated Bowl

RIM AND LIP FORM: Direct rim and rounded lip

CORE COLOR: $\mathrm{F}$ (fired in a reducing environment and cooled in the open air)

INTERIOR SURFACE COLOR: yellow

EXTERIOR SURFACE COLOR: yellow; fire clouds on the rim and body

WALL THICKNESS (RIM, BODY, AND

BASE IN MM): rim, $5.0 \mathrm{~mm}$

INTERIOR SURFACE TREATMENT:

smoothed on the rim

EXTERIOR SURFACE TREATMENT:

burnished on the rim and body

HEIGHT (IN CM): 7.3

ORIFICE DIAMETER (IN CM): 12.0

DIAMETER AT BOTTOM OF RIM OR NECK (IN CM): 12.0

BASE DIAMETER (IN CM) AND SHAPE OF

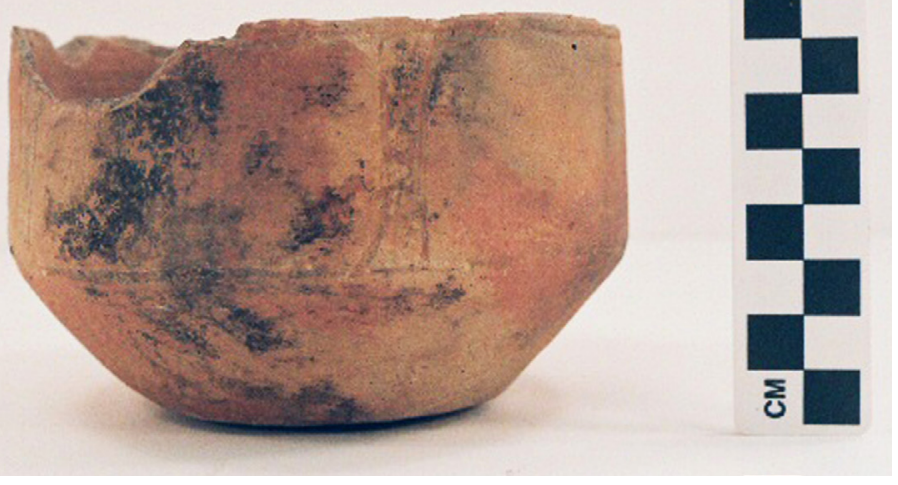

Figure 57. Poynor Engraved, var. Hood carinated bowl from the Pierce Freeman site.

BASE: 6.4 ; circular and flat

ESTIMATED VOLUME (IN LITERS): 0.5

DECORATION (INCLUDING MOTIF AND ELEMENTS WHEN APPARENT): the rim panel is defined by single upper and lower horizontal engraved lines. The panel is divided into four rectangular sections by excised brackets and vertical columns (Figure 57).

PIGMENT USE AND LOCATION ON VESSEL: none

TYPE AND VARIETY [IF KNOWN]: Poynor Engraved, var. Hood 
SITE NAME OR SITE NUMBER: Pierce Freeman

VESSEL NO.: 41AN34-8; Burial D-1

NON-PLASTICS AND PASTE: grog and hematite

VESSEL FORM: Globular Bowl

RIM AND LIP FORM: Direct rim and a rounded lip

CORE COLOR: A (fired and cooled in an oxidizing environment)

INTERIOR SURFACE COLOR: reddish-yellow

EXTERIOR SURFACE COLOR: reddish-yellow

WALL THICKNESS (RIM, BODY, AND BASE

IN MM): rim, $5.6 \mathrm{~mm}$

INTERIOR SURFACE TREATMENT: smoothed on the rim

EXTERIOR SURFACE TREATMENT:

smoothed on the rim; black film/smudging on the rim and body

HEIGHT (IN CM): 14.4

ORIFICE DIAMETER (IN CM): 16.0

DIAMETER AT BOTTOM OF RIM OR NECK (IN CM): 14.2

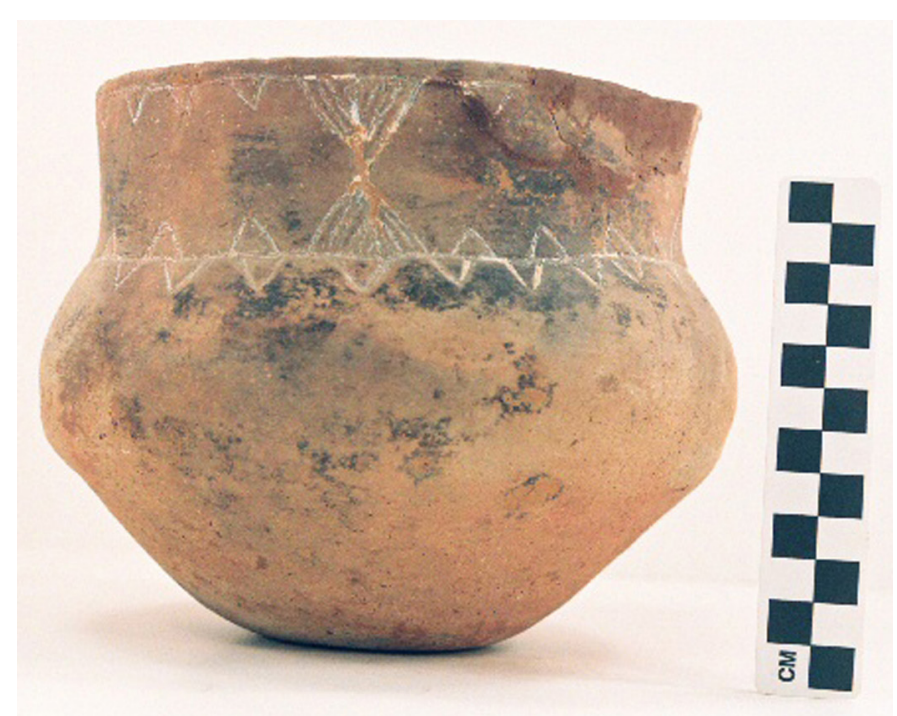

Figure 58. Poynor Engraved, var. unspecified globular bowl from the Pierce Freeman site.

BASE DIAMETER (IN CM) AND SHAPE OF BASE: 6.7; circular and flat

ESTIMATED VOLUME (IN LITERS): 1.8

DECORATION (INCLUDING MOTIF AND ELEMENTS WHEN APPARENT): The rim panel is defined by single upper and lower horizontal engraved lines. There are four sets of large upper and lower hatched pendant triangles in the panel as well as three rows of large open pendant engraved triangles pointing either upwards or downwards (Figure 58); the lowermost row of open pendant triangles extends onto the upper vessel body.

PIGMENT USE AND LOCATION ON VESSEL: white pigment in engraved lines

TYPE AND VARIETY [IF KNOWN]: Poynor Engraved, var. unspecified 
SITE NAME OR SITE NUMBER: Pierce Freeman

VESSEL NO.: 41AN34-9; Burial D-1

NON-PLASTICS AND PASTE: grog and hematite

VESSEL FORM: Globular Bowl

RIM AND LIP FORM: Direct rim and rounded lip

CORE COLOR: A (fired and cooled in an oxidizing environment)

INTERIOR SURFACE COLOR: very pale brown

EXTERIOR SURFACE COLOR: very pale brown; fire clouds on the rim and body

WALL THICKNESS (RIM, BODY, AND BASE

IN MM): rim, $8.2 \mathrm{~mm}$

INTERIOR SURFACE TREATMENT: none

EXTERIOR SURFACE TREATMENT:

smoothed on the body

HEIGHT (IN CM): 14.8

ORIFICE DIAMETER (IN CM): 15.2

DIAMETER AT BOTTOM OF RIM OR NECK (IN CM): 15.0

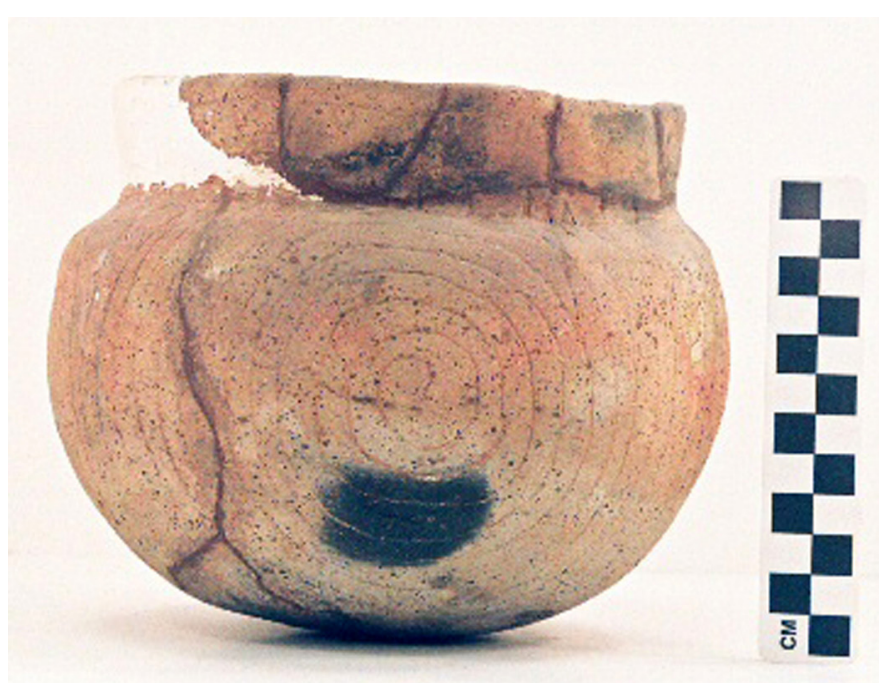

Figure 59. Poynor Engraved, var. Freeman globular bowl from the Pierce Freeman site.

BASE DIAMETER (IN CM) AND SHAPE OF BASE: N/A; circular and rounded base

ESTIMATED VOLUME (IN LITERS): 1.8

DECORATION (INCLUDING MOTIF AND ELEMENTS WHEN APPARENT): The rim panel has single upper and lower horizontal engraved lines that have engraved pendant triangles on the lines. The vessel body has three sets of engraved spirals (Figure 59).

PIGMENT USE AND LOCATION ON VESSEL: none

TYPE AND VARIETY [IF KNOWN]: Poynor Engraved, var. Freeman 
SITE NAME OR SITE NUMBER: Pierce Freeman

VESSEL NO.: 41AN34-10; Burial D-1

NON-PLASTICS AND PASTE: grog and hematite; fine sandy paste

VESSEL FORM: Miniature globular bowl with four suspension holes on the rim (Figure 60)

RIM AND LIP FORM: Direct rim and rounded lip

CORE COLOR: A (fired and cooled in an oxidizing environment)

INTERIOR SURFACE COLOR: strong brown

EXTERIOR SURFACE COLOR: strong brown

WALL THICKNESS (RIM, BODY, AND BASE

IN MM): rim, $6.1 \mathrm{~mm}$

INTERIOR SURFACE TREATMENT: smoothed on the rim

EXTERIOR SURFACE TREATMENT: smoothed on the rim and body

HEIGHT (IN CM): 5.3

ORIFICE DIAMETER (IN CM): 6.1

DIAMETER AT BOTTOM OF RIM OR NECK (IN CM): 5.7

BASE DIAMETER (IN CM) AND SHAPE OF

BASE: 5.2; circular and flat

ESTIMATED VOLUME (IN LITERS): 0.13

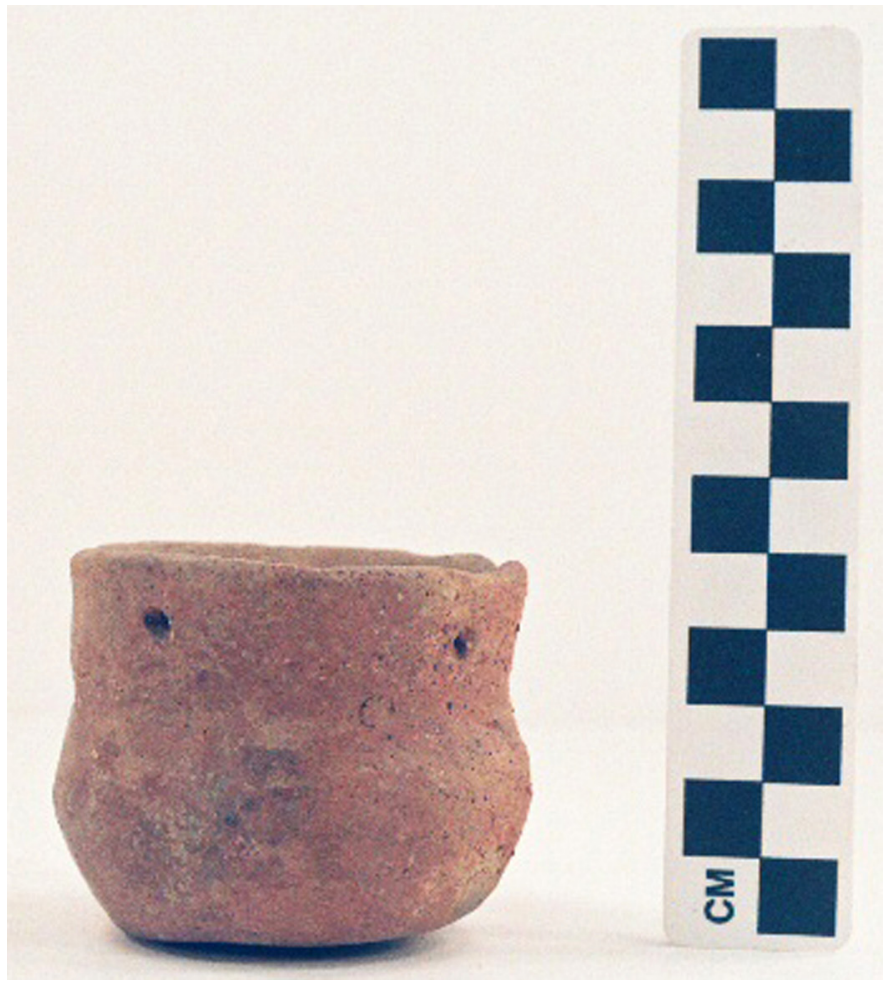

Figure 60. Plain miniature globular bowl from the Pierce Freeman site.

DECORATION (INCLUDING MOTIF AND ELEMENTS WHEN APPARENT): Plain (Figure 60)

PIGMENT USE AND LOCATION ON VESSEL: none

TYPE AND VARIETY [IF KNOWN]: Unidentified plain ware 
SITE NAME OR SITE NUMBER: Pierce Freeman

VESSEL NO.: 41AN34-11; Burial D-1

NON-PLASTICS AND PASTE: grog and hematite

VESSEL FORM: Globular Bowl

RIM AND LIP FORM: Direct rim and rounded lip

CORE COLOR: A (fired and cooled in an oxidizing environment)

INTERIOR SURFACE COLOR: brown

EXTERIOR SURFACE COLOR: brown; black film/smudging on the rim and body; fire clouds on the body

WALL THICKNESS (RIM, BODY, AND BASE

IN MM): rim, $4.3 \mathrm{~mm}$

INTERIOR SURFACE TREATMENT: burnished on the rim and smoothed on the body

EXTERIOR SURFACE TREATMENT:

smoothed on the rim and body

HEIGHT (IN CM): 7.6

ORIFICE DIAMETER (IN CM): 7.0

DIAMETER AT BOTTOM OF RIM OR NECK (IN CM): 6.6

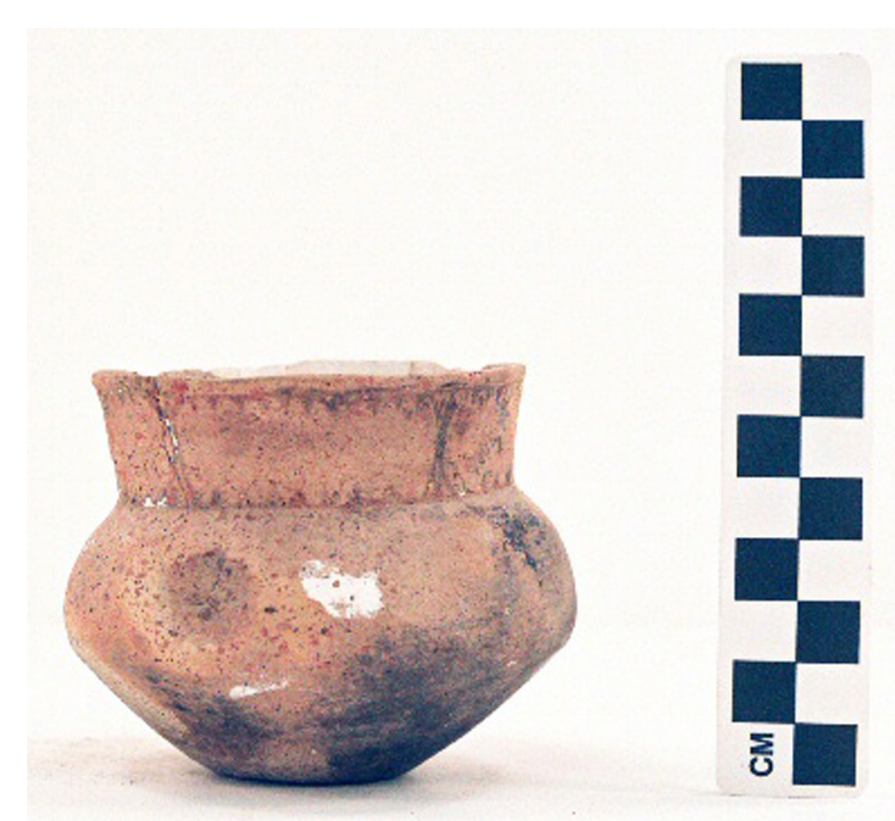

Figure 61. Poynor Engraved, var. Freeman globular bowl from the Pierce Freeman site.

BASE DIAMETER (IN CM) AND SHAPE OF BASE: 3.4; circular and flat ESTIMATED VOLUME (IN LITERS): 0.4

DECORATION (INCLUDING MOTIF AND ELEMENTS WHEN APPARENT): The rim panel is defined by single upper and lower horizontal engraved lines with either upwards- or downwards-pointing excised tick marks. The panel is divided into six oval sections by excised brackets (Figure 61).

PIGMENT USE AND LOCATION ON VESSEL: white pigment in engraved lines TYPE AND VARIETY [IF KNOWN]: Poynor Engraved, var. Freeman 
SITE NAME OR SITE NUMBER: Pierce Freeman

VESSEL NO.: 41AN34-16; Burial D-2

NON-PLASTICS AND PASTE: grog and hematite; fine sandy paste

VESSEL FORM: Globular Bowl

RIM AND LIP FORM: Direct rim and rounded lip

CORE COLOR: A (fired and cooled in an oxidizing environment)

INTERIOR SURFACE COLOR: reddish-yellow

EXTERIOR SURFACE COLOR: reddish-yellow

WALL THICKNESS (RIM, BODY, AND BASE

IN MM): rim, $5.8 \mathrm{~mm}$

INTERIOR SURFACE TREATMENT:

smoothed on the rim

EXTERIOR SURFACE TREATMENT:

smoothed on the rim

HEIGHT (IN CM): 16.5

ORIFICE DIAMETER (IN CM): 22.0

DIAMETER AT BOTTOM OF RIM OR NECK (IN CM): 22.2

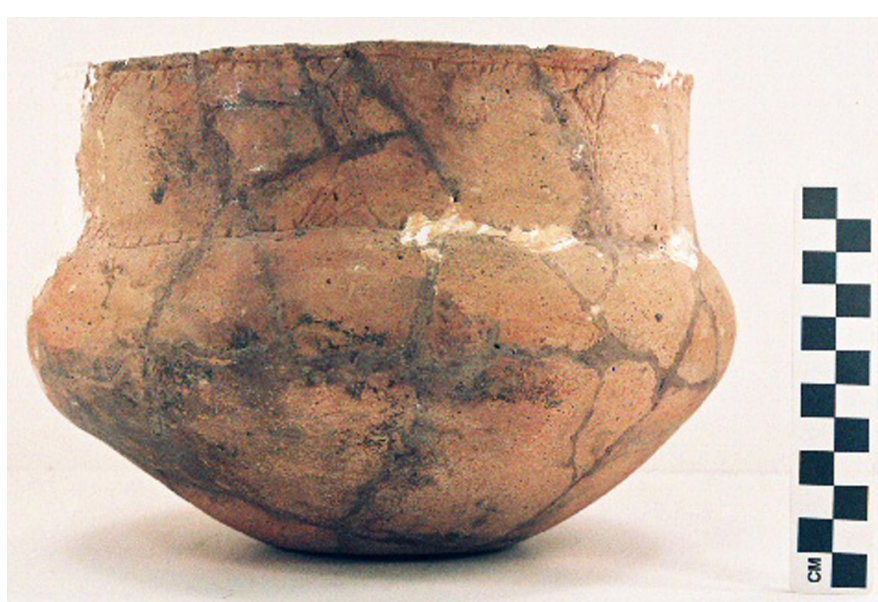

Figure 62. Poynor Engraved, var. Freeman globular bowl from the Pierce Freeman site.

BASE DIAMETER (IN CM) AND SHAPE OF BASE: 9.0; circular and flat

\section{ESTIMATED VOLUME (IN LITERS): 2.9}

DECORATION (INCLUDING MOTIF AND ELEMENTS WHEN APPARENT): The rim panel is defined by single upper and lower horizontal engraved lines with either upwards- or downwards-pointing excised tick marks. The panel is divided into eight sections by upper and lower opposed pendant triangles filled with cross-hatching (Figure 62).

PIGMENT USE AND LOCATION ON VESSEL: none

TYPE AND VARIETY [IF KNOWN]: Poynor Engraved, var. Freeman 
SITE NAME OR SITE NUMBER: Pierce Freeman

VESSEL NO.: 41AN34-17; Burial D-2

NON-PLASTICS AND PASTE: grog and hematite; fine sandy paste

VESSEL FORM: Effigy bowl with opposed effigy head and tail rider

RIM AND LIP FORM: Direct rim and flat lip

CORE COLOR: B (fired and cooled in a reducing environment)

INTERIOR SURFACE COLOR: very dark gray

EXTERIOR SURFACE COLOR: very dark gray

WALL THICKNESS (RIM, BODY, AND BASE

IN MM): $\operatorname{rim}, 8.0 \mathrm{~mm}$

INTERIOR SURFACE TREATMENT: none

EXTERIOR SURFACE TREATMENT:

smoothed on the rim and body

HEIGHT (IN CM): $10.5 ; 16.3 \mathrm{~cm}$ at top of the tail rider

ORIFICE DIAMETER (IN CM): 17.6

DIAMETER AT BOTTOM OF RIM OR NECK (IN CM): N/A

BASE DIAMETER (IN CM) AND SHAPE OF BASE: 12.3; circular and flat

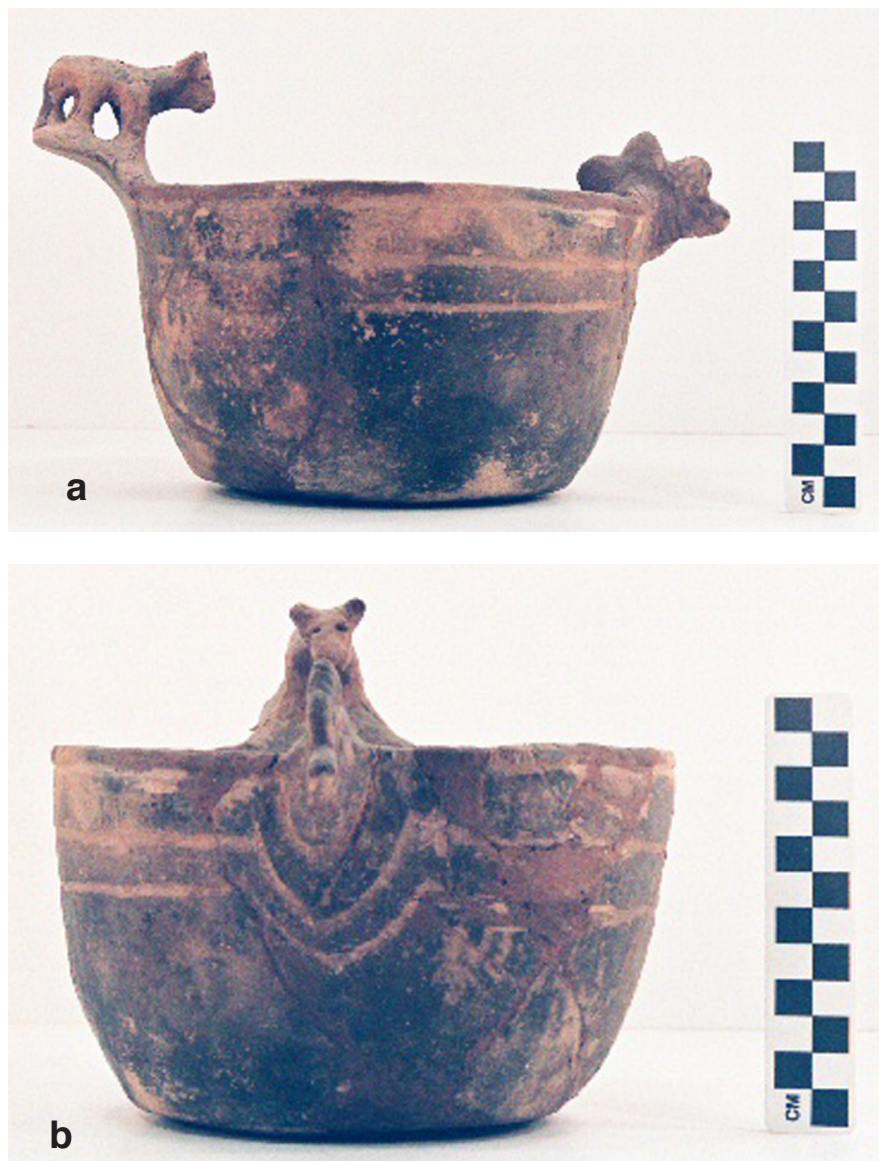

Figure 63. Hood Engraved, var. Allen effigy bowl: a, side view; $b$, view looking towards the quadruped.

ESTIMATED VOLUME (IN LITERS): 0.74

DECORATION (INCLUDING MOTIF AND ELEMENTS WHEN APPARENT): The rim of the bowl has three horizontal engraved lines (Figure 63a-b). The horizontal engraved lines dip under the opposed attachments. The effigy head appears to be a bird facing outwards, while the tail rider is looking inward towards the effigy head (Figure 63b). The tail rider is a quadruped, possibly a bear or a dog, with a long tail, and a head with two eyes, mouth, and erect ears.

PIGMENT USE AND LOCATION ON VESSEL: none

TYPE AND VARIETY [IF KNOWN]: Hood Engraved, var. Allen 
SITE NAME OR SITE NUMBER: Pierce Freeman

VESSEL NO.: 41AN34-22; Burial D-3

NON-PLASTICS AND PASTE: grog and hematite

VESSEL FORM: Carinated Bowl

RIM AND LIP FORM: Direct rim and rounded lip

CORE COLOR: A (fired and cooled in an oxidizing environment)

INTERIOR SURFACE COLOR: pale brown

EXTERIOR SURFACE COLOR: pale brown; fire clouds on the rim and body

WALL THICKNESS (RIM, BODY, AND

BASE IN MM): rim, $6.9 \mathrm{~mm}$

INTERIOR SURFACE TREATMENT:

smoothed on the rim

EXTERIOR SURFACE TREATMENT: none

HEIGHT (IN CM): 11.0

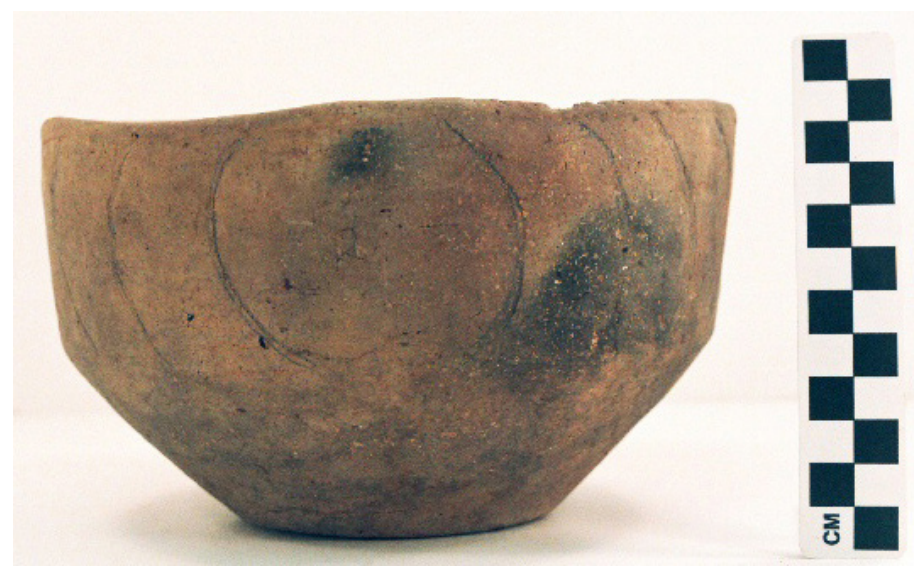

Figure 64. Poynor Engraved, var. Cook carinated bowl from the Pierce Freeman site.

ORIFICE DIAMETER (IN CM): 17.9

DIAMETER AT BOTTOM OF RIM OR NECK (IN CM): 17.9

BASE DIAMETER (IN CM) AND SHAPE OF BASE: 7.6; circular and flat

ESTIMATED VOLUME (IN LITERS): 1.2

DECORATION (INCLUDING MOTIF AND ELEMENTS WHEN APPARENT): the rim panel is defined by single upper and lower horizontal engraved lines. On the panel itself are a series of three sets of opposed curvilinear engraved lines (Figure 64). These sets are divided by sets of two closely-spaced curvilinear arcing engraved lines.

PIGMENT USE AND LOCATION ON VESSEL: none

TYPE AND VARIETY [IF KNOWN]: Poynor Engraved, var. Cook 
SITE NAME OR SITE NUMBER: Pierce Freeman

VESSEL NO.: 41AN34-23; Burial D-3

NON-PLASTICS AND PASTE: grog and hematite

VESSEL FORM: Globular Bowl

RIM AND LIP FORM: Direct rim and rounded lip

CORE COLOR: A (fired and cooled in an oxidizing environment)

INTERIOR SURFACE COLOR: light yellowishbrown

EXTERIOR SURFACE COLOR: light yellowish-brown

WALL THICKNESS (RIM, BODY, AND BASE IN MM): $\operatorname{rim}, 3.8 \mathrm{~mm}$

INTERIOR SURFACE TREATMENT: smoothed on the rim

EXTERIOR SURFACE TREATMENT:

smoothed on the rim and body

HEIGHT (IN CM): 9.7

ORIFICE DIAMETER (IN CM): 11.5

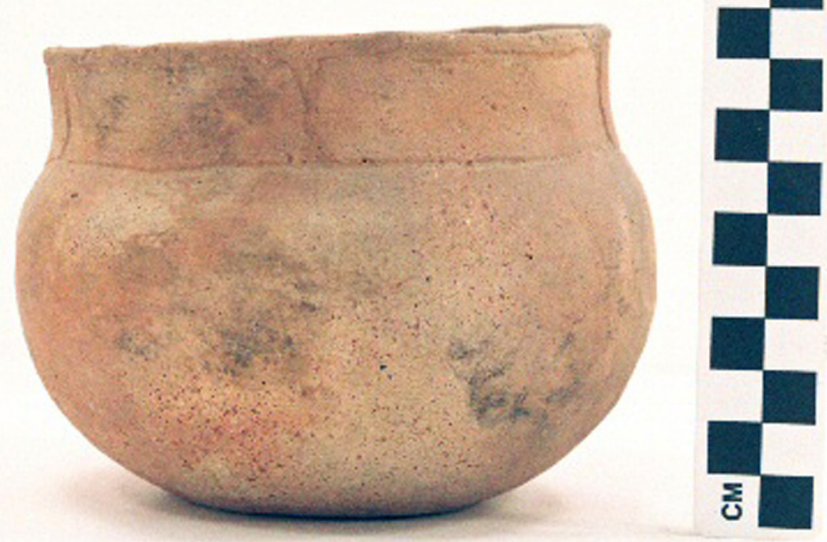

Figure 65. Poynor Engraved, var. Hood globular bowl from the Pierce Freeman site.

DIAMETER AT BOTTOM OF RIM OR NECK (IN CM): 11.2

BASE DIAMETER (IN CM) AND SHAPE OF BASE: 5.9; circular and flat

ESTIMATED VOLUME (IN LITERS): 0.9

DECORATION (INCLUDING MOTIF AND ELEMENTS WHEN APPARENT): the rim panel is defined by single upper and lower horizontal engraved lines. The panel is divided into five oval sections by excised brackets (Figure 65).

PIGMENT USE AND LOCATION ON VESSEL: none

TYPE AND VARIETY [IF KNOWN]: Poynor Engraved, var. Hood 
SITE NAME OR SITE NUMBER: Pierce Freeman

VESSEL NO.: 41AN34-24; Burial D-3

NON-PLASTICS AND PASTE: grog and hematite

VESSEL FORM: Globular Bowl

RIM AND LIP FORM: Direct rim and rounded lip

CORE COLOR: A (fired and cooled in an

oxidizing environment)

INTERIOR SURFACE COLOR: yellowish-red; fire clouds on the base

EXTERIOR SURFACE COLOR: yellowish-red; fire clouds on the base

WALL THICKNESS (RIM, BODY, AND BASE IN MM): rim, $5.5 \mathrm{~mm}$

INTERIOR SURFACE TREATMENT: smoothed on the rim and body

EXTERIOR SURFACE TREATMENT: smoothed on the rim and body

HEIGHT (IN CM): 7.0

ORIFICE DIAMETER (IN CM): 9.5

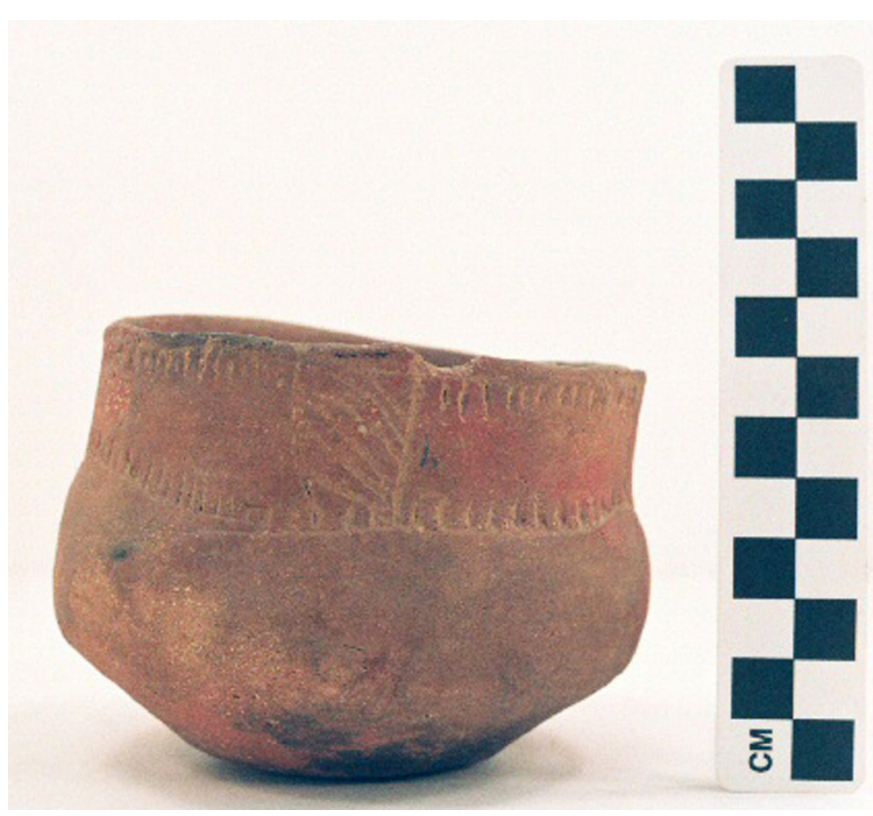

Figure 66. Poynor Engraved, var. Freeman globular bowl from the Pierce Freeman site.

DIAMETER AT BOTTOM OF RIM OR NECK (IN CM): 9.6

BASE DIAMETER (IN CM) AND SHAPE OF BASE: 5.2; circular and flat

ESTIMATED VOLUME (IN LITERS): 0.5

DECORATION (INCLUDING MOTIF AND ELEMENTS WHEN APPARENT): the rim panel is defined by single upper and lower horizontal engraved lines with linear tick marks. The panel is divided into four rectangular sections by four hatched columns (Figure 66).

PIGMENT USE AND LOCATION ON VESSEL: none

TYPE AND VARIETY [IF KNOWN]: Poynor Engraved, var. Freeman 
SITE NAME OR SITE NUMBER: Pierce Freeman

VESSEL NO.: 41AN34-27; Burial D-4

NON-PLASTICS AND PASTE: grog

VESSEL FORM: Jar with two opposed lug handles

RIM AND LIP FORM: Direct rim and rounded lip

CORE COLOR: A (fired and cooled in an oxidizing environment)

INTERIOR SURFACE COLOR: very pale brown with pink patches; fire clouds on the rim

EXTERIOR SURFACE COLOR: very pale brown with pink patches; fire clouds on the rim and body along with organic residue

WALL THICKNESS (RIM, BODY, AND BASE IN MM): rim, $4.8 \mathrm{~mm}$

INTERIOR SURFACE TREATMENT: none

EXTERIOR SURFACE TREATMENT: none

HEIGHT (IN CM): 10.0

ORIFICE DIAMETER (IN CM): 9.5

DIAMETER AT BOTTOM OF RIM OR NECK (IN CM): 9.5

BASE DIAMETER (IN CM) AND SHAPE OF BASE: 4.5 ; circular and flat

ESTIMATED VOLUME (IN LITERS): 0.6

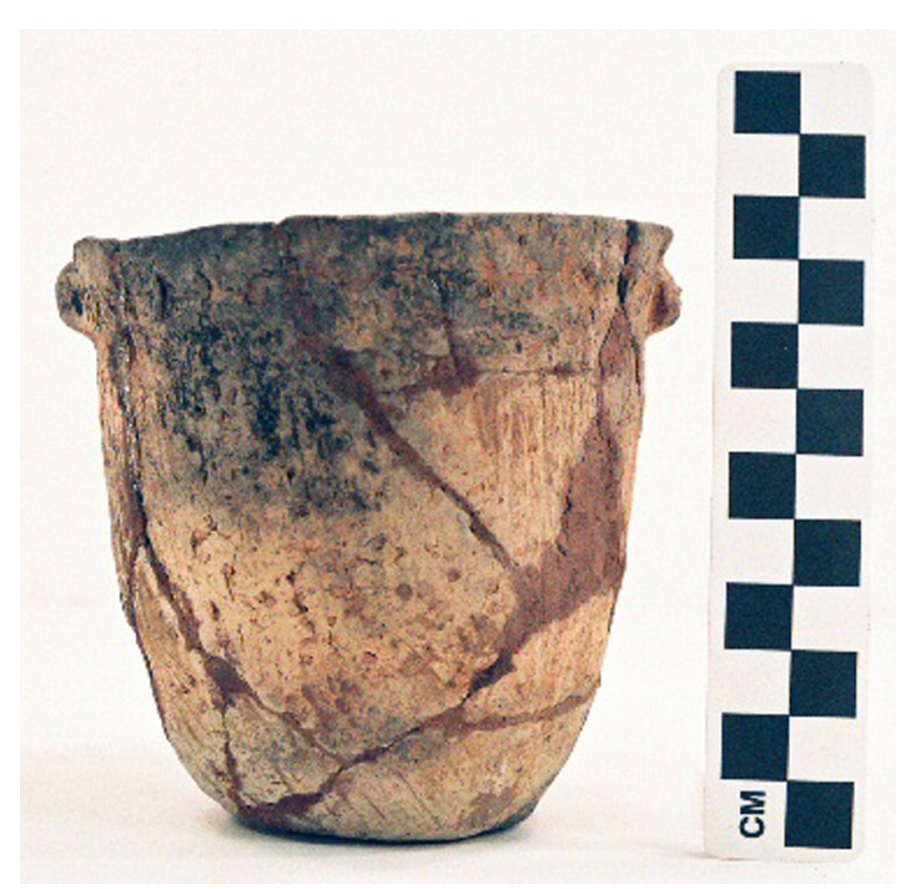

Figure 67. Bullard Brushed jar from the Pierce Freeman site.

DECORATION (INCLUDING MOTIF AND ELEMENTS WHEN APPARENT): The rim and body of the vessel have vertical brushing marks. There is also a single row of tool punctates under the vessel lip (Figure $67)$.

PIGMENT USE AND LOCATION ON VESSEL: none

TYPE AND VARIETY [IF KNOWN]: Bullard Brushed 
SITE NAME OR SITE NUMBER: Pierce Freeman

VESSEL NO.: 41AN34-28; Burial D-4

NON-PLASTICS AND PASTE: grog and hematite

VESSEL FORM: Globular Bowl

RIM AND LIP FORM: Direct rim and rounded lip

CORE COLOR: A (fired and cooled in an oxidizing environment)

INTERIOR SURFACE COLOR: reddishyellow

EXTERIOR SURFACE COLOR: light brown

WALL THICKNESS (RIM, BODY, AND

BASE IN MM): rim, $4.9 \mathrm{~mm}$

INTERIOR SURFACE TREATMENT:

smoothed on the rim and body

EXTERIOR SURFACE TREATMENT:

smoothed on the rim

HEIGHT (IN CM): 6.8

ORIFICE DIAMETER (IN CM): 8.1

DIAMETER AT BOTTOM OF RIM OR

NECK (IN CM): 7.4

BASE DIAMETER (IN CM) AND SHAPE

OF BASE: 5.5; circular and flat

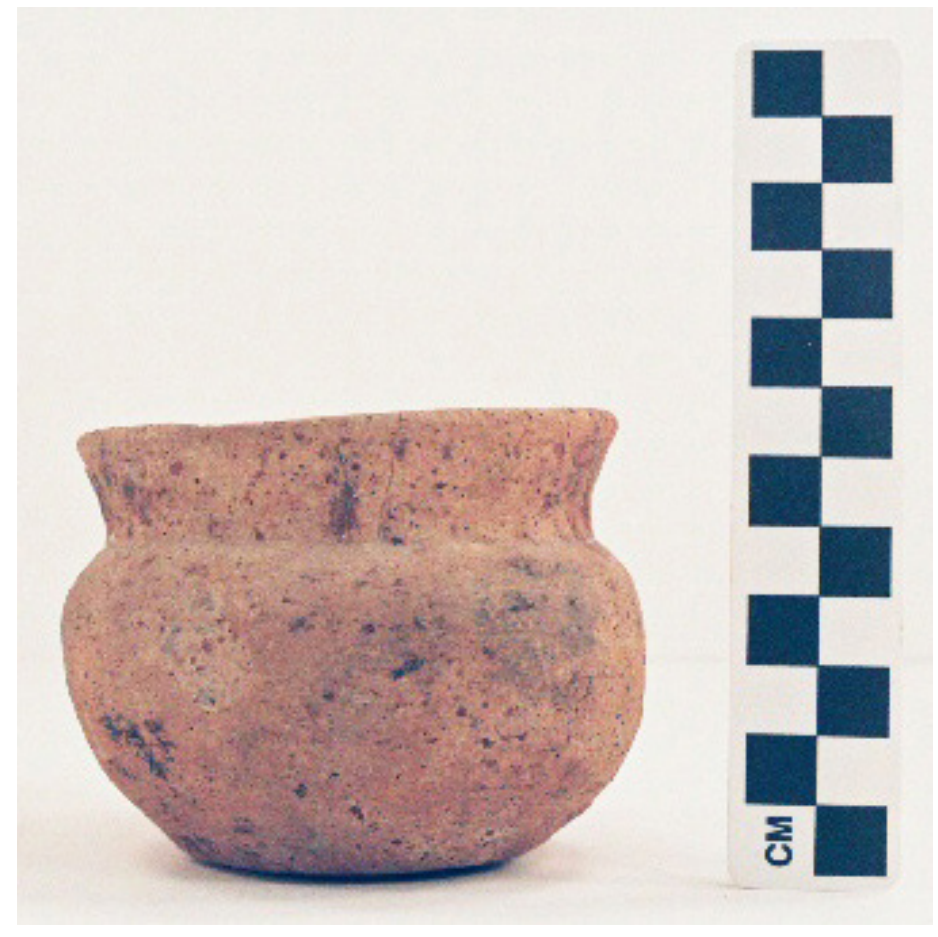

Figure 68. Poynor Engraved, var. Freeman globular bowl from the Pierce Freeman site.

ESTIMATED VOLUME (IN LITERS): 0.4

DECORATION (INCLUDING MOTIF AND ELEMENTS WHEN APPARENT): The rim panel is defined by faint single upper and lower horizontal engraved lines with triangular tick marks that are either upwardsor downwards-pointing. The panel is divided into five rectangular sections by excised brackets (Figure 68).

PIGMENT USE AND LOCATION ON VESSEL: white pigment in engraved lines

TYPE AND VARIETY [IF KNOWN]: Poynor Engraved, var. Freeman 
SITE NAME OR SITE NUMBER: Pierce Freeman

VESSEL NO.: 41AN34-29; Burial D-4

NON-PLASTICS AND PASTE: grog and hematite

VESSEL FORM: Carinated Bowl

RIM AND LIP FORM: Direct rim and rounded lip

CORE COLOR: F (fired in a reducing environment and cooled in the open air)

INTERIOR SURFACE COLOR: light brown

EXTERIOR SURFACE COLOR: light brown

WALL THICKNESS (RIM, BODY, AND BASE IN MM): rim, $7.3 \mathrm{~mm}$

INTERIOR SURFACE TREATMENT:

smoothed on the rim and body

EXTERIOR SURFACE TREATMENT:

burnished on the rim

HEIGHT (IN CM): 14.5

ORIFICE DIAMETER (IN CM): 25.5

DIAMETER AT BOTTOM OF RIM OR

NECK (IN CM): 23.0

BASE DIAMETER (IN CM) AND SHAPE

OF BASE: 9.0; circular and flat

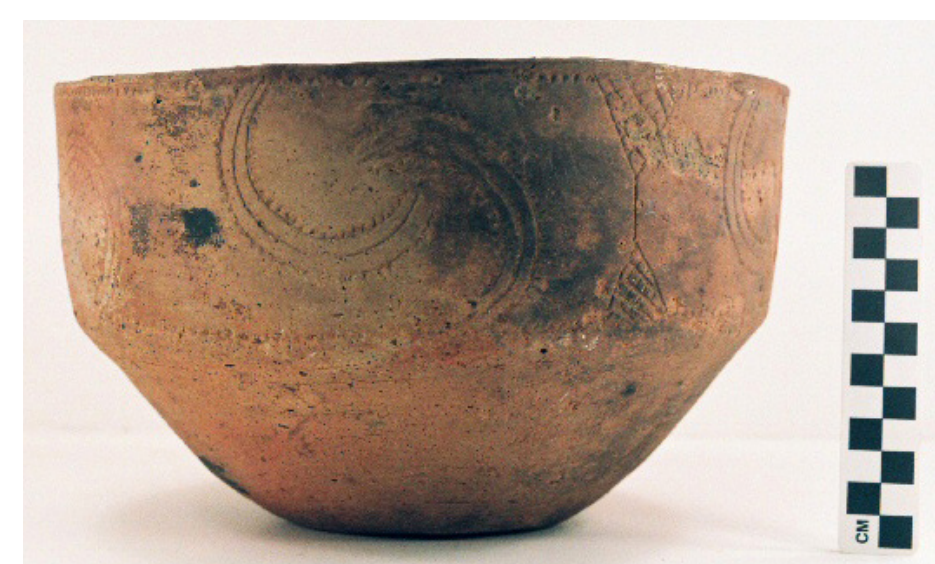

Figure 69. Patton Engraved, var. Patton carinated bowl from the Pierce Freeman site.

\section{ESTIMATED VOLUME (IN LITERS): 3.3}

DECORATION (INCLUDING MOTIF AND ELEMENTS WHEN APPARENT): The rim panel is defined by single upper and lower horizontal engraved lines with upward- or downward-pointing tick marks. The rim panel is divided into three sections by either large opposed engraved pendant triangles filled with crosshatched lines, or a set of three closely-spaced curvilinear engraved lines (Figure 69). There are pairs of two hooked arm elements (with three curvilinear lines) in two of the panel sections, and one pair in the third panel section. The outer lines of each of the hooked arm elements have outward-facing tick marks (Figure 69). The vessel body has horizontal brushing marks.

PIGMENT USE AND LOCATION ON VESSEL: white pigment in engraved lines 
SITE NAME OR SITE NUMBER: Pierce Freeman

VESSEL NO.: 41AN34-30

NON-PLASTICS AND PASTE: grog and hematite

VESSEL FORM: Globular Bowl

RIM AND LIP FORM: Everted rim and rounded lip

CORE COLOR: A (fired and cooled in an oxidizing environment)

INTERIOR SURFACE COLOR: light brown; fire clouds on the base

EXTERIOR SURFACE COLOR: reddish-yellow; fire clouds on the base

WALL THICKNESS (RIM, BODY, AND BASE

IN MM): rim, $5.7 \mathrm{~mm}$

INTERIOR SURFACE TREATMENT: smoothed on the rim and body

EXTERIOR SURFACE TREATMENT:

smoothed on the rim, body, and base

HEIGHT (IN CM): 17.2

ORIFICE DIAMETER (IN CM): 24.0

DIAMETER AT BOTTOM OF RIM OR NECK (IN CM): 23.0

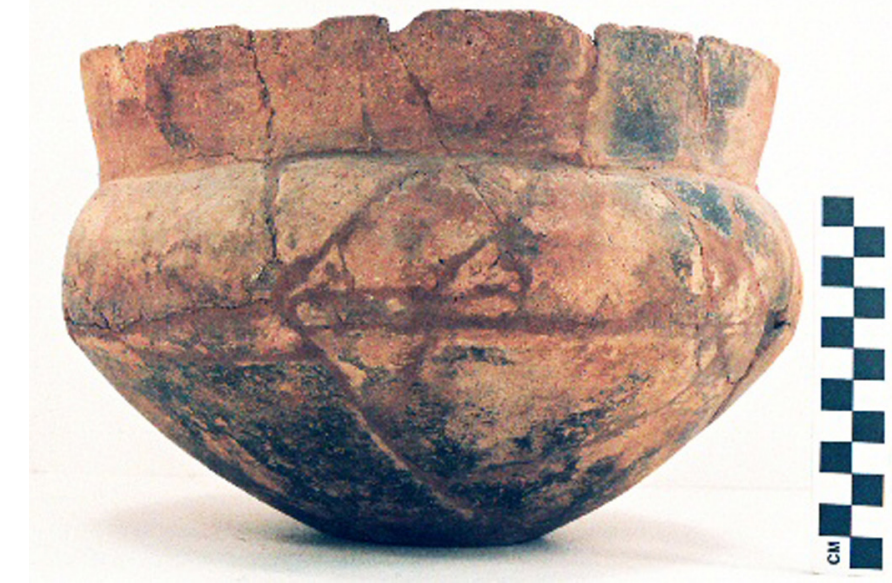

Figure 70. cf. Poynor Engraved, var. Freeman globular bowl from the Pierce Freeman site.

BASE DIAMETER (IN CM) AND SHAPE OF

BASE: 8.0; circular and flat

ESTIMATED VOLUME (IN LITERS): 3.3

DECORATION (INCLUDING MOTIF AND ELEMENTS WHEN APPARENT): The rim panel is defined by single upper and lower horizontal engraved lines, both with downward-pointing hatched pendant triangles; the bottom row of pendant triangles extends onto the vessel body (Figure 70). The rim panel is divided into at least five sections by excised brackets. There is a third horizontal engraved line midway on the body that has upwards-pointing hatched pendant triangles (Figure 70).

PIGMENT USE AND LOCATION ON VESSEL: white pigment in engraved lines

TYPE AND VARIETY [IF KNOWN]: cf. Poynor Engraved, var. Freeman 
SITE NAME OR SITE NUMBER: Pierce Freeman

VESSEL NO.: 41AN34-31; Burial D-4

NON-PLASTICS AND PASTE: grog and hematite

VESSEL FORM: Globular Bowl

RIM AND LIP FORM: Direct rim and rounded lip

CORE COLOR: A (fired and cooled in an oxidizing environment)

INTERIOR SURFACE COLOR: strong brown

EXTERIOR SURFACE COLOR: strong brown; black film/smudging on the rim and body

WALL THICKNESS (RIM, BODY, AND BASE IN MM): rim, $5.7 \mathrm{~mm}$; body, $5.7 \mathrm{~mm}$

INTERIOR SURFACE TREATMENT: smoothed on the rim

EXTERIOR SURFACE TREATMENT:

smoothed on the rim and body

HEIGHT (IN CM): 12.2

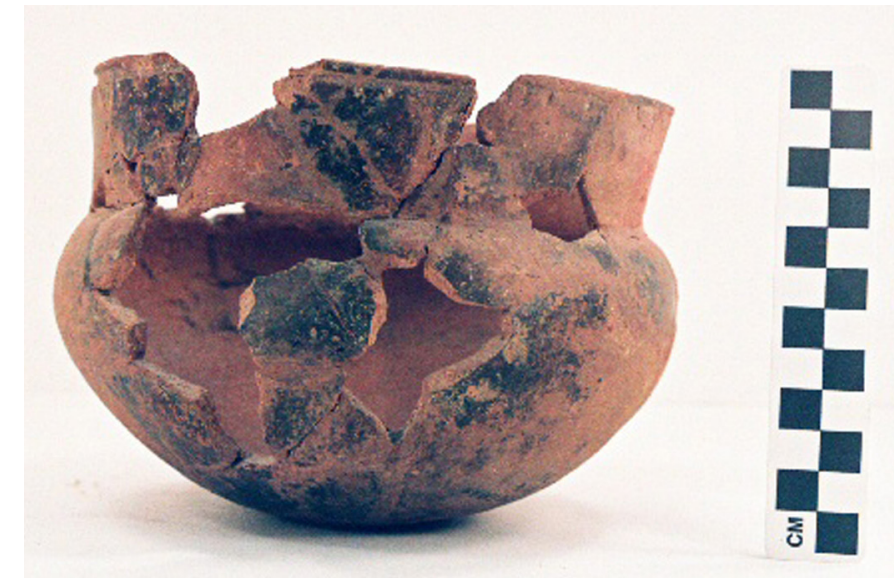

Figure 71. Poynor Engraved, var. Freeman globular bowl from the Pierce Freeman site.

ORIFICE DIAMETER (IN CM): 15.5

DIAMETER AT BOTTOM OF RIM OR NECK (IN CM): $16.3 \mathrm{~cm}$ at widest point on the body

BASE DIAMETER (IN CM) AND SHAPE OF BASE: 6.5; circular and flat

ESTIMATED VOLUME (IN LITERS): 1.5

DECORATION (INCLUDING MOTIF AND ELEMENTS WHEN APPARENT): The rim panel is defined by single upper and lower horizontal engraved lines. The upper engraved line has downward-pointing excised tick marks (Figure 71). The panel is divided into oval-shaped sections by excised brackets.

PIGMENT USE AND LOCATION ON VESSEL: white pigment in engraved lines

TYPE AND VARIETY [IF KNOWN]: Poynor Engraved, var. Freeman 


\section{E. W. Hackney Site (41CE6) Vessels}

The E. W. Hackney site is an ancestral Caddo habitation site and small cemetery on a tributary of Killough Creek in the upper Neches River basin. UT archeologists excavated two burials at the site in 1935 (Cole 1975:101-110; Marceaux 2011:424; Woolsey 1935a) and also identified a nearby midden area. In addition to the recovery of eight ceramic vessels, described below, a possible gunflint and a brass hawk bell were among the funerary objects in the burials.

SITE NAME OR SITE NUMBER: E. W. Hackney

VESSEL NO.: 41CE6-1; Burial Feature AN-1

NON-PLASTICS AND PASTE: grog

VESSEL FORM: Globular bowl

RIM AND LIP FORM: Direct rim and rounded lip

CORE COLOR: $\mathrm{F}$ (fired in a reducing

environment and cooled in the open air)

INTERIOR SURFACE COLOR: light yellowishbrown; fire clouds on the rim

EXTERIOR SURFACE COLOR: light yellowishbrown; fire clouds on the body and base

WALL THICKNESS (RIM, BODY, AND BASE IN MM): rim, $5.2 \mathrm{~mm}$

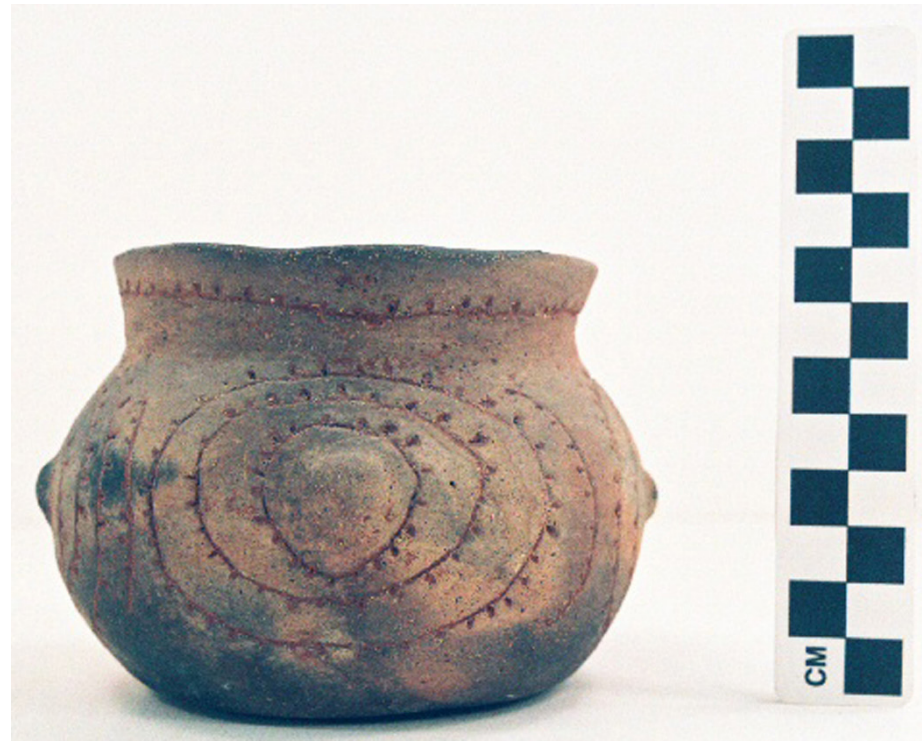

Figure 72. Patton Engraved, var. Fair globular bowl from the E. W. Hackney site.

INTERIOR SURFACE TREATMENT: smoothed on the rim

EXTERIOR SURFACE TREATMENT: none

HEIGHT (IN CM): 8.5

ORIFICE DIAMETER (IN CM): 9.0

DIAMETER AT BOTTOM OF RIM OR NECK (IN CM): 8.4

BASE DIAMETER (IN CM) AND SHAPE OF BASE: 8.0

ESTIMATED VOLUME (IN LITERS): 0.3

DECORATION (INCLUDING MOTIF AND ELEMENTS WHEN APPARENT): The rim has a single horizontal engraved line with upwards-pointing tick marks. The vessel body has four sets of engraved concentric circles with tick marks, and at the center of each set of concentric circles is an appliqued node (Figure 72).

PIGMENT USE AND LOCATION ON VESSEL: none

TYPE AND VARIETY [IF KNOWN]: Patton Engraved, var. Fair 
SITE NAME OR SITE NUMBER: E. W. Hackney

VESSEL NO.: 41CE6-3; Burial Feature AN-1

NON-PLASTICS AND PASTE: grog and hematite; fine sandy paste

VESSEL FORM: Carinated bowl

RIM AND LIP FORM: Inverted rim and a rounded lip

CORE COLOR: A (fired and cooled in an oxidizing environment)

INTERIOR SURFACE COLOR: very pale brown; fire clouds on the base

EXTERIOR SURFACE COLOR: very pale brown; fire clouds on the rim, body, and base

WALL THICKNESS (RIM, BODY, AND BASE

IN MM): rim, $7.0 \mathrm{~mm}$

INTERIOR SURFACE TREATMENT: smoothed on the rim and body

EXTERIOR SURFACE TREATMENT: smoothed on the rim

HEIGHT (IN CM): 19.5

ORIFICE DIAMETER (IN CM): 28.7

DIAMETER AT BOTTOM OF RIM OR NECK (IN CM): 29.1

BASE DIAMETER (IN CM) AND SHAPE OF

BASE: 9.8 , circular and flat

\section{ESTIMATED VOLUME (IN LITERS): 5.0}

DECORATION (INCLUDING MOTIF AND ELEMENTS WHEN APPARENT): The rim has a single horizontal engraved line under the lip with downward-pointing tick marks and a second line just above the carination with upward-pointing tick marks. The remainder of the rim has three repeating sets of vertically arcing engraving lines, each set comprised of four sets of arcing lines. The outer engraved line in each of the sets of four lines has outward-pointing tick marks. The vessel body has horizontal to overlapping brushing marks (Figure 73).

PIGMENT USE AND LOCATION ON VESSEL: none

TYPE AND VARIETY [IF KNOWN]: Patton Engraved, var. Patton 
SITE NAME OR SITE NUMBER: E. W. Hackney

VESSEL NO.: 41CE6-7; Burial AN-2

NON-PLASTICS AND PASTE: grog and hematite; fine sandy paste

VESSEL FORM: Effigy bowl with opposed effigy head and tail rider

RIM AND LIP FORM: Direct rim and rounded lip

CORE COLOR: F (fired in a reducing environment and cooled in the open air)

INTERIOR SURFACE COLOR: brown; fire clouds on the rim and body

EXTERIOR SURFACE COLOR: brown; fire clouds on the base

WALL THICKNESS (RIM, BODY, AND BASE

IN MM): rim, $7.5 \mathrm{~mm}$

INTERIOR SURFACE TREATMENT: smoothed on the upper part of the vessel

EXTERIOR SURFACE TREATMENT: smoothed on the upper part of the vessel

HEIGHT (IN CM): $12.8 ; 18.6 \mathrm{~cm}$ atop the tail rider's head

ORIFICE DIAMETER (IN CM): 17.5

DIAMETER AT BOTTOM OF RIM OR NECK (IN CM): N/A

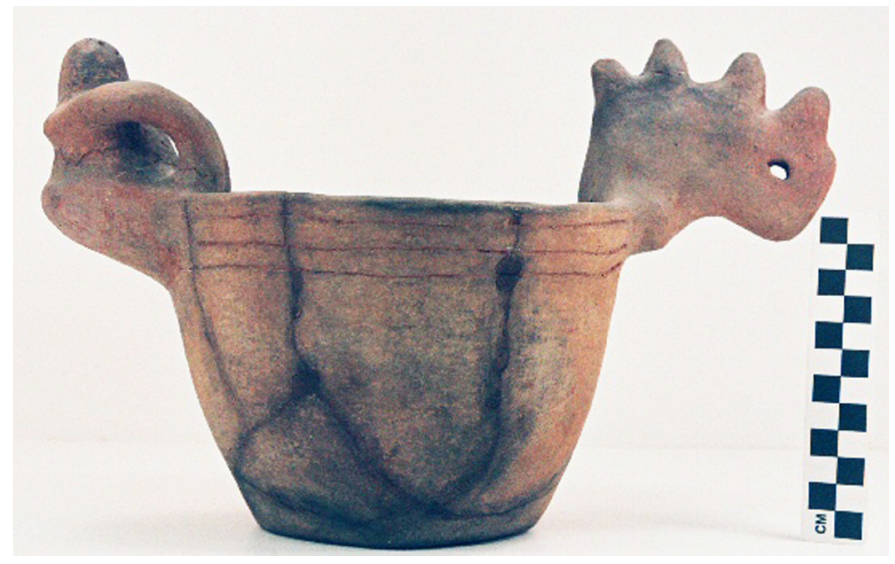

Figure 74. Hood Engraved, var. Allen effigy bowl from the E. W. Hackney site.

BASE DIAMETER (IN CM) AND SHAPE OF BASE: 10.0, circular and flat

ESTIMATED VOLUME (IN LITERS): 0.9

DECORATION (INCLUDING MOTIF AND ELEMENTS WHEN APPARENT): There are three discontinuous horizontal engraved lines on the vessel rim; the lines are discontinuous beneath the effigy head and the tail rider (Figure 74). The effigy head is that of a bird or duck with a crested head, and the tail rider is an anthropomorphic figure with a head, trunk, and arms/hands; the arms/hands are attached to the vessel rim.

PIGMENT USE AND LOCATION ON VESSEL: red pigment in engraved lines TYPE AND VARIETY [IF KNOWN]: Hood Engraved, var. Allen 
SITE NAME OR SITE NUMBER: E. W. Hackney

VESSEL NO.: 41CE6-8; Burial AN-2

NON-PLASTICS AND PASTE: grog

VESSEL FORM: Bottle with a short neck

RIM AND LIP FORM: Direct rim and a rounded $\operatorname{lip}$

CORE COLOR: A (fired and cooled in an oxidizing environment)

INTERIOR SURFACE COLOR: light yellowishbrown

EXTERIOR SURFACE COLOR: light yellowishbrown; fire clouds on the rim, body, and base

WALL THICKNESS (RIM, BODY, AND BASE IN MM): rim, $6.0 \mathrm{~mm}$

INTERIOR SURFACE TREATMENT: smoothed on the upper neck

EXTERIOR SURFACE TREATMENT: burnished on the neck and body

HEIGHT (IN CM): 17.0

ORIFICE DIAMETER (IN CM): 4.0

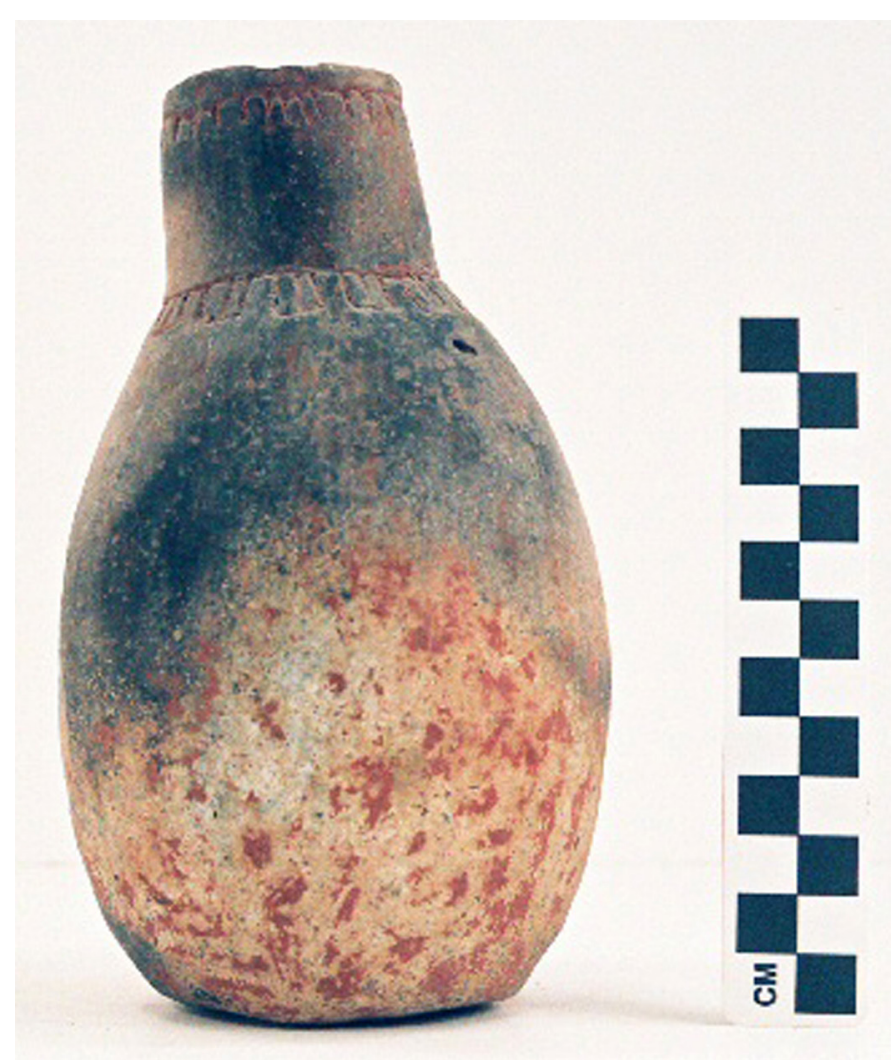

Figure 75. Engraved bottle from the E. W. Hackney site.

DIAMETER AT BOTTOM OF RIM OR NECK (IN CM): 5.0; $9.4 \mathrm{~cm}$ at its widest point on the body

BASE DIAMETER (IN CM) AND SHAPE OF BASE: 6.1, flat

ESTIMATED VOLUME (IN LITERS): 0.27

DECORATION (INCLUDING MOTIF AND ELEMENTS WHEN APPARENT): There is a single horizontal engraved line below the lip, and it has downward-pointing tick marks. The upper part of the vessel has a series of repeating small engraved rectangles, each with a single bisecting vertical engraved line (Figure 75).

PIGMENT USE AND LOCATION ON VESSEL: red pigment in engraved lines

TYPE AND VARIETY [IF KNOWN]: Unidentified fine ware bottle 
SITE NAME OR SITE NUMBER: E. W. Hackney

VESSEL NO.: 41CE6-9; Burial AN-2

NON-PLASTICS AND PASTE: grog

VESSEL FORM: Bottle with a short neck

RIM AND LIP FORM: Direct rim and rounded lip

CORE COLOR: A (fired and cooled in an oxidizing environment)

INTERIOR SURFACE COLOR: reddish-yellow

EXTERIOR SURFACE COLOR: reddish-yellow; fire clouds on the body and base

WALL THICKNESS (RIM, BODY, AND BASE IN MM): rim, $7.8 \mathrm{~mm}$

INTERIOR SURFACE TREATMENT: none

EXTERIOR SURFACE TREATMENT: none

HEIGHT (IN CM): 19.6

ORIFICE DIAMETER (IN CM): 5.0

DIAMETER AT BOTTOM OF RIM OR NECK (IN CM): $5.3 ; 10.5 \mathrm{~cm}$ at its widest point on the body

BASE DIAMETER (IN CM) AND SHAPE OF BASE: 6.2 ; circular and flat

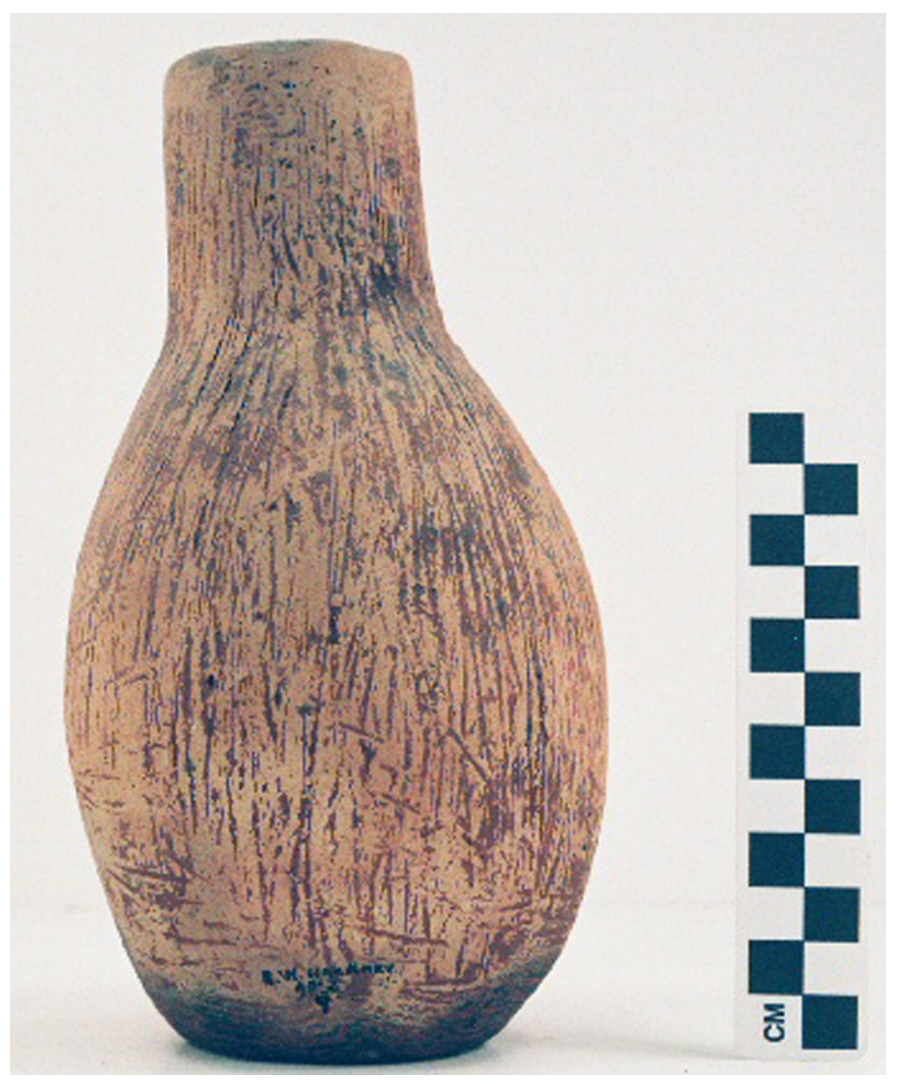

Figure 76. Brushed bottle from the E. W. Hackney site.

ESTIMATED VOLUME (IN LITERS): 0.5

DECORATION (INCLUDING MOTIF AND ELEMENTS WHEN APPARENT): The neck and much of the vessel body has vertical brushing marks. The lower body is covered with horizontal and overlapping brushed marks (Figure 76).

PIGMENT USE AND LOCATION ON VESSEL: none

TYPE AND VARIETY [IF KNOWN]: Unidentified brushed bottle 
SITE NAME OR SITE NUMBER: E. W. Hackney

VESSEL NO.: 41CE6-11; Burial AN-2

NON-PLASTICS AND PASTE: grog

VESSEL FORM: Globular Bowl

RIM AND LIP FORM: Direct rim and rounded lip

CORE COLOR: B (fired and cooled in a reducing environment)

INTERIOR SURFACE COLOR: grayish-brown

EXTERIOR SURFACE COLOR: grayish-brown

WALL THICKNESS (RIM, BODY, AND BASE

IN MM): rim, $5.0 \mathrm{~mm}$

INTERIOR SURFACE TREATMENT: smoothed on the rim and body

EXTERIOR SURFACE TREATMENT: smoothed on the rim

HEIGHT (IN CM): 12.0

ORIFICE DIAMETER (IN CM): 9.0

DIAMETER AT BOTTOM OF RIM OR NECK (IN CM): 9.3

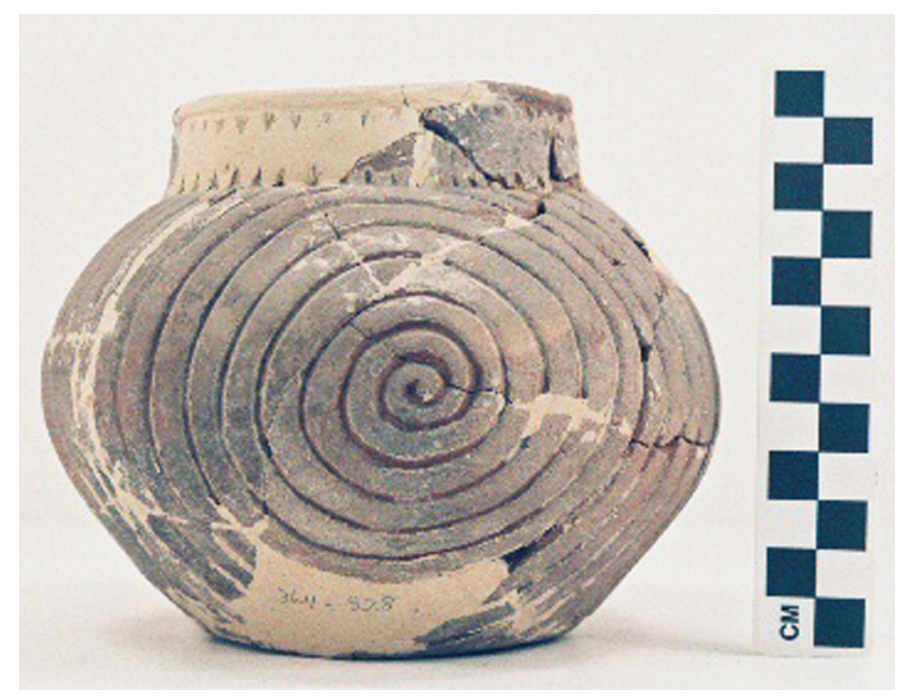

Figure 77. cf. Poynor Engraved, var. Freeman globular bowl from the $\mathrm{E}$. W. Hackney site.

BASE DIAMETER (IN CM) AND SHAPE OF BASE: 7.8; circular and flat

ESTIMATED VOLUME (IN LITERS): 0.43

DECORATION (INCLUDING MOTIF AND ELEMENTS WHEN APPARENT): The vessel rim has upper and lower rows of excised tick marks that either point downwards towards the vessel body or upwards towards the vessel lip. The vessel body has concentric hooked arm engraved spirals repeated twice around the vessel (Figure 77).

PIGMENT USE AND LOCATION ON VESSEL: none

TYPE AND VARIETY [IF KNOWN]: cf. Poynor Engraved, var. Freeman 
SITE NAME OR SITE NUMBER: E. W. Hackney

VESSEL NO.: 41CE6-12; Burial AN-2

NON-PLASTICS AND PASTE: bone

VESSEL FORM: Bottle with a spool neck

RIM AND LIP FORM: Everted rim and a rounded lip

CORE COLOR: B (fired and cooled in a reducing environment)

INTERIOR SURFACE COLOR: dark gray

EXTERIOR SURFACE COLOR: dark gray

WALL THICKNESS (RIM, BODY, AND BASE

IN MM): rim, $6.9 \mathrm{~mm}$

INTERIOR SURFACE TREATMENT: smoothed on upper neck

EXTERIOR SURFACE TREATMENT: smoothed on the neck and burnished on the vessel body

HEIGHT (IN CM): 24.0

ORIFICE DIAMETER (IN CM): 6.3

DIAMETER AT BOTTOM OF RIM OR NECK (IN CM): $6.7 ; 20.4 \mathrm{~cm}$ at its widest point on the body

BASE DIAMETER (IN CM) AND SHAPE OF BASE: 5.2; circular and flat

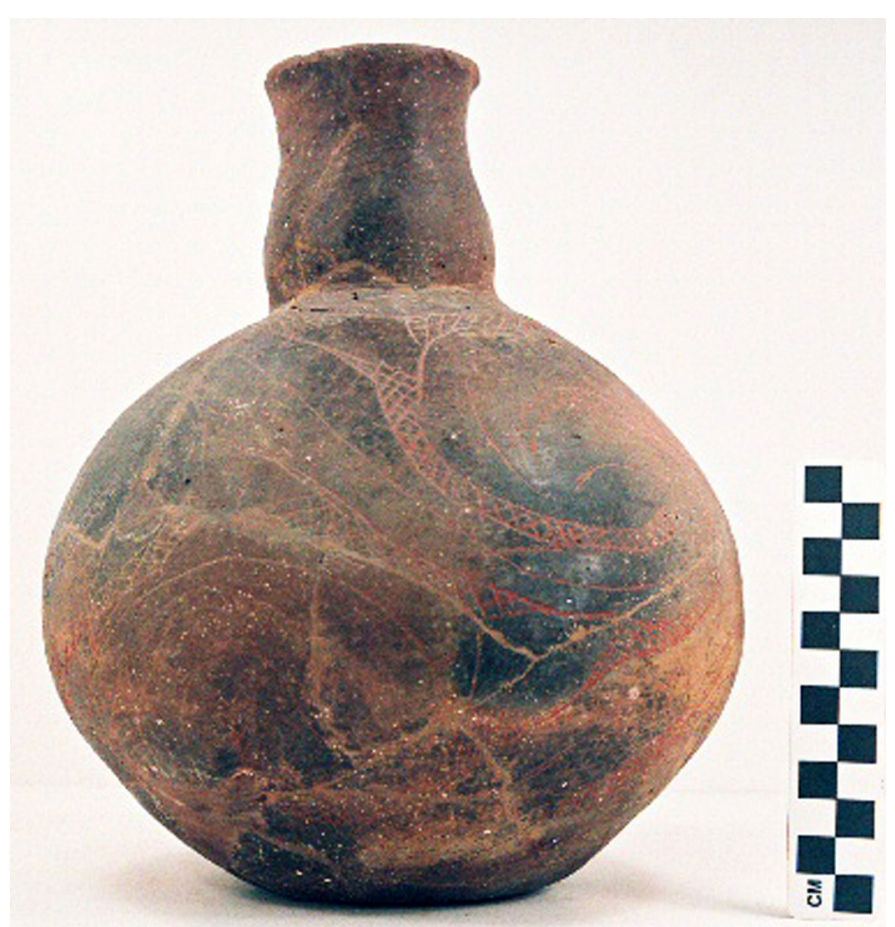

Figure 78. Hodges Engraved bottle from the E. W. Hackney site.

ESTIMATED VOLUME (IN LITERS): 0.5

DECORATION (INCLUDING MOTIF AND ELEMENTS WHEN APPARENT): There are four sets of engraved scrolls and hooked arms on the vessel, arranged in upper and lower tiers (Figure 78). Surrounding the scroll lines are cross-hatched zones that end in upper and lower hooked arms. Within each cross-hatched zone are negative circles and negative triangles.

PIGMENT USE AND LOCATION ON VESSEL: red pigment in the engraved lines

TYPE AND VARIETY [IF KNOWN]: Hodges Engraved 
SITE NAME OR SITE NUMBER: E. W. Hackney

VESSEL NO.: 41CE6-13, Burial AN-2

NON-PLASTICS AND PASTE: grog

VESSEL FORM: Jar or Deep Bowl

RIM AND LIP FORM: Everted rim and rounded lip

CORE COLOR: $\mathrm{G}$ (fired in a reducing

environment and cooled in the open air)

INTERIOR SURFACE COLOR: very dark gray

EXTERIOR SURFACE COLOR: light yellowishbrown; fire clouds on the rim, body, and base

WALL THICKNESS (RIM, BODY, AND BASE

IN MM): rim, $5.6 \mathrm{~mm}$

INTERIOR SURFACE TREATMENT: smoothed on the rim and body

EXTERIOR SURFACE TREATMENT: smoothed on the rim and body

HEIGHT (IN CM): 11.4

ORIFICE DIAMETER (IN CM): 8.8

DIAMETER AT BOTTOM OF RIM OR NECK (IN CM): 8.4

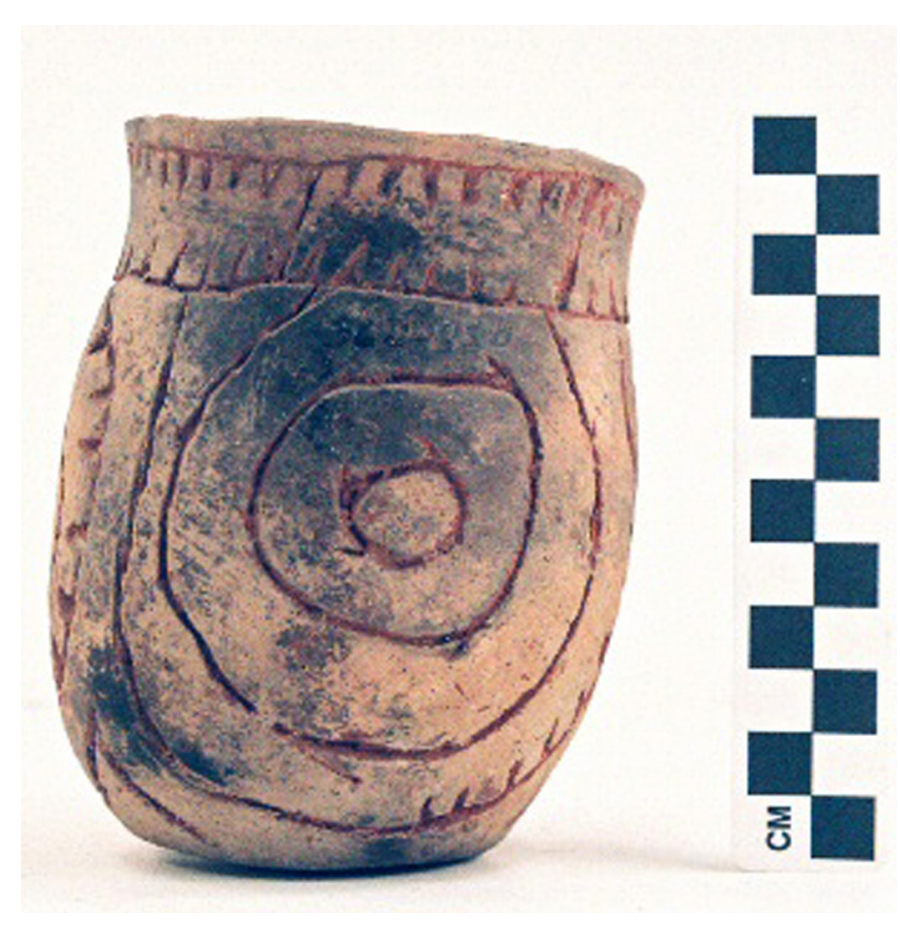

Figure 79. Patton Engraved, var. Freeman or var. Fair vessel from the $\mathrm{E}$. W. Hackney site.

BASE DIAMETER (IN CM) AND SHAPE OF BASE: 5.8; circular and flat

ESTIMATED VOLUME (IN LITERS): 0.8

DECORATION (INCLUDING MOTIF AND ELEMENTS WHEN APPARENT): The rim has upper and lower horizontal engraved lines with large excised tick marks that either point upwards or downwards (Figure 79). The horizontal lines are divided into four panels by vertical lines that end in upper and lower excised tick marks. The vessel body has three different concentric circle and semi-circle engraved elements. The first has tick marks on the inner circle; the second has tick marks along the top and sides of the outer semi-circle; and the third has tick marks on a portion of the outer semi-circle.

PIGMENT USE AND LOCATION ON VESSEL: white pigment in the engraved lines

TYPE AND VARIETY [IF KNOWN]: Patton Engraved, var. Freeman or var. Fair 


\section{Jim P. Allen Site (41CE12) Vessels}

The Jim P. Allen site is also situated about $0.8 \mathrm{~km}$ from Killough Creek. UT archeologists excavated 18 burials at the site in 1935 (Woolsey 1935b), after the landowner had found and excavated one burial (Perttula et al. 2011:Figure 11-7), and there were three nearby midden areas (Cole 1975:35 and Figure 2). One of the 19 burials had glass trade beads and a brass tinkler (Marceaux 2011:425-426).

SITE NAME OR SITE NUMBER: Jim P. Allen

VESSEL NO.: 41CE12-1; Burial AH-1

NON-PLASTICS AND PASTE: grog and hematite

VESSEL FORM: Jar

RIM AND LIP FORM: N/A

CORE COLOR: A (fired and cooled in an oxidizing environment)

INTERIOR SURFACE COLOR: light reddishbrown; pinkware

EXTERIOR SURFACE COLOR: yellowish-red

WALL THICKNESS (RIM, BODY, AND BASE IN MM): body, $6.6 \mathrm{~mm}$

INTERIOR SURFACE TREATMENT: smoothed on the body

EXTERIOR SURFACE TREATMENT: none

HEIGHT (IN CM): N/A

ORIFICE DIAMETER (IN CM): 12.2

DIAMETER AT BOTTOM OF RIM OR NECK (IN CM): N/A

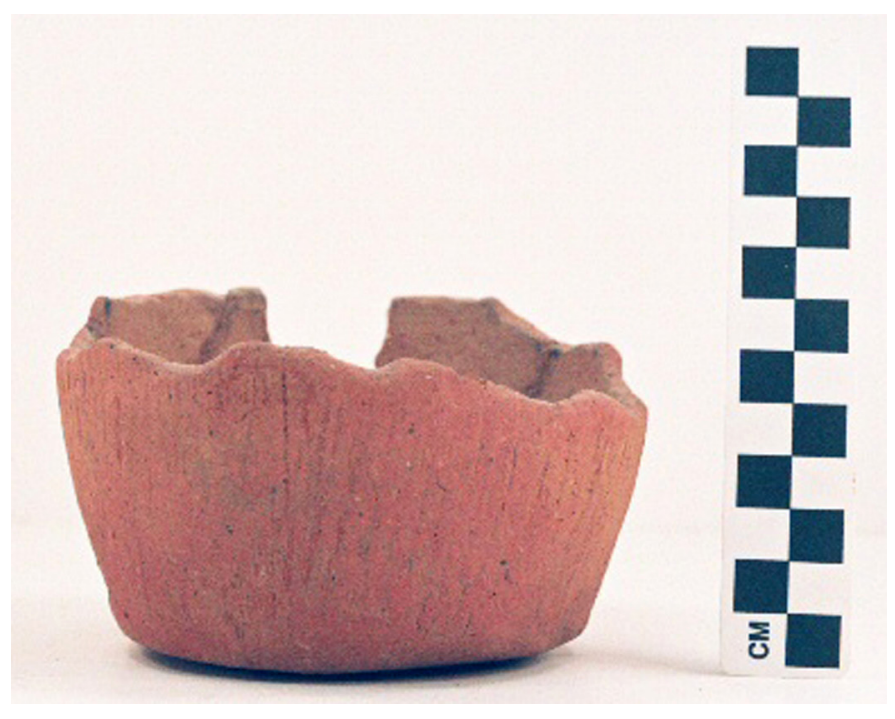

Figure 80. Bullard Brushed jar section from the Jim P. Allen site.

BASE DIAMETER (IN CM) AND SHAPE OF BASE: 9.1; circular and flat

ESTIMATED VOLUME (IN LITERS): N/A

DECORATION (INCLUDING MOTIF AND ELEMENTS WHEN APPARENT): Vertical brushing marks on the body that extend to the base (Figure 80).

PIGMENT USE AND LOCATION ON VESSEL: none

TYPE AND VARIETY [IF KNOWN]: Bullard Brushed 
SITE NAME OR SITE NUMBER: Jim P. Allen

VESSEL NO.: 41CE12-2; Burial AH-1

NON-PLASTICS AND PASTE: grog

VESSEL FORM: Cylindrical bottle with a short neck

RIM AND LIP FORM: Direct rim and flat lip

CORE COLOR: A (fired and cooled in an

oxidizing environment)

INTERIOR SURFACE COLOR: light yellowishbrown

EXTERIOR SURFACE COLOR: light yellowishbrown; fire clouds on the body

WALL THICKNESS (RIM, BODY, AND BASE IN MM): rim, $6.5 \mathrm{~mm}$

INTERIOR SURFACE TREATMENT: none

EXTERIOR SURFACE TREATMENT: smoothed on the body

HEIGHT (IN CM): 19.0

ORIFICE DIAMETER (IN CM): 4.0

DIAMETER AT BOTTOM OF RIM OR NECK (IN CM): $5.2 ; 10.5 \mathrm{~cm}$ at the widest point of the body

\section{BASE DIAMETER (IN CM) AND SHAPE OF}

BASE: 6.1 ; circular and flat

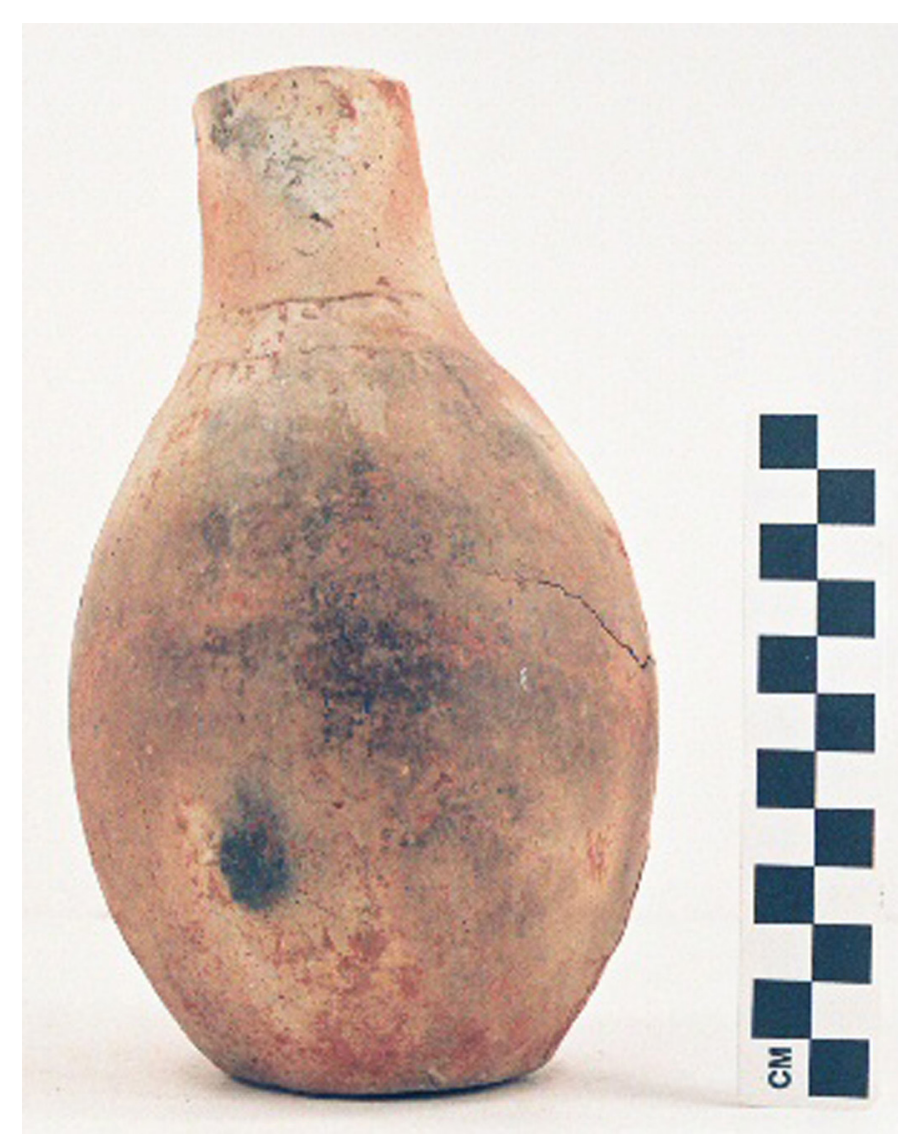

Figure 81. Hume Engraved, var. Allen bottle from the Jim P. Allen site.

ESTIMATED VOLUME (IN LITERS): 0.5

DECORATION (INCLUDING MOTIF AND ELEMENTS WHEN APPARENT): There are two horizontal engraved lines at the top of the vessel body. Each have linear tick marks on them (Figure 81).

PIGMENT USE AND LOCATION ON VESSEL: none

TYPE AND VARIETY [IF KNOWN]: Hume Engraved, var. Allen 
SITE NAME OR SITE NUMBER: Jim P. Allen

VESSEL NO.: 41CE12-3; Burial AH-1

NON-PLASTICS AND PASTE: grog and hematite; fine sandy paste

VESSEL FORM: Bottle with a short and bulbous neck

RIM AND LIP FORM: N/A

CORE COLOR: $\mathrm{G}$ (fired in a reducing environment and cooled in the open air)

INTERIOR SURFACE COLOR: dark gray

EXTERIOR SURFACE COLOR: reddish-yellow

WALL THICKNESS (RIM, BODY, AND BASE

IN MM): neck, $5.4 \mathrm{~mm}$

INTERIOR SURFACE TREATMENT: none

EXTERIOR SURFACE TREATMENT: none

HEIGHT (IN CM): 15.7+

ORIFICE DIAMETER (IN CM): 4.4

DIAMETER AT BOTTOM OF RIM OR NECK (IN CM): $5.4 ; 15.0 \mathrm{~cm}$ at its widest part on the body

BASE DIAMETER (IN CM) AND SHAPE OF

BASE: 4.7; circular and flat

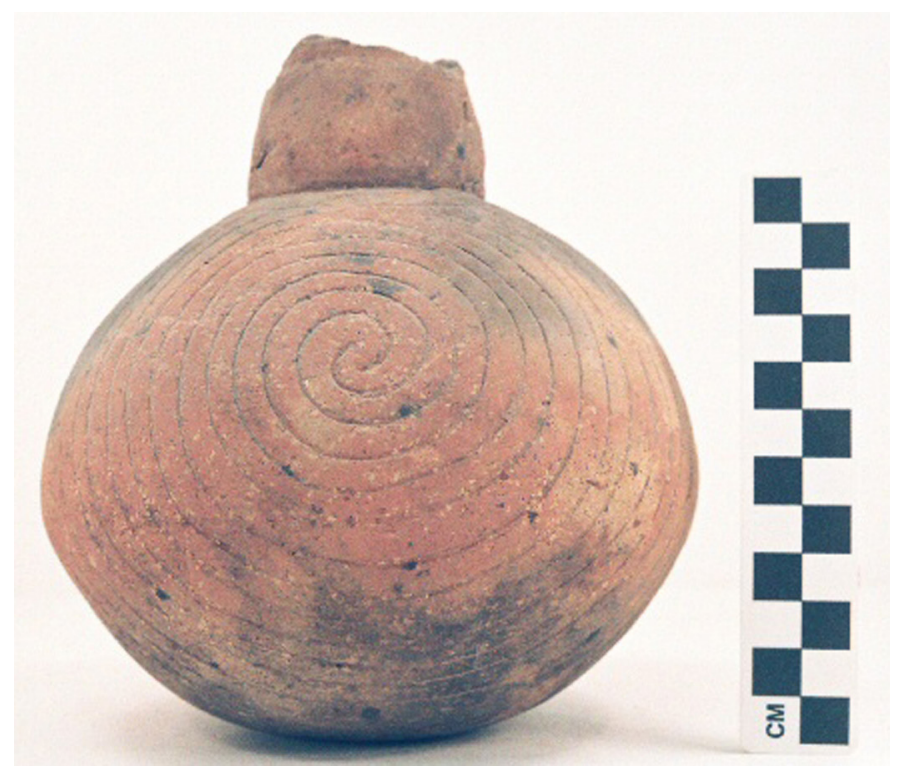

Figure 82. Keno Trailed bottle from the Jim P.Allen site.

ESTIMATED VOLUME (IN LITERS): 0.3

DECORATION (INCLUDING MOTIF AND ELEMENTS WHEN APPARENT): The vessel body has two horizontal trailed lines at the top of the body. The remainder of the body has either two sets of concentric trailed spirals or two sets of concentric trailed semi-circles (Figure 82).

PIGMENT USE AND LOCATION ON VESSEL: none

TYPE AND VARIETY [IF KNOWN]: Keno Trailed 
SITE NAME OR SITE NUMBER: Jim P. Allen

VESSEL NO.: 41CE12-4; Burial AH-1

NON-PLASTICS AND PASTE: grog and hematite; fine sandy paste

VESSEL FORM: Globular Bowl

RIM AND LIP FORM: Direct rim and rounded lip

CORE COLOR: A (fired and cooled in an oxidizing environment)

INTERIOR SURFACE COLOR: brownish-yellow

EXTERIOR SURFACE COLOR: brownish-yellow

WALL THICKNESS (RIM, BODY, AND BASE

IN MM): rim, $4.6 \mathrm{~mm}$

INTERIOR SURFACE TREATMENT: smoothed on the rim and body

EXTERIOR SURFACE TREATMENT: smoothed on the body

HEIGHT (IN CM): 11.3

ORIFICE DIAMETER (IN CM): 13.7

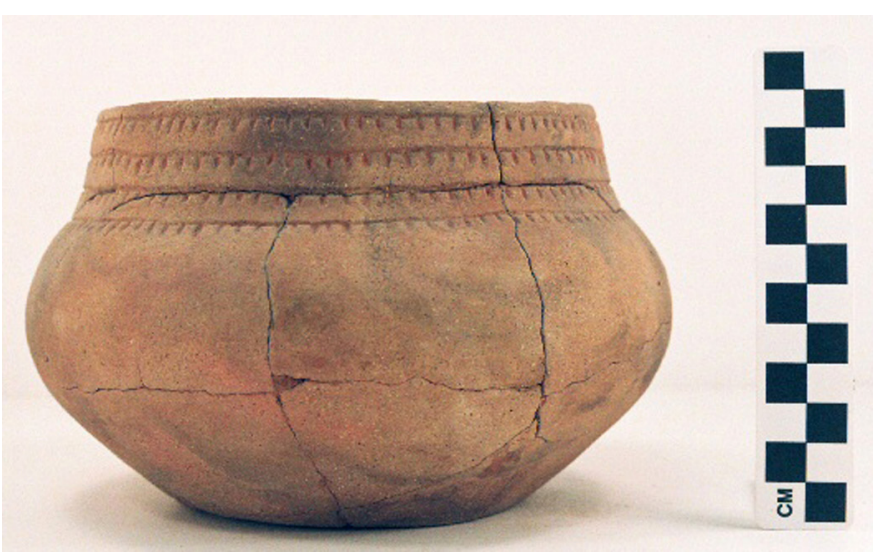

Figure 83. Patton Engraved, var. Allen globular bowl from the Jim P. Allen site.

DIAMETER AT BOTTOM OF RIM OR NECK (IN CM): 17.0

BASE DIAMETER (IN CM) AND SHAPE OF BASE: 9.5; circular and flat

ESTIMATED VOLUME (IN LITERS): 1.2

DECORATION (INCLUDING MOTIF AND ELEMENTS WHEN APPARENT): The rim has four horizontal engraved lines with downward-pointing excised tick marks (Figure 83).

PIGMENT USE AND LOCATION ON VESSEL: none

TYPE AND VARIETY [IF KNOWN]: Patton Engraved, var. Allen 
SITE NAME OR SITE NUMBER: Jim P. Allen

VESSEL NO.: 41CE12-6; Burial AH-1

NON-PLASTICS AND PASTE: grog and hematite; fine sandy paste

VESSEL FORM: Carinated Bowl

RIM AND LIP FORM: Inverted rim and rounded lip

CORE COLOR: A (fired and cooled in an oxidizing environment)

INTERIOR SURFACE COLOR: yellowish-brown; fire clouds on the body and base

EXTERIOR SURFACE COLOR: yellowish-

brown; fire clouds on the rim and body

WALL THICKNESS (RIM, BODY, AND BASE

IN MM): rim, $6.5 \mathrm{~mm}$

INTERIOR SURFACE TREATMENT: smoothed on the rim and body

EXTERIOR SURFACE TREATMENT: smoothed on the rim and body

HEIGHT (IN CM): 19.9

ORIFICE DIAMETER (IN CM): 20.0

DIAMETER AT BOTTOM OF RIM OR NECK (IN CM): 25.5

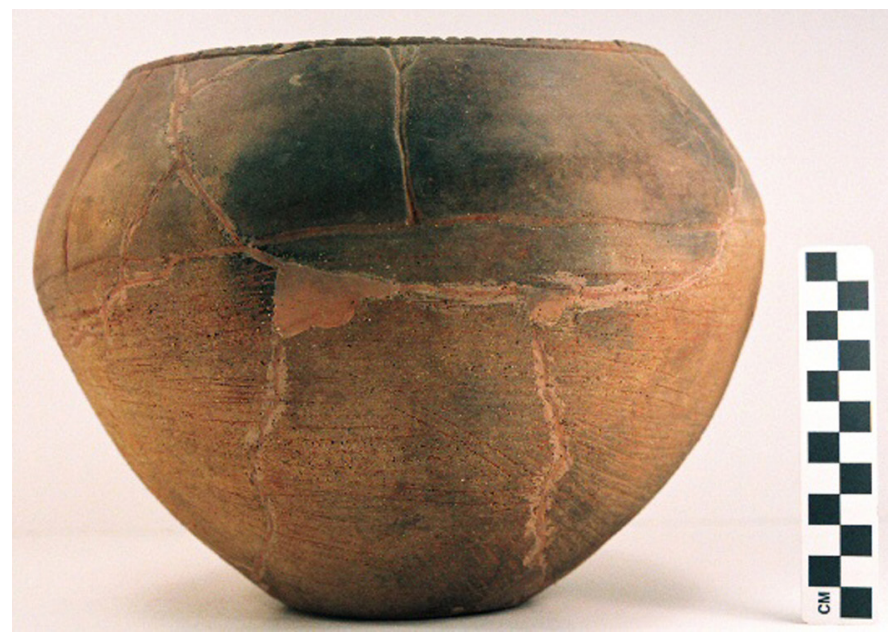

Figure 84. Poynor Engraved, var. Blackburn carinated bowl from the Jim P. Allen site.

BASE DIAMETER (IN CM) AND SHAPE OF BASE: 8.9; circular and flat

ESTIMATED VOLUME (IN LITERS): 3.6

DECORATION (INCLUDING MOTIF AND ELEMENTS WHEN APPARENT): The lip of the vessel is lip notched. The rim panel is defined by single upper and lower horizontal engraved lines, and the panel is divided into six sections by excised vertical lines that have a small triangular element at the top and bottom of the vertical lines (Figure 84).

PIGMENT USE AND LOCATION ON VESSEL: none

TYPE AND VARIETY [IF KNOWN]: Poynor Engraved, var. Blackburn 
SITE NAME OR SITE NUMBER: Jim P. Allen

VESSEL NO.: 41CE12-7; Burial AH-2

NON-PLASTICS AND PASTE: grog and hematite

VESSEL FORM: Globular Bowl

RIM AND LIP FORM: Direct rim and rounded lip

CORE COLOR: $\mathrm{G}$ (fired in a reducing environment and cooled in the open air)

INTERIOR SURFACE COLOR: dark gray

EXTERIOR SURFACE COLOR: reddish-yellow; fire clouds on the rim, body, and base

WALL THICKNESS (RIM, BODY, AND BASE

IN MM): rim, $5.0 \mathrm{~mm}$

INTERIOR SURFACE TREATMENT: smoothed on the rim

EXTERIOR SURFACE TREATMENT: smoothed on the rim

HEIGHT (IN CM): 9.3

ORIFICE DIAMETER (IN CM): 8.1

DIAMETER AT BOTTOM OF RIM OR NECK (IN CM): 9.0

BASE DIAMETER (IN CM) AND SHAPE OF

BASE: 4.9; circular and flat

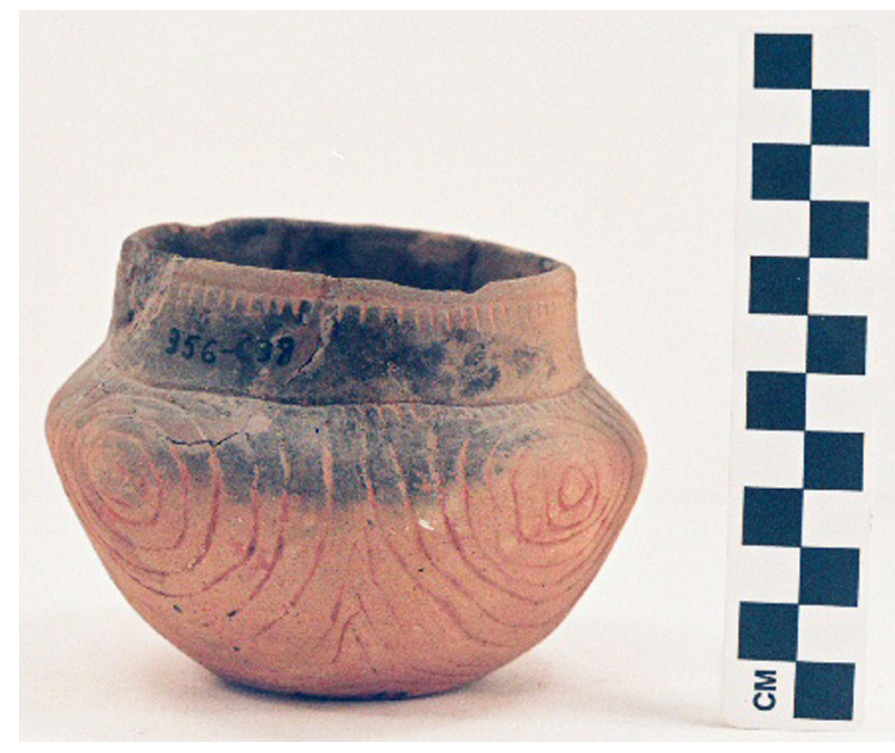

Figure 85. cf. Poynor Engraved, var. Freeman globular bowl from the Jim P. Allen site.

ESTIMATED VOLUME (IN LITERS): 0.6

DECORATION (INCLUDING MOTIF AND ELEMENTS WHEN APPARENT): The rim panel is defined by single upper and lower horizontal engraved lines with downward-pointing excised tick marks. The vessel body has four sets of concentric circle elements, and none of the concentric lines have tick marks (Figure $85)$.

PIGMENT USE AND LOCATION ON VESSEL: none

TYPE AND VARIETY [IF KNOWN]: cf. Poynor Engraved, var. Freeman 
SITE NAME OR SITE NUMBER: Jim P. Allen

VESSEL NO.: 41CE12-8; Burial AH-2

NON-PLASTICS AND PASTE: grog and hematite

VESSEL FORM: Effigy bowl with attached opposed effigy heads

RIM AND LIP FORM: Direct rim and rounded lip

CORE COLOR: A (fired and cooled in an oxidizing environment)

INTERIOR SURFACE COLOR: light brown; fire clouds on the body and base

EXTERIOR SURFACE COLOR: light brown; fire clouds on the base

WALL THICKNESS (RIM, BODY, AND BASE

IN MM): rim, $6.4 \mathrm{~mm}$

INTERIOR SURFACE TREATMENT: smoothed on the rim and body

EXTERIOR SURFACE TREATMENT: smoothed on the rim and body

HEIGHT (IN CM): 7.0

ORIFICE DIAMETER (IN CM): 13.0

DIAMETER AT BOTTOM OF RIM OR NECK (IN CM): N/A

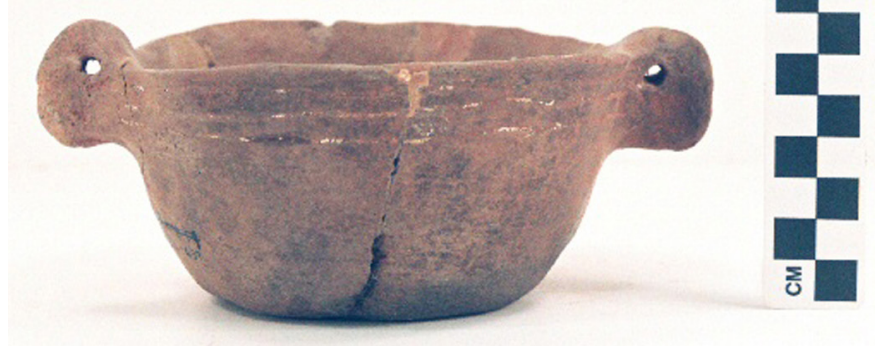

Figure 86. Hood Engraved, var. Hood effigy bowl from the Jim P. Allen site.

BASE DIAMETER (IN CM) AND SHAPE OF BASE: 8.0; circular and flat

ESTIMATED VOLUME (IN LITERS): 0.4

DECORATION (INCLUDING MOTIF AND ELEMENTS WHEN APPARENT): The vessel rim has three discontinuous horizontal engraved lines (Figure 86). The animal effigy heads have suspension holes for eyes.

PIGMENT USE AND LOCATION ON VESSEL: white pigment in engraved lines

TYPE AND VARIETY [IF KNOWN]: Hood Engraved, var. Hood 
SITE NAME OR SITE NUMBER: Jim P. Allen

VESSEL NO.: 41CE12-10; Burial AH-2

NON-PLASTICS AND PASTE: grog and hematite; fine sandy paste

VESSEL FORM: Cylindrical bottle [with a short neck]

RIM AND LIP FORM: N/A

CORE COLOR: A (fired and cooled in an oxidizing environment)

INTERIOR SURFACE COLOR: reddish-yellow

EXTERIOR SURFACE COLOR: reddish-yellow

WALL THICKNESS (RIM, BODY, AND BASE

IN MM): neck, $5.2 \mathrm{~mm}$

INTERIOR SURFACE TREATMENT: none

EXTERIOR SURFACE TREATMENT: smoothed on the body

HEIGHT (IN CM): $10.0 \mathrm{~cm}$ body height

ORIFICE DIAMETER (IN CM): 3.5

DIAMETER AT BOTTOM OF RIM OR NECK (IN CM): N/A

BASE DIAMETER (IN CM) AND SHAPE OF

BASE: 6.8; circular and flat

ESTIMATED VOLUME (IN LITERS): N/A

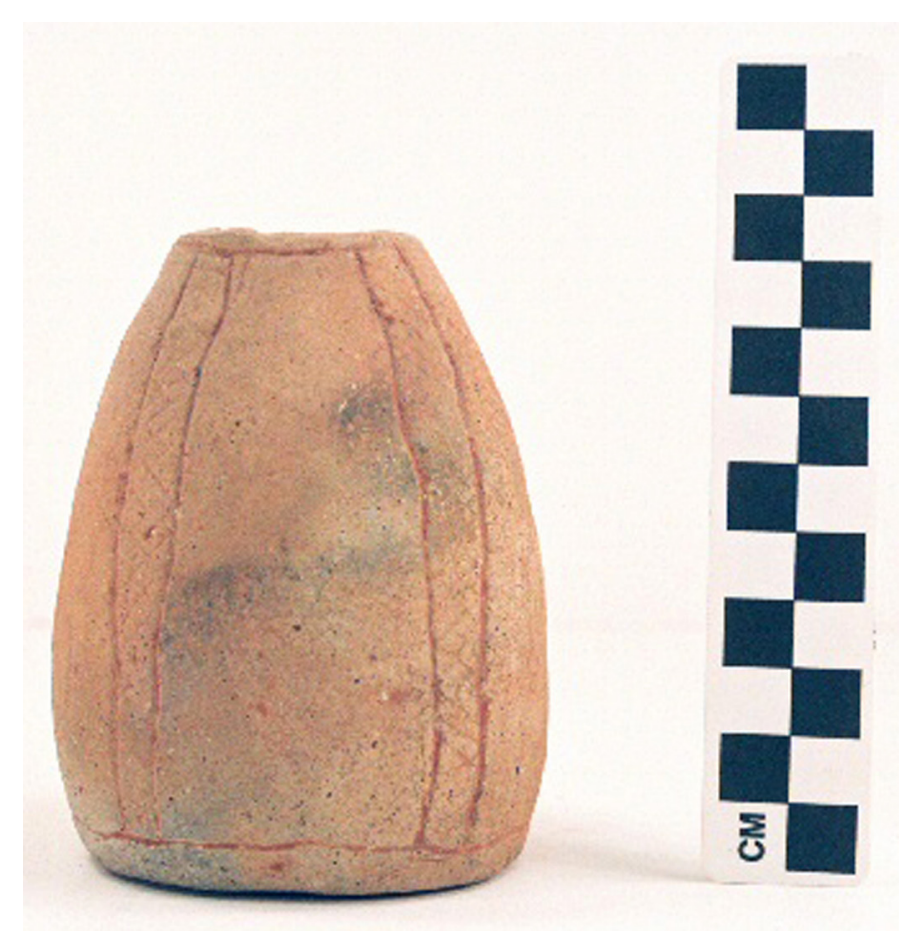

Figure 87. Hume Engraved, var. Hume bottle from the Jim P. Allen site.

DECORATION (INCLUDING MOTIF AND ELEMENTS WHEN APPARENT): The vessel body has four vertical bands or narrow zones around the vessel that are filled with cross-hatched engraved lines (Figure 87). The bands run between single upper and lower horizontal engraved lines.

PIGMENT USE AND LOCATION ON VESSEL: red pigment in engraved lines

TYPE AND VARIETY [IF KNOWN]: Hume Engraved, var. Hume 
SITE NAME OR SITE NUMBER: Jim P. Allen

VESSEL NO.: 41CE12-12; Burial AH-3

NON-PLASTICS AND PASTE: grog and hematite; fine sandy paste

VESSEL FORM: Bottle with a short neck

RIM AND LIP FORM: Direct rim and rounded lip

CORE COLOR: A (fired and cooled in an

oxidizing environment)

INTERIOR SURFACE COLOR: strong brown

EXTERIOR SURFACE COLOR: strong brown; fire clouds on the neck and body

WALL THICKNESS (RIM, BODY, AND BASE IN MM): neck, $6.3 \mathrm{~mm}$

INTERIOR SURFACE TREATMENT: none

EXTERIOR SURFACE TREATMENT: smoothed on the rim and body

HEIGHT (IN CM): 30.0

ORIFICE DIAMETER (IN CM): 4.2

DIAMETER AT BOTTOM OF RIM OR NECK (IN CM): $5.1 ; 14.7 \mathrm{~cm}$ at its widest point on the body

BASE DIAMETER (IN CM) AND SHAPE OF BASE: 8.4 ; circular and flat

ESTIMATED VOLUME (IN LITERS): 1.1

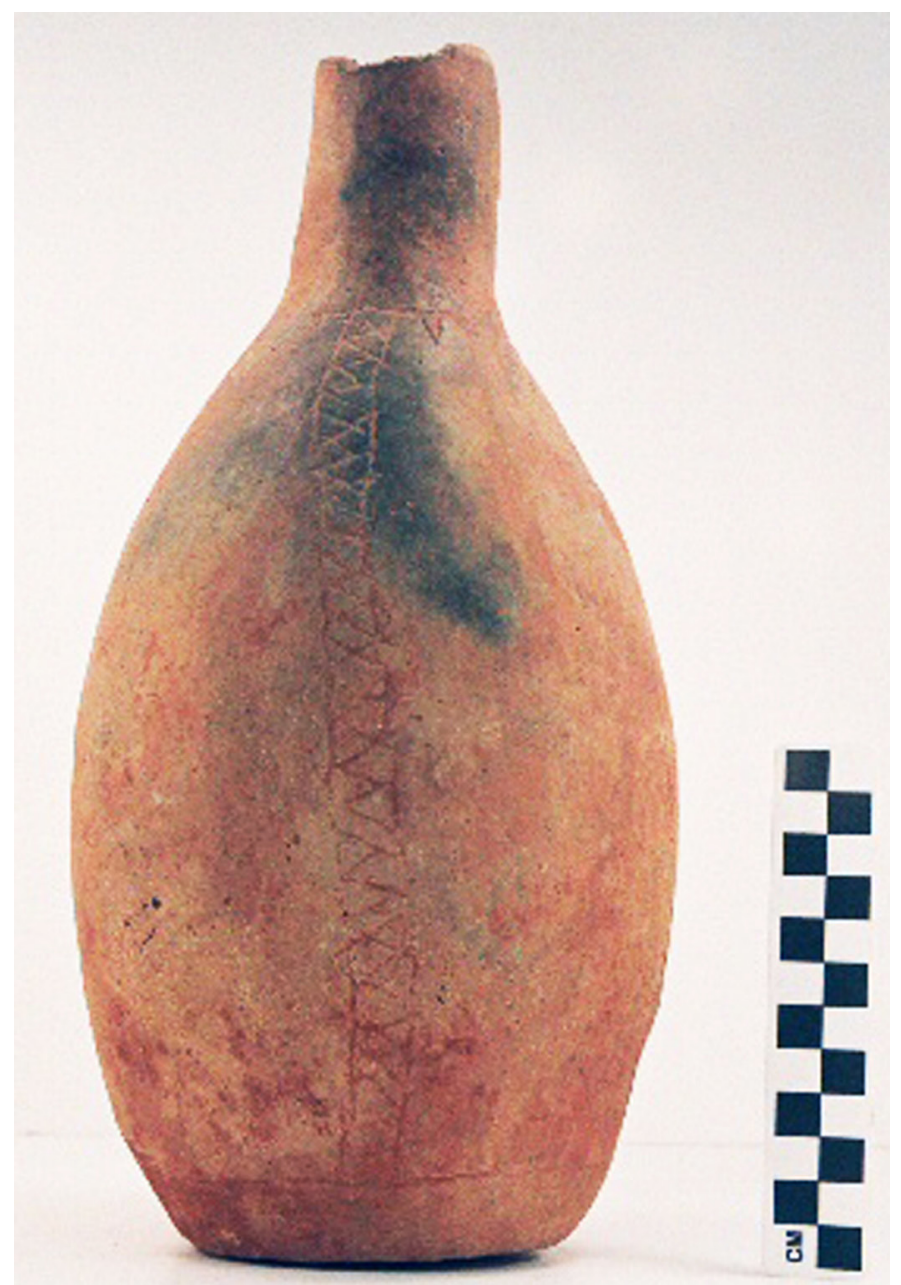

Figure 88. Hume Engraved, var. unspecified bottle from the Jim P. Allen site.

DECORATION (INCLUDING MOTIF AND ELEMENTS WHEN APPARENT): There are single horizontal engraved lines below the bottle neck and above the base. The upper horizontal engraved line has a series of cross-hatched engraved pendant triangles (Figure 88). Between the two horizontal lines are four vertical engraved bands filled with cross-hatched engraved lines.

PIGMENT USE AND LOCATION ON VESSEL: none

TYPE AND VARIETY [IF KNOWN]: Hume Engraved, var. unspecified 
SITE NAME OR SITE NUMBER: Jim P. Allen

VESSEL NO.: 41CE12-13; Burial AH-3

NON-PLASTICS AND PASTE: grog

VESSEL FORM: Bottle with cylindrical body and likely also a short neck (i.e., Hume Engraved bottle form)

RIM AND LIP FORM: N/A

CORE COLOR: F (fired in a reducing environment and cooled in the open air)

INTERIOR SURFACE COLOR: light brownishgray

EXTERIOR SURFACE COLOR: light brownishgray; fire clouds on the body

WALL THICKNESS (RIM, BODY, AND BASE IN MM): body, $5.5 \mathrm{~mm}$

INTERIOR SURFACE TREATMENT: none

EXTERIOR SURFACE TREATMENT: smoothed on the body

HEIGHT (IN CM): $15.0+$

ORIFICE DIAMETER (IN CM): 3.5

DIAMETER AT BOTTOM OF RIM OR NECK (IN CM): 4.6

BASE DIAMETER (IN CM) AND SHAPE OF BASE: 6.6; circular and flat

ESTIMATED VOLUME (IN LITERS): $>0.4$

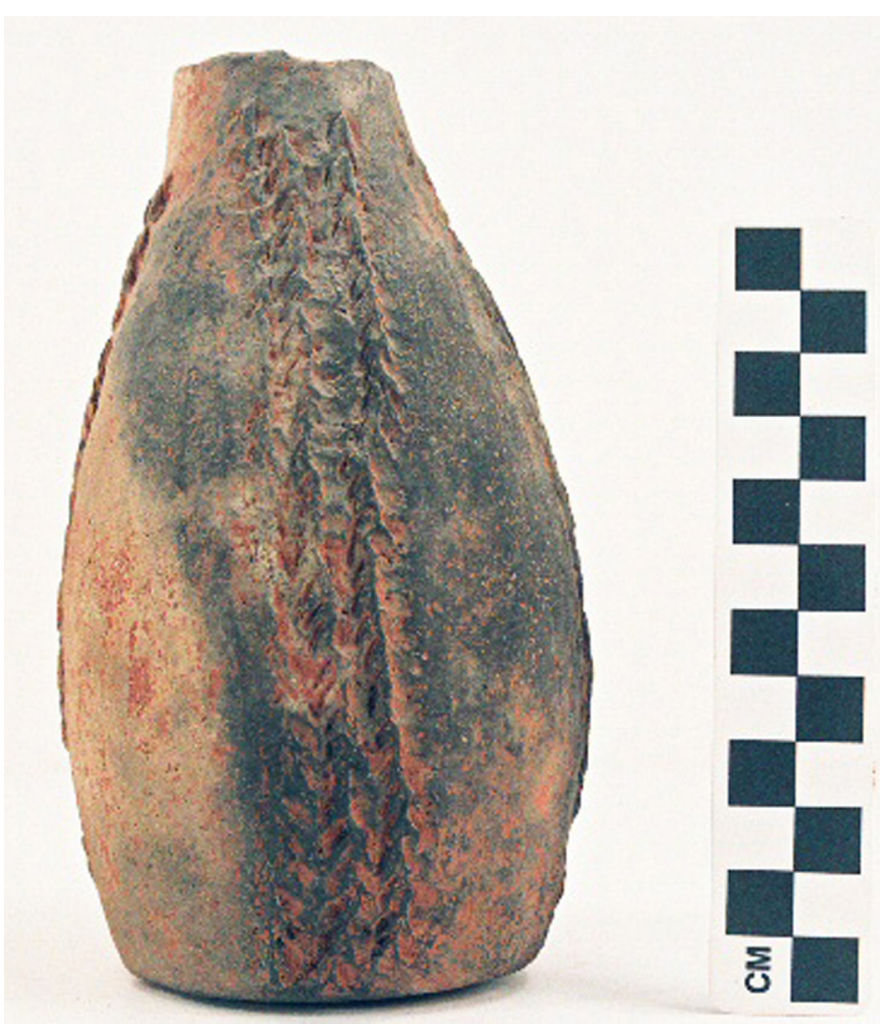

Figure 89. Killough Pinched, var. Allen bottle from the Jim P. Allen site.

DECORATION (INCLUDING MOTIF AND ELEMENTS WHEN APPARENT): There are four sets of three vertical pinched ridges on the vessel body that extend from the neck to the vessel base (Figure 89).

PIGMENT USE AND LOCATION ON VESSEL: none

TYPE AND VARIETY [IF KNOWN]: Killough Pinched, var. Allen 
SITE NAME OR SITE NUMBER: Jim P. Allen

VESSEL NO.: 41CE12-15; Burial AH-3

NON-PLASTICS AND PASTE: grog and hematite

VESSEL FORM: Globular bowl

RIM AND LIP FORM: Direct rim and rounded lip

CORE COLOR: $\mathrm{F}$ (fired in a reducing environment and cooled in the open air)

INTERIOR SURFACE COLOR: brown

EXTERIOR SURFACE COLOR: light brown; fire clouds on the rim and body

WALL THICKNESS (RIM, BODY, AND BASE IN MM): rim, $5.0 \mathrm{~mm}$

INTERIOR SURFACE TREATMENT: smoothed on the rim

EXTERIOR SURFACE TREATMENT:

smoothed to burnished on the rim and body

HEIGHT (IN CM): 18.0

ORIFICE DIAMETER (IN CM): 10.5

DIAMETER AT BOTTOM OF RIM OR NECK (IN CM): 10.1

BASE DIAMETER (IN CM) AND SHAPE OF

BASE: 8.0; circular and flat

ESTIMATED VOLUME (IN LITERS): 1.5

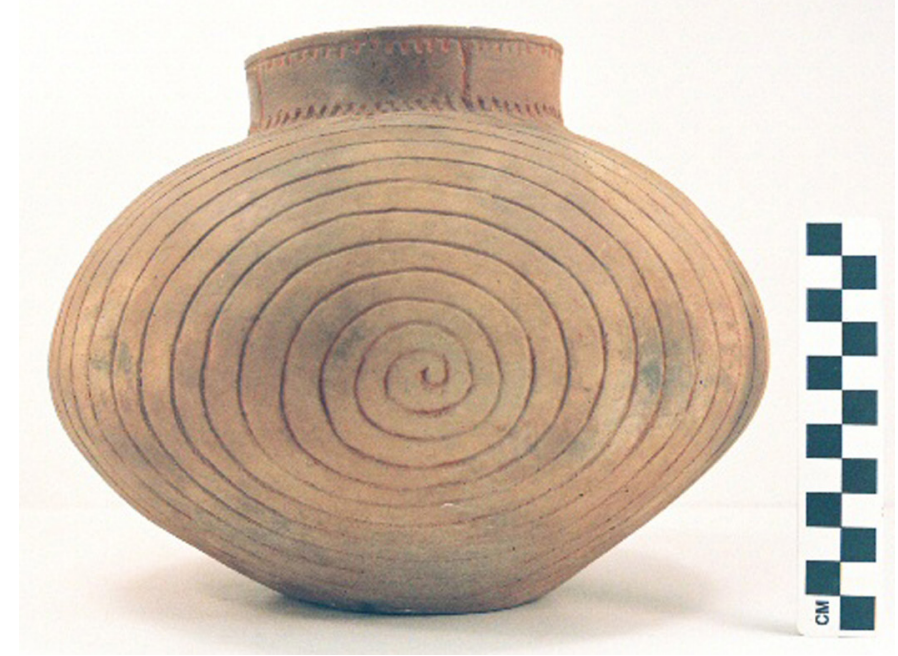

Figure 90. Poynor Engraved, var. Freeman globular bowl from the Jim P. Allen site.

DECORATION (INCLUDING MOTIF AND ELEMENTS WHEN APPARENT): The rim panel is defined by single upper and lower horizontal engraved lines with either downward- or upward-pointing excised tick marks. The rim panel is divided into four sections by excised brackets (Figure 90). The vessel body has two sets of concentric engraved spirals. There are faint linear tick marks on two of the lower concentric spirals on the vessel body.

PIGMENT USE AND LOCATION ON VESSEL: none

TYPE AND VARIETY [IF KNOWN]: Poynor Engraved, var. Freeman 
SITE NAME OR SITE NUMBER: Jim P. Allen

VESSEL NO.: 41CE12-16; Burial AH-3

NON-PLASTICS AND PASTE: grog and hematite

VESSEL FORM: Conjoined globular bowls

RIM AND LIP FORM: Direct rim and rounded lip

CORE COLOR: $\mathrm{G}$ (fired in a reducing environment and cooled in the open air)

INTERIOR SURFACE COLOR: grayish-brown

EXTERIOR SURFACE COLOR: light brown; fire clouds on the rim and body of both vessels

WALL THICKNESS (RIM, BODY, AND BASE

IN MM): rim, $4.1 \mathrm{~mm}$

INTERIOR SURFACE TREATMENT: smoothed on the body and burnished on the rim

EXTERIOR SURFACE TREATMENT: smoothed on the rim and body

HEIGHT (IN CM): 17.0

ORIFICE DIAMETER (IN CM): 8.2

DIAMETER AT BOTTOM OF RIM OR NECK (IN CM): $8.0 \mathrm{~cm}$ on the bottom vessel; $8.6 \mathrm{~cm}$ for the top vessel

\section{BASE DIAMETER (IN CM) AND SHAPE OF}

BASE: 6.8 ; circular and flat

ESTIMATED VOLUME (IN LITERS): 1.1

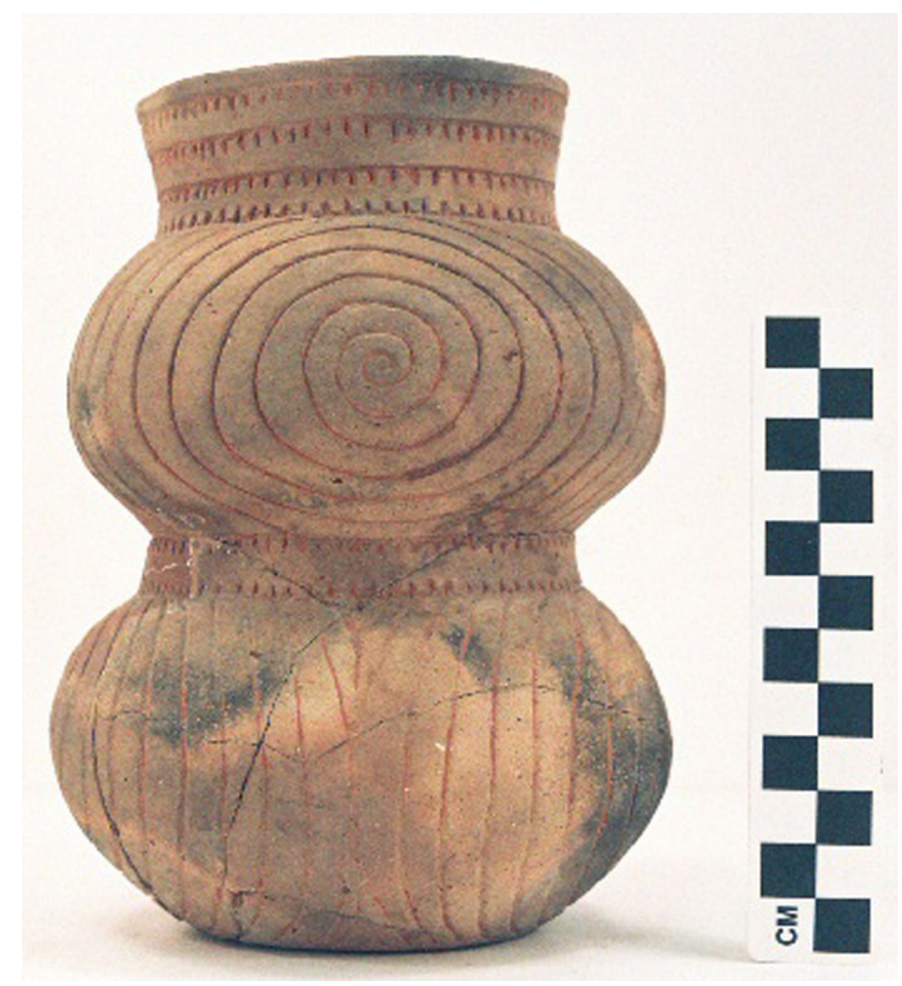

Figure 91. Poynor Engraved, var. Freeman conjoined globular bowls from the Jim P. Allen site.

DECORATION (INCLUDING MOTIF AND ELEMENTS WHEN APPARENT): The upper vessel has a rim panel defined by four horizontal engraved lines with either downward- or upward-pointing excised tick marks. The vessel body has three sets of engraved concentric spirals (Figure 91; see also Suhm and Jelks 1962:Plate 59d; they classify it as Patton Engraved, however). The lower conjoined vessel has a rim panel with two horizontal engraved lines with either downward- or upward-pointing excised tick marks. The vessel body has two sets of concentric engraved spirals, divided by upper and lower open triangles with small inner triangles (Figure 91). 
SITE NAME OR SITE NUMBER: Jim P. Allen

VESSEL NO.: 41CE12-17; Burial AH-3

NON-PLASTICS AND PASTE: grog

VESSEL FORM: Globular Bowl

RIM AND LIP FORM: Direct rim and rounded lip

CORE COLOR: A (fired and cooled in an oxidizing environment)

INTERIOR SURFACE COLOR: brown

EXTERIOR SURFACE COLOR: brown; fire clouds on the vessel body

WALL THICKNESS (RIM, BODY, AND BASE

IN MM): rim, $4.6 \mathrm{~mm}$

INTERIOR SURFACE TREATMENT: smoothed on the body and burnished on the rim

EXTERIOR SURFACE TREATMENT: smoothed on the rim and body

HEIGHT (IN CM): 9.8

ORIFICE DIAMETER (IN CM): 12.2

DIAMETER AT BOTTOM OF RIM OR NECK (IN CM): 13.0

BASE DIAMETER (IN CM) AND SHAPE OF

BASE: 7.4; circular and flat

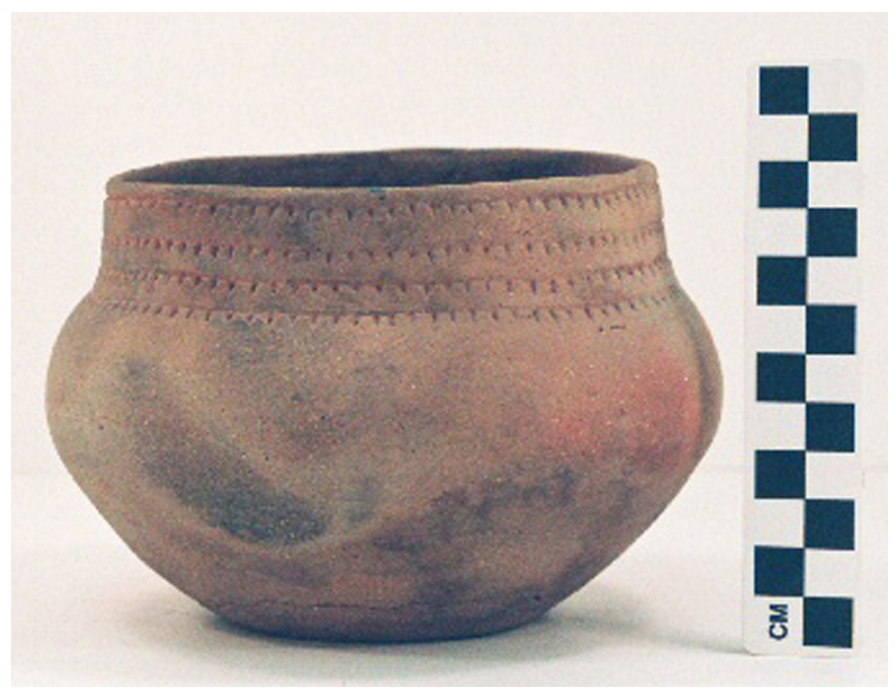

Figure 92. Patton Engraved, var. Allen globular bowl from the Jim P. Allen site.

ESTIMATED VOLUME (IN LITERS): 1.0

DECORATION (INCLUDING MOTIF AND ELEMENTS WHEN APPARENT): The rim has four horizontal engraved lines with downward-pointing excised tick marks (Figure 92).

PIGMENT USE AND LOCATION ON VESSEL: none

TYPE AND VARIETY [IF KNOWN]: Patton Engraved, var. Allen 
SITE NAME OR SITE NUMBER: Jim P. Allen

VESSEL NO.: 41CE12-63; Burial AH-4

NON-PLASTICS AND PASTE: grog

VESSEL FORM: Carinated Bowl

RIM AND LIP FORM: Direct rim and rounded lip; the bottom panel of the rim is inverted (Figure 93)

CORE COLOR: B (fired and cooled in a reducing environment)

INTERIOR SURFACE COLOR: dark grayish-brown

EXTERIOR SURFACE COLOR: grayish-brown; fire clouds

WALL THICKNESS (RIM, BODY, AND BASE IN MM): rim, $5.2 \mathrm{~mm}$

INTERIOR SURFACE TREATMENT: burnished on the rim and body

EXTERIOR SURFACE TREATMENT: burnished on the rim and body

HEIGHT (IN CM): 8.5

ORIFICE DIAMETER (IN CM): 16.5

DIAMETER AT BOTTOM OF RIM OR NECK (IN CM): 16.7

BASE DIAMETER (IN CM) AND SHAPE

OF BASE: 8.5; circular and flat

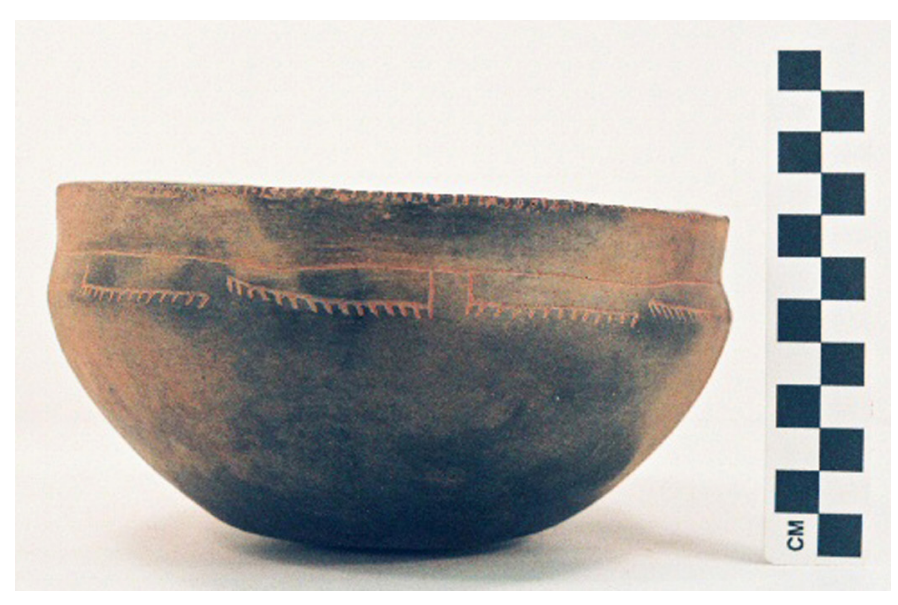

Figure 93. Simms Engraved, var. Darco carinated bowl from the Jim P. Allen site.

\section{ESTIMATED VOLUME (IN LITERS): 0.8}

DECORATION (INCLUDING MOTIF AND ELEMENTS WHEN APPARENT): The vessel is lip notched. The lower panel on the rim is defined by a single horizontal engraved line, and on the panel are 11 discontinuous and short diagonal or horizontal engraved scroll lines with linear tick marks and a vertical engraved line at one end of the scrolls (Figure 93).

PIGMENT USE AND LOCATION ON VESSEL: red pigment in engraved lines

TYPE AND VARIETY [IF KNOWN]: Simms Engraved, var. Darco 
SITE NAME OR SITE NUMBER: Jim P. Allen

VESSEL NO.: 41CE12-64; Burial AH-4

NON-PLASTICS AND PASTE: grog and hematite; fine sandy paste

VESSEL FORM: Globular Bowl

RIM AND LIP FORM: Direct rim and rounded lip

CORE COLOR: A (fired and cooled in an oxidizing environment)

INTERIOR SURFACE COLOR: brown

EXTERIOR SURFACE COLOR: strong brown; fire clouds on the body

WALL THICKNESS (RIM, BODY, AND BASE

IN MM): rim, $5.5 \mathrm{~mm}$

INTERIOR SURFACE TREATMENT: smoothed on the body and burnished on the rim

EXTERIOR SURFACE TREATMENT: smoothed on the body and burnished on the rim

HEIGHT (IN CM): 9.2

ORIFICE DIAMETER (IN CM): 11.2

DIAMETER AT BOTTOM OF RIM OR NECK (IN CM): 12.0

BASE DIAMETER (IN CM) AND SHAPE OF

BASE: 7.5; circular and flat
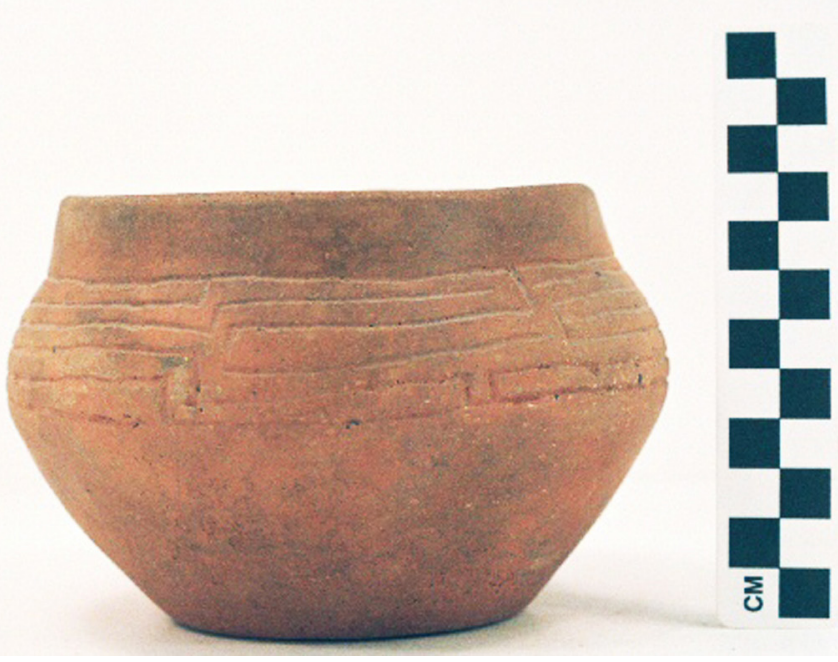

Figure 94. Unidentified engraved globular bowl, possibly Poynor Engraved, var. B, from the Jim $P$. Allen site.

ESTIMATED VOLUME (IN LITERS): 0.8

DECORATION (INCLUDING MOTIF AND ELEMENTS WHEN APPARENT): There is an engraved panel on the upper part of the vessel body defined by single upper and lower engraved lines. On the panel are six rectilinear engraved elements (Figure 94).

PIGMENT USE AND LOCATION ON VESSEL: none

TYPE AND VARIETY [IF KNOWN]: Unidentified fine ware, possibly Poynor Engraved, var. $B$ (see Figure 4) 
SITE NAME OR SITE NUMBER: Jim P. Allen

VESSEL NO.: 41CE12-66; Burial AH-5

NON-PLASTICS AND PASTE: bone

VESSEL FORM: Deep Bowl

RIM AND LIP FORM: Everted rim and rounded lip; lip notched

CORE COLOR: $\mathrm{F}$ (fired in a reducing environment and cooled in the open air)

INTERIOR SURFACE COLOR: brown; fire clouds on the rim and body

EXTERIOR SURFACE COLOR: brown

WALL THICKNESS (RIM, BODY, AND BASE IN MM): rim, $5.1 \mathrm{~mm}$

INTERIOR SURFACE TREATMENT: burnished on the rim and body

EXTERIOR SURFACE TREATMENT: burnished on the rim and body

HEIGHT (IN CM): 11.5

ORIFICE DIAMETER (IN CM): 16.5

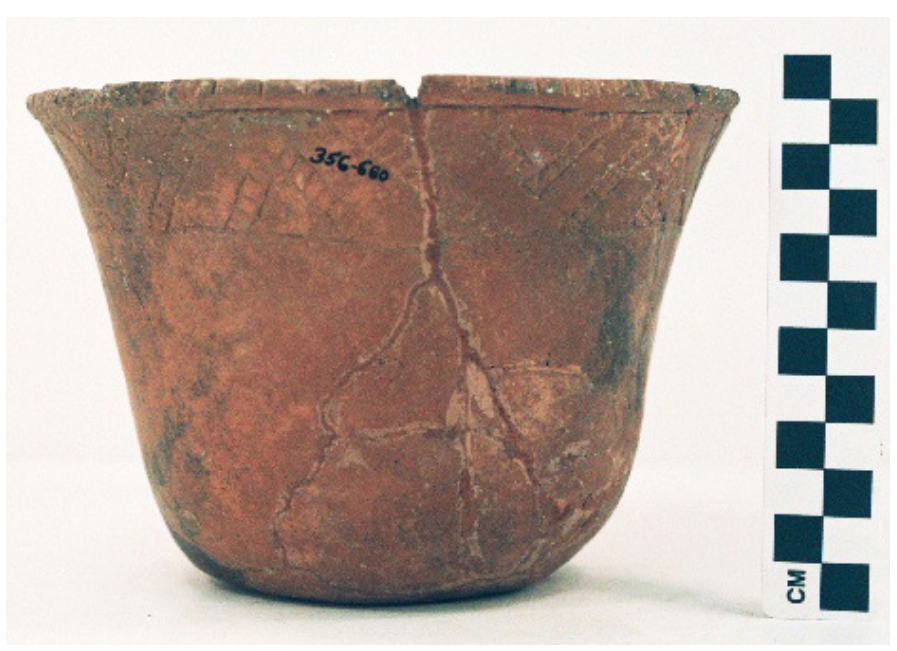

DIAMETER AT BOTTOM OF RIM OR NECK (IN CM): 13.6

Figure 95. cf. Avery Engraved deep bowl from the Jim P. Allen site.

BASE DIAMETER (IN CM) AND SHAPE OF BASE: 7.8; circular and flat

ESTIMATED VOLUME (IN LITERS): 1.5

DECORATION (INCLUDING MOTIF AND ELEMENTS WHEN APPARENT): The rim panel is defined by single upper and lower horizontal engraved lines. On the panel are five upper and five lower sets of hatched and open triangle elements (Figure 95). These triangle elements are divided by narrow hatched diagonal zones.

PIGMENT USE AND LOCATION ON VESSEL: none

TYPE AND VARIETY [IF KNOWN]: cf. Avery Engraved 
SITE NAME OR SITE NUMBER: Jim P. Allen

VESSEL NO.: 41CE12-67; Burial AH-5

NON-PLASTICS AND PASTE: grog

VESSEL FORM: Poorly made bowl

RIM AND LIP FORM: Direct rim and rounded lip

CORE COLOR: A (fired and cooled in an oxidizing environment)

INTERIOR SURFACE COLOR: light brown

EXTERIOR SURFACE COLOR: brown

WALL THICKNESS (RIM, BODY, AND BASE

IN MM): rim, $7.7 \mathrm{~mm}$

INTERIOR SURFACE TREATMENT: smoothed on the body and rim

EXTERIOR SURFACE TREATMENT: none

HEIGHT (IN CM): 8.5

ORIFICE DIAMETER (IN CM): 10.8

DIAMETER AT BOTTOM OF RIM OR NECK

(IN CM): N/A

BASE DIAMETER (IN CM) AND SHAPE OF

BASE: 6.5 ; circular and flat

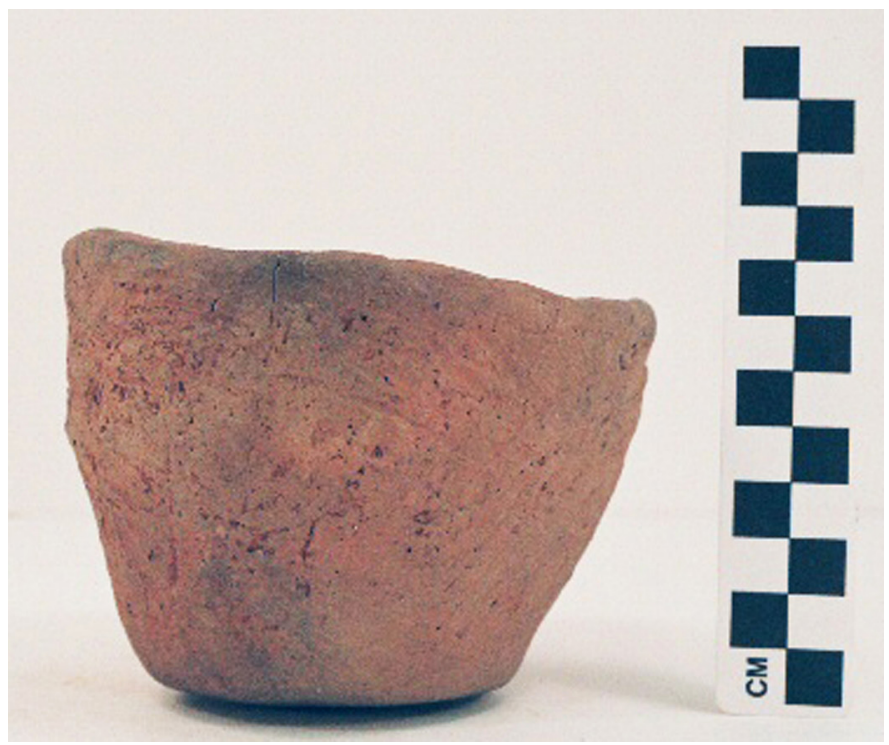

Figure 96. Brushed bowl from the Jim P. Allen site.

ESTIMATED VOLUME (IN LITERS): 0.4

DECORATION (INCLUDING MOTIF AND ELEMENTS WHEN APPARENT): The vessel has diagonal, opposed, and overlapping brushed marks on the rim and body (Figure 96).

PIGMENT USE AND LOCATION ON VESSEL: none

TYPE AND VARIETY [IF KNOWN]: Unidentified utility ware 
SITE NAME OR SITE NUMBER: Jim P. Allen

VESSEL NO.: 41CE12-68; Burial AH-6

NON-PLASTICS AND PASTE: grog

VESSEL FORM: Carinated Bowl

RIM AND LIP FORM: Inverted rim and rounded lip; lip notched

CORE COLOR: A (fired and cooled in an oxidizing environment)

INTERIOR SURFACE COLOR: light yellowishbrown

EXTERIOR SURFACE COLOR: yellowish-red

WALL THICKNESS (RIM, BODY, AND BASE

IN MM): rim, $4.6 \mathrm{~mm}$

INTERIOR SURFACE TREATMENT: smoothed on the rim and body

EXTERIOR SURFACE TREATMENT: burnished on the rim and body

HEIGHT (IN CM): 4.5

ORIFICE DIAMETER (IN CM): 7.0

DIAMETER AT BOTTOM OF RIM OR NECK (IN CM): 7.4

BASE DIAMETER (IN CM) AND SHAPE OF BASE: 4.0 ; circular and flat

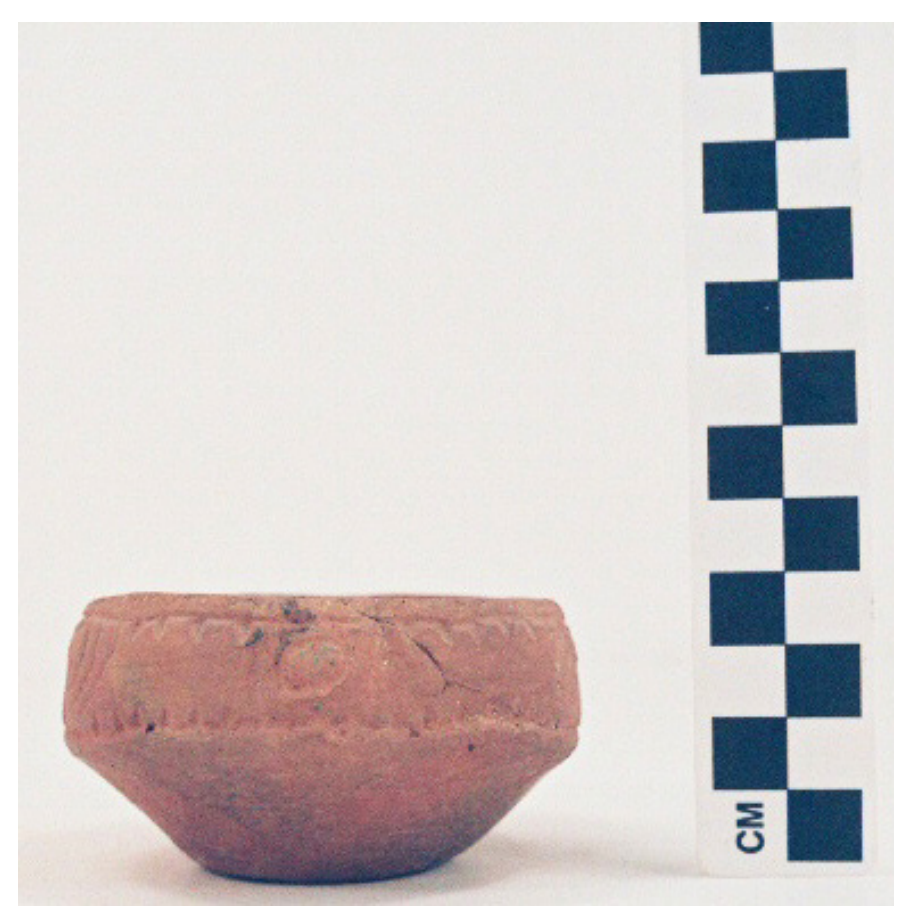

Figure 97. Patton Engraved, var. unspecified carinated bowl from the Jim P. Allen site.

ESTIMATED VOLUME (IN LITERS): 0.2

DECORATION (INCLUDING MOTIF AND ELEMENTS WHEN APPARENT): The rim panel is defined by single upper and lower horizontal engraved lines with either downward- or upward-pointing excised tick marks. On the panel are two concentric circle elements, another with three opposed curvilinear engraved lines, and a fourth element with a central circle, opposed curvilinear lines, and opposed semi-circular engraved lines (Figure 97).

PIGMENT USE AND LOCATION ON VESSEL: white pigment in engraved lines

TYPE AND VARIETY [IF KNOWN]: Patton Engraved, var. unspecified 
SITE NAME OR SITE NUMBER: Jim P. Allen

VESSEL NO.: 41CE12-69; Burial AH-6

NON-PLASTICS AND PASTE: bone and grog

VESSEL FORM: Globular Bowl

RIM AND LIP FORM: Direct rim and rounded lip; lip notched

CORE COLOR: B (fired and cooled in a reducing environment)

INTERIOR SURFACE COLOR: dark gray; fire clouds

EXTERIOR SURFACE COLOR: dark gray; fire clouds on the rim and body

WALL THICKNESS (RIM, BODY, AND BASE IN MM): rim, $4.4 \mathrm{~mm}$

INTERIOR SURFACE TREATMENT: burnished on the rim and body

EXTERIOR SURFACE TREATMENT:

burnished on the rim and body

HEIGHT (IN CM): 8.6

ORIFICE DIAMETER (IN CM): 14.5

DIAMETER AT BOTTOM OF RIM

OR NECK (IN CM): 14.5

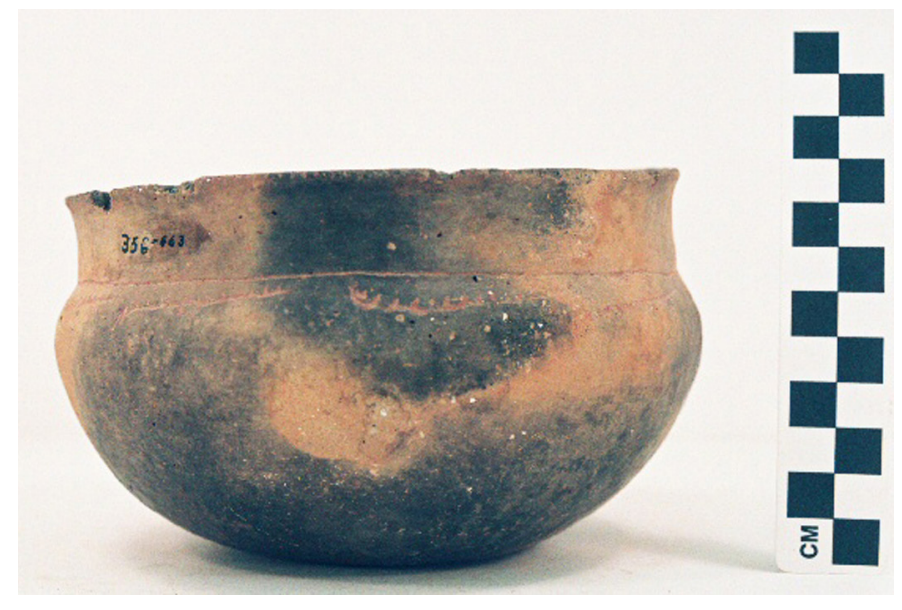

Figure 98. Simms Engraved, var. Darco globular bowl from the Jim P. Allen site.

BASE DIAMETER (IN CM) AND SHAPE OF BASE: 6.0; circular and flat

ESTIMATED VOLUME (IN LITERS): 1.0

DECORATION (INCLUDING MOTIF AND ELEMENTS WHEN APPARENT): The vessel is lip notched. The rim is plain. The decorated panel on the upper vessel body is defined by a single horizontal engraved line, and on the panel are nine discontinuous and short diagonal engraved scroll lines with linear tick marks pointing either upwards $(n=5)$, downwards $(n=3)$, or in both directions $(n=1)$ (Figure 98).

PIGMENT USE AND LOCATION ON VESSEL: red pigment in engraved lines

TYPE AND VARIETY [IF KNOWN]: Simms Engraved, var. Darco 
SITE NAME OR SITE NUMBER: Jim P. Allen

VESSEL NO.: 41CE12-70; Burial AH-6

NON-PLASTICS AND PASTE: grog

VESSEL FORM: Bottle

RIM AND LIP FORM: Direct rim and flat lip

CORE COLOR: A (fired and cooled in an oxidizing environment)

INTERIOR SURFACE COLOR: reddish-yellow

EXTERIOR SURFACE COLOR: reddish-yellow

WALL THICKNESS (RIM, BODY, AND BASE

IN MM): rim, $5.7 \mathrm{~mm}$

INTERIOR SURFACE TREATMENT: none

EXTERIOR SURFACE TREATMENT: smoothed on the neck and body

HEIGHT (IN CM): 13.6

ORIFICE DIAMETER (IN CM): 3.8

DIAMETER AT BOTTOM OF RIM OR NECK (IN CM): 5.3

BASE DIAMETER (IN CM) AND SHAPE OF BASE: 6.8; circular and flat

ESTIMATED VOLUME (IN LITERS): 0.4

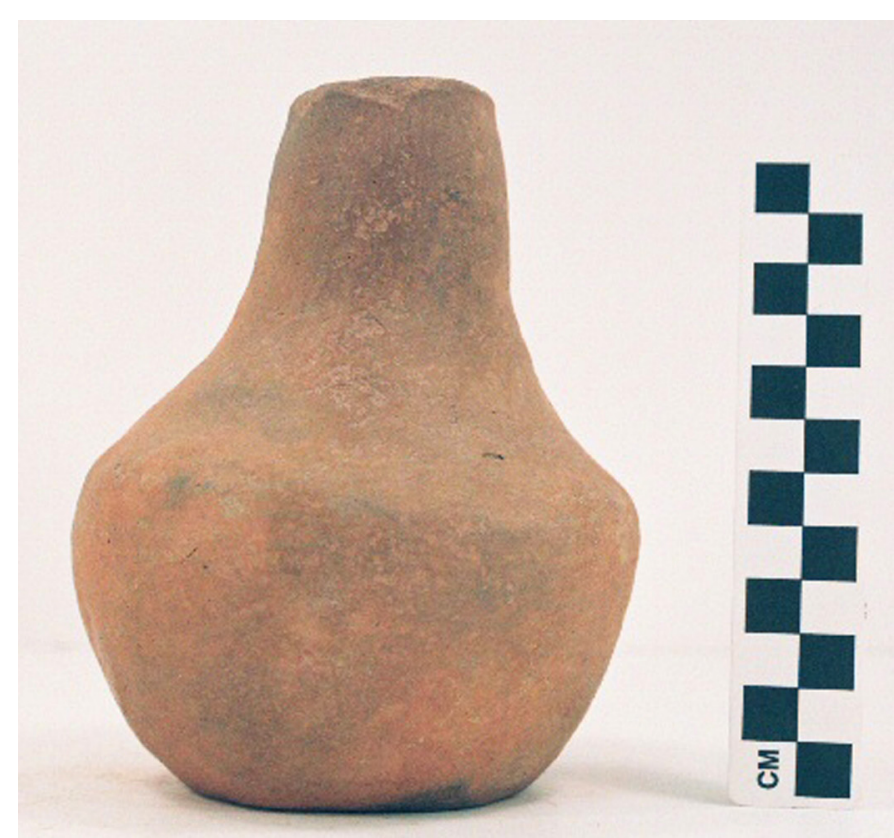

Figure 99. Plain bottle from the Jim P. Allen site.

DECORATION (INCLUDING MOTIF AND ELEMENTS WHEN APPARENT): Plain (Figure 99)

PIGMENT USE AND LOCATION ON VESSEL: none

TYPE AND VARIETY [IF KNOWN]: Unidentified plain ware 
SITE NAME OR SITE NUMBER: Jim P. Allen

VESSEL NO.: 41CE12-71

NON-PLASTICS AND PASTE: grog and hematite

VESSEL FORM: Bottle with a cylindrical body and a short neck

RIM AND LIP FORM: Direct rim and rounded lip

CORE COLOR: $\mathrm{F}$ (fired in a reducing environment and cooled in the open air)

INTERIOR SURFACE COLOR: brown; fire clouds on the body

EXTERIOR SURFACE COLOR: brownish-yellow; fire clouds on the body

WALL THICKNESS (RIM, BODY, AND BASE IN MM): neck, $7.2 \mathrm{~mm}$

INTERIOR SURFACE TREATMENT: none

EXTERIOR SURFACE TREATMENT: smoothed on the neck and base

HEIGHT (IN CM): 20.4

ORIFICE DIAMETER (IN CM): 4.5

DIAMETER AT BOTTOM OF RIM OR NECK (IN $\mathrm{CM}): 4.8 ; 9.5 \mathrm{~cm}$ at maximum width on the body

BASE DIAMETER (IN CM) AND SHAPE OF

BASE: 9.0; circular and flat

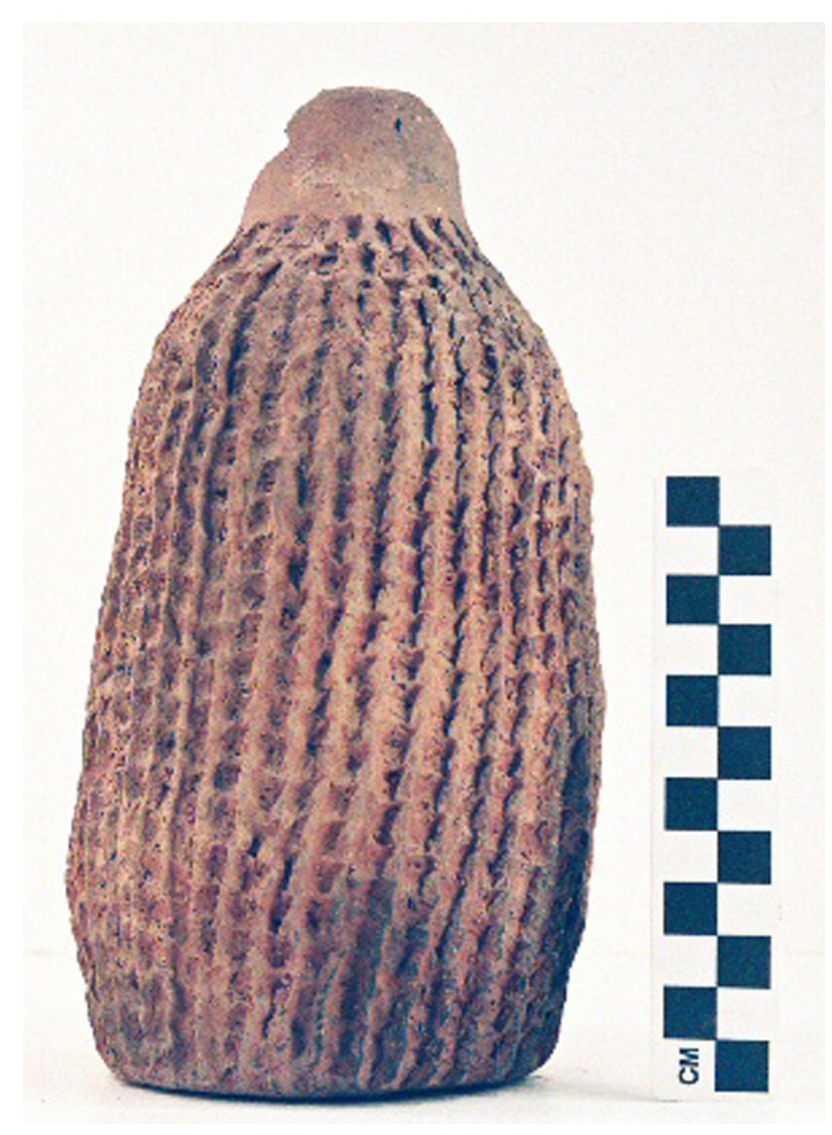

Figure 100. Killough Pinched, var. Allen bottle from the Jim P. Allen site.

ESTIMATED VOLUME (IN LITERS): 0.7

DECORATION (INCLUDING MOTIF AND ELEMENTS WHEN APPARENT): The vessel body is completely covered with vertical pinched ridges (Figure 100).

PIGMENT USE AND LOCATION ON VESSEL: none

TYPE AND VARIETY [IF KNOWN]: Killough Pinched, var. Allen 
SITE NAME OR SITE NUMBER: Jim P. Allen

VESSEL NO.: 41CE12-76; Burial AH-7

NON-PLASTICS AND PASTE: grog and hematite

VESSEL FORM: Large bowl or carinated bowl

RIM AND LIP FORM: N/A

CORE COLOR: A (fired and cooled in an oxidizing environment)

INTERIOR SURFACE COLOR: brown; fire clouds on the base

EXTERIOR SURFACE COLOR: strong brown

WALL THICKNESS (RIM, BODY, AND BASE IN MM): body, $6.2 \mathrm{~mm}$

INTERIOR SURFACE TREATMENT: smoothed on the body

EXTERIOR SURFACE TREATMENT: none

HEIGHT (IN CM): $12.3 \mathrm{~cm}$ body height

ORIFICE DIAMETER (IN CM): N/A

DIAMETER AT BOTTOM OF RIM OR NECK

(IN CM): $25.0 \mathrm{~cm}$ at its widest part of the body

BASE DIAMETER (IN CM) AND SHAPE OF

BASE: 11.5; circular and flat

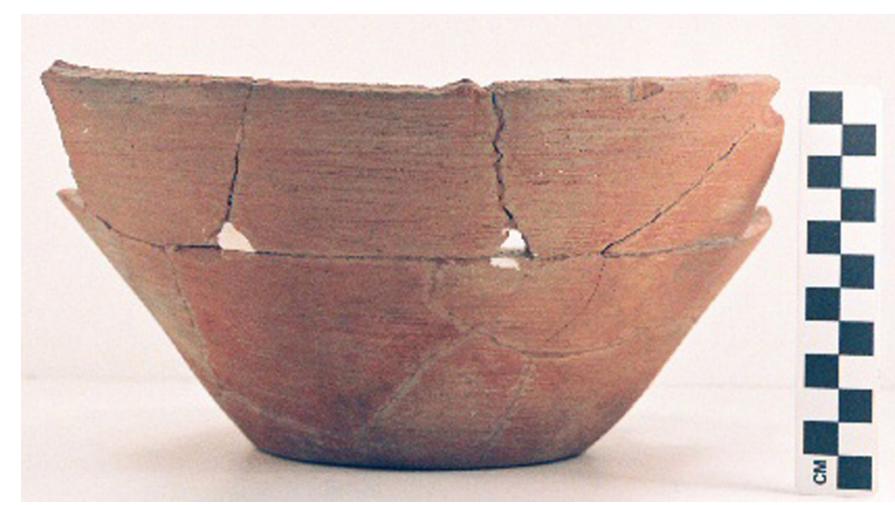

Figure 101. Brushed vessel body section to a carinated bowl or large bowl of an unidentified ceramic type.

ESTIMATED VOLUME (IN LITERS): N/A

DECORATION (INCLUDING MOTIF AND ELEMENTS WHEN APPARENT): The vessel body has horizontal brushing marks (Figure 101). It is likely that this is the body to a Patton Engraved carinated bowl.

PIGMENT USE AND LOCATION ON VESSEL: none

TYPE AND VARIETY [IF KNOWN]: Unidentified 
SITE NAME OR SITE NUMBER: Jim P. Allen

VESSEL NO.: 41CE12-132; Burial AH-10

NON-PLASTICS AND PASTE: hematite; sandy paste

VESSEL FORM: Bottle with a cylindrical body and a short neck

RIM AND LIP FORM: Inverted rim and rounded lip

CORE COLOR: A (fired and cooled in an oxidizing environment)

INTERIOR SURFACE COLOR: very pale brown

EXTERIOR SURFACE COLOR: very pale brown

WALL THICKNESS (RIM, BODY, AND BASE IN

MM): rim, $7.1 \mathrm{~mm}$

INTERIOR SURFACE TREATMENT: none

EXTERIOR SURFACE TREATMENT: smoothed on the neck, body, and base

HEIGHT (IN CM): 20.0

ORIFICE DIAMETER (IN CM): 3.2

DIAMETER AT BOTTOM OF RIM OR NECK (IN $\mathrm{CM}$ ): 12.0 at the widest point on the body

BASE DIAMETER (IN CM) AND SHAPE OF

BASE: 7.8; circular and flat

ESTIMATED VOLUME (IN LITERS): 0.6

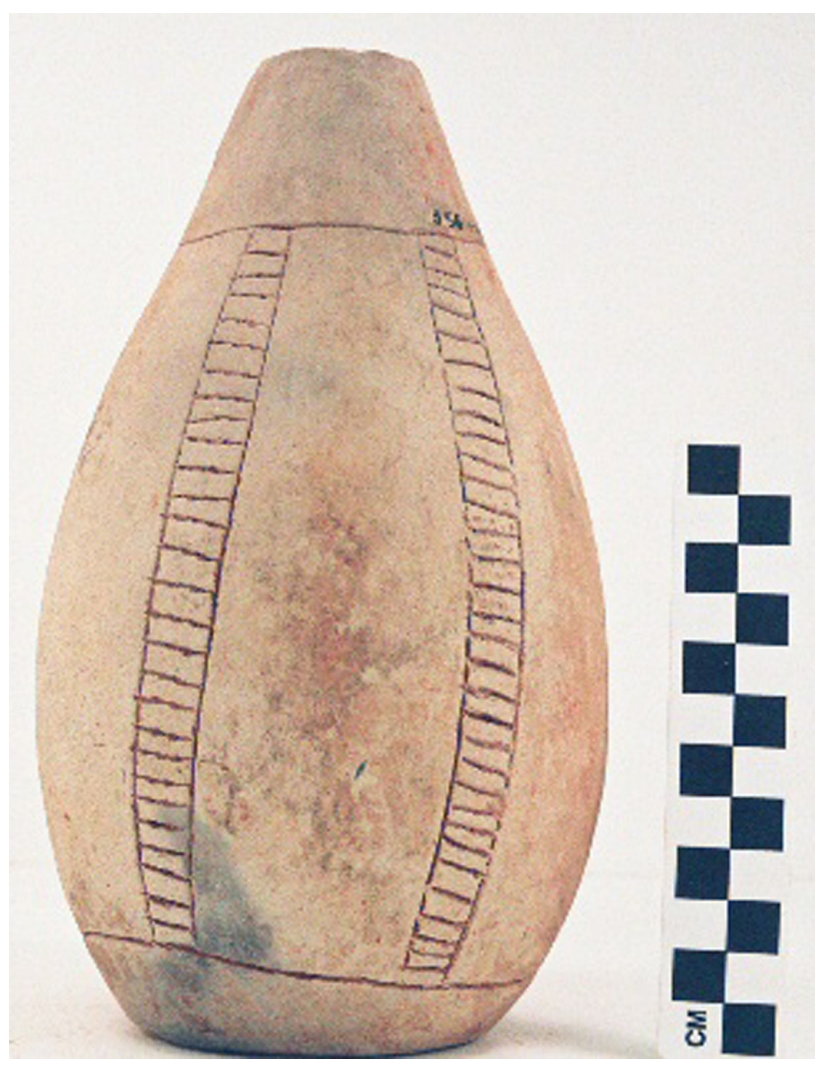

Figure 102. cf. Hume Engraved, var. unspecified bottle from the Jim P. Allen site.

DECORATION (INCLUDING MOTIF AND ELEMENTS WHEN APPARENT): There are single horizontal incised, rather than engraved, lines below the bottle neck and above the vessel base. Between these lines are five narrow vertical zones filled with a series of horizontal incised lines (Figure 102).

PIGMENT USE AND LOCATION ON VESSEL: none

TYPE AND VARIETY [IF KNOWN]: cf. Hume Engraved, var. unspecified 
SITE NAME OR SITE NUMBER: Jim P. Allen

VESSEL NO.: 41CE12-136; Burial AH-8

NON-PLASTICS AND PASTE: grog and bone

VESSEL FORM: Carinated bowl with upper and lower panels

RIM AND LIP FORM: Everted rim and rounded lip

CORE COLOR: B (fired and cooled in a reducing environment)

INTERIOR SURFACE COLOR: very dark grayish-brown

EXTERIOR SURFACE COLOR: dark brown

WALL THICKNESS (RIM, BODY, AND BASE

IN MM): rim, $5.4 \mathrm{~mm}$

INTERIOR SURFACE TREATMENT: smoothed

EXTERIOR SURFACE TREATMENT: burnished

HEIGHT (IN CM): 8.2

ORIFICE DIAMETER (IN CM): 15.3

DIAMETER AT BOTTOM OF RIM OR NECK

(IN CM): $16.4 \mathrm{~cm}$ at the widest part of the body

BASE DIAMETER (IN CM) AND SHAPE OF

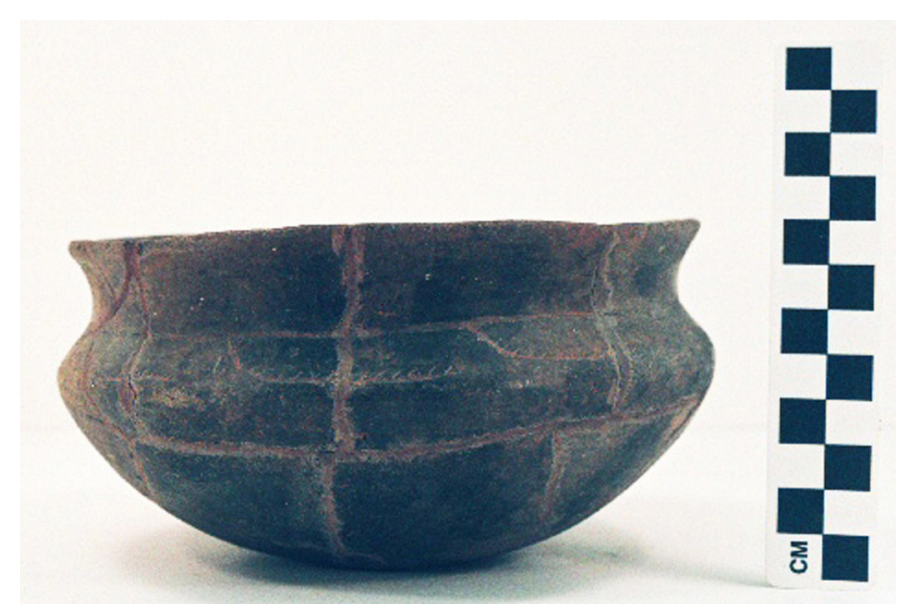

Figure 103. Simms Engraved, var. Darco carinated bowl from the Jim P. Allen site.

BASE: 7.0; circular and flat

ESTIMATED VOLUME (IN LITERS): 0.8

DECORATION (INCLUDING MOTIF AND ELEMENTS WHEN APPARENT): The lip of the vessel is notched. The upper rim panel is plain, but the lower rim panel has a series of eight discontinuous scroll lines with linear tick marks (Figure 103).

PIGMENT USE AND LOCATION ON VESSEL: none

TYPE AND VARIETY [IF KNOWN]: Simms Engraved, var. Darco 
SITE NAME OR SITE NUMBER: Jim P. Allen

VESSEL NO.: 41CE12-138; Burial AH-9

NON-PLASTICS AND PASTE: grog and hematite

VESSEL FORM: Globular Bowl

RIM AND LIP FORM: Direct rim and rounded lip

CORE COLOR: A (fired and cooled in an oxidizing environment)

INTERIOR SURFACE COLOR: light yellowish-brown

EXTERIOR SURFACE COLOR: light yellowishbrown; fire clouds on the rim, body, and base

WALL THICKNESS (RIM, BODY, AND BASE

IN MM): rim, $4.3 \mathrm{~mm}$

INTERIOR SURFACE TREATMENT: smoothed

EXTERIOR SURFACE TREATMENT: smoothed on the rim and body

HEIGHT (IN CM): 9.0

ORIFICE DIAMETER (IN CM): 9.5

DIAMETER AT BOTTOM OF RIM OR NECK (IN CM): 9.5

BASE DIAMETER (IN CM) AND SHAPE OF

BASE: 5.4; circular and flat

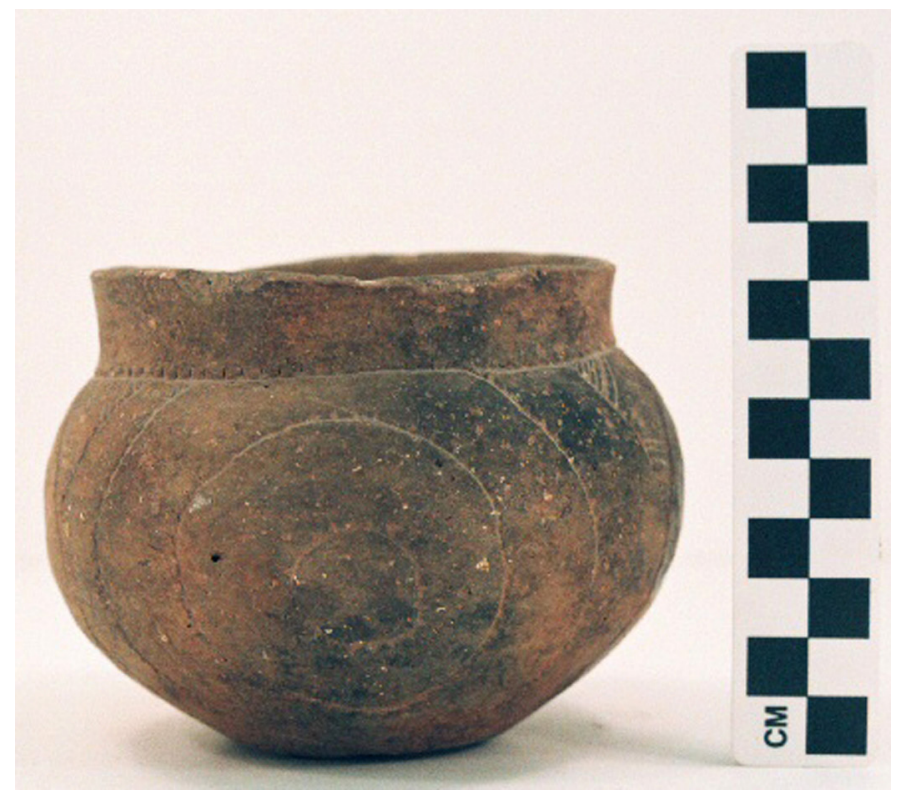

Figure 104. cf. Patton Engraved, var. Fair globular bowl from the Jim P. Allen site.

\section{ESTIMATED VOLUME (IN LITERS): 0.7}

DECORATION (INCLUDING MOTIF AND ELEMENTS WHEN APPARENT): The rim has a single horizontal engraved line with upward-pointing excised tick marks at the base of the rim. The vessel body has three sets of engraved concentric circles, with each line of the circles having outward-pointing excised tick marks (Figure 104). The concentric circles begin from the apex of three large pendant triangles with hatched corners, and part of the first concentric circle line does not have tick marks on it.

PIGMENT USE AND LOCATION ON VESSEL: none

TYPE AND VARIETY [IF KNOWN]: cf. Patton Engraved, var. Fair 
SITE NAME OR SITE NUMBER: Jim P. Allen

VESSEL NO.: 41CE12-161; Burial AH-11

NON-PLASTICS AND PASTE: grog and hematite

VESSEL FORM: Globular Bowl

RIM AND LIP FORM: Direct rim and rounded lip

CORE COLOR: A (fired and cooled in an oxidizing environment)

INTERIOR SURFACE COLOR: strong brown

EXTERIOR SURFACE COLOR: strong brown; fire clouds on the rim, body, and base

WALL THICKNESS (RIM, BODY, AND BASE IN MM): rim, $5.2 \mathrm{~mm}$

INTERIOR SURFACE TREATMENT: smoothed

EXTERIOR SURFACE TREATMENT: smoothed

HEIGHT (IN CM): 10.5

ORIFICE DIAMETER (IN CM): 12.2

DIAMETER AT BOTTOM OF RIM OR NECK (IN CM): $15.8 \mathrm{~cm}$ at the widest part of the body

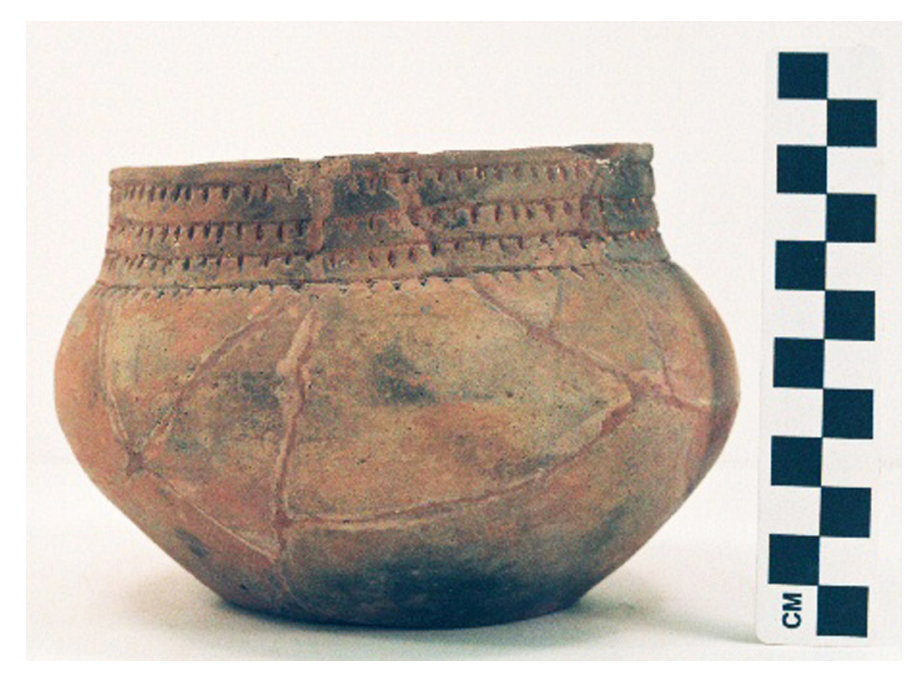

Figure 105. Patton Engraved, var. Allen globular bowl from the Jim P. Allen site.

BASE DIAMETER (IN CM) AND SHAPE OF BASE: 8.2; circular and flat

ESTIMATED VOLUME (IN LITERS): 1.0

DECORATION (INCLUDING MOTIF AND ELEMENTS WHEN APPARENT): The rim has four horizontal engraved lines with downward-pointing excised tick marks (Figure 105).

PIGMENT USE AND LOCATION ON VESSEL: white pigment in the engraved lines

TYPE AND VARIETY [IF KNOWN]: Patton Engraved, var. Allen 
SITE NAME OR SITE NUMBER: Jim P. Allen

VESSEL NO.: 41CE12-162; Burial AH-11

NON-PLASTICS AND PASTE: grog

VESSEL FORM: Jar

RIM AND LIP FORM: N/A

CORE COLOR: $\mathrm{H}$ (fired in a reducing environment and cooled in the open air)

INTERIOR SURFACE COLOR: brown

EXTERIOR SURFACE COLOR: very dark gray; organic residue on the vessel body

WALL THICKNESS (RIM, BODY, AND BASE IN MM): $8.0 \mathrm{~mm}$, body

INTERIOR SURFACE TREATMENT: smoothed on the body

EXTERIOR SURFACE TREATMENT: none

HEIGHT (IN CM): N/A

ORIFICE DIAMETER (IN CM): 8.0

DIAMETER AT BOTTOM OF RIM OR NECK (IN CM): N/A

BASE DIAMETER (IN CM) AND SHAPE OF

BASE: 5.0; circular and flat

ESTIMATED VOLUME (IN LITERS): N/A
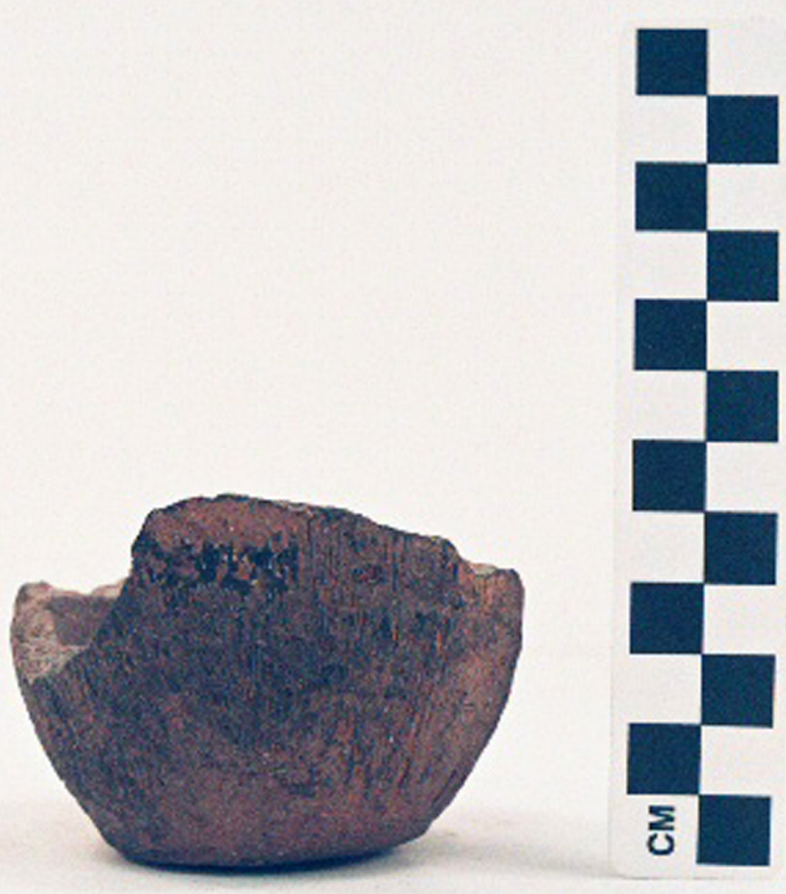

Figure 106. cf. Bullard Brushed jar vessel section from the Jim P. Allen site.

DECORATION (INCLUDING MOTIF AND ELEMENTS WHEN APPARENT): The body section has vertical and overlapping brushing marks (Figure 106).

PIGMENT USE AND LOCATION ON VESSEL: none

TYPE AND VARIETY [IF KNOWN]: cf. Bullard Brushed 
SITE NAME OR SITE NUMBER: Jim P. Allen

VESSEL NO.: 41CE12-164; Burial AH-12

NON-PLASTICS AND PASTE: grog and hematite

VESSEL FORM: Bottle with a cylindrical body

RIM AND LIP FORM: N/A

CORE COLOR: A (fired and cooled in an oxidizing environment)

INTERIOR SURFACE COLOR: yellowish-brown

EXTERIOR SURFACE COLOR: yellowish-brown; fire clouds on the body and base

WALL THICKNESS (RIM, BODY, AND BASE IN MM): body, $6.7 \mathrm{~mm}$

INTERIOR SURFACE TREATMENT: none

EXTERIOR SURFACE TREATMENT: smoothed on the body and base

HEIGHT (IN CM): > 14.5

ORIFICE DIAMETER (IN CM): 11.8

DIAMETER AT BOTTOM OF RIM OR NECK (IN CM): N/A

BASE DIAMETER (IN CM) AND SHAPE OF

BASE: 9.2; circular and flat

ESTIMATED VOLUME (IN LITERS): 0.6

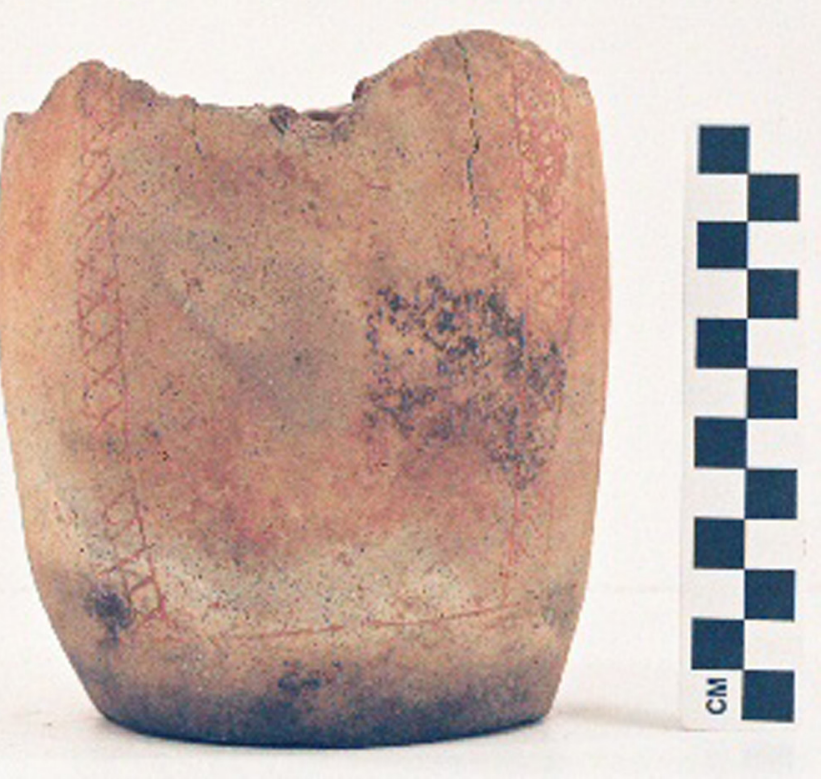

Figure 107. Hume Engraved, var. unspecified bottle section from the Jim P. Allen site.

DECORATION (INCLUDING MOTIF AND ELEMENTS WHEN APPARENT): There is a single horizontal engraved line near the vessel base, as well as four vertical zones or bands filled with crosshatched engraved lines (Figure 107).

PIGMENT USE AND LOCATION ON VESSEL: none

TYPE AND VARIETY [IF KNOWN]: Hume Engraved, var. unspecified 
SITE NAME OR SITE NUMBER: Jim P. Allen

VESSEL NO.: 41CE12-165; Burial AH-12

NON-PLASTICS AND PASTE: grog and hematite

VESSEL FORM: Globular Bowl

RIM AND LIP FORM: Direct rim and rounded lip

CORE COLOR: A (fired and cooled in an oxidizing environment)

INTERIOR SURFACE COLOR: yellowish-brown; fire clouds on the base

EXTERIOR SURFACE COLOR: brownish-yellow; fire clouds on the rim, body, and base

WALL THICKNESS (RIM, BODY, AND BASE

IN MM): rim, $5.3 \mathrm{~mm}$

INTERIOR SURFACE TREATMENT: smoothed on the rim and body

EXTERIOR SURFACE TREATMENT: smoothed on the rim and body

HEIGHT (IN CM): 11.7

ORIFICE DIAMETER (IN CM): 13.1

DIAMETER AT BOTTOM OF RIM OR NECK (IN CM): $14.6 \mathrm{~cm}$ at the widest part of the body

BASE DIAMETER (IN CM) AND SHAPE OF

BASE: 6.0 ; circular and flat

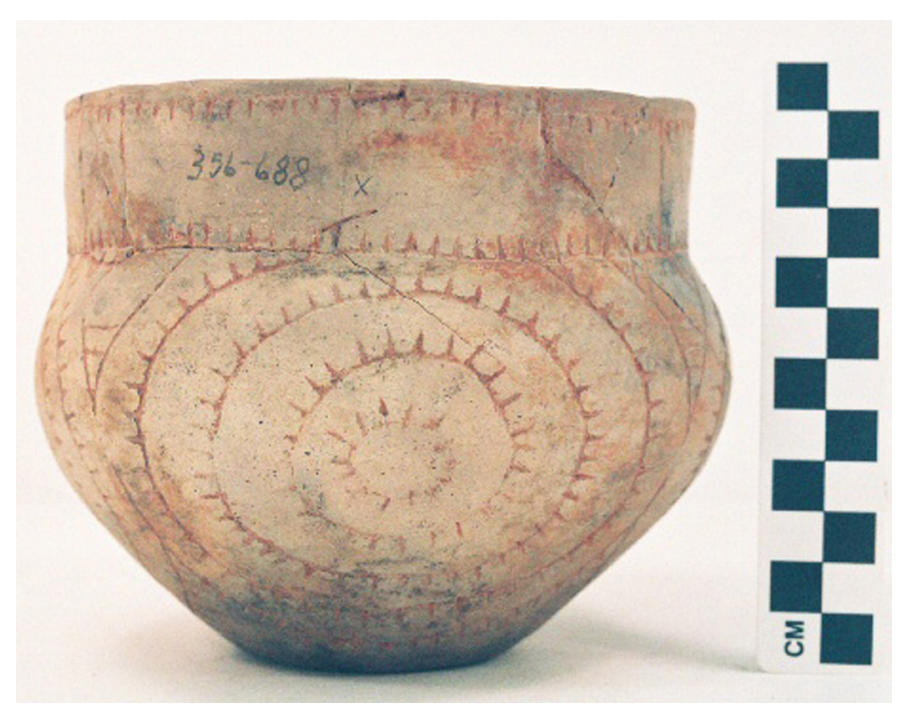

Figure 108.cf. Patton Engraved, var. Freeman globular bowl from the Jim P. Allen site.

ESTIMATED VOLUME (IN LITERS): 1.2

DECORATION (INCLUDING MOTIF AND ELEMENTS WHEN APPARENT): The rim panel is defined by single upper and lower horizontal engraved lines with either downward- or upward-pointing excised tick marks. The panel is divided into three sections by single vertical engraved lines (Figure 108). The vessel body has three sets of engraved concentric circles with outward-pointing tick marks. The sets of concentric circles are divided at their upper ends by large pendant triangles with hatched corners (Figure 108).

PIGMENT USE AND LOCATION ON VESSEL: none

TYPE AND VARIETY [IF KNOWN]: cf. Patton Engraved, var. Freeman 
SITE NAME OR SITE NUMBER: Jim P. Allen

VESSEL NO.: 41CE12-167; Burial AH-13

NON-PLASTICS AND PASTE: grog and hematite

VESSEL FORM: Bottle with a cylindrical body and short neck (i.e., Hume Engraved form, see Suhm and Jelks 1962:Plate 42a-c, e)

RIM AND LIP FORM: Direct rim and flat lip

CORE COLOR: A (fired and cooled in an oxidizing environment)

INTERIOR SURFACE COLOR: brownish-yellow

EXTERIOR SURFACE COLOR: brownishyellow; fire clouds on the neck and body

WALL THICKNESS (RIM, BODY, AND BASE

IN MM): rim, $6.9 \mathrm{~mm}$

INTERIOR SURFACE TREATMENT: none

EXTERIOR SURFACE TREATMENT: smoothed on the neck

HEIGHT (IN CM): 16.8

ORIFICE DIAMETER (IN CM): 4.0

DIAMETER AT BOTTOM OF RIM OR NECK (IN CM): $5.4 ; 10.8 \mathrm{~cm}$ at the widest point on the body

\section{BASE DIAMETER (IN CM) AND SHAPE OF}

BASE: 8.0; circular and flat

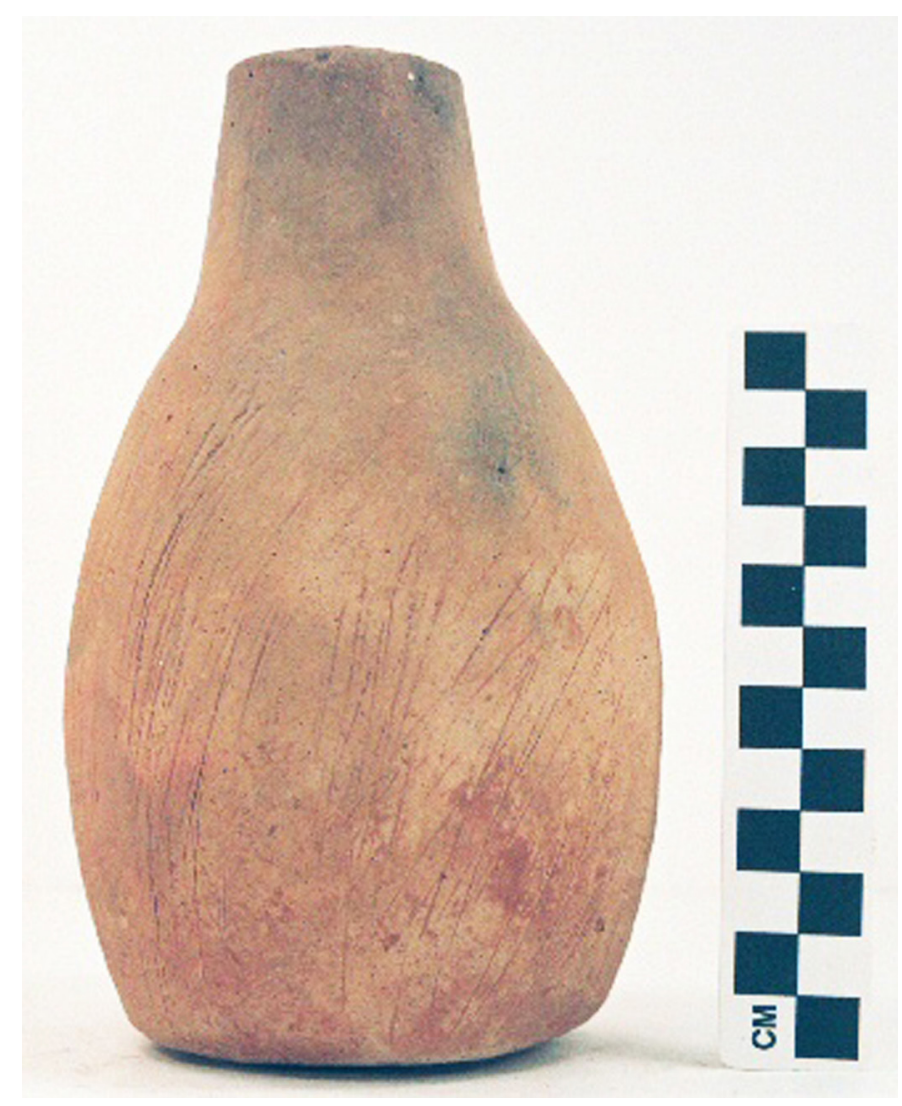

Figure 109. Hume Engraved, var. unspecified bottle from the Jim P. Allen site.

ESTIMATED VOLUME (IN LITERS): 0.5

DECORATION (INCLUDING MOTIF AND ELEMENTS WHEN APPARENT): The bottle neck has a single horizontal engraved line at the base of the neck, as well as a series of vertical engraved lines around the neck (Figure 109). The vessel body has vertical brushing marks.

PIGMENT USE AND LOCATION ON VESSEL: none

TYPE AND VARIETY [IF KNOWN]: Hume Engraved, var. unspecified 
SITE NAME OR SITE NUMBER: Jim P. Allen

VESSEL NO.: 41CE12-168; Burial AH-13

NON-PLASTICS AND PASTE: grog and hematite

VESSEL FORM: Bottle with a cylindrical body and a short neck

RIM AND LIP FORM: Direct rim and rounded lip

CORE COLOR: A (fired and cooled in an oxidizing environment)

INTERIOR SURFACE COLOR: light yellowishbrown

EXTERIOR SURFACE COLOR: light yellowishbrown

WALL THICKNESS (RIM, BODY, AND BASE IN MM): rim, $5.5 \mathrm{~mm}$

INTERIOR SURFACE TREATMENT: none

EXTERIOR SURFACE TREATMENT: smoothed on the rim and body

HEIGHT (IN CM): 27.9

ORIFICE DIAMETER (IN CM): 4.0

DIAMETER AT BOTTOM OF RIM OR NECK (IN CM): $5.1 ; 16.8 \mathrm{~cm}$ at the widest point on the body

BASE DIAMETER (IN CM) AND SHAPE OF BASE: 9.4; circular and flat

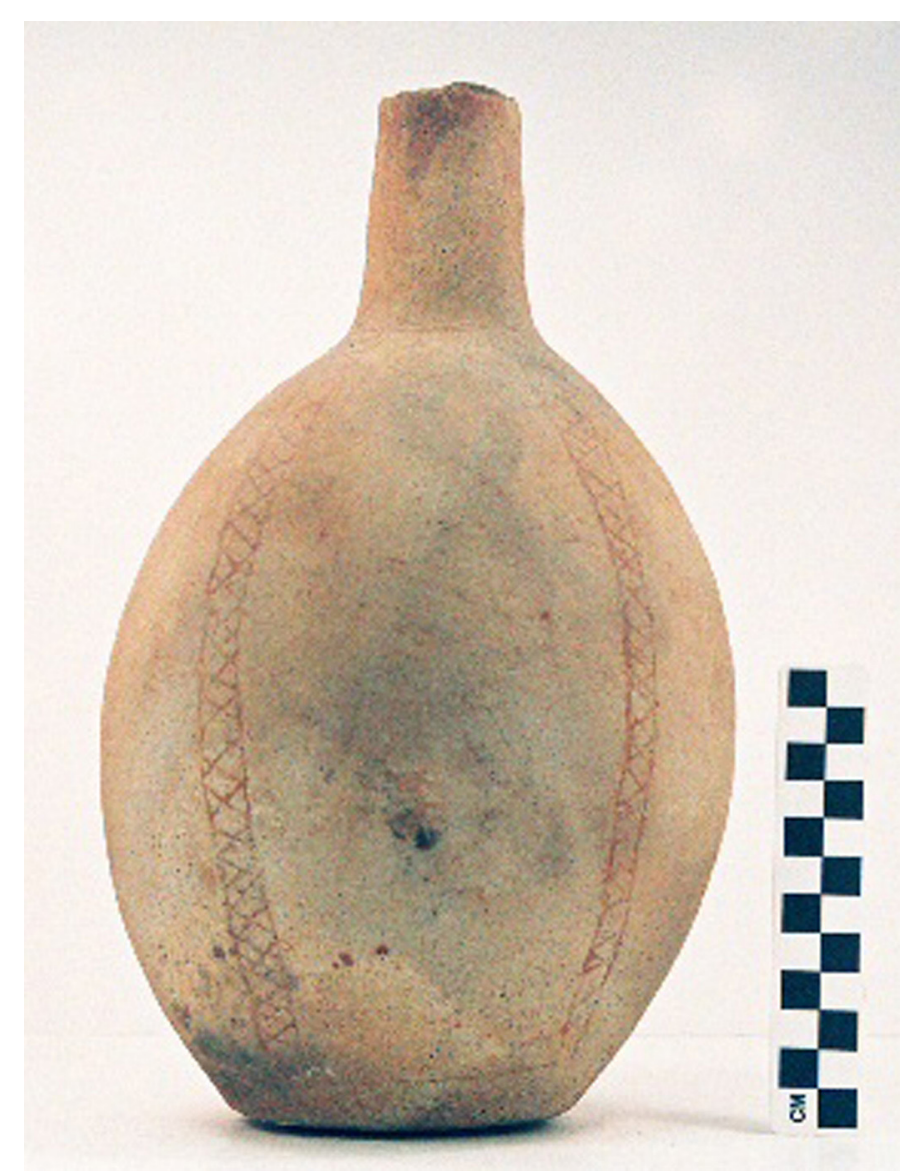

Figure 110. Hume Engraved, var. Hume bottle from the Jim P. Allen site.

ESTIMATED VOLUME (IN LITERS): 1.1

DECORATION (INCLUDING MOTIF AND ELEMENTS WHEN APPARENT): There are single horizontal engraved lines at the top of the bottle body and near the vessel base. Between these lines are four narrow engraved zones/bands filled with cross-hatched engraved lines (Figure 110).

PIGMENT USE AND LOCATION ON VESSEL: none

TYPE AND VARIETY [IF KNOWN]: Hume Engraved, var. Hume 
SITE NAME OR SITE NUMBER: Jim P. Allen

VESSEL NO.: 41CE12-169; Burial AH-13

NON-PLASTICS AND PASTE: grog and hematite

VESSEL FORM: Effigy bowl with opposed effigy head and tail rider (Figure 111a-b)

RIM AND LIP FORM: Direct rim and rounded lip

CORE COLOR: A (fired and cooled in an

oxidizing environment)

INTERIOR SURFACE COLOR: pinkish-gray

EXTERIOR SURFACE COLOR: light brown; fire clouds on the base

WALL THICKNESS (RIM, BODY, AND BASE

IN MM): $\operatorname{rim}, 5.7 \mathrm{~mm}$

INTERIOR SURFACE TREATMENT: smoothed

EXTERIOR SURFACE TREATMENT: smoothed

HEIGHT (IN CM): 9.7; $13.6 \mathrm{~cm}$ atop the effigy head

ORIFICE DIAMETER (IN CM): 14.6

DIAMETER AT BOTTOM OF RIM OR NECK (IN CM): N/A

BASE DIAMETER (IN CM) AND SHAPE OF BASE: 7.7; circular and flat
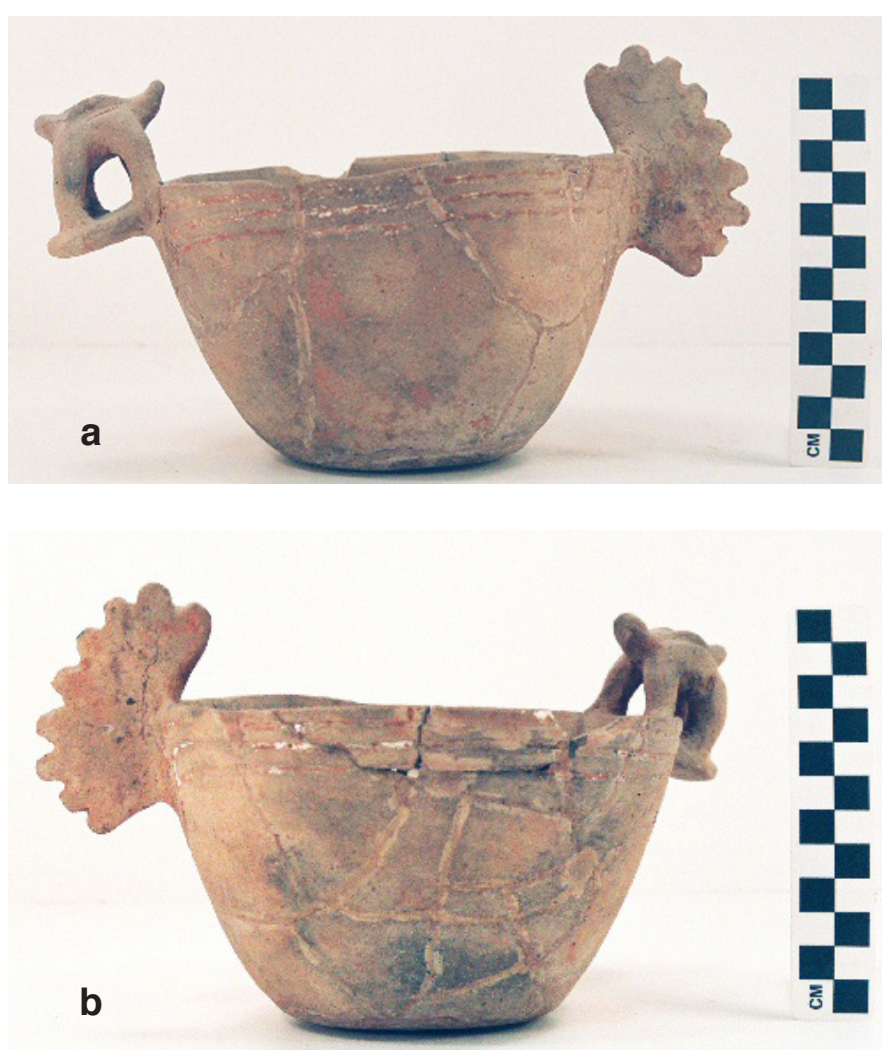

Figure 111. Hood Engraved, var. Allen effigy bowl from the Jim P. Allen site: a, side view; b, view showing the tail rider in more detail.

ESTIMATED VOLUME (IN LITERS): 0.6

DECORATION (INCLUDING MOTIF AND ELEMENTS WHEN APPARENT): the rim has three horizontal engraved lines around the vessel; the horizontal engraved lines dip under the effigy head and tail rider (Figure 111a). The effigy head resembles a coxcomb in profile, while the tail rider has its head facing inwards towards the back of the effigy head (Figure 111b). The tail rider resembles a loggerhead turtle with its flat head, small tail, and three appliqued ridges on its back.

PIGMENT USE AND LOCATION ON VESSEL: white pigment in engraved lines

TYPE AND VARIETY [IF KNOWN]: Hood Engraved, var. Allen 
SITE NAME OR SITE NUMBER: Jim P. Allen

VESSEL NO.: 41CE12-171; Burial AH-13

NON-PLASTICS AND PASTE: grog

VESSEL FORM: Globular Bowl

RIM AND LIP FORM: Everted rim and rounded lip

CORE COLOR: B (fired and cooled in a reducing environment)

INTERIOR SURFACE COLOR: very dark gray

EXTERIOR SURFACE COLOR: very dark gray

WALL THICKNESS (RIM, BODY, AND BASE

IN MM): rim, $4.0 \mathrm{~mm}$

INTERIOR SURFACE TREATMENT: smoothed on the rim and upper body

EXTERIOR SURFACE TREATMENT: smoothed on the rim and body

HEIGHT (IN CM): 7.3

ORIFICE DIAMETER (IN CM): 6.4

DIAMETER AT BOTTOM OF RIM OR NECK (IN CM): 6.4

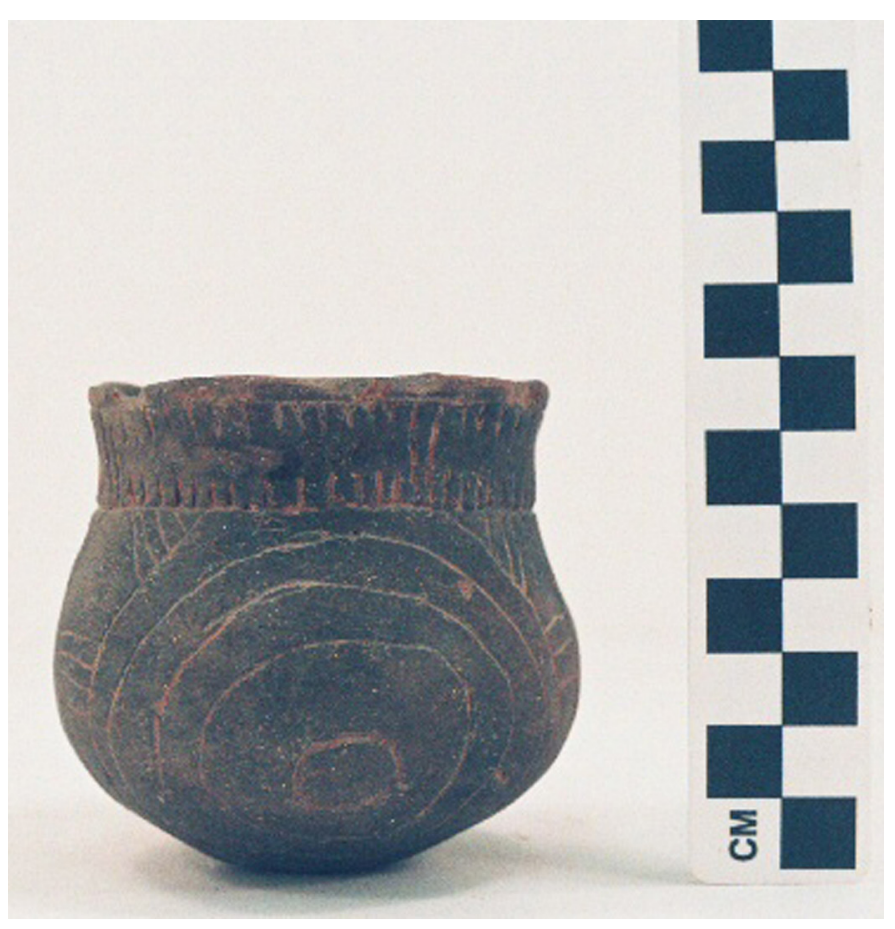

Figure 112. cf. Poynor Engraved, var. Freeman globular bowl from the Jim P. Allen site.

BASE DIAMETER (IN CM) AND SHAPE OF BASE: 2.4; circular and flat

ESTIMATED VOLUME (IN LITERS): 0.4

DECORATION (INCLUDING MOTIF AND ELEMENTS WHEN APPARENT): The rim panel is defined by single upper and lower horizontal engraved lines with either downward- or upward-pointing excised tick marks. The panel is divided into four sections by sets of two closely-spaced vertical engraved lines (Figure 112). The vessel body has three sets of engraved concentric circles, each set connected to the other by sets of three short horizontal engraved lines. Dividing the sets of concentric circles are three sets of hatched triangles pendant from the base of the rim (Figure 112).

PIGMENT USE AND LOCATION ON VESSEL: red pigment in engraved lines on the vessel body TYPE AND VARIETY [IF KNOWN]: cf. Poynor Engraved, var. Freeman 
SITE NAME OR SITE NUMBER: Jim P. Allen

VESSEL NO.: 41CE12-172; Burial AH-13

NON-PLASTICS AND PASTE: grog and hematite

VESSEL FORM: Globular Bowl

RIM AND LIP FORM: Direct rim and rounded lip

CORE COLOR: A (fired and cooled in an oxidizing environment)

INTERIOR SURFACE COLOR: light gray

EXTERIOR SURFACE COLOR: light gray; fire clouds on the rim, body, and base

WALL THICKNESS (RIM, BODY, AND BASE IN MM): rim, $4.6 \mathrm{~mm}$

INTERIOR SURFACE TREATMENT: smoothed on the rim

EXTERIOR SURFACE TREATMENT: smoothed on the rim

HEIGHT (IN CM): 8.5

ORIFICE DIAMETER (IN CM): 9.4

DIAMETER AT BOTTOM OF RIM OR NECK (IN CM): 9.7

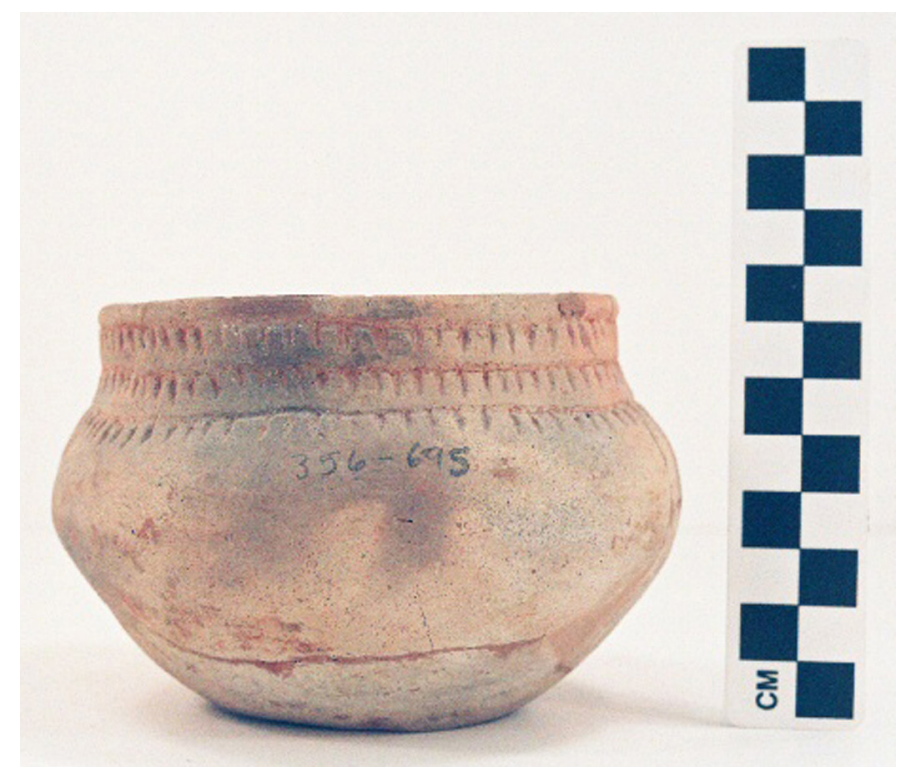

Figure 113. Patton Engraved, var. Allen globular bowl from the Jim P. Allen site.

BASE DIAMETER (IN CM) AND SHAPE OF BASE: 5.7; circular and flat

ESTIMATED VOLUME (IN LITERS): 0.6

DECORATION (INCLUDING MOTIF AND ELEMENTS WHEN APPARENT): The rim has three horizontal engraved lines with downward-pointing linear tick marks (Figure 113).

PIGMENT USE AND LOCATION ON VESSEL: none

TYPE AND VARIETY [IF KNOWN]: Patton Engraved, var. Allen 
SITE NAME OR SITE NUMBER: Jim P. Allen

VESSEL NO.: 41CE12-173; Burial AH-13

NON-PLASTICS AND PASTE: grog and hematite; fine sandy paste

VESSEL FORM: Carinated Bowl

RIM AND LIP FORM: Inverted rim and rounded lip

CORE COLOR: A (fired and cooled in an oxidizing environment)

INTERIOR SURFACE COLOR: dark yellowish-brown

EXTERIOR SURFACE COLOR: brown; fire clouds on the rim and body

WALL THICKNESS (RIM, BODY, AND BASE

IN MM): rim, $6.9 \mathrm{~mm}$

INTERIOR SURFACE TREATMENT: smoothed on the rim

EXTERIOR SURFACE TREATMENT: smoothed on the rim

HEIGHT (IN CM): 17.9

ORIFICE DIAMETER (IN CM): 27.1

DIAMETER AT BOTTOM OF RIM OR NECK (IN CM): 28.0

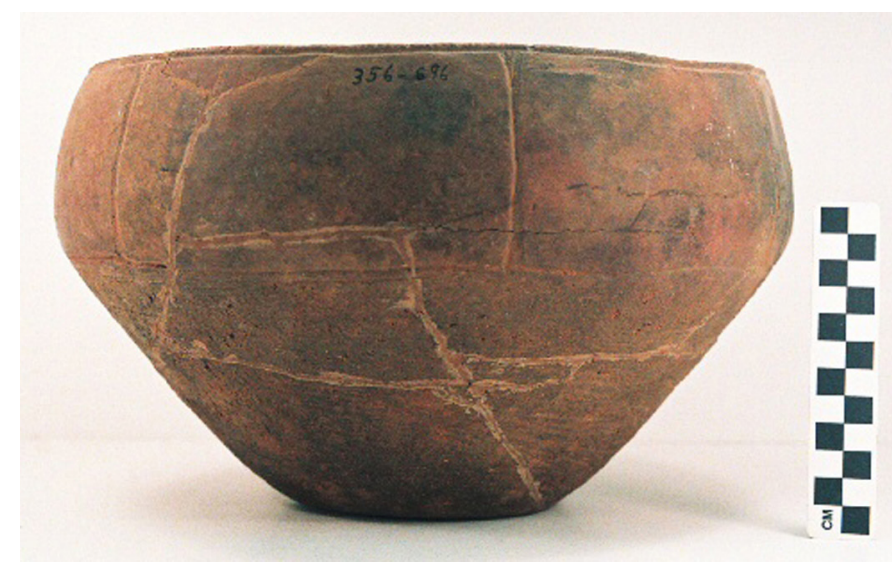

Figure 114. Poynor Engraved, var. Blackburn carinated bowl from the Jim P. Allen site.

BASE DIAMETER (IN CM) AND SHAPE OF BASE: 10.2; circular and flat

ESTIMATED VOLUME (IN LITERS): 4.4

DECORATION (INCLUDING MOTIF AND ELEMENTS WHEN APPARENT): The vessel lip is lip notched. The rim panel has single upper and lower horizontal engraved lines. The panel is divided into seven sections by a series of vertical excised lines (Figure 114). The vessel body has horizontal brushing marks.

PIGMENT USE AND LOCATION ON VESSEL: none

TYPE AND VARIETY [IF KNOWN]: Poynor Engraved, var. Blackburn 
SITE NAME OR SITE NUMBER: Jim P. Allen

VESSEL NO.: 41CE12-174; Burial AH-14

NON-PLASTICS AND PASTE: grog

VESSEL FORM: Jar

RIM AND LIP FORM: N/A

CORE COLOR: K (incompletely oxidized during firing, with sooting/smudging on inner vessel surface)

INTERIOR SURFACE COLOR: very dark gray

EXTERIOR SURFACE COLOR: light brown; fire clouds on the body and base

WALL THICKNESS (RIM, BODY, AND BASE

IN MM): body, $7.4 \mathrm{~mm}$

INTERIOR SURFACE TREATMENT: smoothed

EXTERIOR SURFACE TREATMENT: smoothed on the lower body

HEIGHT (IN CM): N/A

ORIFICE DIAMETER (IN CM): 17.6

DIAMETER AT BOTTOM OF RIM OR NECK (IN CM): N/A

BASE DIAMETER (IN CM) AND SHAPE OF

BASE: 9.0; circular and flat

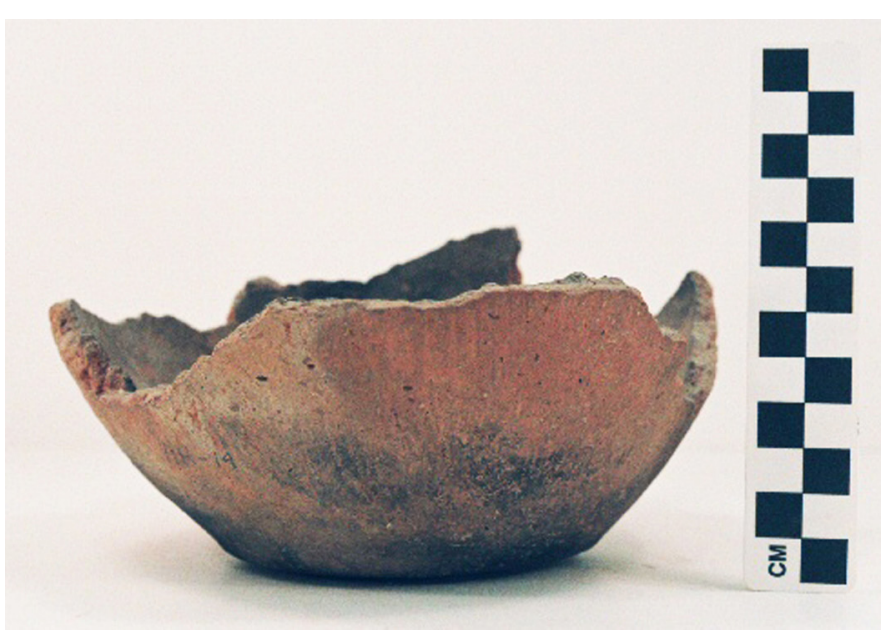

Figure 115. Bullard Brushed jar section from the Jim P. Allen site.

ESTIMATED VOLUME (IN LITERS): N/A

DECORATION (INCLUDING MOTIF AND ELEMENTS WHEN APPARENT): The vessel body has vertical brushing marks that extend to within $2.2 \mathrm{~cm}$ of the vessel base (Figure 115).

PIGMENT USE AND LOCATION ON VESSEL: none

TYPE AND VARIETY [IF KNOWN]: Bullard Brushed 
SITE NAME OR SITE NUMBER: Jim P. Allen

VESSEL NO.: 41CE12-175; Burial AH-14

NON-PLASTICS AND PASTE: bone and hematite

VESSEL FORM: Globular Bowl

RIM AND LIP FORM: Direct rim and rounded lip

CORE COLOR: A (fired and cooled in an oxidizing environment)

INTERIOR SURFACE COLOR: reddish-brown

EXTERIOR SURFACE COLOR: reddish-brown; fire clouds on the rim, body, and base

WALL THICKNESS (RIM, BODY, AND BASE IN MM): rim, 4.9 mm

INTERIOR SURFACE TREATMENT: smoothed on the rim and body

EXTERIOR SURFACE TREATMENT: burnished on the rim and smoothed on the body

HEIGHT (IN CM): 13.3

ORIFICE DIAMETER (IN CM): 12.6

DIAMETER AT BOTTOM OF RIM OR NECK (IN CM): 13.2

BASE DIAMETER (IN CM) AND SHAPE OF

BASE: 8.0; circular and flat

ESTIMATED VOLUME (IN LITERS): 1.5

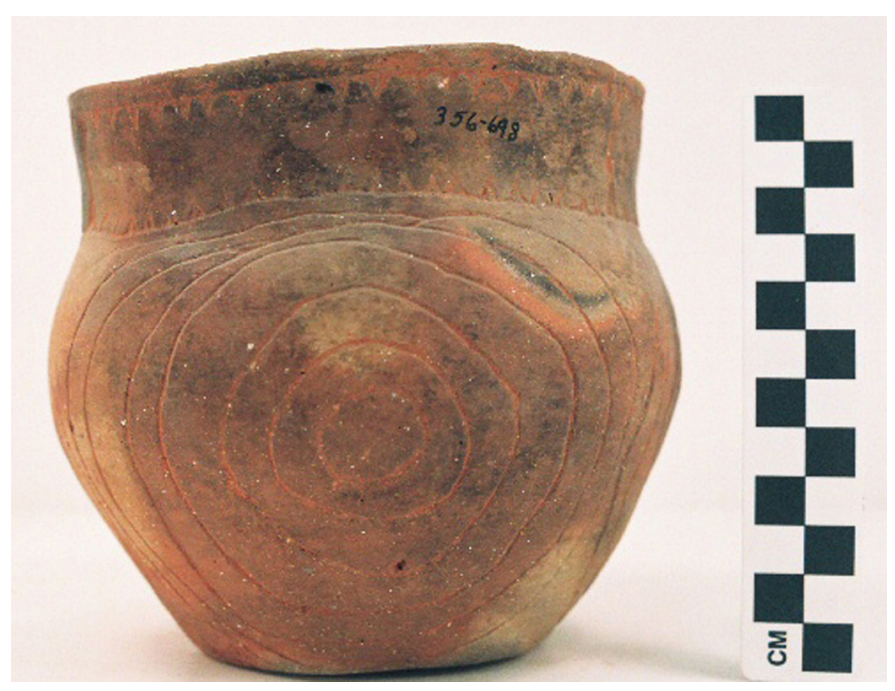

Figure 116. Poynor Engraved, var. Freeman globular bowl from the Jim P. Allen site.

DECORATION (INCLUDING MOTIF AND ELEMENTS WHEN APPARENT): The rim panel is defined by single upper and lower horizontal engraved lines with either downward- or upward-pointing excised tick marks. The panel is divided into three sections by excised brackets (Figure 116). The vessel body has three sets of engraved concentric circles, divided by large upper and lower pendant triangles. These pendant triangles have hatched lines or smaller triangular elements within them.

PIGMENT USE AND LOCATION ON VESSEL: none

TYPE AND VARIETY [IF KNOWN]: Poynor Engraved, var. Freeman 
SITE NAME OR SITE NUMBER: Jim P. Allen

VESSEL NO.: 41CE12-176; Burial AH-14

NON-PLASTICS AND PASTE: grog and hematite

VESSEL FORM: Effigy bowl with opposed attachments (effigy head-missing — and a tail rider) (Figure 117)

RIM AND LIP FORM: Direct rim and rounded lip

CORE COLOR: A (fired and cooled in an oxidizing environment)

INTERIOR SURFACE COLOR: reddish-yellow

EXTERIOR SURFACE COLOR: reddish-yellow; fire clouds on the rim and body

WALL THICKNESS (RIM, BODY, AND BASE IN

MM): rim, $5.1 \mathrm{~mm}$

INTERIOR SURFACE TREATMENT: none

EXTERIOR SURFACE TREATMENT: none

HEIGHT (IN CM): $5.6 ; 7.6 \mathrm{~cm}$ in height atop the tail rider

ORIFICE DIAMETER (IN CM): 7.9

DIAMETER AT BOTTOM OF RIM OR NECK (IN CM): N/A

BASE DIAMETER (IN CM) AND SHAPE OF

BASE: 5.0; circular and flat

ESTIMATED VOLUME (IN LITERS): 0.2

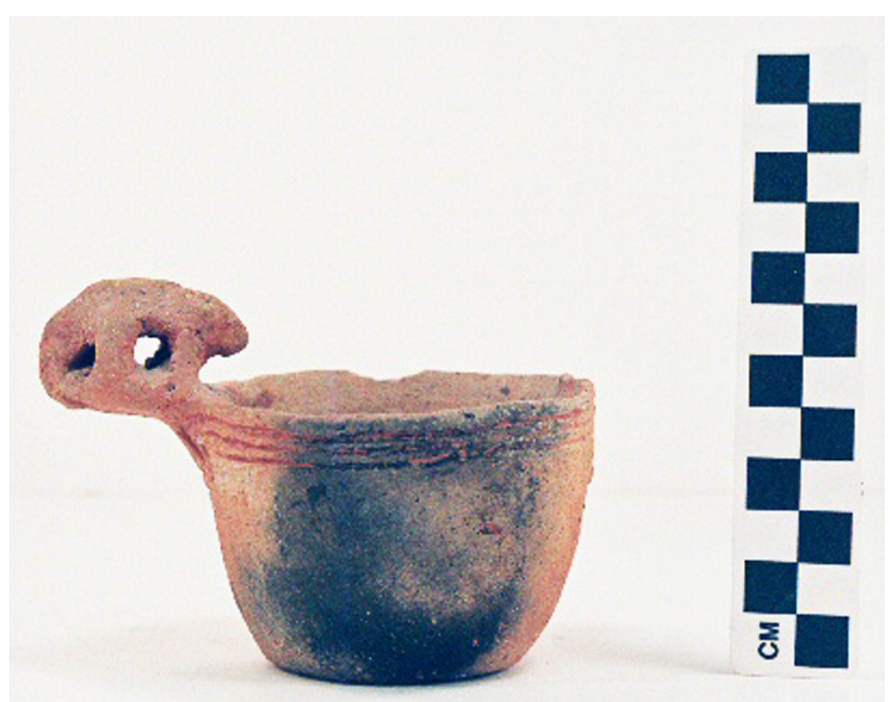

Figure 117. Hood Engraved, var. Allen effigy bowl from the Jim P. Allen site.

DECORATION (INCLUDING MOTIF AND ELEMENTS WHEN APPARENT): The rim has three horizontal engraved lines that dip underneath the effigy head and tail rider attachments (Figure 117). The effigy head is missing, although its attachment area is apparent, and the tail rider is a quadruped facing inwards towards the effigy head. The tail rider has two ears, two small dots for eyes, and a tail.

PIGMENT USE AND LOCATION ON VESSEL: red clay pigment in engraved lines TYPE AND VARIETY [IF KNOWN]: Hood Engraved, var. Allen 
SITE NAME OR SITE NUMBER: Jim P. Allen

VESSEL NO.: 41CE12-178; Burial AH-15

NON-PLASTICS AND PASTE: grog and hematite

VESSEL FORM: Carinated bowl

RIM AND LIP FORM: Inverted rim and rounded lip

CORE COLOR: A (fired and cooled in an oxidizing environment)

INTERIOR SURFACE COLOR: light brown

EXTERIOR SURFACE COLOR: pinkish-gray;

fire clouds on the base

WALL THICKNESS (RIM, BODY, AND BASE

IN MM): rim, $5.4 \mathrm{~mm}$

INTERIOR SURFACE TREATMENT: none

EXTERIOR SURFACE TREATMENT: none

HEIGHT (IN CM): 4.9

ORIFICE DIAMETER (IN CM): 8.6

DIAMETER AT BOTTOM OF RIM OR NECK

(IN CM): 9.6

BASE DIAMETER (IN CM) AND SHAPE OF

BASE: 4.4; circular and flat

ESTIMATED VOLUME (IN LITERS): 0.3

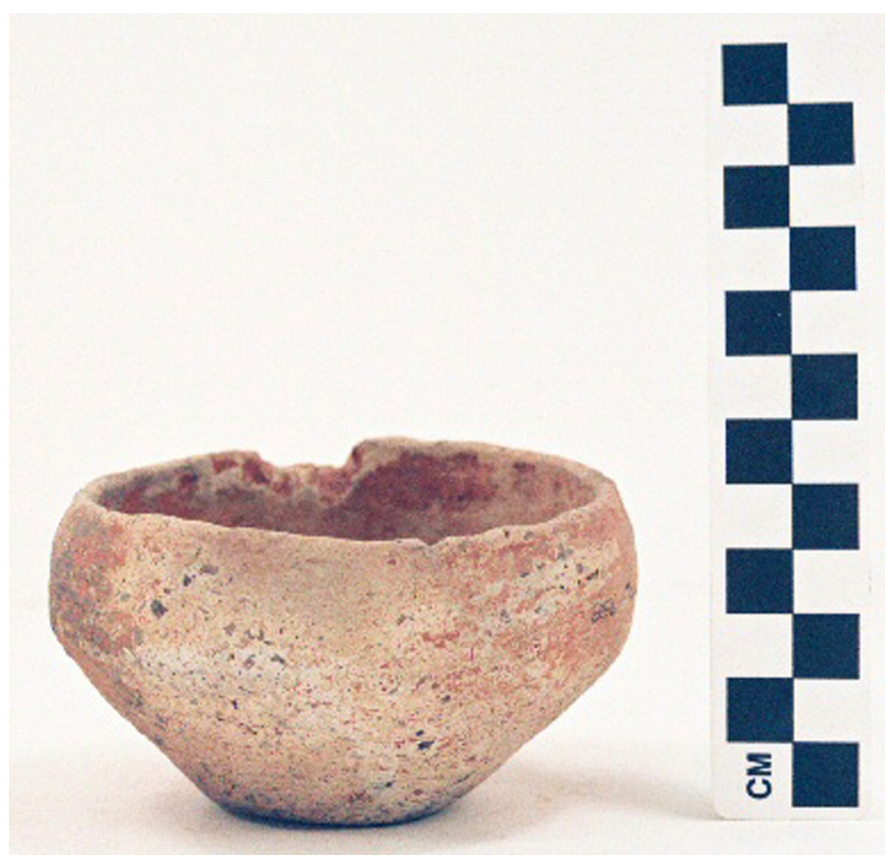

Figure 118. Brushed carinated bowl from the Jim P. Allen site.

DECORATION (INCLUDING MOTIF AND ELEMENTS WHEN APPARENT): The rim of the vessel is plain, and the body has faint horizontal brushing marks (Figure 118).

PIGMENT USE AND LOCATION ON VESSEL: none

TYPE AND VARIETY [IF KNOWN]: Unidentified utility ware 
SITE NAME OR SITE NUMBER: Jim P. Allen

VESSEL NO.: 41CE12-179; Burial AH-15

NON-PLASTICS AND PASTE: grog

VESSEL FORM: Globular Bowl

RIM AND LIP FORM: Direct rim and rounded lip

CORE COLOR: A (fired and cooled in an oxidizing environment)

INTERIOR SURFACE COLOR: brown

EXTERIOR SURFACE COLOR: brown; fire clouds on the rim and body

WALL THICKNESS (RIM, BODY, AND BASE

IN MM): rim, $6.3 \mathrm{~mm}$

INTERIOR SURFACE TREATMENT: smoothed on the rim and body

EXTERIOR SURFACE TREATMENT: smoothed on the rim and body

HEIGHT (IN CM): 6.8

ORIFICE DIAMETER (IN CM): 8.5

DIAMETER AT BOTTOM OF RIM OR NECK (IN CM): 8.9

BASE DIAMETER (IN CM) AND SHAPE OF BASE: 3.9 ; circular and flat

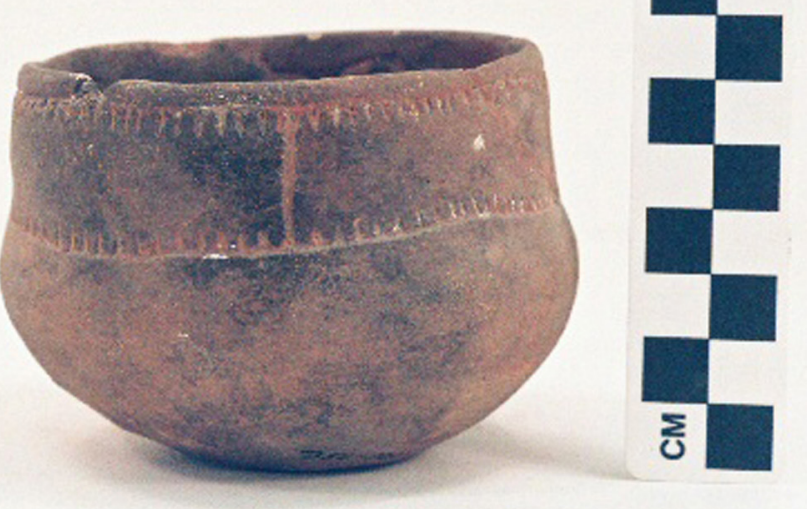

Figure 119. Poynor Engraved, var. Freeman globular bowl from the Jim P. Allen site.

ESTIMATED VOLUME (IN LITERS): 0.4

DECORATION (INCLUDING MOTIF AND ELEMENTS WHEN APPARENT): The rim panel is defined by single upper and lower horizontal engraved lines with either downward- or upward-pointing excised tick marks. The panel is divided into five rectangular sections by five equally-spaced vertical engraved lines (Figure 119).

PIGMENT USE AND LOCATION ON VESSEL: white pigment in the engraved lines TYPE AND VARIETY [IF KNOWN]: Poynor Engraved, var. Freeman 
SITE NAME OR SITE NUMBER: Jim P. Allen

VESSEL NO.: 41CE12-180; Burial AH-15

NON-PLASTICS AND PASTE: grog and hematite

VESSEL FORM: Globular bowl

RIM AND LIP FORM: Direct rim and rounded lip

CORE COLOR: A (fired and cooled in an oxidizing environment)

INTERIOR SURFACE COLOR: brown

EXTERIOR SURFACE COLOR: brown; fire clouds on the body

WALL THICKNESS (RIM, BODY, AND BASE IN MM): rim, $5.2 \mathrm{~mm}$

INTERIOR SURFACE TREATMENT: smoothed on the rim and the upper body

EXTERIOR SURFACE TREATMENT: smoothed on the rim

HEIGHT (IN CM): 10.8

ORIFICE DIAMETER (IN CM): 9.8

DIAMETER AT BOTTOM OF RIM OR NECK (IN CM): 9.5

BASE DIAMETER (IN CM) AND SHAPE OF

BASE: 6.6; circular and flat

ESTIMATED VOLUME (IN LITERS): 0.8

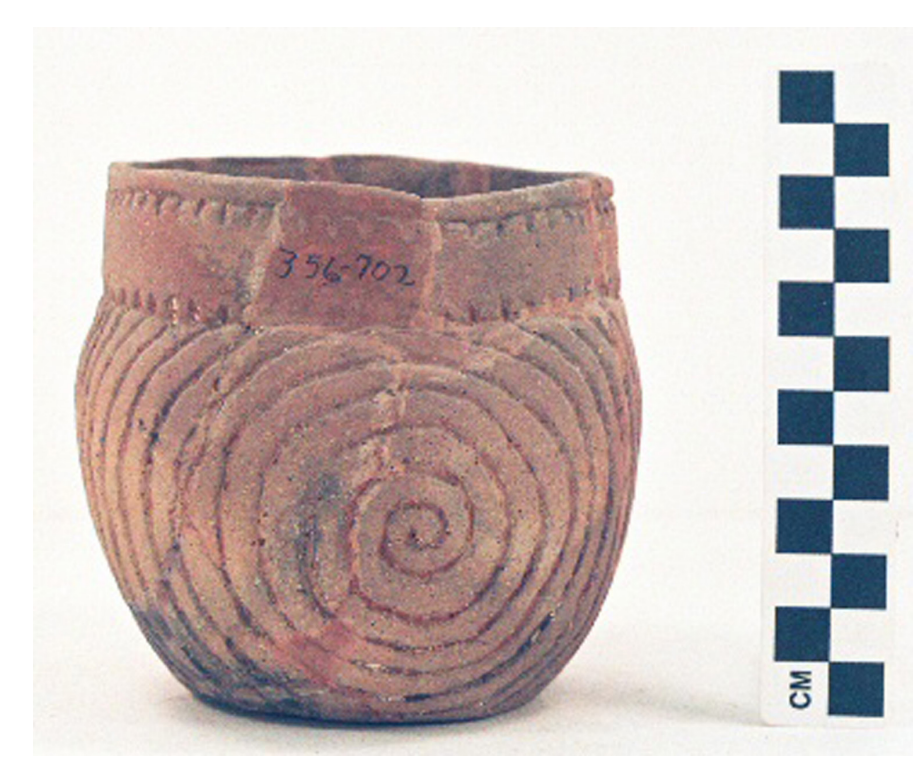

Figure 120. Poynor Engraved, var. Freeman globular bowl from the Jim P. Allen site.

DECORATION (INCLUDING MOTIF AND ELEMENTS WHEN APPARENT): The rim panel is defined by single upper and lower horizontal engraved lines with either downward- or upward-pointing excised tick marks. The panel is divided into seven rectangular sections by equally-spaced vertical engraved lines (Figure 120). The vessel body has two sets of engraved concentric spirals. These are divided at their upper ends by large upper and lower engraved pendant triangles; each of these pendant triangles have two smaller triangular elements within them (Figure 120).

PIGMENT USE AND LOCATION ON VESSEL: white pigment in the engraved lines

TYPE AND VARIETY [IF KNOWN]: Poynor Engraved, var. Freeman 
SITE NAME OR SITE NUMBER: Jim P. Allen

VESSEL NO.: 41CE12-181; Burial AH-16

NON-PLASTICS AND PASTE: grog and hematite

VESSEL FORM: Effigy bowl with opposed effigy head and tail rider

RIM AND LIP FORM: Direct rim and rounded lip

CORE COLOR: A (fired and cooled in an oxidizing environment); pinkware

INTERIOR SURFACE COLOR: brown

EXTERIOR SURFACE COLOR: yellowish-red; fire clouds on the rim and body

WALL THICKNESS (RIM, BODY, AND BASE IN MM): rim, $6.4 \mathrm{~mm}$

INTERIOR SURFACE TREATMENT: smoothed EXTERIOR SURFACE TREATMENT: smoothed HEIGHT (IN CM): 10.6; $14.0 \mathrm{~cm}$ atop the effigy head

ORIFICE DIAMETER (IN CM): 16.6

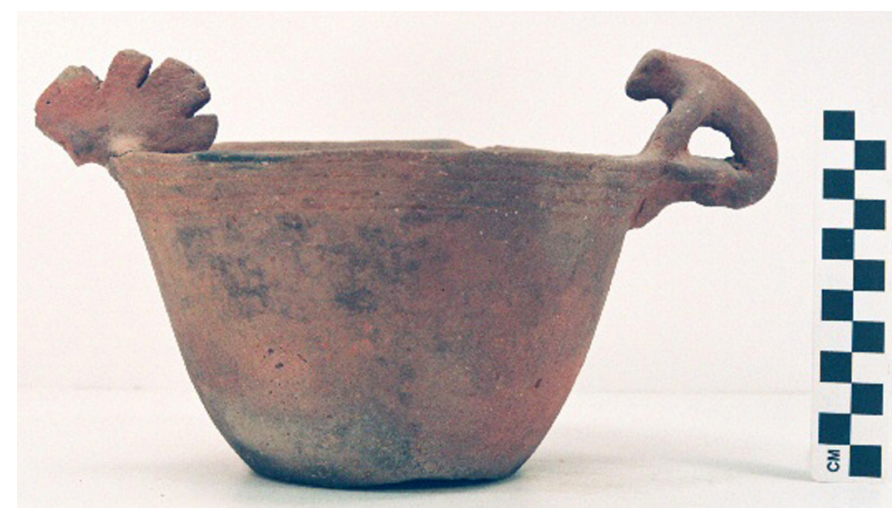

Figure 121. Hood Engraved, var. Allen effigy bowl from the Jim P. Allen site.

DIAMETER AT BOTTOM OF RIM OR NECK (IN CM): N/A

BASE DIAMETER (IN CM) AND SHAPE OF BASE: 9.2; circular and flat

ESTIMATED VOLUME (IN LITERS): 0.7

DECORATION (INCLUDING MOTIF AND ELEMENTS WHEN APPARENT): The rim has four horizontal engraved lines (Figure 121); these dip down under the attachments for the effigy head and are discontinuous at the tail rider attachment. The effigy head resembles a coxcomb in profile, and this was formed by three deep vertical notches. The tail rider faces inward towards the effigy head, and is a quadruped with two dots for eyes, two small ears, and front and back legs attached to the vessel rim (Figure 121).

PIGMENT USE AND LOCATION ON VESSEL: none

TYPE AND VARIETY [IF KNOWN]: Hood Engraved, var. Allen 
SITE NAME OR SITE NUMBER: Jim P. Allen

VESSEL NO.: 41CE12-182; Burial AH-16

NON-PLASTICS AND PASTE: grog

VESSEL FORM: Carinated bowl with a narrow rim panel; hubcap-style form

RIM AND LIP FORM: Inverted rim and rounded lip

CORE COLOR: G (fired in a reducing environment and cooled in the open air)

INTERIOR SURFACE COLOR: black

EXTERIOR SURFACE COLOR: brown; fire clouds on the lower body and base

WALL THICKNESS (RIM, BODY, AND BASE

IN MM): rim, $5.1 \mathrm{~mm}$

INTERIOR SURFACE TREATMENT: smoothed on the rim

EXTERIOR SURFACE TREATMENT: smoothed on the rim and body

HEIGHT (IN CM): 6.4

ORIFICE DIAMETER (IN CM): 11.5

DIAMETER AT BOTTOM OF RIM OR NECK (IN CM): 13.0

BASE DIAMETER (IN CM) AND SHAPE OF BASE: 6.4

ESTIMATED VOLUME (IN LITERS): 0.4

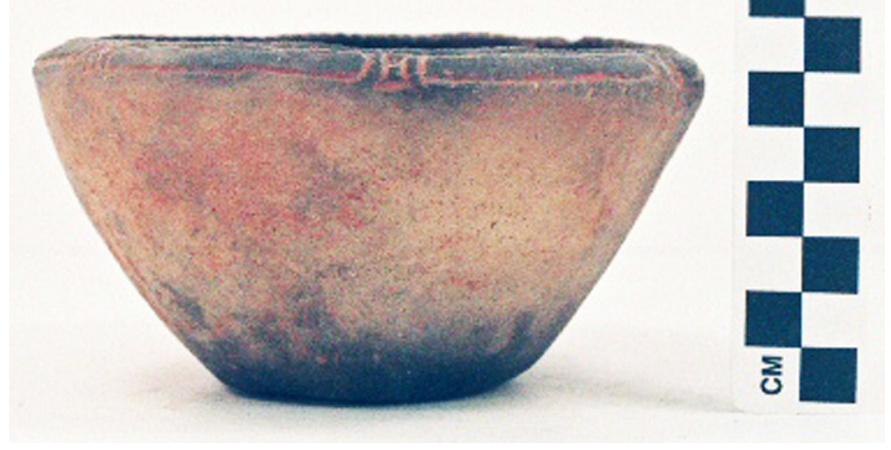

Figure 122. Simms Engraved carinated bowl from the Jim P. Allen site.

DECORATION (INCLUDING MOTIF AND ELEMENTS WHEN APPARENT): The lip has a regular series of lip notches. The rim panel is defined by single upper and lower horizontal engraved lines. The panel is divided into seven rectangular sections by engraved bracket-shaped elements (Figure 122). Six of the brackets have a single central horizontal engraved line in them, while two other brackets are open.

PIGMENT USE AND LOCATION ON VESSEL: red pigment in engraved

TYPE AND VARIETY [IF KNOWN]: Simms Engraved 
SITE NAME OR SITE NUMBER: Jim P. Allen

VESSEL NO.: 41CE12-183; Burial AH-16

NON-PLASTICS AND PASTE: grog and hematite; fine sandy paste; pinkware

VESSEL FORM: Jar

RIM AND LIP FORM: N/A

CORE COLOR: G (fired in a reducing environment and cooled in the open air)

INTERIOR SURFACE COLOR: very dark gray

EXTERIOR SURFACE COLOR: yellowish-red; fire clouds on the base

WALL THICKNESS (RIM, BODY, AND BASE IN MM): body, $7.0 \mathrm{~mm}$

INTERIOR SURFACE TREATMENT: none

EXTERIOR SURFACE TREATMENT: none

HEIGHT (IN CM): N/A

ORIFICE DIAMETER (IN CM): 12.3

DIAMETER AT BOTTOM OF RIM OR NECK (IN CM): N/A

BASE DIAMETER (IN CM) AND SHAPE OF BASE: 6.3; flat and circular

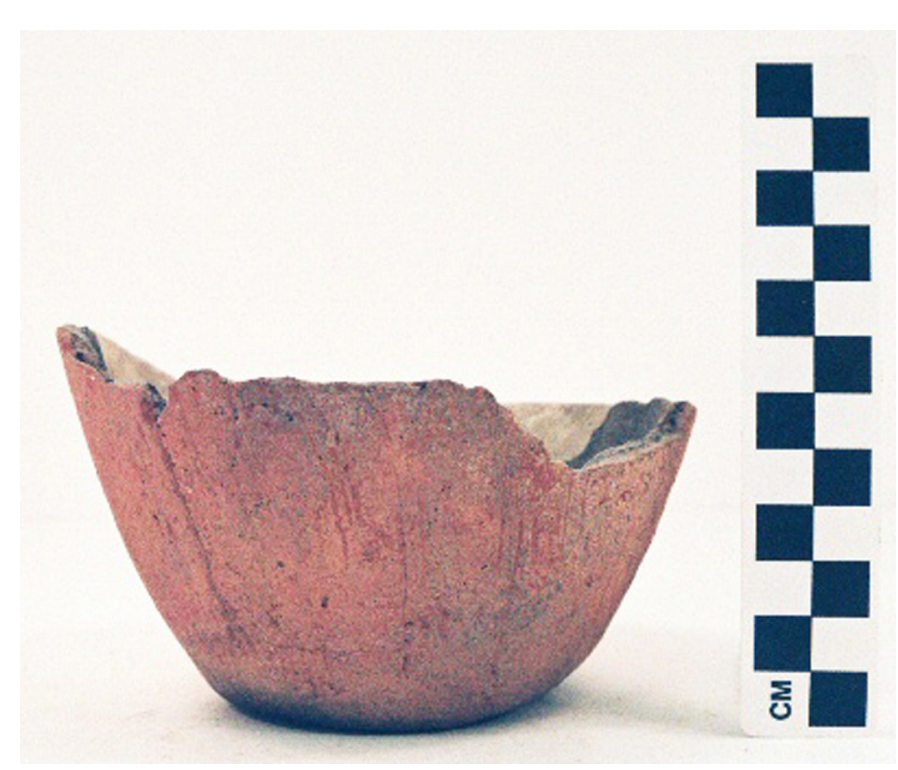

Figure 123. Bullard Brushed jar section from the Jim P. Allen site.

ESTIMATED VOLUME (IN LITERS): N/A

DECORATION (INCLUDING MOTIF AND ELEMENTS WHEN APPARENT): There are vertical brushing marks on the vessel body (Figure 123).

PIGMENT USE AND LOCATION ON VESSEL: none

TYPE AND VARIETY [IF KNOWN]: Bullard Brushed 
SITE NAME OR SITE NUMBER: Jim P. Allen

VESSEL NO.: 41CE12-184; Burial AH-16

NON-PLASTICS AND PASTE: grog and hematite

VESSEL FORM: Bottle with a short and narrow neck

RIM AND LIP FORM: Direct rim and flat lip

CORE COLOR: A (fired and cooled in an oxidizing environment)

INTERIOR SURFACE COLOR: brownish-yellow

EXTERIOR SURFACE COLOR: brownishyellow

WALL THICKNESS (RIM, BODY, AND BASE IN MM): rim, $8.0 \mathrm{~mm}$

INTERIOR SURFACE TREATMENT: none

EXTERIOR SURFACE TREATMENT: smoothed on the lower body

HEIGHT (IN CM): 23.8

ORIFICE DIAMETER (IN CM): 4.0

DIAMETER AT BOTTOM OF RIM OR NECK (IN CM): $4.8 ; 12.0 \mathrm{~cm}$ at its widest point on the body

BASE DIAMETER (IN CM) AND SHAPE OF BASE: 7.0; circular and flat

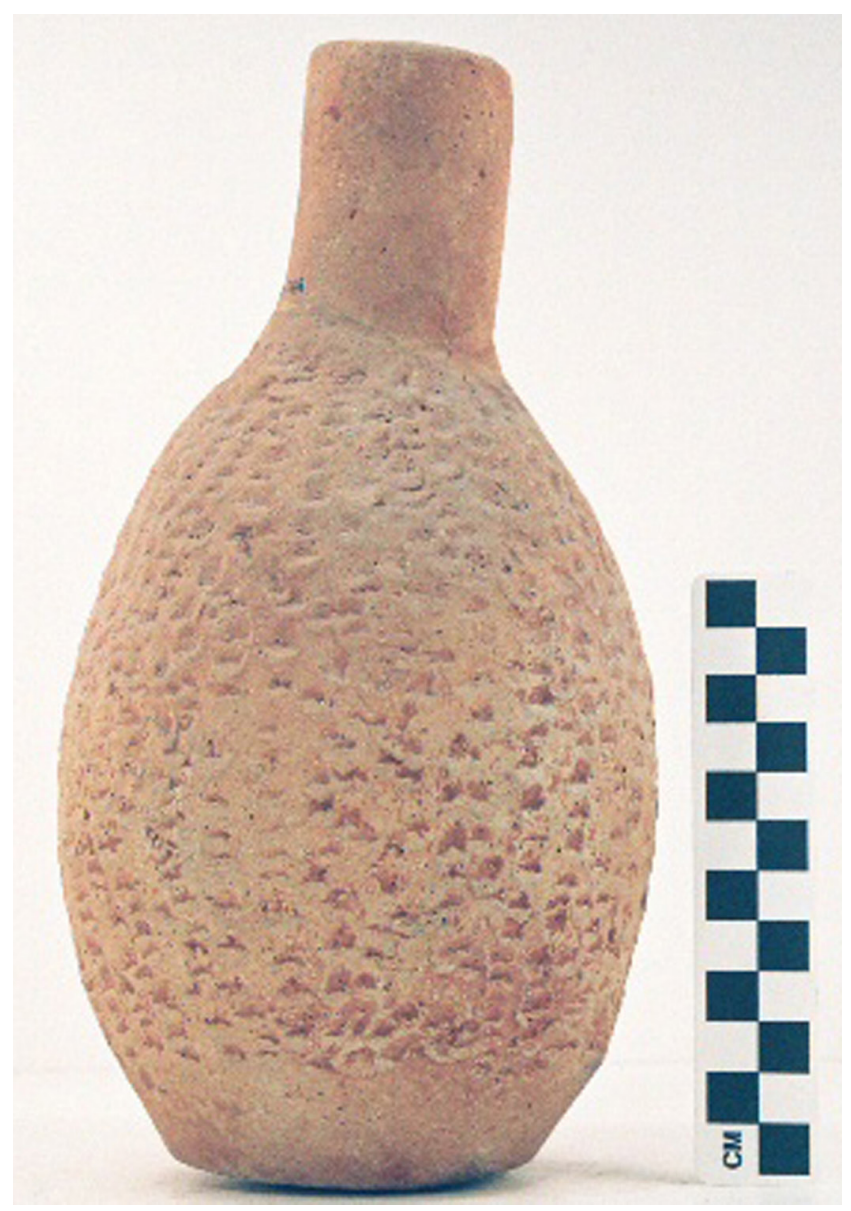

ESTIMATED VOLUME (IN LITERS): 0.7

Figure 124. Killough Pinched, var. Allen bottle from the Jim P. Allen site.

DECORATION (INCLUDING MOTIF AND ELEMENTS WHEN APPARENT): Vertical pinched rows cover the entirety of the vessel body, except for the bottom $20 \mathrm{~mm}$ above the vessel base (Figure 124).

PIGMENT USE AND LOCATION ON VESSEL: none

TYPE AND VARIETY [IF KNOWN]: Killough Pinched, var. Allen 
SITE NAME OR SITE NUMBER: Jim P. Allen

VESSEL NO.: 41CE12-185; Burial AH-16

NON-PLASTICS AND PASTE: bone and hematite

VESSEL FORM: Bottle with a short neck

RIM AND LIP FORM: Direct rim and flat lip

CORE COLOR: A (fired and cooled in an oxidizing environment)

INTERIOR SURFACE COLOR: reddish-yellow

EXTERIOR SURFACE COLOR: reddish-yellow; fire clouds on the neck and body

WALL THICKNESS (RIM, BODY, AND BASE IN MM): rim, $7.9 \mathrm{~mm}$

INTERIOR SURFACE TREATMENT: none

EXTERIOR SURFACE TREATMENT: none

HEIGHT (IN CM): 27.3

ORIFICE DIAMETER (IN CM): 5.2

DIAMETER AT BOTTOM OF RIM OR NECK (IN $\mathrm{CM}): 6.7 ; 14.2 \mathrm{~cm}$ at the widest part of the body

BASE DIAMETER (IN CM) AND SHAPE OF

BASE: 9.0 ; circular and flat

ESTIMATED VOLUME (IN LITERS): 1.0

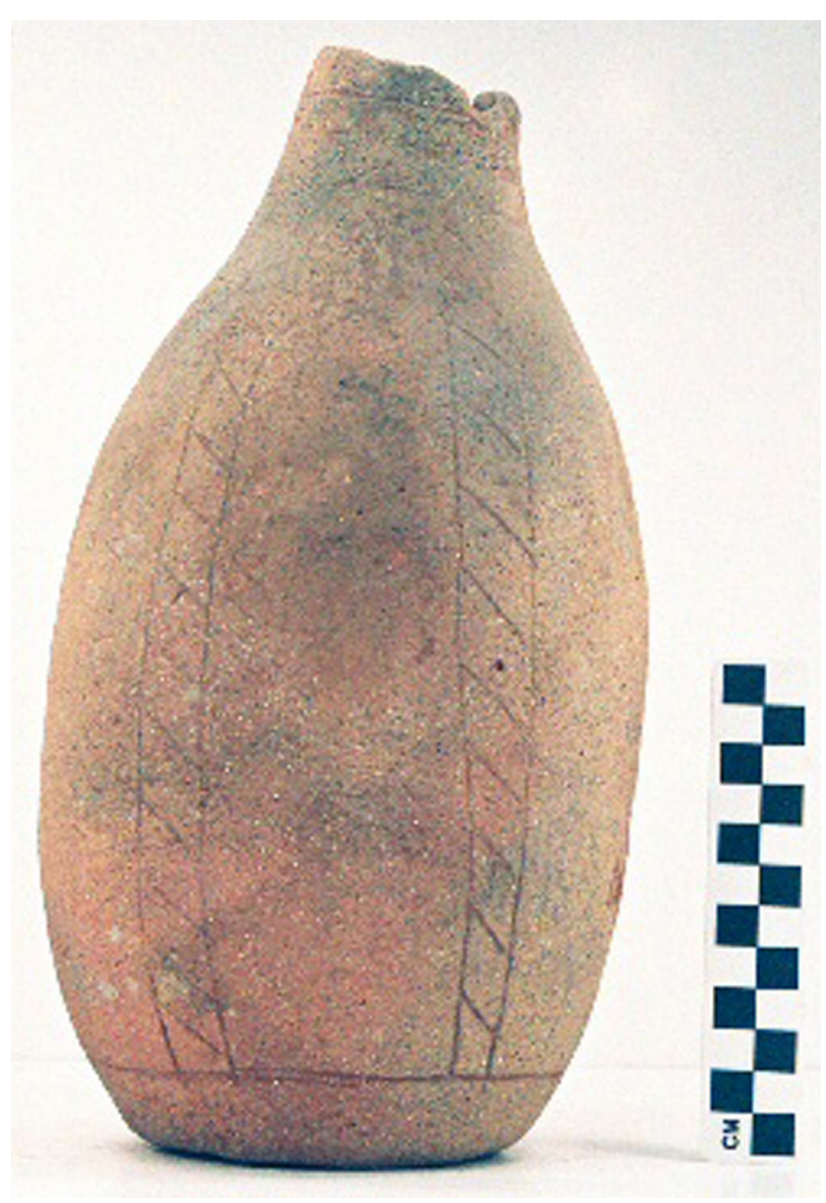

Figure 125. Hume Engraved, var. unspecified bottle from the Jim P. Allen site.

DECORATION (INCLUDING MOTIF AND ELEMENTS WHEN APPARENT): The bottle neck has four horizontal engraved lines. The vessel body has six narrow engraved zones or bands filled with diagonal hatched lines (Figure 125). These narrow zones or bands end at a single horizontal engraved line near the vessel base.

PIGMENT USE AND LOCATION ON VESSEL: none

TYPE AND VARIETY [IF KNOWN]: Hume Engraved, var. unspecified 
SITE NAME OR SITE NUMBER: Jim P. Allen

VESSEL NO.: 41CE12-186; Burial AH-16

NON-PLASTICS AND PASTE: grog and hematite

VESSEL FORM: Carinated Bowl

RIM AND LIP FORM: Direct rim and rounded lip

CORE COLOR: A (fired and cooled in an oxidizing environment)

INTERIOR SURFACE COLOR: dark yellowish-brown

EXTERIOR SURFACE COLOR: brown; fire clouds on the rim, body, and base

WALL THICKNESS (RIM, BODY, AND BASE IN MM): rim, $6.5 \mathrm{~mm}$

INTERIOR SURFACE TREATMENT: smoothed on the rim and body

EXTERIOR SURFACE TREATMENT: smoothed on the rim

HEIGHT (IN CM): 16.7

ORIFICE DIAMETER (IN CM): 29.0

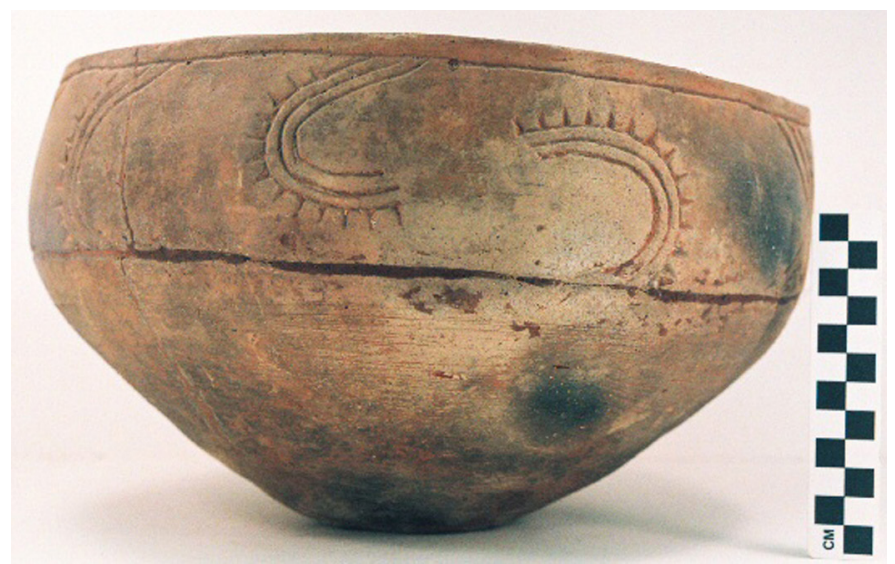

Figure 126. Patton Engraved, var. Patton carinated bowl from the Jim P. Allen site.

DIAMETER AT BOTTOM OF RIM OR NECK (IN CM): 29.1

BASE DIAMETER (IN CM) AND SHAPE OF BASE: 8.0; circular and flat

ESTIMATED VOLUME (IN LITERS): 4.4

DECORATION (INCLUDING MOTIF AND ELEMENTS WHEN APPARENT): The rim panel is defined by single upper and lower horizontal engraved lines. The panel is divided into two sections by opposed vertical curvilinear bracket elements. The sections each have two opposed hooked arm elements composed of three closely-spaced engraved lines; the outermost engraved lines have outward-pointing excised tick marks (Figure 126). Between the hooked arm elements and the brackets are two sets of three closely spaced vertical curvilinear engraved lines; the outermost engraved line has outward-pointing tick marks. The vessel body has horizontal and overlapping brushed marks.

PIGMENT USE AND LOCATION ON VESSEL: none

TYPE AND VARIETY [IF KNOWN]: Patton Engraved, var. Patton 
SITE NAME OR SITE NUMBER: Jim P. Allen

VESSEL NO.: 41CE12-188; Burial AH-16

NON-PLASTICS AND PASTE: grog and hematite

VESSEL FORM: Globular Bowl

RIM AND LIP FORM: Direct rim and rounded lip

CORE COLOR: A (fired and cooled in an oxidizing environment)

INTERIOR SURFACE COLOR: strong brown

EXTERIOR SURFACE COLOR: strong brown; fire clouds on the rim and body

WALL THICKNESS (RIM, BODY, AND BASE

IN MM): rim, $5.4 \mathrm{~mm}$

INTERIOR SURFACE TREATMENT: smoothed on the rim and body

EXTERIOR SURFACE TREATMENT: smoothed on the rim and body

HEIGHT (IN CM): 10.4

ORIFICE DIAMETER (IN CM): 12.0

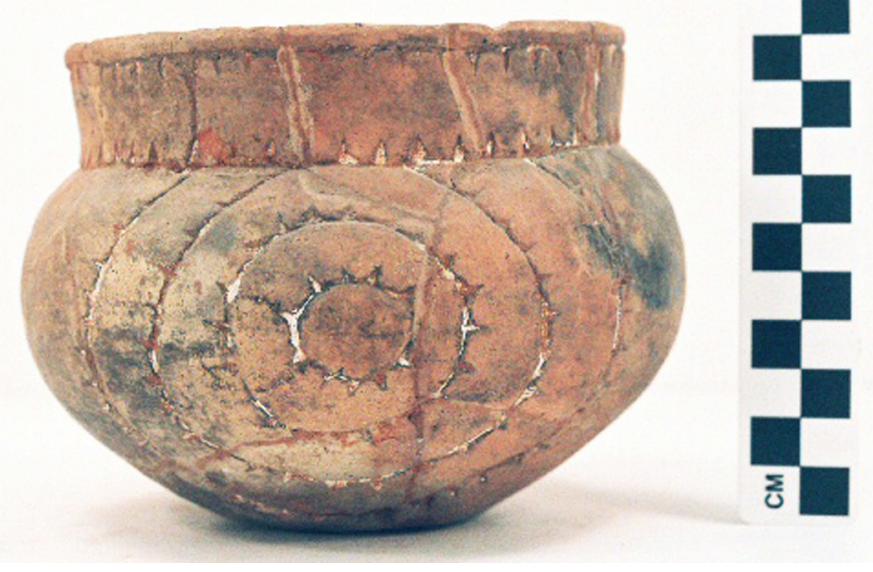

Figure 127. Patton Engraved, var. Freeman globular bowl from the Jim P. Allen site.

DIAMETER AT BOTTOM OF RIM OR NECK (IN CM): 11.4

BASE DIAMETER (IN CM) AND SHAPE OF BASE: 6.0; circular and flat

ESTIMATED VOLUME (IN LITERS): 1.0

DECORATION (INCLUDING MOTIF AND ELEMENTS WHEN APPARENT): The rim panel is defined by single upper and lower horizontal engraved lines with either downward- or upward-pointing excised tick marks. The panel is divided into four rectangular sections by vertical excised lines that end in excised tick marks (Figure 127). The vessel body has three sets of engraved concentric circles, and each circle has outward-pointing excised tick marks on them.

PIGMENT USE AND LOCATION ON VESSEL: white pigment in engraved lines TYPE AND VARIETY [IF KNOWN]: Patton Engraved, var. Freeman 
SITE NAME OR SITE NUMBER: Jim P. Allen

VESSEL NO.: 41CE12-189; Burial AH-17

NON-PLASTICS AND PASTE: bone, grog, and hematite

VESSEL FORM: Globular Bowl

RIM AND LIP FORM: Direct rim and rounded lip

CORE COLOR: $\mathrm{F}$ (fired in a reducing environment and cooled in the open air)

INTERIOR SURFACE COLOR: brown

EXTERIOR SURFACE COLOR: brown

WALL THICKNESS (RIM, BODY, AND BASE

IN MM): rim, $5.3 \mathrm{~mm}$

INTERIOR SURFACE TREATMENT: smoothed on the rim and body

EXTERIOR SURFACE TREATMENT: burnished on the rim and body

HEIGHT (IN CM): 9.8

ORIFICE DIAMETER (IN CM): 12.5

DIAMETER AT BOTTOM OF RIM OR NECK

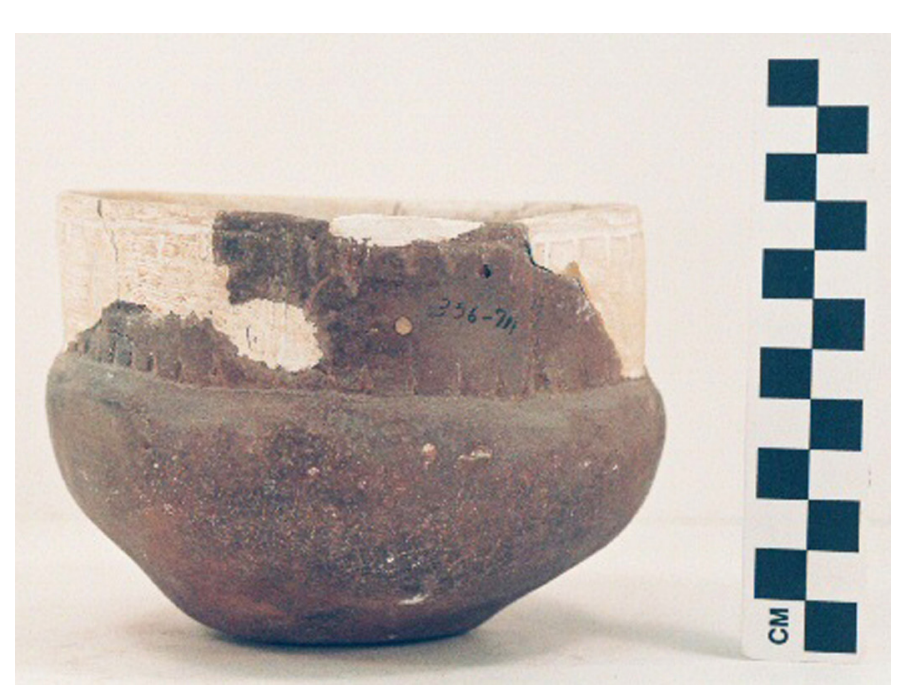

Figure 128. Poynor Engraved, var. Freeman globular bowl from the Jim P. Allen site. (IN CM): 12.5

BASE DIAMETER (IN CM) AND SHAPE OF BASE: 4.9; circular and flat

ESTIMATED VOLUME (IN LITERS): 1.0

DECORATION (INCLUDING MOTIF AND ELEMENTS WHEN APPARENT): The rim panel is defined by single upper and lower horizontal engraved lines with either downward- or upward-pointing excised tick marks. The panel is divided into seven rectangular sections by open vertical engraved brackets (Figure 128).

PIGMENT USE AND LOCATION ON VESSEL: none

TYPE AND VARIETY [IF KNOWN]: Poynor Engraved, var. Freeman 
SITE NAME OR SITE NUMBER: Jim P. Allen

VESSEL NO.: 41CE12-190; Burial AH-17

NON-PLASTICS AND PASTE: grog and hematite; fine sandy paste

VESSEL FORM: Globular Bowl

RIM AND LIP FORM: Direct rim and rounded lip

CORE COLOR: A (fired and cooled in an oxidizing environment)

INTERIOR SURFACE COLOR: yellowish-brown

EXTERIOR SURFACE COLOR: yellowish-

brown; fire clouds on the body and base

WALL THICKNESS (RIM, BODY, AND BASE

IN MM): rim, $3.9 \mathrm{~mm}$

INTERIOR SURFACE TREATMENT: smoothed on the rim and body

EXTERIOR SURFACE TREATMENT: smoothed on the rim

HEIGHT (IN CM): 7.0

ORIFICE DIAMETER (IN CM): 9.5

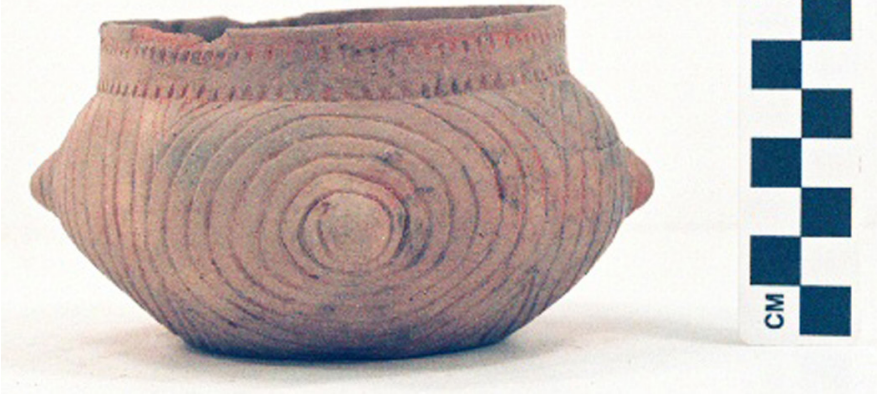

Figure 129. Patton Engraved, var. unspecified globular bowl from the Jim P. Allen site.

DIAMETER AT BOTTOM OF RIM OR NECK (IN CM): 9.6; $11.8 \mathrm{~cm}$ at the widest point on the body

BASE DIAMETER (IN CM) AND SHAPE OF BASE: 6.3; circular and flat

ESTIMATED VOLUME (IN LITERS): 0.5

DECORATION (INCLUDING MOTIF AND ELEMENTS WHEN APPARENT): The rim panel has single upper and lower horizontal engraved lines with either downward- or upward-pointing excised tick marks. The vessel body has four sets of engraved concentric circles, and there is a large appliqued node at the center of each set of engraved circles (Figure 129). The sets of concentric circles are divided by large upper and lower pendant triangles, and each large pendant triangle has two inner triangular elements.

PIGMENT USE AND LOCATION ON VESSEL: none

TYPE AND VARIETY [IF KNOWN]: Patton Engraved, var. unspecified 
SITE NAME OR SITE NUMBER: Jim P. Allen

VESSEL NO.: 41CE12-191; Burial AH-17

NON-PLASTICS AND PASTE: grog and hematite

VESSEL FORM: Globular Bowl

RIM AND LIP FORM: Direct rim and rounded lip

CORE COLOR: A (fired and cooled in an oxidizing environment)

INTERIOR SURFACE COLOR: yellowish-brown

EXTERIOR SURFACE COLOR: brown; fire

clouds on the body and base

WALL THICKNESS (RIM, BODY, AND BASE

IN MM): rim, $5.1 \mathrm{~mm}$

INTERIOR SURFACE TREATMENT: smoothed on the rim and body

EXTERIOR SURFACE TREATMENT: smoothed on the rim and body

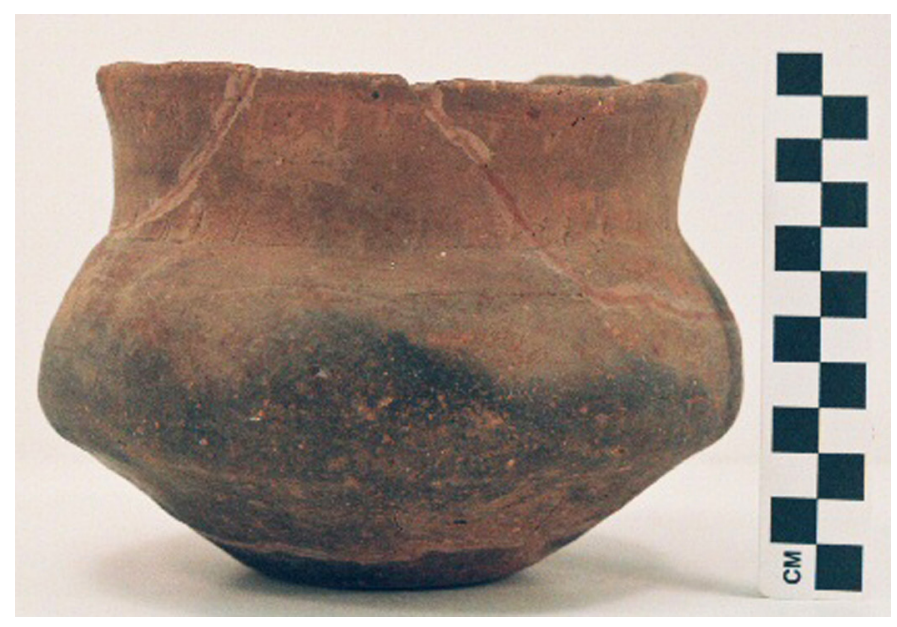

HEIGHT (IN CM): 12.0

Figure 130. Patton Engraved, var. unspecified globular bowl from the Jim P. Allen site.

ORIFICE DIAMETER (IN CM): 14.1

DIAMETER AT BOTTOM OF RIM OR NECK (IN CM): $16.9 \mathrm{~cm}$ at the widest point on the body

BASE DIAMETER (IN CM) AND SHAPE OF BASE: 7.4; circular and flat

ESTIMATED VOLUME (IN LITERS): 1.3

DECORATION (INCLUDING MOTIF AND ELEMENTS WHEN APPARENT): The rim panel is decorated with single upper and lower horizontal engraved lines. The engraved lines have either downwardor upward-pointing excised tick marks (Figure 130).

PIGMENT USE AND LOCATION ON VESSEL: none

TYPE AND VARIETY [IF KNOWN]: Patton Engraved, var. unspecified 
SITE NAME OR SITE NUMBER: Jim P. Allen site

VESSEL NO.: 41CE12-192; Burial AN-17

NON-PLASTICS AND PASTE: grog and hematite

VESSEL FORM: Globular Bowl

RIM AND LIP FORM: Direct rim and rounded lip

CORE COLOR: A (fired and cooled in an oxidizing environment)

INTERIOR SURFACE COLOR: brown

EXTERIOR SURFACE COLOR: yellowishbrown; fire clouds on the rim and body

WALL THICKNESS (RIM, BODY, AND BASE IN MM): $\operatorname{rim}, 6.1 \mathrm{~mm}$

INTERIOR SURFACE TREATMENT: smoothed on the rim and body

EXTERIOR SURFACE TREATMENT: smoothed on the rim and body

HEIGHT (IN CM): 18.3

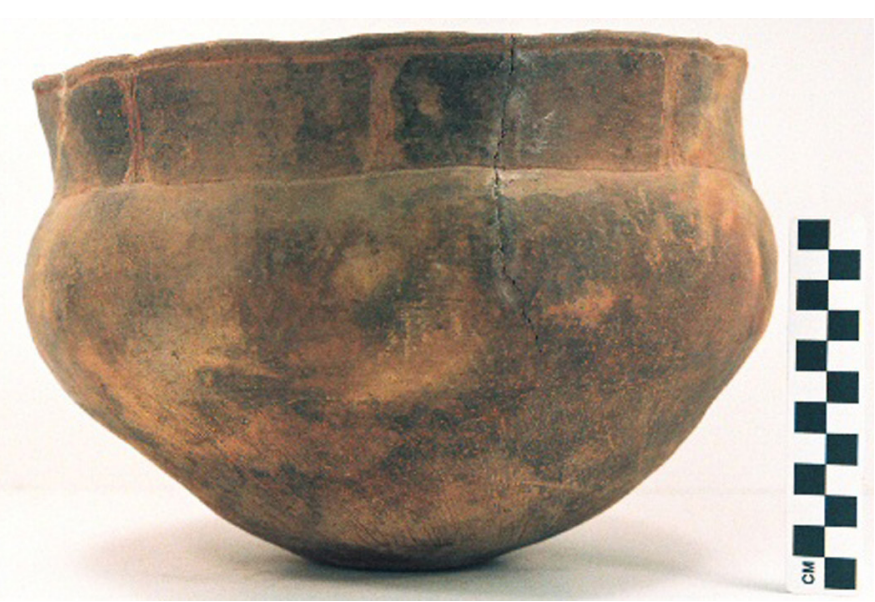

Figure 131. Poynor Engraved, var. Hood globular bowl from the Jim P. Allen site.

ORIFICE DIAMETER (IN CM): 25.9

DIAMETER AT BOTTOM OF RIM OR NECK (IN CM): $27.4 \mathrm{~cm}$ at the widest part of the body

BASE DIAMETER (IN CM) AND SHAPE OF BASE: 7.5; circular and flat

ESTIMATED VOLUME (IN LITERS): 4.4

DECORATION (INCLUDING MOTIF AND ELEMENTS WHEN APPARENT): The rim panel is decorated with single upper and lower horizontal engraved lines. The panel is divided into nine rectangular sections by a series of excised vertical brackets (Figure 131). The vessel body has vertical and diagonal brushing marks.

PIGMENT USE AND LOCATION ON VESSEL: red pigment in engraved lines

TYPE AND VARIETY [IF KNOWN]: Poynor Engraved, var. Hood 
SITE NAME OR SITE NUMBER: Jim P. Allen

VESSEL NO.: 41CE12-193; Burial AH-18

NON-PLASTICS AND PASTE: grog and hematite

VESSEL FORM: Bottle with a cylindrical body and short neck

RIM AND LIP FORM: Direct rim and flat lip

CORE COLOR: A (fired and cooled in an oxidizing environment)

INTERIOR SURFACE COLOR: brownish-yellow

EXTERIOR SURFACE COLOR: brownish-yellow; fire clouds on the body

WALL THICKNESS (RIM, BODY, AND BASE IN $\mathrm{MM})$ : rim, $6.2 \mathrm{~mm}$

INTERIOR SURFACE TREATMENT: none

EXTERIOR SURFACE TREATMENT: smoothed on the rim and body

HEIGHT (IN CM): 19.6

ORIFICE DIAMETER (IN CM): 4.1

DIAMETER AT BOTTOM OF RIM OR NECK (IN

$\mathrm{CM}): 5.1 ; 11.0 \mathrm{~cm}$ at the widest point on the body

BASE DIAMETER (IN CM) AND SHAPE OF BASE:

7.7; circular and flat

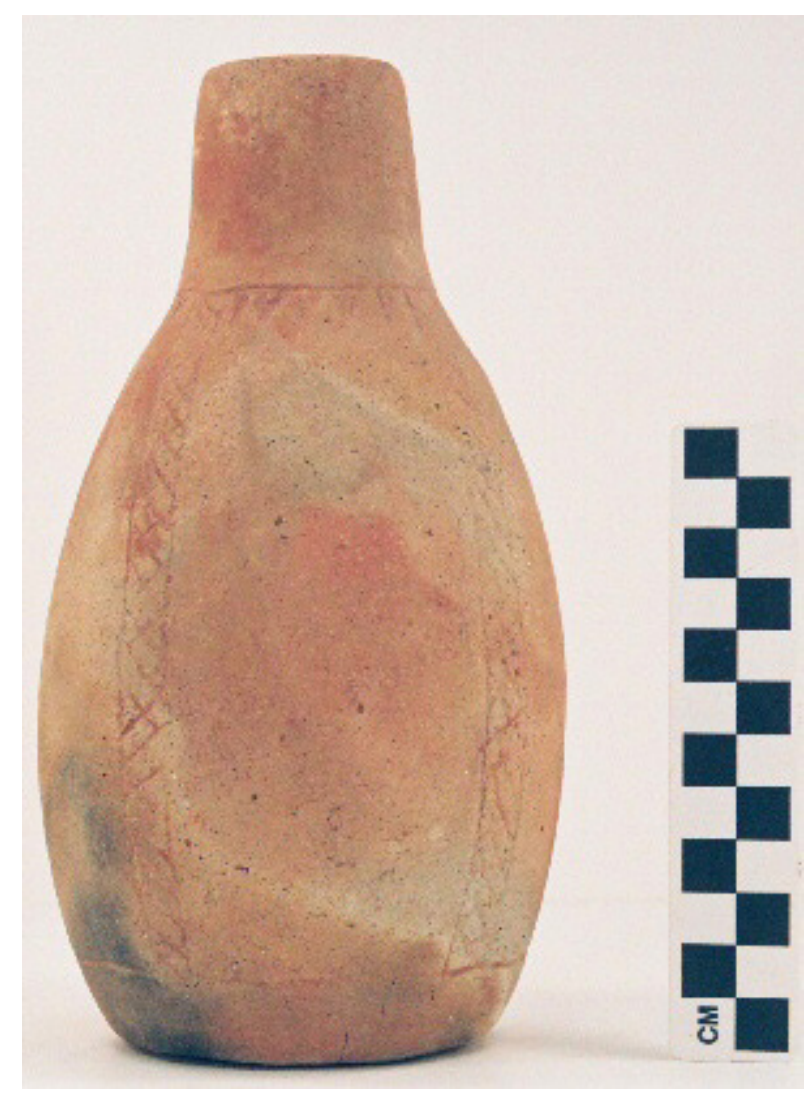

Figure 132. Hume Engraved, var. unspecified bottle from the Jim P. Allen site.

ESTIMATED VOLUME (IN LITERS): 0.6

DECORATION (INCLUDING MOTIF AND ELEMENTS WHEN APPARENT): There is a single horizontal engraved line at the top of the vessel body, and another horizontal line near the base. The topmost engraved line has a series of large downward-pointing excised triangles (Figure 132). There are four narrow vertical zones or bands between the two horizontal engraved lines, and they are filled with cross-hatched engraved lines.

PIGMENT USE AND LOCATION ON VESSEL: none

TYPE AND VARIETY [IF KNOWN]: Hume Engraved, var. unspecified 
SITE NAME OR SITE NUMBER: Jim P. Allen

VESSEL NO.: 41CE12-194; Burial AH-18

NON-PLASTICS AND PASTE: grog and hematite

VESSEL FORM: Bottle with a collared neck, cylindrical body, and short neck

RIM AND LIP FORM: Direct rim and rounded lip

CORE COLOR: A (fired and cooled in an oxidizing environment)

INTERIOR SURFACE COLOR: brownish-yellow

EXTERIOR SURFACE COLOR: brownish-yellow; fire clouds on the base

WALL THICKNESS (RIM, BODY, AND BASE IN $\mathrm{MM})$ : rim, $5.8 \mathrm{~mm}$

INTERIOR SURFACE TREATMENT: none

EXTERIOR SURFACE TREATMENT: smoothed on the rim and body

HEIGHT (IN CM): 26.5

ORIFICE DIAMETER (IN CM): 4.1

DIAMETER AT BOTTOM OF RIM OR NECK (IN $\mathrm{CM}): 15.8 \mathrm{~cm}$ at the widest point on the vessel body

BASE DIAMETER (IN CM) AND SHAPE OF

BASE: 8.5; circular and flat

ESTIMATED VOLUME (IN LITERS): 0.9

DECORATION (INCLUDING MOTIF AND ELEMENTS WHEN APPARENT): There is a single horizontal engraved line at the top of the vessel body and below the vessel collar, and another horizontal line near the base. There are four narrow vertical zones or bands between the two horizontal engraved lines, and they are filled with cross-hatched engraved lines (Figure 133).

PIGMENT USE AND LOCATION ON VESSEL: none

TYPE AND VARIETY [IF KNOWN]: Hume Engraved, var. Hume 
SITE NAME OR SITE NUMBER: Jim P. Allen

VESSEL NO.: 41CE12-195

NON-PLASTICS AND PASTE: grog and hematite

VESSEL FORM: Globular bowl

RIM AND LIP FORM: Direct rim and rounded lip

CORE COLOR: A (fired and cooled in an oxidizing environment)

INTERIOR SURFACE COLOR: very pale brown; fire clouds on the base

EXTERIOR SURFACE COLOR: very pale brown; fire clouds on the rim, body, and base

WALL THICKNESS (RIM, BODY, AND BASE IN MM): rim, $4.1 \mathrm{~mm}$

INTERIOR SURFACE TREATMENT: smoothed on the rim and body

EXTERIOR SURFACE TREATMENT: smoothed on the rim and body

HEIGHT (IN CM): 9.9

ORIFICE DIAMETER (IN CM): 10.1

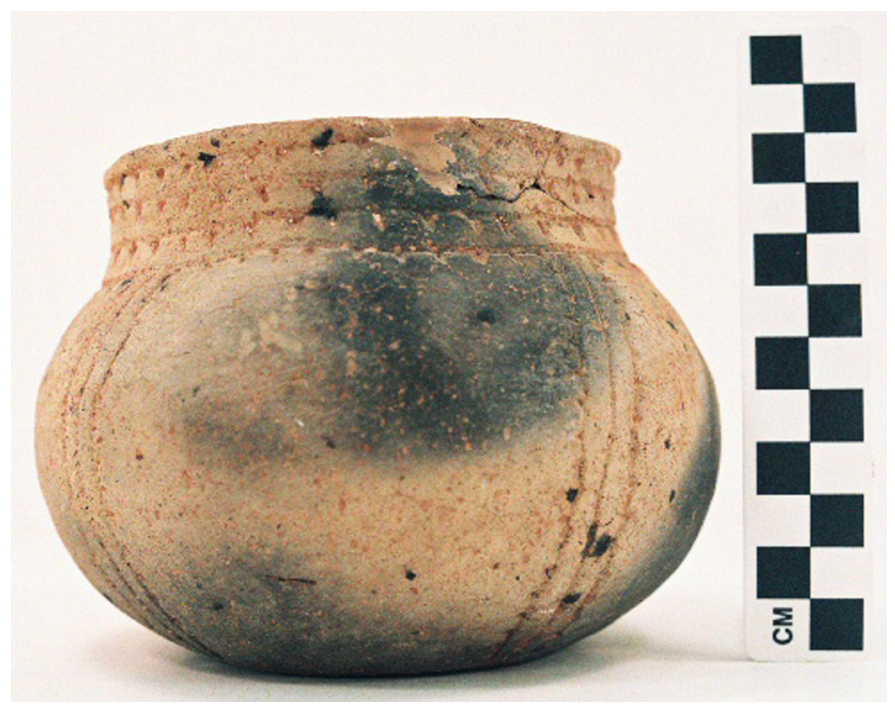

Figure 134. Patton Engraved, var. unspecified globular bowl from the Jim P. Allen site.

DIAMETER AT BOTTOM OF RIM OR NECK (IN CM): 10.5

BASE DIAMETER (IN CM) AND SHAPE OF BASE: 7.8; circular and flat

ESTIMATED VOLUME (IN LITERS): 0.8

DECORATION (INCLUDING MOTIF AND ELEMENTS WHEN APPARENT): The rim has four horizontal engraved lines with downward-pointing excised tick marks. The vessel body has four sets of three closely-spaced diagonal engraved lines that extend from the rim to the base (Figure 134). The two outer engraved lines have outward-pointing excised tick marks on them.

PIGMENT USE AND LOCATION ON VESSEL: white pigment in the engraved lines

TYPE AND VARIETY [IF KNOWN]: Patton Engraved, var. unspecified 


\section{R. F. Wallace Site (41CE20) Vessel}

The one vessel from the R. F. Wallace site was found by the landowner from a disturbed Caddo burial that was washed out of the site during flooding (Jackson 1932). In June 1932, UT archeologists excavated a 26 x $36 \mathrm{ft}$. area in search of other burials from the site, and located a second disturbed burial and a nearby midden area. This burial did not have any associated ceramic vessels as funerary offerings, but two glass beads were recovered in the burial fill. The recovered sherds from the R. F. Wallace site suggest that it is primarily a small Historic Caddo Allen phase occupation with Patton Engraved sherds ( $\mathrm{n}=9$ ), Poynor Engraved sherds $(n=3)$, as well as sherds from utility wares such as La Rue Neck Banded $(n=2)$ and Maydelle Incised $(n=2)$, along with many brushed $(n=147)$, brushed-punctated $(n=10)$, and brushedpunctated-appliqued $(n=3)$ sherds.

SITE NAME OR SITE NUMBER: R. F. Wallace

VESSEL NO.: 41CE20-1

NON-PLASTICS AND PASTE: grog

VESSEL FORM: Bottle with a short neck

RIM AND LIP FORM: Direct rim and rounded lip

CORE COLOR: G (fired in a reducing environment and cooled in the open air)

INTERIOR SURFACE COLOR: very dark gray

EXTERIOR SURFACE COLOR: light brown; fire clouds on the neck and body

WALL THICKNESS (RIM, BODY, AND BASE IN MM): rim, 6.3 mm

INTERIOR SURFACE TREATMENT: none

EXTERIOR SURFACE TREATMENT: burnished on the neck and body

HEIGHT (IN CM): 17.5

ORIFICE DIAMETER (IN CM): 6.5

DIAMETER AT BOTTOM OF RIM OR NECK (IN CM): 6.2

BASE DIAMETER (IN CM) AND SHAPE OF BASE: 8.5

ESTIMATED VOLUME (IN LITERS): 0.6 
DECORATION (INCLUDING MOTIF AND ELEMENTS WHEN APPARENT): Vertical engraved panels (four on the body) filled with vertical scrolls, hatched triangles, and concentric circles and semi-circles. One of the circles has central hatched lines, and hatched oval areas also have excised spurs. The panels are divided by a single vertical engraved line and there are three horizontal engraved lines that encircle the bottle at the top of the neck (Figure 135).

PIGMENT USE AND LOCATION ON VESSEL: none

TYPE AND VARIETY [IF KNOWN]: possible Poynor Engraved

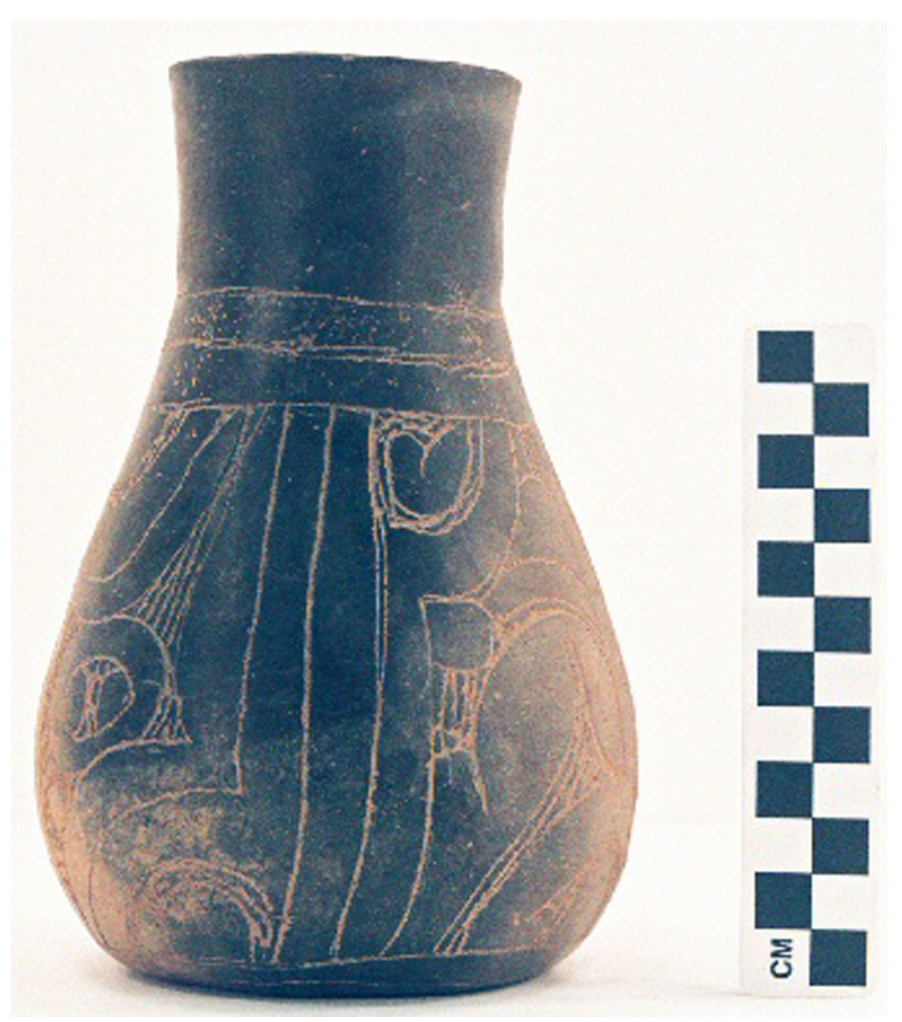

Figure 135. Engraved bottle from the R. F. Wallace site. 


\section{Summary and Conclusions}

This report has described the 129 ceramic vessels that were recovered from seven ancestral Caddo sites in the upper Neches River basin in Anderson and Cherokee counties, in East Texas. These vessels, in the collections of the Texas Archeological Research Laboratory at The University of Texas at Austin, come from burials in Caddo sites that appear to date either to the latter part of the Frankston phase (subphase 3, dating ca. A.D. 1560-1650) or to some part of the Allen phase (ca. A.D. 1650-1800). Several of the Allen phase burials also have a few European trade goods, suggesting they were interred sometime between ca. A.D. 1680 and ca. A.D. 1720, after which European trade goods become more common in Hasinai Caddo sites in the region (see Marceaux and Perttula 2010; Marceaux and Wade 2014).

\section{Upper Neches River Caddo Ceramic Tradition}

There is a temporally distinctive and spatially coherent Caddo ceramic tradition in the upper Neches River basin in East Texas (Figure 136). The temporal framework of this ancestral Caddo ceramic tradition comes from the seriation of engraved fine ware vessels from mortuary contexts throughout the region, a more detailed seriation of specific Poynor Engraved rim motifs (see Perttula et al. 2011:Table 6-37) from a large sample of burial vessels, and extensive radiocarbon and TL dating from the Lang Pasture site (41AN38) and selected other Caddo sites in the upper Neches River basin. This framework includes a ca. A.D. 1320-1400 component at the Lang Pasture site, sub-phase 1 (ca. A.D. 1400-1480), sub-phase 2 (ca. A.D. 1480-1560), and sub-phase 3 (ca. A.D. 1560-1650) of the Frankston phase, and the post-A.D. 1650 Allen phase. The ceramic tradition probably lasted through the 18th century, but its ending point in the upper Neches River basin has not been established with any certainty. Important fine wares in this tradition include several varieties of Hood Engraved, Hume Engraved, Patton Engraved, and Poynor Engraved, while important utility wares are represented by Bullard Brushed, Killough Pinched, and Maydelle Incised jars and other vessel forms (Perttula et al. 2011:Table 6-35).

The spatial context for this Late Caddo ceramic tradition is a ca. $6600 \mathrm{~km}^{2}$ area of the upper Neches River basin (see Figure 136), of which the best-studied part is a $1700 \mathrm{~km}^{2}$ area centered on the Lang Pasture site (41AN38; see Perttula et al. 2011), a number of small to medium-sized cemeteries, and domestic ceramic sherd assemblages primarily from the Lake Palestine area (cf. Anderson et al. 1974; Kleinschmidt 1982; Perttula and Middlebrook 2008). This broader upper Neches area is west of a second and broadly contemporaneous Late Caddo ceramic tradition in the downstream portions of the Neches, Angelina, and Attoyac river basins to the east and southeast in East Texas that is dominated by bone-tempered brushed pottery and a different suite of engraved fine wares (see Jelks 1965; Story 1982; Middlebrook 1994; Fields 1995).

\section{Character of Mortuary Ceramics}

The mortuary ceramics from upper Neches River basin Caddo sites illustrate broad continuities in ceramic practice, particularly in terms of vessel decoration and vessel form, but they also demonstrate patterns in stylistic and technical choices that are very different than what has been documented in domestic Caddo ceramic assemblages of the same age and likely made by the same social group of potters. Domestic sherd assemblages in this part of East Texas that date after ca. A.D. 1400 are dominated by sherds from utility ware vessels, particularly sherds from vessels that feature brushed, incised, punctated, and other wet-paste decorative elements. Sherds from fine ware vessels are not common in domestic archeological deposits (see Perttula et al. 2011:Table 6-38), typically accounting for less than 10 percent of decorated sherd assemblages. 


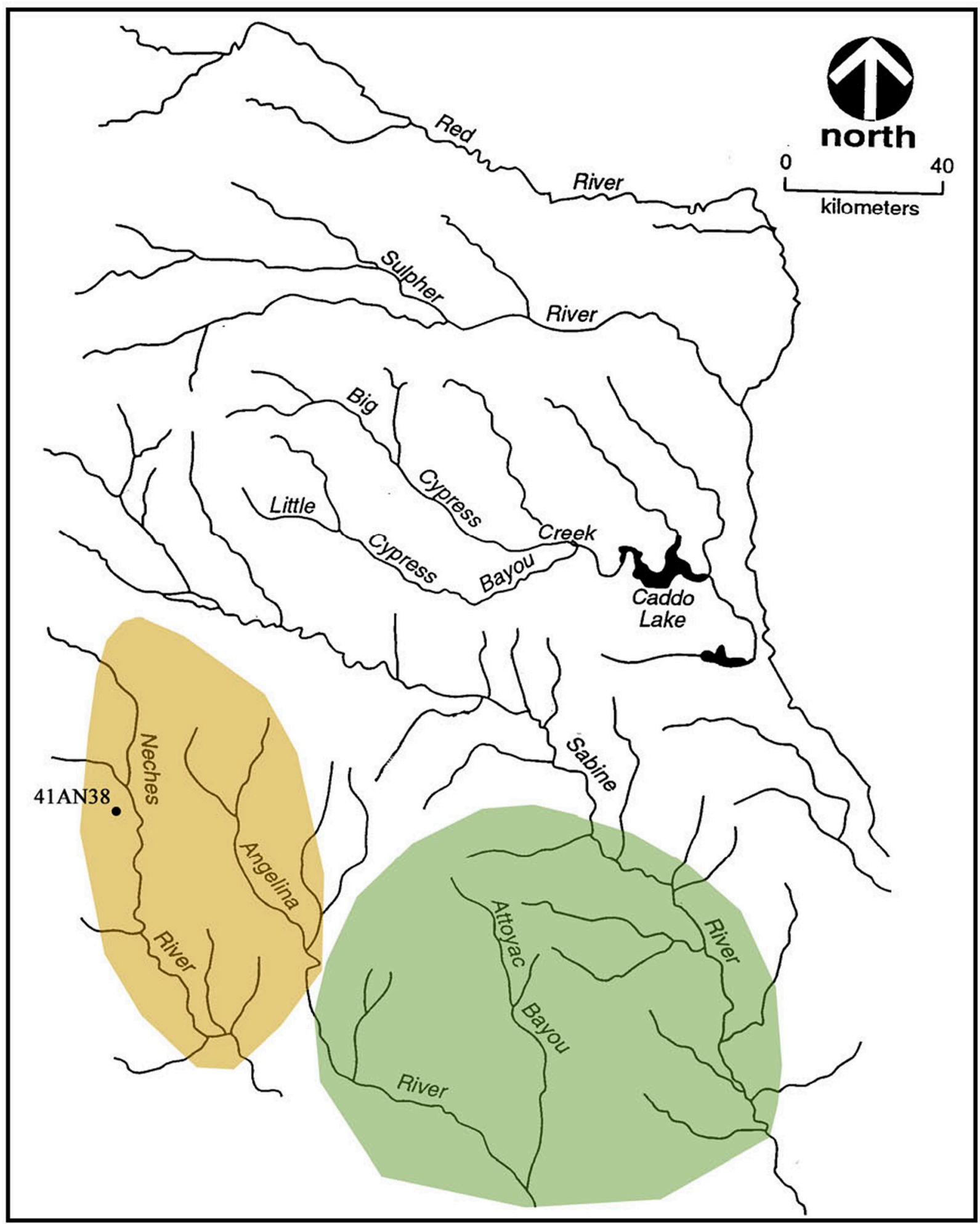

Figure 136. Late and Historic Caddo ceramic traditions in East Texas, south and west of the Sabine River. Upper Neches Frankston and Allen phases shown in brown, and bone-tempered brushed tradition shown in green (from Perttula et al. 2011:Figure 6-71). 
Ancestral Caddo mortuary ceramics in the upper Neches River basin, however, are dominated by fine wares: 73.3 percent of the ceramic vessel database from the basin are fine wares (Perttula et al. 2011:Table 6-35). Not surprisingly, then, the vessel assemblages discussed here are dominated by locally-manufactured fine wares $(\mathrm{n}=103,80$ percent of the assemblage as a whole), along with locally manufactured utility wares $(n=15,11.6$ percent), locally-made plain wares $(n=4,3.1$ percent $)$, and non-locally-manufactured fine wares $(n=7,5.4$ percent).

\section{Vessel Form}

The principal vessel forms in these assemblages are globular bowls (41.9 percent of the vessel assemblage), carinated bowls (20.9 percent), and bottles of various neck ands body forms (16.3 percent) (Table 1). Bowls and jars, respectively, only comprise between 6.2-7.0 percent of the vessels, and the distinctive Hood Engraved effigy bowls represent another 4.7 percent of the vessel assemblage. Two vessel forms the spool neck bottle and the deep bowl (see Table 1) - are associated only with non-local fine wares.

Table 1. Vessel forms represented in these upper Neches River basin assemblages.

\begin{tabular}{|c|c|c|c|c|c|c|c|c|}
\hline Vessel Form & AN13 & AN21 & AN26 & AN34 & CE6 & CE12 & CE20 & $\mathrm{N}$ \\
\hline Bowl & 3 & 1 & 4 & - & - & 1 & - & 9 \\
\hline Carinated Bowl & 8 & - & 6 & 4 & 1 & 8 & - & 27 \\
\hline $\begin{array}{l}\text { Bowl or Carinated } \\
\text { Bowl }\end{array}$ & - & - & - & - & - & 1 & - & 1 \\
\hline Globular Bowl & 3 & - & 18 & 11 & 2 & 20 & - & 54 \\
\hline $\begin{array}{l}\text { Globular Bowl, } \\
\text { conjoined }\end{array}$ & - & - & - & - & - & 1 & - & 1 \\
\hline Effigy bowl & - & - & - & - & - & 1 & - & 1 \\
\hline $\begin{array}{l}\text { Effigy bowl, with } \\
\text { tail rider }\end{array}$ & - & - & - & 1 & 1 & 3 & - & 5 \\
\hline Bottle & - & - & - & - & - & 1 & - & 1 \\
\hline $\begin{array}{l}\text { Bottle, with } \\
\text { cylindrical body }\end{array}$ & - & - & - & 1 & - & 9 & - & 10 \\
\hline $\begin{array}{l}\text { Bottle, with } \\
\text { collared neck }\end{array}$ & - & - & 1 & - & - & 1 & - & 2 \\
\hline $\begin{array}{l}\text { Bottle, with } \\
\text { short neck }\end{array}$ & - & - & - & - & 2 & 4 & 1 & 7 \\
\hline $\begin{array}{l}\text { Bottle, with spool } \\
\text { neck }\end{array}$ & - & - & - & - & 1 & - & - & 1 \\
\hline Jar & 2 & - & - & 2 & - & 4 & - & 8 \\
\hline Jar or Deep bowl & - & - & - & - & 1 & - & - & 1 \\
\hline Deep Bowl & - & - & - & - & - & 1 & - & 1 \\
\hline Totals & 16 & 1 & 29 & 19 & 8 & 55 & 1 & 129 \\
\hline
\end{tabular}


Bowls, carinated bowls, and globular bowls account for 70 percent of the vessel assemblage. This is comparable to the proportions of bowls in a number of Frankston phase vessel assemblages in the upper Neches River basin: 60.2-74.4 percent (Perttula et al. 2011:Table 6-31). Simple bowls are really only abundant in ca. A.D. 1320-1480 Frankston phase cemeteries; their proportions decrease through the span of the Frankston phase. Short-necked bottle forms occur in mortuary contexts from ca. A.D. 1480 on. Bottles in general increase in frequency as mortuary offerings after ca. A.D. 1480 as well, and this seems mirrored by the frequency of bottles in the Jim P. Allen vessel assemblage (27 percent, see Table 1).. Utility ware jars are not particularly common in any upper Neches Caddo cemeteries, except perhaps in subphase 2 times (ca. A.D. 1480-1560).

\section{Vessel Size}

Mortuary vessels in upper Neches River Caddo sites were made in a wide variety of sizes. Surely these vessels held liquids and foodstuffs for the deceased to use on the journey to the House of Death. In most cases, the vessels included with the deceased by his or her living relatives easily would have held multiple servings of food and liquids (perhaps enough to last for the 6 day journey). In the vessel assemblages discussed in this report, vessel size ranges from as little as 0.1 liters to greater than 4.5 liters (Table 2).

Table 2. Vessel size (in liters) in these upper Neches River basin assemblages.

\begin{tabular}{lcccccccc}
\hline $\begin{array}{l}\text { Size } \\
\text { (in liters) }\end{array}$ & Bw & CB & GB & Jar & Bt & $\begin{array}{r}\text { Effigy } \\
\text { Bowl }\end{array}$ & $\begin{array}{c}\text { Deep } \\
\text { Bowl }\end{array}$ & N \\
\hline $0.1-0.5$ & 8 & 5 & 10 & 1 & 7 & 2 & - & 33 \\
$0.51-1.0$ & - & 5 & 22 & 3 & 8 & 4 & - & 42 \\
$1.01-1.5$ & - & 2 & 12 & - & 2 & - & 1 & 17 \\
$1.51-2.0$ & - & 1 & 4 & - & - & - & - & 5 \\
$2.01-2.5$ & - & 1 & 2 & - & - & - & - & 3 \\
$2.51-3.0$ & - & 1 & 1 & - & - & - & - & 2 \\
$3.01-3.5$ & - & 1 & 1 & - & - & - & - & 2 \\
$3.51-4.0$ & 1 & 3 & - & - & - & - & - & 4 \\
$4.01-4.5$ & - & 5 & 1 & - & - & - & - & 6 \\
$>4.5$ & - & 3 & - & - & - & - & - & 3 \\
Totals & 9 & 27 & 53 & 4 & 17 & 6 & 1 & 117 \\
\hline
\end{tabular}

$\mathrm{Bw}=$ bowl; $\mathrm{CB}=$ carinated bowl; $\mathrm{GB}=$ globular bowl (referred to by Perttula et al. 2011:Figure 6-27d as a carinated bowl with a globular body); $\mathrm{Bt}=$ bottle

With one exception, bowls are small in size. Carinated bowls tend to be either small (0.1-1.0 liter) or very large (3.5->4.5 liters), while globular bowls are primarily small to medium-sized (0.1-1.5 liters) in size (see Table 2). The very large size of some of the carinated bowls (food serving vessels) in post-A.D. 1480 Caddo cemeteries in the upper Neches River basin would have been well-suited for communal food serving, which suggests that the vessels may have been intended by the Caddo to serve multiple purposes in mortuary rituals. These could have included use of the vessels in grave-side rituals and daily food offerings by the relatives of the deceased, after which they were placed in the graves as final accompaniment once the "Sixth Day Feast" had been concluded (see Gonzalez et al. 2005:57-58). These grave-side practices and changes in mortuary rituals seem to have begun around ca. A.D. 1480. Pre-A.D. 1480 
cemeteries in the upper Neches typically have only a range of small to medium-sized vessels, probably destined for individual use.

Jars are small in size in these assemblages. In other upper Neches River basin mortuary vessel assemblages, there are also miniature jars, large jars, and very large jars. Large amounts of food stuffs, enough for at least 10 servings, could have been held in these vessels. Bottles in these Caddo sites tend to have minimal differences in volume, ranging from 0.1-1.5 liters. With the appearance of elongated and cylindrical body/short-necked Hume Engraved vessels in post-A.D. 1480 contexts, the volume of bottles to hold liquids increased substantially. This trend for increased vessel size and volume after ca. A.D. 1480 is in step with volume size trends seen in the carinated bowls and jars.

\section{Ceramic Types represented in the Assemblage}

The local fine ware types and varieties in this vessel collection all have engraved motifs and design elements (Table 3). The include two varieties of Hood Engraved effigy bowls in three sites, two varieties of Hume Engraved bottles, primarily from the Jim P. Allen site, four varieties of Patton Engraved (as well as an incised variety dubbed Patton Incised) - best represented at the Jim P. Allen, Richard Patton, and R. L. Jowell sites - and five varieties of Poynor Engraved, particularly well represented at the Pierce Freeman and Jim P. Allen sites.

Table 3. Ceramic types and varieties in these upper Neches River basin assemblages.

\begin{tabular}{|c|c|c|c|c|c|c|c|c|}
\hline Type and variety & AN13 & AN21 & AN26 & AN34 & CE6 & CE12 & CE20 & $\mathrm{N}$ \\
\hline \multicolumn{9}{|l|}{ Local fine ware } \\
\hline Hood Engraved, var. Allen & - & - & - & 1 & 1 & 3 & - & 5 \\
\hline Hood Engraved, var. Hood & - & - & - & - & - & 1 & - & 1 \\
\hline Subtotal, Hood Engraved & - & - & - & 1 & 1 & 4 & - & 6 \\
\hline Hume Engraved, var. Allen & - & - & - & - & - & 1 & - & 1 \\
\hline Hume Engraved, var. Hume & - & - & - & 1 & - & 3 & - & 4 \\
\hline $\begin{array}{l}\text { Hume Engraved, var. } \\
\text { unspecified }\end{array}$ & - & - & - & - & - & 5 & - & 5 \\
\hline $\begin{array}{l}\text { cf. Hume Engraved, } \\
\text { var. unspecified }\end{array}$ & - & - & - & - & - & 1 & - & 1 \\
\hline Subtotal, Hume Engraved & - & - & - & 1 & - & 9 & - & 10 \\
\hline Patton Engraved, var. Allen & - & - & 4 & - & - & 4 & - & 8 \\
\hline $\begin{array}{l}\text { cf. Patton Engraved, } \\
\text { var. Allen }\end{array}$ & - & - & 1 & - & - & - & & 1 \\
\hline Patton Engraved, var. Fair & - & - & 1 & - & 1 & - & - & 2 \\
\hline $\begin{array}{l}\text { cf. Patton Engraved, } \\
\text { var. Fair }\end{array}$ & - & - & 1 & - & - & 1 & - & 2 \\
\hline $\begin{array}{l}\text { Patton Engraved, var. } \\
\text { Freeman }\end{array}$ & 2 & - & 8 & - & 1 & 1 & - & 12 \\
\hline $\begin{array}{l}\text { cf. Patton Engraved, var. } \\
\text { Freeman }\end{array}$ & 2 & 1 & 1 & - & - & 1 & - & 5 \\
\hline $\begin{array}{l}\text { Patton Engraved, } \\
\text { var. Patton }\end{array}$ & 5 & - & 4 & 1 & 1 & 1 & - & 12 \\
\hline
\end{tabular}


Table 3. Ceramic types and varieties in these upper Neches River basin assemblages, cont.

\begin{tabular}{|c|c|c|c|c|c|c|c|c|}
\hline Type and variety & AN13 & AN21 & AN26 & AN34 & CE6 & CE12 & CE20 & $\mathrm{N}$ \\
\hline $\begin{array}{l}\text { cf. Patton Engraved, var. } \\
\text { Patton }\end{array}$ & - & - & 1 & - & - & - & - & 1 \\
\hline $\begin{array}{l}\text { Patton Engraved, var. } \\
\text { unspecified }\end{array}$ & 1 & - & 2 & - & - & 4 & - & 7 \\
\hline Subtotal, Patton Engraved & 10 & 1 & 23 & 1 & 3 & 12 & - & $\mathbf{5 0}$ \\
\hline Patton Incised & - & - & 1 & - & - & - & - & 1 \\
\hline $\begin{array}{l}\text { Poynor Engraved, var. } \\
\text { Blackburn }\end{array}$ & - & - & - & - & - & 2 & - & 2 \\
\hline Poynor Engraved, var. Cook & 1 & - & - & 1 & - & - & - & 2 \\
\hline $\begin{array}{l}\text { Poynor Engraved, var. } \\
\text { Freeman }\end{array}$ & - & - & 2 & 6 & - & 6 & - & 14 \\
\hline $\begin{array}{l}\text { cf. Poynor Engraved, } \\
\text { var. Freeman }\end{array}$ & - & - & - & 1 & 1 & 2 & - & 4 \\
\hline Poynor Engraved, var. Hood & - & - & - & 3 & - & 1 & - & 4 \\
\hline $\begin{array}{l}\text { Poynor Engraved, } \\
\text { var. } N\end{array}$ & - & - & - & 1 & - & - & - & 1 \\
\hline $\begin{array}{l}\text { Poynor Engraved, var. } \\
\text { unspecified }\end{array}$ & - & - & - & 1 & - & - & - & 1 \\
\hline $\begin{array}{l}\text { cf. Poynor Engraved, } \\
\text { var. unspecified }\end{array}$ & - & - & 1 & - & - & - & - & 1 \\
\hline $\begin{array}{l}\text { Subtotal, Poynor } \\
\text { Engraved }\end{array}$ & 1 & - & 3 & 13 & 1 & 11 & - & 29 \\
\hline
\end{tabular}

Non-local fine ware

cf. Avery Engraved

Hodges Engraved

Keno Trailed

Simms Engraved

Simms Engraved, var. Darco

$\begin{aligned} & \text { Subtotal, non-local fine } \\ & \text { wares }\end{aligned}$
-

\section{Local utility ware}

\begin{tabular}{lcccccccc} 
Bullard Brushed & 2 & - & - & 2 & - & 4 & - & 8 \\
Killough Pinched, var. Allen & - & - & - & - & - & 3 & - & 3 \\
\hline Totals & 13 & 1 & 27 & 18 & 6 & 50 & $-*$ & 115 \\
\hline
\end{tabular}

*the one vessel, an engraved bottle, resembles Poynor Engraved in decorative style 
Fine ware ceramic types in the assemblage that are considered to be of non-local origin and manufacture include Hodges Engraved, Keno Trailed, Simms Engraved, Simms Engraved, var. Darco, and a deep bowl with decorative elements that compare favorably to Avery Engraved (see Table 3). Although no chemical sourcing of these vessels have been completed, the decorative styles and tempers noted in these vessels in upper Neches cluster sites suggest they may have originated among Nadaco and Nasoni Caddo groups that were living along the middle Sabine (i.e., the Kinsloe phase, Fields and Gadus 2012; Jones 1968; Perttula 2007; Perttula and Nelson 2014), the Big Cypress (i.e., Nasoni at the Clements [41CS25] and Hunt [41CS23] sites, Perttula et al. 2010), and the Red River (i.e., Nasoni sites such as Hatchel [41BW3] and Eli Moores [41BW2] north of Texarkana, Perttula 2014) basins in East Texas (Figure 137).

The only typologically identified utility wares in this vessel assemblage are Bullard Brushed and one variety of Killough Pinched (see Table 3). The Killough Pinched, var. Allen vessels are cylindricallyshaped bottles, almost identical in form to Hume Engraved fine ware bottles, but they are decorated on their bodies with vertical rows of pinched ridges.

\section{Pigments}

Red or white clay pigments were commonly applied to the fine wares in the present vessel assemblage sample (Table 4). Pigments were used on carinated bowls, globular bowls, effigy bowls, and bottles, with the highest frequency of pigment use documented among the Hood Engraved effigy bowls (66.7 percent) and Patton Engraved bowls (60.8 percent). Almost 48 percent of the local fine wares have a clay pigment rubbed in the engraved decorative elements, compared to 57 percent of the non-local fine wares. White pigments were more commonly applied to local fine wares ( 37 percent), while red pigments were the only pigment applied on the non-local wares (Table 4); one unique Patton Engraved vessel had a red pigment on the engraved lines on the rim and a white pigment rubbed in the engraved elements on the body of a globular bowl.

Table 4. Use of pigments on fine ware vessels in these upper Neches River basin assemblages.

\begin{tabular}{|c|c|c|c|c|}
\hline $\begin{array}{l}\text { Types } \\
\text { or Decoration }\end{array}$ & red pigment & white pigment & $\begin{array}{l}\text { red/white } \\
\text { pigment }\end{array}$ & $\mathrm{N}$ \\
\hline
\end{tabular}

\section{Local fine wares}

Hood Engraved

Hume Engraved

Patton Engraved

Poynor Engraved

UID Engraved

Subtotal

$\begin{array}{rr}2 & 2 \\ 1 & - \\ 4 & 26 \\ 2 & 9 \\ 2 & - \\ 11 & 37\end{array}$

37

$\begin{array}{lr}- & 4 \\ - & 1 \\ 1 & 31 \\ - & 11 \\ - & 2 \\ 1 & 49\end{array}$

49

\section{Non-local fine wares}

Hodges Engraved

Simms Engraved

Subtotal
1

3

4

$\begin{array}{ll}- & 1 \\ - & 3 \\ - & 4\end{array}$




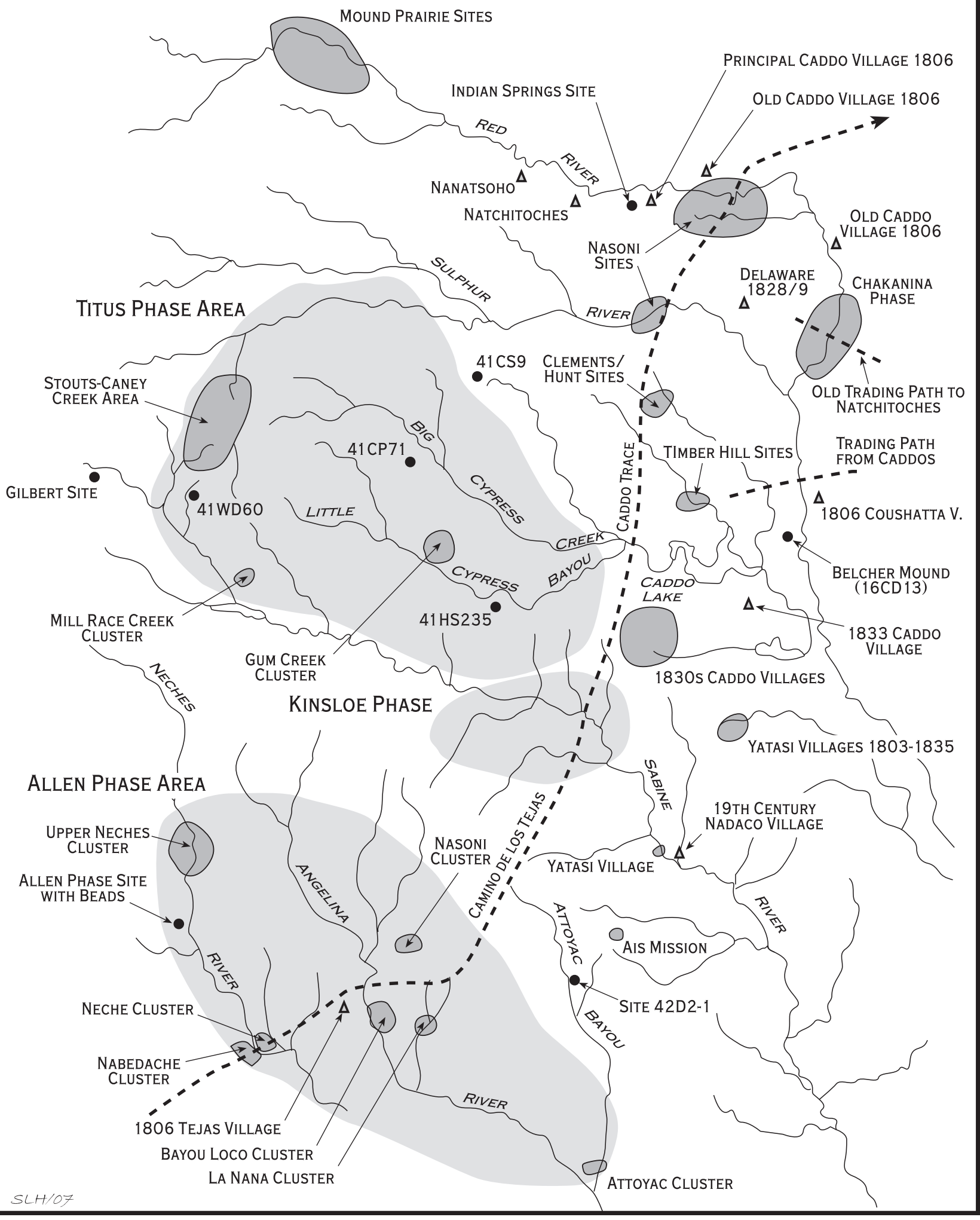

Figure 137. Historic Caddo sites and phase areas in East Texas. 
Both red and white clay pigments were used on the upper Neches mortuary vessels in the larger vessel dataset across the region. Red pigments were used on a few bowls and effigy bowls (9.3 percent of these vessels had a pigment), but almost exclusively on bottles ( 89 percent of the bottles had a red pigment in the engraved lines). Among the carinated bowls and globular bowls in the larger region-wide sample of vessels, almost 27 percent had a white clay pigment (with the remainder having a red pigment), particularly the carinated bowls from post-ca. A.D. 1560 Frankston phase cemeteries at the Fred McKee (50 percent) and R. J. Fair (100 percent) sites. In our present vessel assemblage, white pigments are common on both Patton Engraved (51 percent) and Poynor Engraved (31 percent) bowls, globular bowls, and carinated bowls (see Table 4).

There is an apparent temporal trend in the use by the Caddo living in the upper Neches River basin of clay pigments on mortuary vessels (Perttula et al. 2011:Table 6-34), even though the proportion of pigment use remains overall very consistent (16.4-16.7 percent) from the early (sub-phase 1) to the late (sub-phase 3) Frankston phase. The application of a red clay pigment was almost exclusively preferred on mortuary vessels used as funerary offerings up to ca. A.D. 1560 (ca. 92.5 percent of the vessels have a red clay pigment), but this began to be supplanted by a white clay pigment after that time. In sub-phase 2 contexts, 11 percent of the vessels have a white clay pigment, and this increases to 63.6 percent in subphase 3 times. This is good evidence that the present set of vessels discussed in this report are from burials in cemeteries that were used beginning after ca. A.D. 1560, since the use of white pigment as a vessel embellishment is so common in the assemblage (see Table 4).

Lankford (1992) has discussed the importance of the use of these two colors in social, political, and cosmological dualisms or divisions in Southeastern North American societies, and it is likely that similar dualisms characterized prehistoric Caddo groups living in the upper Neches. In the context of the use of different colors of pigments in mortuary rituals, Lankford (1992:76-77) suggests that the two colors symbolize the Lower world of change (red) and the Upper world of order (white). It is probable that the symbolic meaning and use of different pigments on mortuary vessels had cosmological significance to the Caddo peoples living in the upper Neches, and that their world views began to change after ca. A.D. 1480 (in sub-phase 2), but that these world views came to dominate beliefs and mortuary ritual usage after ca. A.D. 1560 and then continuing into the Allen phase (i.e., when Patton Engraved vessels have pigments rubbed in the design, it is almost always white). For example, at the late 17th-early 18th century Allen phase Deshazo site (41NA27), only white pigments ( $n=27$ sherds) were noted on the engraved fine wares (Fields 1995:187-197).

\section{Temper and Paste}

As with upper Neches River basin Caddo vessel ceramics in general (Perttula et al. 2011:Table 6-32), the mortuary vessels from these assemblages were predominantly tempered with grog, regardless of their age (Table 5). Grog is commonly the sole tempering inclusion, but more often than not, grog was the principal temper in conjunction with smaller amounts of crushed and burned bone and crushed and angular hematite/ferruginous sandstone pieces. Less than 5 percent of the vessels from any of the sites are tempered solely with aplastics other than grog. 
Table 5. Temper and paste in the vessels in these upper Neches River basin assemblages.

\begin{tabular}{|c|c|c|c|c|c|}
\hline Temper/paste & Local FW & $\begin{array}{r}\text { Non-local } \\
\text { FW }\end{array}$ & Local UW & $\begin{array}{l}\text { Plain } \\
\text { ware }\end{array}$ & $\mathrm{N}$ \\
\hline Bone & - & 2 & - & - & 2 \\
\hline Bone-grog & - & 2 & - & - & 2 \\
\hline Bone-grog-hematite & 1 & - & - & - & 1 \\
\hline $\begin{array}{l}\text { Bone-grog-hematite/ } \\
\text { fine sandy paste }\end{array}$ & 1 & - & - & - & 1 \\
\hline Bone-hematite & 2 & - & - & - & 2 \\
\hline Grog & 30 & 2 & 8 & 1 & 41 \\
\hline Grog/sandy paste & 1 & - & - & - & 1 \\
\hline Grog-hematite & 48 & - & 6 & 2 & 56 \\
\hline $\begin{array}{l}\text { Grog-hematite/ } \\
\text { fine sandy paste }\end{array}$ & 18 & 1 & 1 & 1 & 21 \\
\hline Hematite & 1 & - & - & - & 1 \\
\hline $\begin{array}{l}\text { Hematite/sandy } \\
\text { paste }\end{array}$ & 1 & - & - & - & 1 \\
\hline \multicolumn{6}{|l|}{ Summary Percent: } \\
\hline Bone & 3.9 & $\underline{57.1}$ & - & - & 6.2 \\
\hline Grog & 96.1 & $\overline{71.4}$ & $\underline{100.0}$ & $\underline{100.0}$ & 95.4 \\
\hline Hematite & $\underline{70.0}$ & 14.3 & 46.7 & 75.0 & 64.3 \\
\hline Sandy Paste & 20.4 & 14.3 & 6.7 & 25.0 & 18.6 \\
\hline Totals & 103 & 7 & 15 & 4 & 129 \\
\hline
\end{tabular}

FW=fine ware; UW=utility ware

In the larger regional vessel dataset (Perttula et al. 2011), the lowest frequency of grog temper (73.4 percent) in upper Neches River basin mortuary vessel assemblages is the group of vessels from the 14th to early 15 th century Lang Pasture site (41AN38). In the other sites, which all postdate A.D. 1400, grog is found in 93.7-100 percent of the vessels, affirming the predominant practice of employing grog or crushed sherds/fired clay as the temper of clear choice in the manufacture of pottery vessels. In the present sample of vessels, 95.4 percent are tempered with grog (see Table 5).

The use of bone temper is very common at a few sites, especially at the J. W. Blackburn (41CE4) and R. J. Fair (41CE25) sites. Both of these sites date to post-A.D. 1480-1560 contexts, and thus bone temper was a popular temper inclusion used during parts of the Frankston phase for vessels placed in burials. Overall, the frequency of bone-tempered pottery in the upper Neches River basin mortuary vessels ranges from 11.752.2 percent; our present sample of vessels has only 6.2 percent with bone temper (see Table 5).

The use of hematite temper in the mortuary vessels is also common in the upper Neches River basin, including our present vessel assemblage (see Table 5). No less than 33 percent of the vessels (from the 
Mrs. J. M. Cook site, 41AN1) from any one cemetery - and as much as 86.9 percent of the vessels (from the Fred McKee site, 41AN32) - had hematite inclusions in the paste (see Perttula et al. 2011:Table 6-32). The sites with the highest proportion of ceramics with hematite tempering are post-A.D. 1480 Caddo cemeteries. The lowest frequencies are in vessels from pre-A.D. 1480 sub-phase 1 Frankston phase cemeteries. These figures for hematite-tempered pottery represent very substantial use of hematite in upper Neches River Caddo mortuary ceramic contexts, and this use is well reflected in the present vessel assemblage.

No more than 22 percent of the vessels from any of the upper Neches River ceramic mortuary assemblages were made using a sandy clay paste (see Perttula et al. 2011:Table 6-32). In the present vessel assemblage, 18.6 percent have a sandy paste (see Table 5). Non-sandy clays were apparently preferred for mortuary vessel manufacture, highlighting the possibility that mortuary vessels were made in a distinctly different technological manner (or by a different potter than the ones that made vessels for domestic consumption) than vessels that were designed to be used by Caddo families for domestic activities, since they commonly were from vessels with a sandy paste.

The highest proportions of vessels in the present assemblage with grog temper, hematite temper, and a sandy paste are locally made wares (see Table 5). Non-local wares (all fine wares) are distinctive because they are characterized by the highest proportions of bone-tempered vessels.

\section{Firing Conditions}

These Upper Neches River Basin vessels were fired in a variety of different ways, presumably reflecting personal preferences in firing, the desired vessel color, the kind of clays that were used, and the functional and technological requirements of the kinds of vessel forms that were being manufactured for use at the sites. Vessels were likely fired in an open fire, with the vessels either set atop the fire or nestled in the coals and ash.

Locally made wares in the present vessel assemblage tend to have been fired in an oxidizing or high oxygen environment, especially the fine wares and plain wares (Table 6). Vessels fired in a reducing or low oxygen environment are found almost exclusively among the non-local fine wares. Substantial proportions of the locally-made fine wares and utility wares, as well as the non-local fine wares, were fired in a reducing environment but cooled in the open air.

Table 6. Firing conditions of the vessels in these upper Neches River basin assemblages.

\begin{tabular}{lrcccc}
\hline Firing Conditions & Local FW & Local UW & Local PW & Non-local & $\begin{array}{r}\text { Percent } \\
\text { FW }\end{array}$ \\
\hline Oxidizing (A) & $70.9^{*}$ & 46.7 & $\underline{\mathbf{1 0 0 . 0}}$ & - & 65.1 \\
Reducing (B) & 3.9 & 6.7 & - & $\underline{\mathbf{5 7 . 1}}$ & 7.0 \\
$\begin{array}{l}\text { Reducing, cooled } \\
\text { in open air (F-H) }\end{array}$ & 25.2 & 40.0 & - & $\underline{\mathbf{4 2 . 9}}$ & 27.1 \\
$\begin{array}{l}\text { Smudged/sooted (K) } \\
\text { Totals }\end{array}$ & - & $\underline{\mathbf{6 . 7}}$ & - & - & 0.8 \\
\hline
\end{tabular}

*percentage; $\mathrm{FW}=$ fine ware; $\mathrm{UW}=$ utility ware; $\mathrm{PW}=$ plain ware 
After ca. A.D. 1400, mortuary ceramics in the upper Neches River basin were very commonly fired in a high oxygen environment, or were incompletely oxidized instead. By site in the large regional vessel dataset, these two methods of firing comprise between 46.7-84.6 percent of all the vessels in the postA.D. 1400 detailed analysis sample (see Perttula et al. 2011:Table 6-33).

As a consequence of differences in firing, many of the vessels found in Caddo mortuary contexts in the upper Neches River basin have a reddish to reddish-brown color because of high oxygen firing, rather than the darker gray, grayish-brown, or black colors that would have resulted from firing in a reducing environment. However, firing vessels in a reducing environment, but cooling them in the open air (which includes 27.1 percent of the vessels in the present assemblage, see Table 6), would have had a similar effect, at least in terms of the color of the fired pots, since the open air cooling would leave a thin oxidized interior and/or exterior surface. Technologically, if the goal was to produce a vessel of a certain color and durability, it made more sense to fire the pot red-hot in an oxidizing fire, as the Frankston and Allen phase Caddo potters did, and thus they would have been able to see when a pottery vessel was done and could be removed from that fire, then it would be to gauge the right time to remove a pot from a firing when it was smothered in a bed of coals and ashes. This technological change or firing preference appears to have become part of the upper Neches River ceramic tradition - at least with respect to the manufacture of mortuary vessels - after ca. A.D. 1480 to A.D. 1560, during sub-phases 2 and 3 of the Frankston phase.

\section{Pinkware}

Approximately 9.3 percent of the vessels in these assemblages are "pinkware" vessels; this includes 25 percent of the vessels from the R. L. Jowell site (41AN13), 10.5 percent of the vessels at the Pierce Freeman site (41AN34), and 9.1 percent of the vessels at the Jim P. Allen site (41CE12) (Table 7). These pinkware vessels are vessels with a distinctive red to pink-colored paste after firing. These vessels were made with a clay with a moderate to high iron content (cf. Cordell 2001:17). Although the source of this clay is not known, we suspect it derives locally from iron-rich Weches Formation outcrops in the southwestern part of Smith County, the northwestern part of Cherokee County, and in northeastern Anderson County (see Bureau of Economic Geology 1965).

Table 7. Pinkware vessels in these upper Neches River basin assemblages.

\begin{tabular}{lll}
\hline Sites with pinkware vessels & No. of pinkware vessels & $\begin{array}{l}\text { Percent of } \\
\text { pinkware vessels }\end{array}$ \\
\hline Jowell & 4 & 25.0 \\
Emma Owens & - & - \\
Patton & 1 & 3.4 \\
Pierce Freeman & 2 & 10.5 \\
Hackney & - & - \\
Allen & 5 & 9.1 \\
Wallace & - & - \\
\hline Totals & 12 & 9.3 \\
\hline
\end{tabular}

Pinkware vessels and vessel sherds have been documented in a number of post-A.D. 1400 Caddo ceramic assemblages in the upper Neches River basin (Perttula et al. 2011:Figure 6-19), as well as a few sites downstream in the middle Neches River basin. In certain upper Neches River basin sites, pinkware 
is present in the sherd assemblages from the Isibel-Gene Donnell site (41AN14, 8 percent of the sherds), the Solon Stanley site (41CE3, 8.3 percent), Lang Pasture (41AN38, 7.8 percent), and the J. W. Blackburn (41CE4, 1.4 percent) sites.

A number of pinkware vessels have also been identified from prehistoric Frankston phase cemeteries in the upper Neches River basin. Approximately 11.2 percent of the 277 vessels analyzed in detail by Perttula et al. (2011) from the Mrs. J. M. Cook (41AN1), Mr. J. M. Cook (41AN2), Fred McKee (41AN32), J. W. Blackburn (41CE4), Omer and Otis Hood (41Ce14), E. W. Henry (41CE17), and R. J. Fair (41CE25) sites have the distinctive iron-rich pinkware paste. This iron-rich clay was used to manufacture both utility ware (i.e., Bullard Brushed and Killough Pinched) and fine ware vessels (Hood Engraved effigy vessels, Hume Engraved, and Poynor Engraved), as well as plain bottles and carinated bowls. Both fine ware and utility wares in the vessel assemblages discussed in this report are represented by pinkwares, including 6.8 percent of the fine wares (from Patton Engraved and Hood Engraved vessels) and 33.3 percent of the utility wares (Bullard Brushed, primarily). The highest proportion of pinkware vessels have been documented at the Fred McKee and J. W. Blackburn sites (Table 8), in contexts dating between ca. A.D. 1480-1650 (Frankston phase, subphases 2 and 3).

Table 8. Pinkware vessels from other Caddo sites in the upper Neches River basin.

\begin{tabular}{|c|c|c|c|}
\hline Site & $\begin{array}{l}\text { No. of } \\
\text { Vessels }\end{array}$ & $\begin{array}{r}\text { Proportion of } \\
\text { Pinkware } \\
\text { Vessels }(\%)\end{array}$ & Types Represented \\
\hline 41AN32 & 23 & 39.1 & $\begin{array}{l}\text { Plain bottle; Poynor Engraved, } \\
\text { var. P; Poynor Engraved, var. Freeman }(\mathrm{n}=2) \text {; } \\
\text { Poynor Plain; Poynor Engraved, var. Cook; } \\
\text { Brushed-punctated jar }(\mathrm{n}=2) ; \\
\text { Hume Engraved }\end{array}$ \\
\hline 41CE4 & 24 & 20.8 & $\begin{array}{l}\text { Poynor Engraved, var. Hood }(\mathrm{n}=2) ; \text { Hume } \\
\text { Engraved }(\mathrm{n}=2) ; \text { Hood Engraved }\end{array}$ \\
\hline 41AN1 & 33 & 12.1 & $\begin{array}{l}\text { Poynor Engraved, var. Lang; Hood Engraved; } \\
\text { Killough Pinched }(\mathrm{n}=2)\end{array}$ \\
\hline $41 \mathrm{AN} 2$ & 17 & 11.8 & Poynor Engraved, var. T; Bullard Brushed \\
\hline 41CE25 & 27 & 11.1 & $\begin{array}{l}\text { Poynor Engraved, var. Freeman; Poynor } \\
\text { Engraved, } \operatorname{var} . \operatorname{Hood}(\mathrm{n}=2)\end{array}$ \\
\hline 41CE17 & 35 & 8.6 & $\begin{array}{l}\text { Collared bottle; effigy vessel; Poynor } \\
\text { Engraved, var. } B\end{array}$ \\
\hline 41CE14 & 118 & 3.4 & $\begin{array}{l}\text { Poynor Engraved, var. K; Poynor Engraved, } \\
\text { var. Blackburn; Hood Engraved; Killough } \\
\text { Pinched; Poynor Engraved bottle }\end{array}$ \\
\hline
\end{tabular}

\section{Temporal Changes in Vessels}

Poynor Engraved is the principal fine ware in ca. A.D. 1400-1650 Caddo sites in the region. Seriation analysis of mortuary vessels from various Caddo sites in the upper Neches suggest that neither Hume Engraved or Patton Engraved pottery types began to be made until after ca. A.D. 1480 (in the case of Hume Engraved) or after ca. A.D. 1560 (in the case of Patton Engraved). Seriation analysis also suggests that Hood Engraved, var. Hood effigy vessels began to be made ca. A.D. 1400, they were most popular 
as mortuary offerings between ca. A.D. 1400-1480, and then they continued to be made and used through the Allen phase, especially Hood Engraved, var. Allen (tail rider effigy vessels). The frequency of Patton Engraved among the engraved fine wares (50 percent) from these sites suggest that they were used primarily as Caddo cemeteries near the end of the Frankston phase and in the post-A.D. 1650 Allen phase. In single component Allen phase cemeteries in the upper Neches, Patton Engraved vessels comprise almost 70 percent of the engraved carinated bowls (Perttula et al. 2011).

Patton Engraved is the youngest of the fine ware types in the upper Neches River, with Hume Engraved, Hood Engraved, and Poynor Engraved having begun to be made around ca. A.D. 1400 or so. Hume Engraved bottles are most common apparently in post-A.D. 1650 Allen phase contexts, while Poynor Engraved is primarily a Frankston phase (ca. A.D. 1400-1650) type, with a stylistic tradition that extends back some amount of time before A.D. 1400 and is also found on Caddo sites in the upper Neches that date after ca. A.D. 1650.

Hood Engraved, var. Hood is the earlier effigy form in the upper Neches (see Perttula et al. 2011:Table 6-37); one vessel of this type is in a burial at the Jim P. Allen site. Hood Engraved, var. Allen is found in association with Patton Engraved and other Allen phase ceramic types. This effigy vessel form includes zoomorphic or anthropomorphic tail riders. The other varieties of Hood Engraved have effigy heads and tab tails - as well as horizontal engraved lines as the main rim/body decoration - and are found in Frankston phase temporal contexts.

Hume Engraved, var. Allen and var. Hume are found primarily in Allen phase contexts or later (i.e., dating after ca. A.D. 1480) Frankston phase contexts. Hume Engraved bottles are absent from sub-phase 1 burials in the upper Neches (see Perttula et al. 2011:Table 6-37). Hume Engraved, var. Hume bottles occur only in burials from the Pierce Freeman and Jim P. Allen sites (see Table 3), while one Hume Engraved, var. Allen bottle is in a single burial at the Jim P. Allen site.

Based in particular on stylistic changes in the decoration of fine ware Patton Engraved and Poynor Engraved vessels in the upper Neches River basin, it appears that the cemeteries at the R. L. Jowell, Pierce Freeman, and Jim P. Allen sites may first have been used sometime between ca. A.D. 1480 to A.D. 1650, as marked by the occurrence of Poynor Engraved, var. Blackburn, var. Cook, and var. Hood (Perttula et al. 2011:Table 6-37). Varieties Hood, Cook, and Blackburn of Poynor Engraved comprise 75.8 percent of the sub-phase 2 Poynor Engraved vessels (but only 38.9 percent of the sub-phase 1 Poynor Engraved vessels) in the regional vessel dataset. Because Poynor Engraved, var. Freeman appears to be the latest variety of the Poynor Engraved type, making its appearance in sub-phase 3 of the Frankston phase (ca. A.D. 1560-1650), where it is the dominant defined variety, the common occurrence of var. Freeman in the Pierce Freeman and Jim P. Allen sites suggests that cemetery use was substantial at both sites during the latter part of the Frankston phase. The near absent of Patton Engraved vessels at the Pierce Freeman site (see Table 3) also suggests that this cemetery was likely abandoned by ca. A.D. 1650 .

In the case of Poynor Engraved, var. Freeman, the apparently simple stylistic decision to add concentric circles and hooked arm elements on the body (see Figure 3h-i) of carinated bowls, and then the addition of ticked marks to concentric circles on the vessel body (see Figure 5c), suggests a clear and not temporally lengthy stylistic link between Poynor Engraved, var. Freeman and Patton Engraved, var. Freeman. This stylistic relationship of concentric circle and hooked arm elements on vessel bodies, embellished by the later addition of ticks on those elements, further suggests that Patton Engraved, var. Freeman is the earliest of the defined Patton Engraved varieties. This variety of Patton Engraved is the dominant one at the Richard Patton site (41AN26), along with moderate amounts of var. Patton, var. Fair, and var. Allen (see Table 3), indicating the cemetery there was in use in the earlier part of the Allen 
phase. Increased frequencies of var. Patton at the R. L. Jowell cemetery suggests not only that this may be a slightly later variety of Patton Engraved, but that the R. L. Jowell site cemetery was in use after that of the Patton site; this may also be the case for the E. W. Hackney site, but there are not enough vessels in this cemetery assemblage to be temporally definitive. Finally, based on lower proportions of var. Freeman and var. Patton at the Jim P. Allen site (41CE12), but higher proportions of var. Allen and several still unspecified varieties (see Table 3), it is suspected that var. Allen is a later, and perhaps the latest, Patton Engraved variety, and that the Jim P. Allen site dates later in the $18^{\text {th }}$ century than the other Allen phase cemeteries in our present site sample. 


\section{References Cited}

Anderson, K. M., K. Gilmore, O. R. McCormick III, and E. P. Morenon

1974 Archaeological Investigations at Lake Palestine, Texas. Contributions in Anthropology No. 11.

Department of Anthropology, Southern Methodist University, Dallas.

Brown, J.A.

1996 The Spiro Ceremonial Center: The Archaeology of Arkansas Valley Caddoan Culture in Eastern Oklahoma. 2 Vols. Memoirs No. 29. Museum of Anthropology, The University of Michigan, Ann Arbor.

Bureau of Economic Geology

1965 Geologic Atlas of Texas: Tyler Sheet. Bureau of Economic Geology, The University of Texas at Austin.

Cole, N. M.

1975 Early Historic Caddoan Mortuary Practices in the Upper Neches Drainage, East Texas. Master's thesis, Department of Anthropology, The University of Texas at Austin.

Cordell, A. S.

2001 Continuity and Change in Apalachee Pottery Manufacture: A Technological Comparison of Apalachee-Style and Colono Ware Pottery from French Colonial Old Mobile and Mission San Luis de Talimali. Archaeological Monographs No. 9. Center for Archaeological Studies, University of South Alabama, Mobile.

Ferring, C. R. and T. K. Perttula

1987 Defining the Provenance of Red-Slipped Pottery from Texas and Oklahoma by Petrographic Methods. Journal of Archaeological Science 14:437-456.

Fields, R. C.

1995 Analysis of Native-Made Ceramics. In The Deshazo Site, Nacogdoches County. Texas, Volume 2: Artifacts of Native Manufacture, edited by D. A. Story, pp. 173-232. Studies in Archeology 21. Texas Archeological Research Laboratory The University of Texas at Austin.

Fields, R. C. and E. F. Gadus (editors)

2012 Archeology of the Nadaco Caddo: The View from the Pine Tree Mound Site (41HS15), Harrison County, Texas. 2 Vols. Reports of Investigations No. 164. Prewitt and Associates, Inc., Austin.

Gadus, E. F., R. C. Fields, J. K. McWilliams, J. Dockall, and M. C. Wilder

2006 National Register Testing of Seven Prehistoric Sites in the Sabine Mine's Area Q, Harrison County, Texas. Reports of Investigations No. 147. Prewitt \& Associates, Inc., Austin.

Gonzalez, B., R. Cast, T. K. Perttula, and B. Nelson

2005 A Rediscovering of Caddo Heritage: The W. T. Scott Collection at the American Museum of Natural History and Other Caddo Collections from Arkansas and Louisiana. Historic Preservation Program, Caddo Nation of Oklahoma, Binger, Oklahoma. 
Jackson, A. T.

1932 Notes on Work Done-Cherokee County, Texas Conducted by A. T. Jackson and crew, R. F. Wallace Farm (Lee Hudson Place). MS on file, Texas Archeological Research Laboratory, The University of Texas at Austin.

Jelks, E. B.

1965 The Archeology of McGee Bend Reservoir. Ph.D. dissertation, Department of Anthropology, The University of Texas at Austin.

Jones, B. C.

1968 The Kinsloe Focus: A Study of Seven Historic Caddoan Sites in Northeast Texas. Master's thesis, Department of Anthropology, University of Oklahoma, Norman.

Kleinschmidt, U. K. W.

1982 Review and Analysis of the A. C. Saunders Site, 41 AN19, Anderson County, Texas. Master's thesis, Department of Anthropology, The University of Texas at Austin.

Lankford, G. E.

1992 Red and White: Some Reflections on Southern Symbolism. Southern Folklore 50(1):53-80.

Marceaux, P. S.

2011 The Archaeology and Ethnohistory of the Hasinai Caddo: Material Culture and the Course of European Contact. Ph.D. dissertation, Department of Anthropology, The University of Texas at Austin.

Marceaux, P. S. and T. K. Perttula

2010 Negotiating Borders: The Southern Caddo and Their Relationships with Colonial Governments in East Texas. In American Indians and the Market Economy, 1775-1850, edited by L. Greene and M. R. Plane, pp. 80-97. University of Alabama Press, Tuscaloosa.

Marceaux, P. S. and M. F. Wade

2014 Missions Untenable: Experiences of the Hasinai Caddo and the Spanish in East Texas. In Indigenous Landscapes and Spanish Missions: New Perspectives from Archaeology and Ethnohistory, edited by L. M. Panich and T. D. Schneider, pp. 57-75. University of Arizona Press, Tucson.

Middlebrook, T.

1994 An Update of Archaeological Investigations at the Tyson Site. Journal of Northeast Texas Archaeology 3:1-36.

Perttula, T. K.

2007 Kinsloe Focus Artifact Assemblages and Nadaco Caddo. Journal of Northeast Texas Archaeology 26:116-119.

2008 Trends and Varieties in Late Caddo and Historic Caddo Fine Ware Pottery Types in the Upper Neches River Basin. Journal of Northeast Texas Archaeology 28:51-55.

2014 Archaeological Studies of the Hatchel Site (41BW3) on the Red River in Bowie County, Texas. Special Publication No. 23. Friends of Northeast Texas Archaeology, Austin and Pittsburg. 
Perttula, T. K. and T. Middlebrook

2008 Prehistoric Caddo Ceramics from the Henry Lake Site (41CE324), Cherokee County, Texas. Journal of Northeast Texas Archaeology 29:9-21.

Perttula, T. K. and B. Nelson

2014 The Millsey Williamson (41RK3), Bead Burial, and L. N. Morwell Farm Sites on Martin Creek: Historic Caddo Settlements along Trammels Trace, Rusk County, Texas. Journal of Northeast Texas Archaeology 44:23-46.

Perttula, T. K., D. B. Kelley, and R. A. Ricklis (assemblers and editors)

2011 Archeological Investigations at the Lang Pasture Site (41AN38) in the Upper Neches River Basin of East Texas. Report No. 129. Texas Department of Transportation, Archeological Studies Program, Environmental Affairs Division, Austin.

Perttula, T. K., B. Nelson, R. L. Cast, and B. Gonzalez

2010 The Clements Site (41CS25): A Late 17th to Early 18th-Century Nasoni Caddo Settlement and Cemetery. Anthropological Papers No. 92. American Museum of Natural History, New York.

Perttula, T. K., B. Nelson, and R. Z. Selden Jr.

2013 Documentation of Cemeteries and Funerary Offerings from Sites in the Upper Neches River Basin, Anderson, Cherokee, and Smith Counties, Texas. Special Publication No. 26. Friends of Northeast Texas Archaeology, Pittsburg and Austin.

Rice, P. M.

1987 Pottery Analysis: A Sourcebook. University of Chicago Press, Chicago.

Skibo, J. M.

1992 Pottery Function: A Use-Alteration Perspective. Plenum Press, New York.

Story, D. A. (editor)

1982 The Deshazo Site, Nacogdoches County, Texas, Vol. 1. Texas Antiquities Permit Series No. 7. Texas Antiquities Committee, Austin.

Suhm, D. A. and E. B. Jelks (editor)

1962 Handbook of Texas Archeology: Type Descriptions. Special Publication No. 1, Texas Archeological Society, and Bulletin No. 4, Texas Memorial Museum, Austin.

Teltser, P. A.

1993 An Analytic Strategy for Studying Assemblage-Scale Ceramic Variation: A Case Study from Southeast Missouri. American Antiquity 58(3):530-543.

Woolsey, A. M.

1935a Notes on Field Work, E. W. Hackney Farm, 9 Miles Northwest of Jacksonville, Cherokee County, November 16 to November 19, 1935. MS on file, Texas Archeological Research Laboratory, The University of Texas at Austin.

1935b Notes on Field Work, Jim P. Allen Farm 7 1/2 Miles Northwest of Jacksonville, Cherokee County, October 19-November 4, 1935. MS on file, Texas Archeological Research Laboratory, The University of Texas at Austin. 
